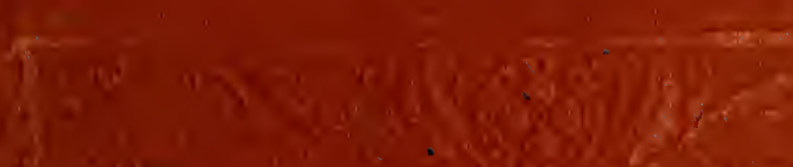

(x) $=19$

$-9$

. $a^{x}$

$-\ln ^{2}+x^{2}$

- $2=1 \%=$
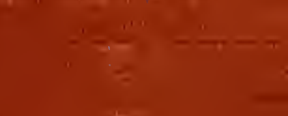

$=$

a

s.

8

$=50$
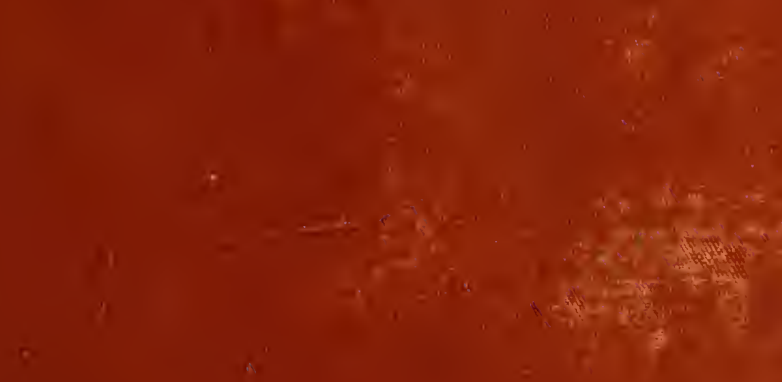

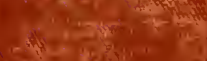

$x_{x} \quad$ in $=>-7$

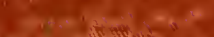

i2 6 and को 8

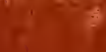

4

$x=2$

cer

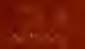

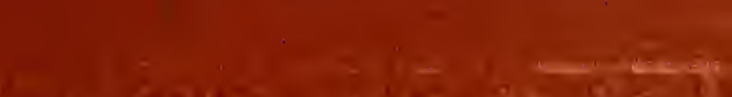




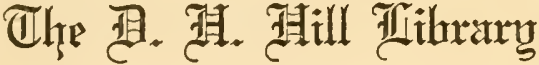

Xarth Uaralina State Uallege

$$
\begin{gathered}
\text { SB416 } \\
\text { T3 }
\end{gathered}
$$

$$
\therefore \therefore
$$


Horticultural Difartment. 
Digitized by the Internet Archive in 2009 with funding from NCSU Libraries 


\section{Greenhouse Construction}

A COMPLETE MANUAL

ON THE

Building, Heating, Ventilating and Arrangement $\mathrm{OF}$

\section{GREENHOUSES}

A

Construction of Hotbeds, Frames and Plant Pits

BY

L. R. TAF'?

Professor of Horticulture and Landscape liardening, Hichigun Aym cullural colle'go

ILLUSTRATED

NEW YORK

ORANGE JUDD COMPANY

1894 


$$
\text { Corytight, 1893, }
$$

JY ORANFE JUDD COMPANY 


\section{PREFACE.}

In the summer of 1889 the writer arected two forcing houses for the Michigan State Experiment Station. They were designed to be experimental in their construction, and afforded means for a comparative test of various methods of Duilding, glazing and ventilating, and of the relative merits of steam and hot water for greenhouse heating. When the houses hal been used one season, a bulletin was issued, in which the construction was described, and the merits or demerits of the methods used were pointed ont. During the winter a test of the heating systems was made, and the results were given in the same bulletin. The report was widely distributed, and was copied in full by mamy horticnltural and engineering periodicals, while others gave it favorable notices, which led hundreds of prospective builders of greenhonses, in all parts of the country, to apply for copies, and made a second edition necessiry. From nearly every State in the Union came letters, asking advice upon varions points in greenhonse construction and heating, all of which indicated, not only that there was a widespread desire for information on these subjects, but that the sources of information were quite limiter.

At the request of the publishers, the preparation of this book was undertaken, and the attempt has been made to present the best methods of greenhouse construction.

Although with fifteen years' experience in greenhouse management and a large experience in greenhouse 
constunction, all of which has been in eonnection with the agricultural colleges of various states, where there was an exeellent opportunity of testing the different wrinkles in eonstruction that have been, from time to time, Jronght ont, the writer has arailed himself of varions opportunities, during the past three years, to visit the leading floral and regetable growing establishments of more than a dozen large eities, between Boston and St. Louis, and has marle a carefnl study of the methods employed. Many of the leading florists have submitted their ileas, either in personal interviews or by eorlespondence, and from the pages of the American Gardeming. American Florisl, Gardening, American Agricullurist, and other periodicals, much useful information has been obtained.

Some of the firms that are engaged in the building and heating of greenhouses have been in business for many rears, and lave hal a wide experjenee. From them, ton, many valuable points have been received, and it is to their kindness that we are indebted for the illustrations of the exteriors and interiors of some of the most noted homses in the comntry.

'The information here presented has, thercfore, come to us from a variety of reliable sonrees, and, instead of being the anthor, the writer ean only claim to be the editor of this collaborative book.

With the multitude of persons who have aided us in its preparative, it is impossible to render acknowledgment to them individually, but to each and all are extended the hearty thanks of

$$
\text { L. R. 'TAFT'. }
$$

Mariculitural College, Mich. 


\section{CONTENTS.}

Preface, . . . . . . . . . . iii

CHAPTER I.

HISTORY OF GREENHOUSES, . . • . . . I I

CHAPTER II.

DIFFEREXT FOINS OF GREENIOUSTS-EVEN SPAN, LEAN-TO,

SIDE-HIILL, 。

CHAPTER III.

THREE-QUARTER SPAN IIOUSES, .

CIIAPTER IV.

LOCATION AND ARIRANGEMENT,

CHAI'TEIR V.

GRENIOUSE WALLS,

CHAPTER VI.

CONSTRLCTION OF THE ROOF,

CIIAP'TER VII.

COMBINED WOOD AND IRON CONSTIUCTION,

CHAP'TER VIII.

IROX HOCSES,

CIIAPTER TX.

The Pitch of the Roof, .

CIIAP'TER $\mathrm{X}$.

Glass AND GLAZING, .

CHAP'TEI XI.

GLAZING-METHODS AND MATERIALS,

CHAI'TEIR XII.

VENTILATORS

CHAPTER XIII.

Greenhouse Bexches, CHAT'TER NIT.

Paintiyg AND SHadiNg, . . . . . . 85

CIIAPTER XV.

GreeyHoUse HeATHY,

CIIAPTER XVI.

Pipes AND PIPING, 
CHAPTER XVII.

Size AND Amount of Piping, . . . . . . 104 CHAPTER IVIII.

HOT WATER HEATERS,

CIIAPTER XIX.

STEAM IIEATINF, .

\section{CIIAP'TER XI.}

123

COMIARATIVE MERITS OF STHAM AND HOT WATEl, . . 129 rIIAT'TER XXE.

HEATING: SMALL CONSERVITOLIES, . . $\quad \cdots \quad$. . 134

CIIAT'TER XXII.

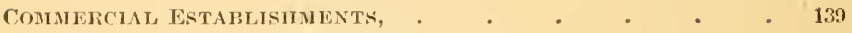

CIAPTER XXII.

Rose IIOUSES, .

CHAPTER XXIV.

LETTUCE HOUSES, CIIAPTER XXV.

PROPAGATING IIOUSE, CIIAPTER XXVI.

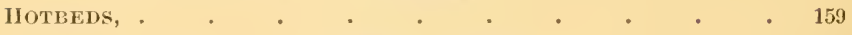

CHAPTER XXVII.

CONSEIVATORIES, CHATTER IXVIII.

THE ARTANGEMENT OF GREENHOLSE, - • • • . 185 CHATTER XXIX.

Glass Structures for AMATEUrs, . . . . . 195 


\section{LIST OF ILLUSTRATIONS.}

Fig. 1. English Greenlouse of 17th Century

2. First Ameriean Greenlionse,

3. Model fireenliouse of $\mathbf{1 8 3 5}$,

4. First Chicago Greenlouse,

5. Hven Spin Greenhouse,

6. Rirlge and Furrow Houses,

7. Leau-to llouse,

8. Side-llill Houses.

9. 'Three-Quarter'sinan ifonse,

10. Curvilinear llouse,

11. Grout Wall,

12. Grout and Worlen Vrail,

13. Brick Wall with Woodell sill,

14. Briek Wall witl trousill, .

15. Woolen Wall,

16. Wooden Will with Glass Sicle,

17. Iron Post aud sill 31

18. Sash Bar with Drip Gutters, . . . . . 34

19. Plain Saslı Bar, . . 34

20, 21,22. Sish bars for Butten Giass, . . . . 34

23. l'lain Sash biur for Bntted Glass, • • • 35

24. Greenhouse with l'ortable lisof, • • 36

25. Elevation and Jetails for Wooden Roof, . . 39

26. Details for Iron and Wood Roof, 41

27. Gas l'ipe l'urlill. 42

28. Iron Bracket for Roof, . . . . . . 42

29. Iron Posts aud Braces, 43

30,31. Helliwell Patent Glazing, . . . . . . 46

32. L'aradign Glazing, . . . . 47

33, 34. Galvanized Iron Sasl Jars, . . . . . . 48

35. Effeet of Glass at Different Augles, . . . 50

36. Short Span to the South Houses, 54

37. Glazing l'oints, . . . . . . 61

38. Patilt Fisll, . . . . . . fit

39. Ives' lintity Machine, . . . . . . 65

40. Trasser"s (ilazing Strip, . . . . . . 65

41. New Methocls of Gilizing, . . . . . . 66

42. Arrangement of Ventilitors, . . . . . 68

43. A Simple Ventilating Apparatus, . . . . 70

44. New leparture Venfilating Apparatus, . . . 71

45. Standarl Ventjlating Appiratus, . . . . 72

46. Challenge Ventilating Mashine, . . . . 73

47. A Clieap Fixture, . . . . . . 74

48. Outside Shafting, . . . . . . . . 75

49. Wooden Benches, 77

50. Gas Pipe Bencli Suppoits, . . . . . 78

51. Mendenliall's Bencli, . . . . . 79

52. Hill's Bench, . . . . . . 80

53. Angle Iron Beriek, . . . . . . 81 
54. Benel, Tiles, . . . . . . 82

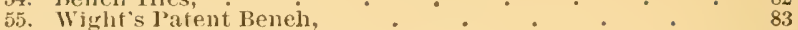

56. Woot and Slate Bench, . . . . . . . . . 84

57. 'ilic: Slope of the Pipes, . . . . . . 100

58. lindre liench l’iping (wide house), . • . . . 106

59. Juster Bench Pijoing (narrow lonse), . . . 107

60. Overliead Piping (short span to flue sontil honse), . . 108

61. Combined Overheat and Unker lieneb Piping, . 109

62. Combined I'iphing for Evenspan House, . . . 110

63. (ombinter Piping for Forcing llouse, . . . 111

64. Ariagement of the Coils, . . . . 112

65. Carmokly Hot. Waler lleater, . . . . . . 115

66. llitehings' Ileatter, . . . . . . . . 116

67. Weathered's Conjeal IIeater, . . . . . 116

$68,69,70$. Spenee IIeater, . . . . . . . 117

71. Furman Portable Heater, . . . . . . . 119

72. Finfman Brick Set Ileater, . . . 120

73. Hitehings' Batse lintuing Ieater, . . . . 12I

74. Inferior of Steam Heafed House, . . . . . . 127

75. Hatrald Heater, . . . . . . . 136

76. I'lan for a Small Eslablishment, . . . . 140

77. Moclern Rose Houses (woml), . . . . . . 144

78. Extensive Rose Houses (iror), . . . . . . 145

79. Fromal Plan of A bove, . . . . . . . 147

80. Seetion of Ilun Rose llonse, . . . . . . . . . 148

81. Interior of Ruse llouse (iruli), . . . . . . 150

82. Section of Rose House (wourl), . . . . . . 151

83. Section of Lean-to Lettnee llotise, . . . 155

84. Hotbed Frame, . . . . . . 159

85. Hoiherl with Sash, . $\quad . \quad \ldots \quad$. $\quad . \quad 160$

86. Hotherl Slunter, . . . . . . . . . . . 161

87. Hotsed Yarcl, . . . . . . . . . . 162

88. Coll l'it, . . . . . . . . . . . 164

89. 1arge Attaeherl Conservatory, . . . . . . 167

90. Moitin Detachen Conservatory, . . . . . . 169

91. Comservatory (section), . . . . . 170

92. Interior of Conservatory, . . . . . . . 171

93. I'alm IIouse of Pitelier it Manta, . . . . . 173

94. Slove Roons (section), . . . . . 174

95. Combined stove and (orehid llonise, . . . . 175

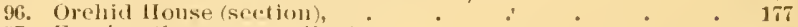

97. Foreing irapery (sectiun), . . . . . . . . 179

98. Even van trajery (section), . . . . . 180

99. (Grvilinear Grapery (seetion), . . . . 181

100. Greenliouses of Michigan Agricultural College, . $\quad 186$

101. Gromnkl l'lan of Same. . . . . . . . . 187

102. Rasge of Houses by Weathered, . . . . . . . . 188

103. liange of llouses by 11itehings, . . . . . . 190

104. Frounk Plan of Hitelings Riluge, . . . . . . 191

105. Range by Lorr \& linrulian Co., . . . . . 192

106. Fromind Plan of Above, . . . . . . . . . 193

107. Foreing Honse (section), . . . . . . . . . . 194

108. Rose House (section), . . . . . . . . 194

109. Veranda Conservatory, . . . . . . . 196

1i0. Veranda Conservatory (seetion), . . . . . 197

111. Small Attached C'onservatory, . . . . 199

112. A Cheap Honse, . . . . . . . . 200

113. Portable Conservatory, . . . . . . • • 202

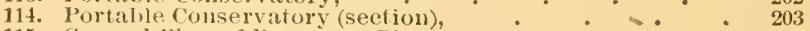

115. Fround l'lan of liaseninent Pit, . . . . • 204

116. Details for liasement l’it, . . . . . . . 205

117. Cellarway Conservalory, . . . . . • • 206

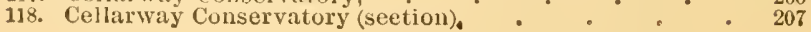




\section{GREENHOUSE CONSTRUCTION.}

\section{CHAP'TER 1 .}

\section{HISTORY OF GREENIICUSES.}

It is known that the old Romans were able to secnre fresh fruits and regetables, for their banquets, the rear romd, by both retarling and accelerating their growth. As an indication of their skill, it is said that they eren forced the cncmmber. They possessed no elaborate structures for this purpose, lunt grew them in pits covered with large slabs of tale. Heat was obtained from decomposing manure, and ly means of hot air fines. They are believed to have had peach and grape houses, and it is claimed liy some, that hot water in bronze pipes was used to warm them.

In modern times the structures have nndergone a gradual derelopment, from honses containing no gliss whaterer, to the forcing honse of to-day, which is nearly ninety-five per cent. of glass. The first house of which we have any record, was built by Solomon de Cims, at IIeidelberg, Germany, abont 1619. It was nsed to shelter orer four hundred orange trees planted in the gronnd, during the winter, and consisted of wooden shntters placed orer a spun roof framework, so as to form the walls and roof. It was warmed by means of fonr large furnaces, and rentilated by opening small shutters in the sides and roof. In the spring the framework was taken down. 'This structure, in size, com-

\section{1


pared well with the greenhonses of to-rlar, as it was two lomdred and eighty feet long and thirty-two feet wide. On account of the expense of putting up and taking down this framework, and of keepung it in repair, it was replaced by a structure of frestone. 'This had an (oparye roof, and the openings in the silles were closed with shntters during the winter. In $168 \pm$ Riy describes a glass house (Fig. 1) nserl in the Apotheearies Garden.

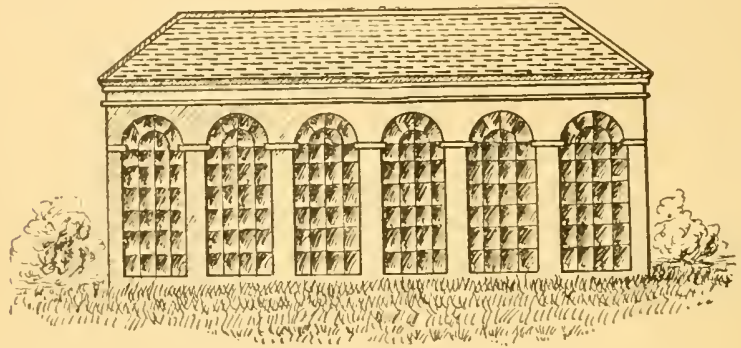

FIC. 1. ENGLISH GREENIOTSE OF 1\%TI CENTURY.

Chelsen, England, which evidently was quite similar to the one at Heidelberg, except that it had glass windows in the side walls; the roof, however, was oparue. It was not nutıl $1 \% 1 \%$ that grass roofs were nser, and from that time, for one hundred years, few improvements were male.

During the first part of the present coutury considerable attention was given to the slope of the roof, and in 181 , the hemispherical form was first nsed. Before the use of glass for the roof hecame common, the greenhouses often ocempied the first floor of two-story structures, while the second floor was occupied by the gardener as a residence, or was nsed as a storeroom.

The callice greenhouses of this comntry were not unlike those used in Enrope during the eighteenth cen- 
tury. In the American Flomst for Feb. 15, 1s8\%, is the description and figure of what is supposer to be the

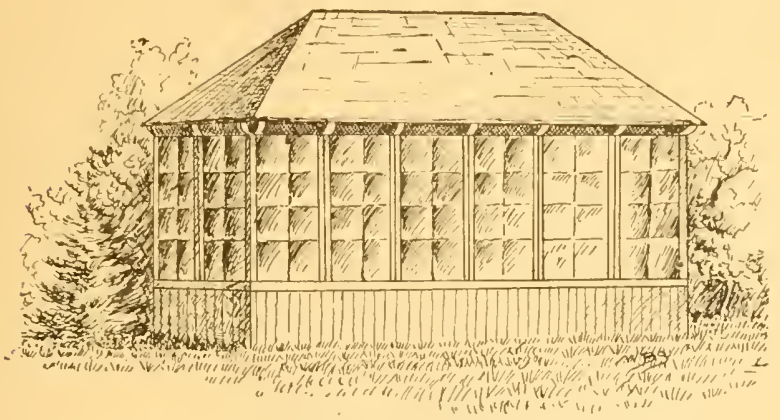

FIG. 2. FIRST AIERICAN GREENIIOUSE.

first Ameriean meenhonse (Fig, 2), it having heen erected in New York, in 1\%64, for James Buekman. Athough the structures were less elaborate, the Imerican buldiers took up and ntilized any improvements in construction and heating that were bronght ont in Enrope.

In Hovey's Majasine of Horticulture, for .January

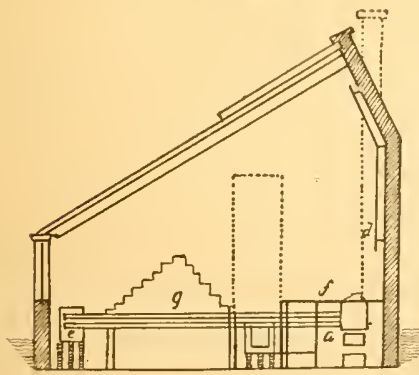
1836, is a description of a model greenhouse, erected by Mr. Sweetser, of Cambrudgeport, Mass. From Fig 3, in which a cross sec. tion is shown, it will be seen that glass was used 111 the enture south slope of the roof and in the south wall. The north slope of FIT. 3. MODEL GREENHOLSE the roof and the nolth wall OF 18.3 .5 . were of wood. The lieat. ing system combined the flue with hot water. The hot 
water system consisted of an open copper kettle, or heiter $(f)$. from the top of whrch a four-inch copper pipe passed across the end of the house, and then along the opposite side, to a large copluer reservor $(e)$; the return pipe was loeated on a lerel, just beneath the flow, cutering the bonler near the bottom. The flue was carried to one side mutil it reached the walk $(r)$, md then lim muder this to the other end of the house, where it was connected with the chimmey $(d)$.

In the Nest, greenhouse construction was more backward, and yet, as early as 18:36, a Mr. Thomas,

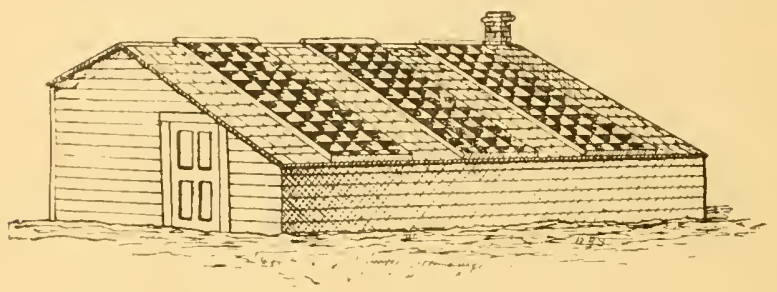

FIG, 4. FIRST CIILAGO GREENAOLSE.

according to the Amerucun Flortst, elected one in Chieago, of which an illustration is shown in Fig. 4. $\Lambda$ s will be seen from the engraring, the three-quarter span honses hat even then come into use, although the entire morth slope, and half of the south slope of the roof, were of wood.

Previons to 1850 there were comparatively few greenhouses in the eomtry, and, naturally, there were no extensive builders. Among the first to engage in the business was Frederic A. Loid, who ereeted his first houses in Buffalo, in 1855. In $18 \% 0$ he removed to Irrugton, and in $18 \%$ : entered into partnership with II. A. Burnham, moder the firm name of Lord $\mathbb{x}$ Burnham. In 1853 the firm of Lord \& Burnham Co. was 
incorporated. The earlier houses erected hy this firm were, for the most part, in the curvilinear style, which, in a slightly modified form, is still used by them for large conservatories.

In 1885 the firms of Hitchings \& Co., and of Thos. IV. Weathered's Sons, both of New York City, who for many rears bad been engaged in greenhouse heatung, added departments for greenhonse construction. John C. Moninger, of Chicago, is one of the best known bulders in the ITest. The srstems of construction used by the three first mentioned firms are much alike, therr better houses being put up with iron sills, posts, rifters, purlins, ete., while the sash bars are of eypress, although many of their commercial establishments have no iron in theil construction.

'The puttyloas glazing systems have heen but little ased, except in large conservatories. The principal firms controlling them are the Plenty IIortienltural IVorks of New York City, and A. Elgecomb Rentle \& ( o. of Philadelphia and Chicago, each of whom have been in business for some ten yeirs, and have erected a number of large establishments. They also use the wooden sush bars and putty grazing. Nearly every large eity has one or more dealers in structural iron work, who have taken up greenhouse construction. Most of them use galranized iron, with or without a steel core, for sash bars. The use of iron for the rafters and sish bars of fixed roofs, has been quite general in England for eighty years, as its permanency is there thought to more than counterbalance the extria expense, breakige of glass, loss of heat, drip and leakage, with this system, as compared with wooden supports. In this country the winters are much more serere, and, the conditious being less farorable for iron roofs, their use is not regarded with faror by commercial florists.

Te have no description of the furnaces used by Dr. Caus, in his orangery, but Erelyn tells us thit the Chel. 
sea greenhouse wats heated by an open charcoal fire built 111 a hole in the gromud. Later ou, al chimney was carred through the greenhanse, and this developed into the greenhouse flue, which is still in use. Although stemn Wis tried for heating greenhouses, in the last quarter of the eighteenth century, it was not much used until about 1816, when, for twenty years, it was in high faror, but was superseded by hot witer, which, in turu, has, during the last few years, been erowded out, in large plants, by steam.

\section{CHAPTER II.}

DIFFERENT FORMS OF GREENHOUSES.

While the various glass structures are generally distingnished according to their uses, as rose houses, palm houses, stove hourses, graperies, ete., for our present purpose it will be well to first consider them from the builder's' standpoint, as lean-to, span roof, three-quarter span, and curvilinear houses. These names have been applied from the various shapes that may be given to the houses. While any of these forms of houses may be used for all purposes, each one of them is particnlarly adapted for the growing of certain plants, and as they each have their special advantages and dis:udvantages, they should have careful consideration.

\section{SPAN ROOF HOLSES.}

"ithe form of glass structure which has come to be known as the span roof is, more properly, the "uren span," as the lean-to may be considered a "half span" homse, while we also have "tro-third" and "threequarter span" honses. The typical "even span" house 
is generally from nine to twelve, or from eighteen to twenty feet wille, with side walls from four to five feet high. The two slopes of the roof are of the same extent, and are arranged at the same angle, usually between thirty and thirty-five degrees, which will bring the ridge, in a house twenty feet wirle, about ten feet above the walk, in a house with walls four feet high, and the roof at an angle of thirty degrees, and eleven feet high, when it has a slope of thirty-fire degrees.

In a house of this size, it is desirable to have, at least, two rows of rentilating sish, which may be on either side of the ridge, or, if three rows are used, one

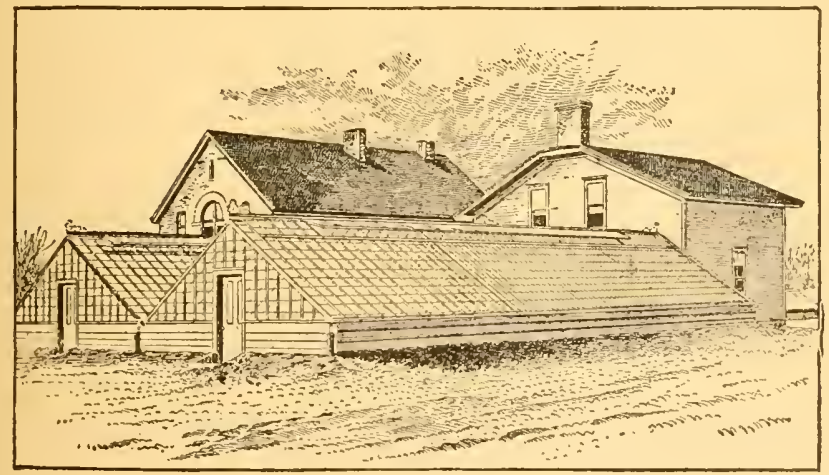

FIG. 5. ETEN SPAN GREENHOUSES.

may be located at the ridge and the others in the side walls. The amount of ventilation desirable will, of conrse, be determined largely by the plants to be grown in the house.

Although less simple in construction than the lean-to, they hare a far greater variety of uses, and are much more frequently erected. In fact, nearly all the houses construeted for commercial purposes, prior to 1885 , were of what is known as the eren span style (Fig. j). 
For ordinary growing honses for a commercial florist, this form is as good as can be seenred, although for forcing houses the three-puarter span is preferable. One of the special adruntinges of these houses is that they nay be run at almost any direction that the location may necessitate. With this form of roof, the benehes cin be placed at the same height, and the plants will still be near the glass. while in other forms of roof, with the same pitch, the rirlge will be much higher.

The even span houses are usnally run north and sonth, as this not only brings the plants, on both sides of the honses, into full sunshine diring a part of the day, but better than any other direction. or any other kind of a house, provides for a perfect distribution of the rays of light and heat npon all sides of the plants. For many purposes the east and west arrangement, with one side faeing the sonth, is preferable, as, during the four hours of the day when the sun's rays are most powerful, they strike at right angles to the glass, and are but little obstructed ly the sash bars: while, were the houses running north and south, more than half the rays would be eut off between eleven and one o'elock, and, as this part of the day is particnlarly valuable in the forcing house, this arrangement is preferable for them. The beneficial effects, however, will be confined to about two-thirds of the lionse, on the side towards the sun, while the other side will have mueh less sun than were it in a house running north and sontl. If designed as growing houses, this might not be objectionable, as the north side conld be used for ferns, violets, or for plants at rest, which do fully as well in partial shade.

The fact that the north third of the house is of little valne for forcing purposes, led, in part, to the eonstruction of the first forms of two-third and three-quarter span houses, which, so far as the slope of the roof is 
concerned, did not differ from the even span, the only difference being that the back wall was run up at a point which cut off the north third or fourth of the house. Fverything else being equal, the loss of heat from a span roof house will be somewhat greater than from either a lean-to, or mneven span house, especially if it, like the others, runs east and west, on account of its haring a greater area of glass upon its north side. In the lean-to there is no glass at all on the north side, while, in the three-quarter span honse, the glass area on the north side will only be one-half as great as in the even span.

'The even span houses maty vary in wirlth, flom nine to twenty-four feet ontside. For the narrow houses only one walk, situated in the center, with a bench on each side (See lig. 59), is used. When the walk is two feet wide there will be room for two tables, each three and one-lualf feet in width. These widths may be increased to four feet for the beds, and two feet six inches for the walk, if necessary, but twelve feet would be the extreme width that could be used with comfort, when a house with a single walk is to be used for most greenhouse crops, especially if they are grown in pots. When two walks are used, the louses would need to be increased to a width of, at least, sixteen feet, and, for some purposes, may be as 11 nch as twenty-foul feet, which will be as wide as will probably be used under any circumstances. A medium width, howerer, is preferable, and the greatest conomy of space and comfort, in caring for the honses, will be obtained, when the houses are not less than eighteen feet, nor more than twenty, ontside measurement.

While honses are often built with walks as narrow as eighteen inches, it is better to allow two fect, in commercial growing houses, and in private houses a willth of two and one-half feet for walks, will not be too great. For the side benches, three feet and six inches will be 

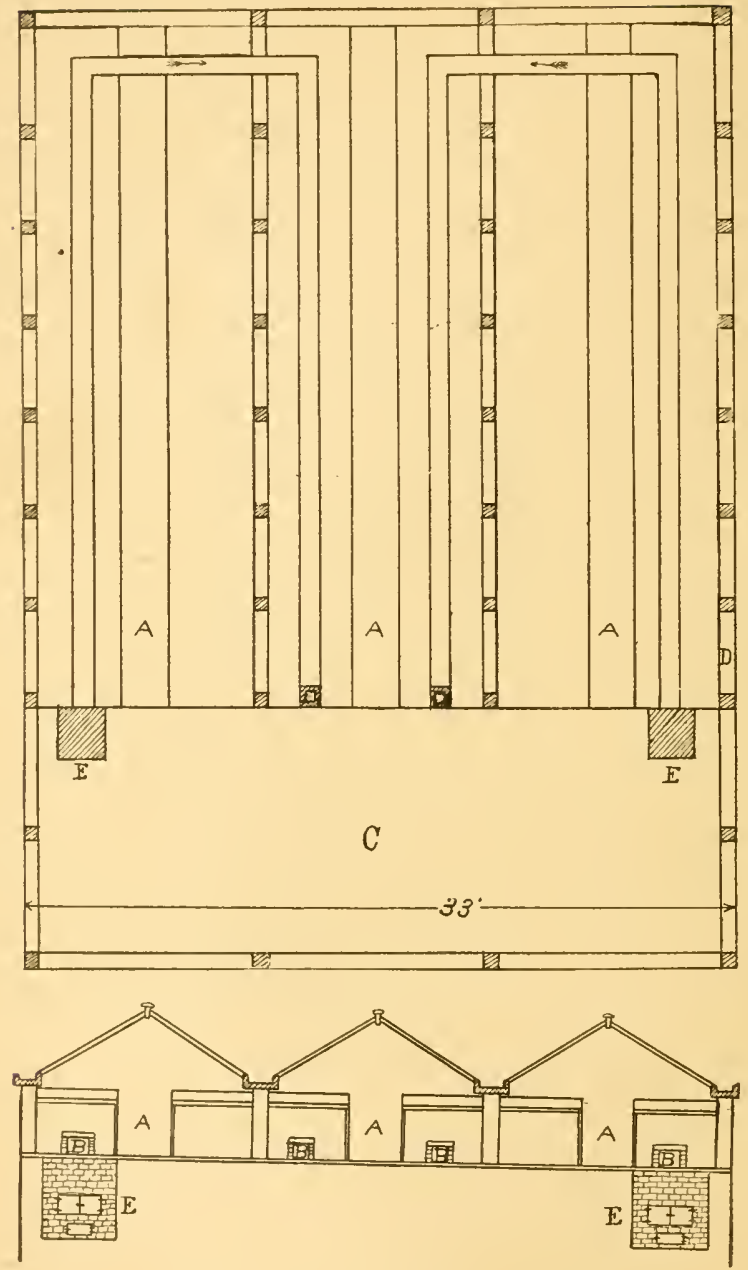

FIG. 6. GROUND PLAN AND END ELEVATION OF RIDGE AND FURIOW HOUSES. 
found a conrenient width, although four feet is often used. If the greatest economy of space and convenience of handling the plants is songht, the center bench shonld be abont seren fect in wilth. 'I'hey are, howerer, often made as narrow as six feet, and when large plants are to be grown, which will make a high roof desirable, the width of the house may be increased to take in a bench ten or eleven feet in willth.

\section{RIDGE IND FERLOW HOLSES.}

The even span form of roof has one adrantage that is possessed by no other (except by the short span to the south, or the three-quarter span on a sidehill), as they admit of the ridge and furrow constrnction, as it is commonly called. 'This should, howerer, be distinguished from the ridge and furrow form used in Englanel by sir Joseph Paxton and others, in which the roof was broken up into a great number of ridges, and furrows run up the main slope of the roof.

The principal gain is due to the fact, as shown in Fig. 6. that wheir. say fire, homses are built in this war, only six walls will be requirecl, and four of these can be of light, cheap construction, insteald of the ten well-built walls that would be necessary were the houscs built separately. Another adrantage. which should not be overlooked, is due to the fact that there will be only onefifth as much exposed wall surface, and that, when built thus close together, one house on each side will protect the others from the high, cold winds that come from that direction. There will also be a considerable saring in space, which will be worth considerable, especially in cities.

Among the disadrantages of the ridge and furrow style of houses, is the shading of the center houses during the morning and afternom, by those on either side, ly which, especially in the casce of wide, light houses, 
much light and heat is shut off; also the fact that when honses are built in this way, side light and side ventilation cannot be secured. While this is not even desirable for some erops, for other's it is rnite necessary, and whether crops are to be selected that are adapted to the houses, or houses are to be ereeted that are to be suited to the growing of eertain erops, this should be understood.

It may be laid down as a rule that, aside from the ceonomy of erection, heating, etc., better results will be obtained from wide houses, if they are built with intervalls of, at least, fifteen feet between them; but when the crection of the extra walls, and the increase in fuel and land are considered, for the ordinary florist, even span honses, of a width of twenty feet or less, should be erected upon this plan, mnless other special reasons might exist. In sections where the snowfall is heary, the gutters will become filled, and, as the snow cannot slide from the roof, with long houses, unless they are narrow, and only buitt with three houses in a section, to allow of the snow being thrown over the roofs of the side houses, this will be a serions objection to the plan. For the growing of small bedding plants, mignonette, heliotrope, calruations, and for propagating honses, this form of construction, with houses twelve feet wide, will he quite satisfactory. Of conrse, any plants can be grown in them, but a wider house seems preferable for roses, carnations, lettuce, and for most forcing crops, particularly as the amount of air enclosed is greater in proportion to the amount of exposed glass surface, on which aceount the temperature can be easier regulated, and drafts of air prevented.

\section{TIE LEA N-TO HOUSE.}

When it is desirable that the first eost shall be as snall as possible, and if the expense for fuel, rather than the crops grown in the honse, is considered, the lean-to 
form, particularly if the structure is to be a small one, will be found of value. An idea of the shape of the house, and the reason for the name, can be obtained from Fig. \%. If the house ean be built against the south wall of a building, or against a steep sidehill, these will be additional reasons, as affecting the cost of crection and heating, for using this form of construction. On the other hand, this shape for a greenhouse has, per-

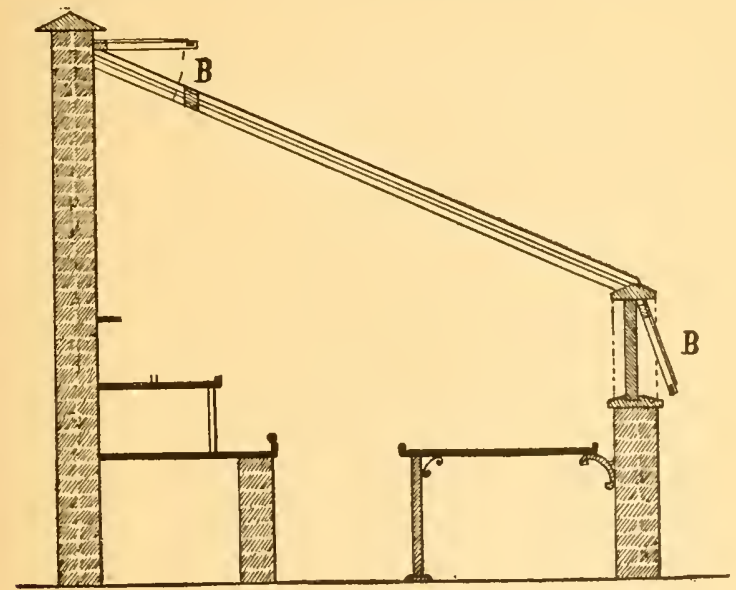

FIG. \%. LEAN-TO HOUSE (Cross Section).

haps, more and greater objections than any other. One serions fault is that for three hours in the forenoon, and an equal period in the afternoon, the plants get little or no direct sumlight; another objection is that the light that they do get, coming all from the south side, is unequally distributed upon the plants, and the leares are all turned in that direction, thus giving the planits an uneven appearance.

As grape or peach honses, the lean-to constmetion answers very well, and, where one has a will that can be 
ntilizer, the expense for builling and heating will be very small. A lean-to, with its roof sloping to the north, answers very well ats a propagating honse. One of the simplest ways of bnilding one is to place it against the north wall of a three-quarter span honse, or by bnilding an even span house twenty-five feet wide, and cutting off six and one-half feet on the north side, thus forming, on one side. what is known as a north side propagating house (See Fig. 61), and on the other a three-quarter span forcing house. As a small house for an amateur, quite sutisfactory results can be obtained from a lean-to, but a span roof house is to be preferred.

For the forciug of vegetables, the growers of lettuce at Arlington, Mass., and vicinity, use wide honses constructed on the lean-to plan (See Fig. S3), and they give excellent satisfaction. As a l'ule, lean-to houses are built with a wall from fom to six feet high, and with a roof of a width in proportion to the widtl of the house; but they are sometimes built quite narrow, with a low wall, just high enough to allow of bottom ventilation, from which the sicle sash rises at an angle of from fortyfire to sixty degrees, to a height of eight or nine feet, with a narrow ventilator connecting the top with the back wall. A good idea of the form of this house can be obtained from Fig. $9 \%$ 'The principal use of a narrow lean-to of this kind, would be as a cold grape or peach house.

In a general way, the construction of a lean-to house woind be the same as of half of a span roof honse, and, so far as the building of these houses is eoncerned, they will be treated under the same headings, and will receive no further consideration as distinct houses.

SIDEHILL HOUSES.

A modified form of lean-to, which combines its advantages with those of the three-quarter span house, 
is sometimes known as the sidehill house. II. C. Strong, of Massachusetts, erected a house of this kind at Brighton, and was well pleased with it. Other smaller houses have since been erected, and, for vegetable forcing, have given excellent satisfaction. A good idea of the construction of the honses can be obtained from Fig. 8. They should be located mon a hillside which has a slope towards the south of about twenty-five degrees. Each section should consist of a lean-to structure of any desired width, from ten to twenty-five feet. 'The soutl wall is built the same as for any greenlonse, and, for a structure fifteen feet wide, posts should be placed

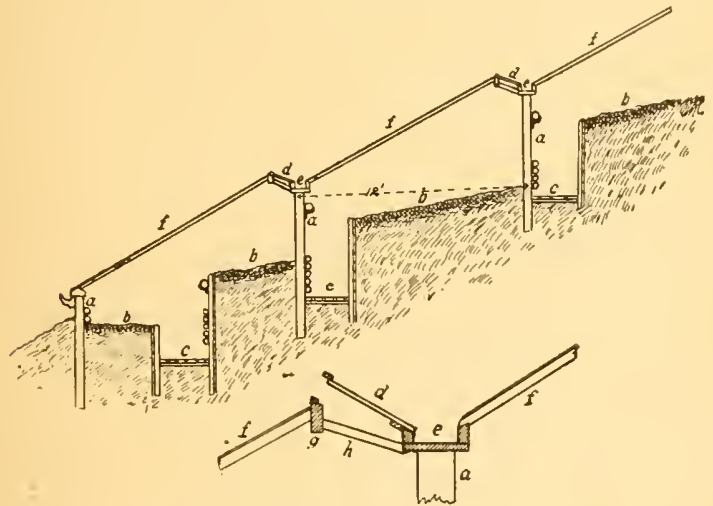

FIG. S. SIDEHILL HOUSES (Section).

in the ground, as at $a$, for the north wall; a gutter should be placed npon them, and this will answer for the south gutter of the adjoining house. 'The sash bars should be laid at the same angle as the slope of the hill, against a ridge, $g$, which should be about two by four inches, as should the sides of the gutters, $e$.

The ridge is supported by liraces about two by four inches, which are placed at intervals of two and one-half 
feet, as is shown at $h$. 'The rentilators, the construction of which is shown at $d$, are of wool, and will be found convenient to walk upon in removing the snow and making repairs, otherwise they could be of glass, if preferred. The benches may be arranged as is most convenient, the method shown in Fig. 8 being an excellent one. The heating pipes may be arranged along the sides of the walks, but should be so distributed that the lower houses will have their share of the heat.

In Europe, houses of this form are very commonly nsed, and regetables of all kinds are grown ont of season, in much the same way as in the open air. Hnudreds and thomsands of acres are thus covered with glass, and the profits of a quarter of an acre are sometimes more thin from the best hundred acres used in general farming.

\section{CIIAP'TER III.}

THREE-QUARTER SPAN HOUSES.

As previously stated, the first form of three-quarter span honse was the same as three-quarters of an eren span structure, but the shape of the roof has been somewhat modified, so that the plants will be nearer the glass. The cost of building these houses is about the same as for an eren span, but owing to the fact that the north wall is from six to eight feet high, there will be less loss of heat from the north side of the roof, and the south pitch of the roof will take in more of the Jight and heat rays, than would be the case with a span roof house.

The three-quarter span houses may be likened to a lean-to house with the peak of the roof cut off. In the lean-to the heat tends to rise into the angle of the roof, 
and hence is not erenly distributed, but in the threequarter and eren span honses there is less tronble from this. 'The three-quater span homses always run east and west, and the north slope of the roof allows the light to fall on the plants from all sides, so that the growth of the plants will be stronger and more symmetrical. It is the south slope that is principally relied upon to trips the light and heat of the sun, and the angle at which the glass is arranged is that which will be nearest at right angles to the sun's rays during the winter months.

This form of house is particularly adapted to the forcing of roses, and of all other plants that need a maximum amount of light for their development. In Fig. 9

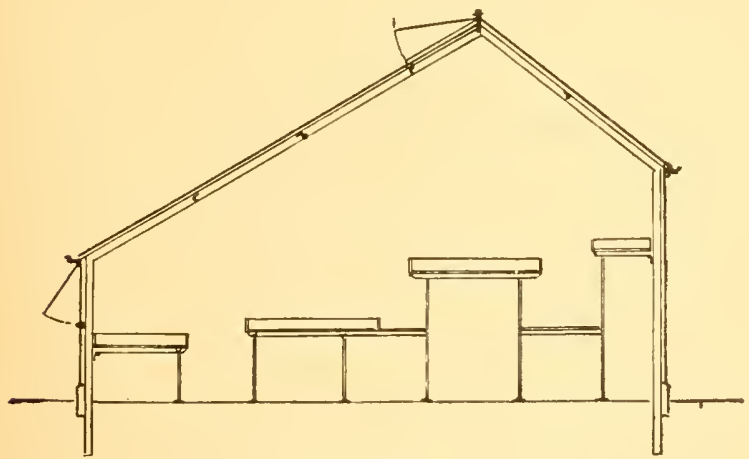

Fig. 9. THREe-quarter SPAN HOUSE (Section).

will be seen the usual form of forcing louse of the threequarter span style. For adapting it to different erops, the height of the walls, the slope and length of the sash bars, and the width and height of the benches, can he raried at pleasure. As a general rule, the three-quarter span houses are from sixteen to twenty feet wide; the south wall is from fonr to fire feet high, and the north one from six to eight feet. The south piteh of the roof 
varies from twenty-six to thirty-five degrees, and the north one from thirty-fire to sixty-fire degrees.

The side benches are each about three feet wide, and are placel about one and one-half feet below the plates. The center bench may be single (Fig. 63), with a slope to the sonth, or double, as shown in Fig. 9, with a narrow walk between the two parts. 'This style of house is also largely nsed for lettuce foreing, and for this purpose the width is sometimes increased to thirtyfive feet.

CURVILINEAR ROOFS.

In this construction the sash bars are more or less curved, with the idea that, at all times of the day, some of the glass will be at right angles to the sun's rays. This, of conrse, is secured, but the result of the eurred sash bars is to decrease the angle at which the rays strike a majority of the panes, so that, after all, the curvilinear construction is an injury, rather than a benefit. The old style of curved roof had the sash bars leaving the plate in nearly a rertical direction. and with most of the curve in the lower thirr of the roof. As a result, the upper half of the roof approached the horizontal, and male a very small angle with the sun's rays, espeeially during the winter. 'The present form of curvilinear roof has a more regular curve, and, as shown in Fig. 10, is less nljectionable. Whaterer the material used, the cost of the framework for a curvilinear house is considerably more than for a straight roofed honse. If, for glazing the roof, glass bent to the proper angle is used, the cost will be much more than for straight glass. Ordinary sheet glass can, of comrse, be used npon curvilinear roofs. bnt. especially mpon the old form of roof, comparatively short panes must be used.

'To many persons the curve is a "line of beanty," and a curvilinear house lins a more ornate and finished 


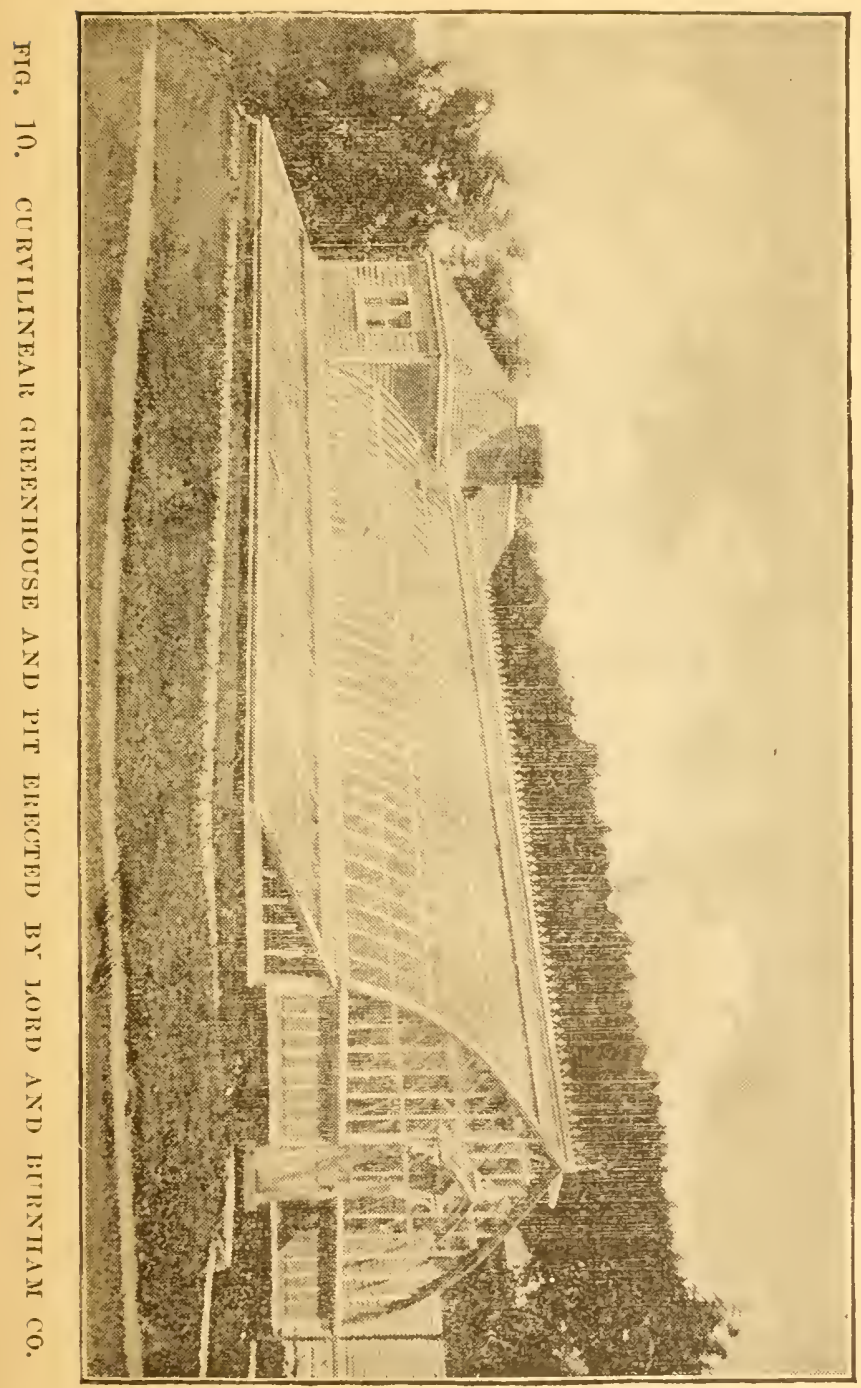


appearance than one with straight sash hars and, in private and public parks, where the increased cost is not considered an objection, and where the houses would be an ornamental feature of the landseape, curvilinear houses have their place. This form of roof is also quite desirable for large conservatories, although a roof made with straight sash bars ean be so broken up as to relieve it of any barn-like appearance. The curvilinear construction can be used in lean-to, eren span, or threequarter span houses, but for the reasons given is not particularly desirable in any form of low, narrow houses, and, in fact, it is generally admitted that better plants can be grown in houses with straight sash bars.

Some twenty years ago the curved construction was in very common use in England, but the general verdict seems to be expressed by a writer, * who says, "Taken as a whole, circular work may, in a few exceptional instances, be introduced to obtain an architectural result, or in molding the lines of a large winter garden or magnificent palm house, but for orlinary growing purposes, we may consider curvilinear roofs not so suitable as those composed of straight lines." As a result of this belief, the curved roofs are no longer in favor, and few such are being erected to-day.

\footnotetext{
* Fawkes, IIorticultural l3nildings, P. 54.
} 


\section{CIIAP'TER IV.}

LOCATION AND ARRANGEMENT.

When erected in connection with some other building, the aspect and slope eimnot always be regulated; but, if possible, greenhouses for most purposes should be on the south side, so that no rays from either east or west will be cut off. For a lean-to or a three-quarter span house the wall or building against which they are erected should lun east and west, and an even span honse should, in this ease, run north and sonth, with its north end against the other structure.

For the location of detached houses, if thorough drainage can be secured, a level spot is not objectionable ; while, if it is at the top of a south and westerly slope, ail the better, as there the sun ean get in extra hours at both ends of the day. In case the land on the most available site is not level, it shonld be graded, in case it can be done withont too great expense. A slope of perhaps one or two inches in fifty feet, to carry off the water from the gutters, is not objectionible, and, while it is preferable that each honse should be practically level, if the land selected camnot be readily graded so as to bring all of the honses upon the same level, there will be no serious objection to having the houses rangerl, one above the other, in regular tiers. For sidehill houses a decided slope is necessiry. In locating the honses, means of thorongh drainage, particularly for the boiler room, should be the first lesideratum. In arranging a group of houses, the wilth and height of the different structures, and the shape of the roofs, will have much 
to do in determining their exact location. Unless arranged in ridge and furrow style, a jace of twelve or fifteen feet between the horses is desiruble. The lean-to and three-qualler splan houses may be placed in parallel lines lumning (art and west, and the even span louses may run in either direction. Besides having them so located as not to shade one another, to prevent side rentilation, or, if desirable, driving between them with a horse and cart, they sliond be as near together as is possible, in order to sirve land, and for conrenience and economy in heating and operating the houses.

The convenience of arrungenent assists, to a wonderful extent, in the performanee of the greenhouse work. The potting and rorkrooms should be centrally loeated, well lighted, and in every way convenient for the work, and in eommercial establishments the packingroom should be so situated as to facilitate getting up the orders. In retail establishments, when the salesroom is in comnection with the greenhonse, it should be conveniently loeated for the customers, and should be fitted np with comnter, glass show cases, lefligerator and of her necessary furniture, Fig. \%6. If properly alranged, with the wire designs upon wall hooks, the baskets and similar supplies in glass cascs, in fact, with a place for everything, and everything in its place, the salesroom will be attractive to customers and risitors. while its convenience, and the arrangements for prescrving the flowers and supplies, will soon rejay all expense. We believe the above efuipment to be almost a necessity in a properly condncted business, and if there is a large retail trade at the greenhonse, some attempt at decoration, both in the silesroom, and in one house to be wsed in whole or in part as a showroom, (ammot firil to attrat visitors, anc? this will increase the trade.

In locating the variuns workrooms for a large establishment, it is well to hare tliem in the center, with the 
houses running out from both sides, east and west. $\perp$ similar arrangement for the heating plant is also ilesirable; thus, rather than have the boiler room at one end of a long range of houses, the boiler house could be placed in the center, and houses of half the lengith arrauged on each side, and better results obtained. A rery convenient arrangement for the heating plant is shown in an engraring of F. R. Pierson's range of rose houses, in Chapter 'Twenty-two, in which four houses, eich one hundred and fifty feet long, are supplied from a boiler honse so located that the extreme ends of the houses are but little more than one hundred and fifty feet away, instead of being orer three hundred feet, as would be the case were the boiler's located at the end of the range. Of conrse, with houses of one hundred to one humdred and fifty feet, such an arringement wonld not be desirable. In many establishments it would be conrenient to widen the connecting passage-way, and use it for potting, packing and like purposes. For a rose foreing house, the potting and packing rooms need not - be as large nor as centrally located as for an ordinary commercial establishment. In large private establish. ments, the palm house is generally the central figure, around which the others are gromped. For a small range the one shown in Fig. 100 is well planned, while that in Fig. 106 has as many merits as a large one. 


\section{CIIAPTER V.}

GREENHOUSE WALLS.

In erecting greenhonses, too little attention is usually pairl to the construction of the walls. Not only should their curability be secured, but the hearing by the frost, and the lateral pressure of the roof, should bo guarded against. Owmg to a lack of foresight regarding some of these points, one seldom sees a greenhouse with five years' service that is in a satisfactory condition. Greenhouse walls are constructed of wood, brick, stone or gront, or of a combination of two of these materials. Each of these methods of construction has its advocates, but each of them has some disadvintages.

\section{MASONRY WALLS.}

The use of stone or grout (ecment, sand and cobblestones), for the construction of the foundation of brick walls, is very common, and, as they make a durable wall, would, no donbt, be langely used for the walls up to the plates, were it not that they are rapid conductors of heat. In small greenhouses, where the grade can be carried up to the plate, so that none of the wall is exposed to the ontside air, they make excellent walls.

The excavation should be to a depth of three fect below the proposed ontside grade level, and of a width to admit of a fifteen or cighteen inch footing course. This should occupy the trench up to the level of the interior of the honse, at any rate, and eren if brick or other material is used for the upper part of the wall, may extend to the level of the ground outside, which is 
often from two to five feet above that of the interior. Stone conducts heat quite rapidly, and for that reason will not be desirable as a wall above ground, unless made very thick. 'This oljection does not hold to the same extent with gront, and where small stones can be readily obtained, it makes a cheap and rery duxable wall. For a house not over twenty-five feet wide, and when less

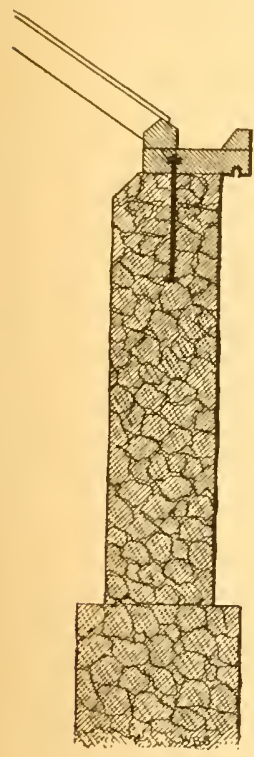

FIG, 11. than five feet in height, a wall of grout twelve inches thick will answer. 'This should rest on an eighteen ineh footing conrse of the same material. The materials required are, stones from two to four inches in diameter, gravel, and water lime, of Louisville or at similar bramd.

In making the wall, a box of the desired width is made by driving stakes along the line of the wall, on each sicle, and setting up twelre inch planks for the sides of the box. In this a layer of stomes is placed, which should be packed ju carefully, and kept, at least, one-half inch away fiom the planks. The eement is then prepared by thoronghly mixing one part with three parts of gravel, and then adding water enough to thoronghly moisten it. The best results GROUT WALL. are obtained, if it is of about the same consistency as ordinary lime mortar. 'T'he water should not be adcled until the eement has been mixed with the gravel. A layer of eement from two to thrce inches thick, over the stones, will be sufticient: this should be well tamped down, filling all of the space between the stones. Another layer of stones and cement call then be added, and the process repeated until the box is filled, 
requiring about three layers. One wall of the house can be built at a time, although if planks are at hand it will be well to allow one wall to set while a comrse is being put in on another. After the grout has been setting for five or six homrs, the planks ean be raised their own width, and the box will thus be prepared for another contse. In this way a wall of any desired height can be

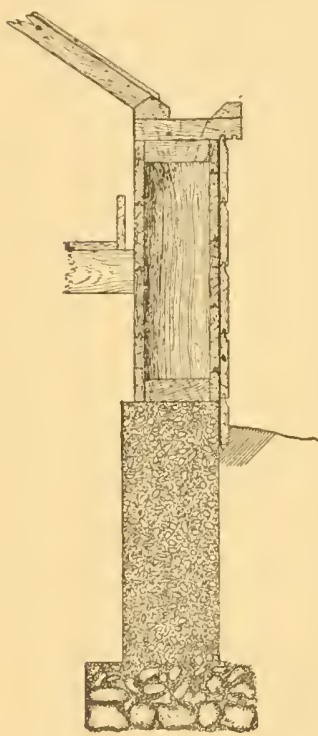
built, which will be found quite durable and in every way satisfactory. 'The appearance of the wall ean be improved if, after the last course lias been put on, the exposed surface is given a thin coat of Portland cement mortar. If desircel, the surface can be laid off into squares, resembling blocks of sandstone. 'The appearance of a wall built entirely of grout is shown in Fig. 11, while Fig. 12 shows a wall half grout and half wood.

\section{BRICK WALLS.}

Unless the very best materials are used in their construction, the greenhouse walls constmeted of brick will be compraratively shortFI. 1\% GROET AND lived, as the combined action of WOOUEN WALL. moisture and frost will disintegrate the mortar, and canse the onter tier of bricks to crmmble. Hard burned brickis shomld be selected, and the best Lomisville, or, better yet, Portland ecment mortar, should be used. Whatever the thickness of the wall, there should be, at least, one air space, to prevent racliation of heat. This will also tend to rencler the wall more durable, by prerenting the capillary passage of the 
moisture. For all low walls, two tiers of brick, with a onc-inch air space, making a nine-inch wall, will answer; these should be firmly tied together every fourth course rertically, and every three or fumr brieks along the walls, Fig. 13. A post once in eight feet will strengthen the wall, and prevent the plates from spreading. For heavy or wide structures, or if the wall is high, a third tier of bricks on the inside, one-half, or, perhaps, two-thirds the height of the will, will serve to strengthen it. Fig. 14 shows the construction of snch a wall, als used with an iron sill.

WOODEN WALLS.

Probably nine-tenths of the present greenhonses are constructed with what might be called post and board walls. In their erection, the posts used should be of sone durible material, such as red cedir, locust or eypress, and the size should vary from four by four inches for low walls and narrow houses, to six by six inches for high walls and wide houses. The posts should be seren to eight feet in length, except on the back sicle of three-quarter spin houses, where a length of ten or

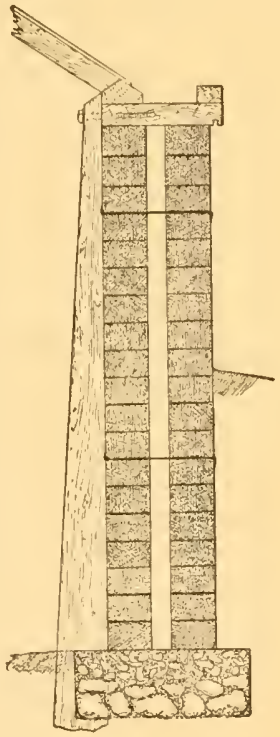

FIf. 13. twelve feet will be necessury, which Brick WALL WITH will allow of their being set three WOODEN SILL. feet in the ground for the front wall, and four fect for the rear one. The posts should be placed in a straight line, about four feet apart, and unless the ground is quite firm and solid, it is well to plice a flat stone under the post, and fill up the hole around " $t$, with gront. This will not only hold the post firmly in place, but it will 
have a tendency to preserve it. The durability of the posts can also be increased by charring the lower end, and then soaking it in crude pretroleum. A coat of coal tar wonld be better than the petroleum, but it should nerer be used about a greenhouse, as it will be injurious to the plants.

The posts should then be sheathed unon the ontside, for which purpose a fair grade of matched lumber is

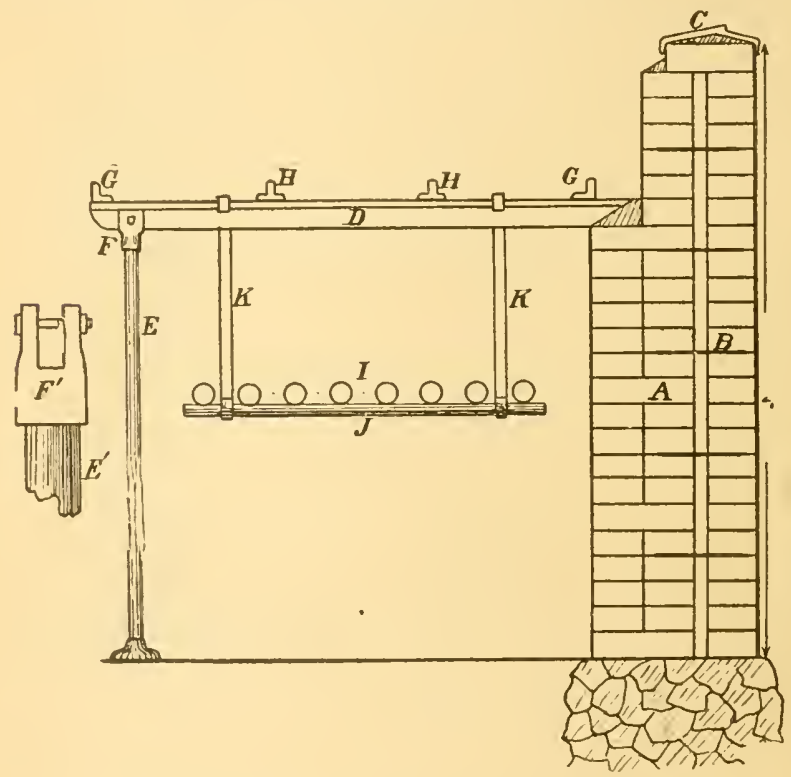

FIG. 14. BRICK WALL WITH IRON SILL.

desirable, although any kind of culled lumber will answer (Fig. 15). It will always pay to corer the sheathing with some kind of heary building paler, aroiding all brands that contain tar. For the onter covering the novelty or patent siding will be found preferable to ordinary clapboards. For rose and stove houses it may pay, 
in exposed localities, to ecil up the posts on the inside: but if this is done it will be best not to pack the enchosed space with sawdust or similar material. This comse was recommended for many years, but, in practice, it was fornd that the packing absorbed moisture and caused a rapid decay of the wall. In ceiling up the inside of the posts, tight joints shomld be made, that will exclude mice; otherwise, the enclosed space may become a harboring place for them, asd thus prove a greater injury than benefit. When used for growing roses and other tall plants, that require the bed to be situated at least two feet below the plate, it is well to have a row of sash in each of the side walls (Fig. 16). If houses run east and west, a row along the south side will answer, although one on the north side will be of adrantage; in north and sonth houses the sash should be placed in both sides. In nalrow houses they may be fastened permanently, but, if the houses are wide, it will

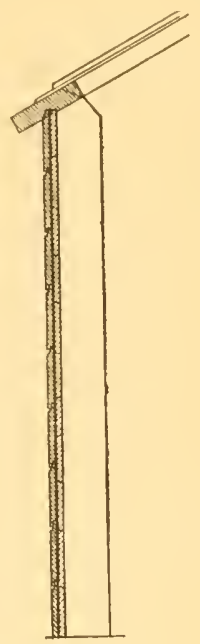

FIG. 15 . be advisable to have, at least, a part of WOODEN WALL. them on hinges, so that they can be opened if fommd necessary (Fig. 50).

\section{PLATES AND GUTTERS.}

'The wall plates may be placed level, on the top of the walls, as in Fig. 12, or they may be at the sitme angle as the roof. As a rule, two-inch lumber is heary enough, althongh if a gutter is desired for catching the roof-water, strips may be nailed to it, as shown in Fig. 12. Another methor of arranging the gutter is shown in Fig. 16. Whicherer method is chosen, the posts. where wooden walls are used, should all be cut off at 
the same angle, and the plate secmely fastened in place. 'The arrangement shown in Fig 16 is the neatest and best, and the sime form of plate, without the gutter, can be nsed when one does not desne the latter. 'The form illustrated in Fig. 1: will be a cheap) and satisfactory method of arranging the gutter, while that shown in Fig. 15 is, perhaps, the cheapest and easlest way of

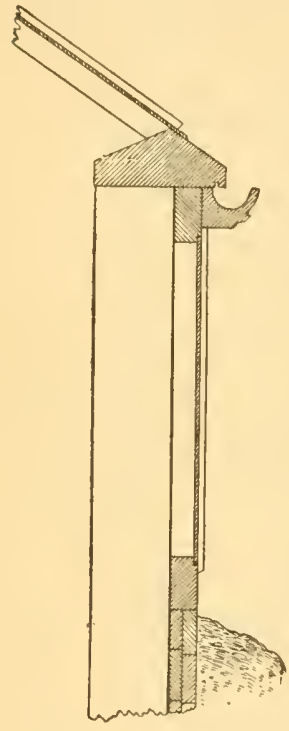
making a plate when a gutter is not desired. When the nuder side of the plate is level there should be a small groove near cach edge, to pre. vent the watcr from working back into, or down the wall.

In some cases a wooden wall built in exactly the same way as the wall of a dwelling house, is preferred to the "post and board" wall. For this a forndation of stone, brick or gront, extending to the outside grade line, is necessary, and an excellent plan is to have two, or even three feet of the wall below this level, with a corresponding excavation for the house, necessitating the rrection of a wooden wall of the same height ahove. In this way the FIG. 16. WOODEN exposed surface is greatly redinced, WALL WITII GLASS and a durable and warm wall will be SIUE. securel. The sill for this wall should be two by four-inch scantling, with studding of the same size, placed two feet apart. The sides and top can be arranged in the same manner as when posts are used (Fig. 1:). If there is danger of lateral pressnre, the sills shomld be seenrely anchored to the fom dation. This form of wall is principally desirable for narrow houses, and where side rentilation is not needed. 


\section{IRON POSTS AND SILLS.}

Although wood is now almost unirersally used in the construetion of commercial houses, many of the more enterprising florists are employing ilon and steel in such portions of the homse as do not form al pirt of the exterior, particularly for posts, sills, purlins and ridge.

One of the simplest and best arrangements of this kind wis used by Lord \& Burnham Co., in the construction of a ringe of rose houses for F. R. Pierson, at Scarborough, N. Y. (For riews and sections of these honses see Figs. $\% 8$ and \%9.) The posts and rafters on each side were made from one picee of four by onc-half inch bar iron, bent at the gutterline, so that when the lower end was rertical, to form the post, the other would be at the proper angle for the rafter. The post end was placed in an excaration three feet deep, resting on a flat stone. FIG. 1\% IRON POST AND and the hole was filled up sILL, WITI SIDE VENTIwith grout. 'The upper eni?

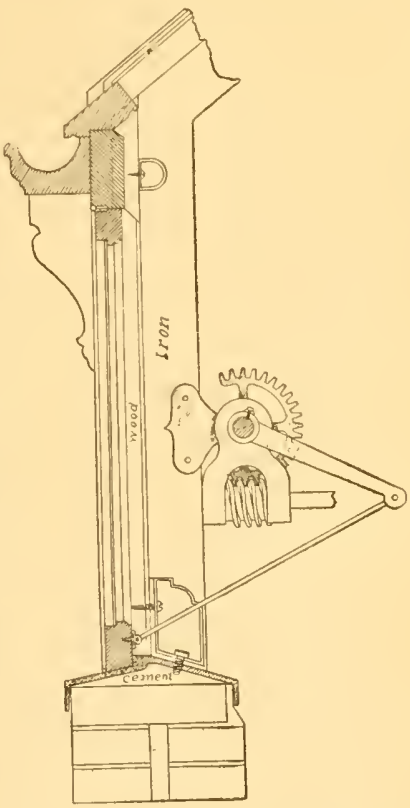
of the rafter was securely bolted to its companion from the other side, by means of an iron bracket. In some cases an iron ridge of the same size of the rafters is useu, to which the rafters are fastened by means of angle brackets.

The wall may be constructed in varions wars, one of which, illustrated in Fig. 9, will answer well for rose 
houses. If desired, the entire wall beneath the plate may be of wood, although the glass will generally be found desirable. It will be noticed that the wooden por tions of the wall are bolted to the posts by means of small iron lugs (Fig. 1\%).

The form of post used by Hitchings \& Co. is rather more elaborate and ornamental than the above. It consists of a cast iron post base below ground, to which the T iron wall post is bolted. The rafter is then bolted to the top of the wall post by means of an ornamental iron hracket. In the more claborate conservatories, with a brick or masonry wall, an iron sill, Fig. 1\%, is nsed (a similar sill of iron can also be used upon the top of a wooden post if desired), to which the lower end of the rafters is fastened by iron lugs.

'This is the best form of eonstruction now in use, and when ready eapital is at hand for the erection of good houses, it will be found most economical in the end. As a second choice, one of the forms of iron posts, with a wall of wood, conld be nsed. Even if the wooden wall does decay, the posts, rafters and purins will still reman, forming a stiff and firm framework, which wonlel still support the superstructure. As a rule, the board at the bottom will decay first, and if this is so put in that it ean be easily taken ont and renewed, the wall can be kept in repar for a long series of year's at a small expense. 


\section{CHAP'TER VI.}

CONSTRUCTION OF THE ROOF.

The portion of the house to which the most attention is paid, are the strips supporting the glass. There are dozens of patent sash bar's, and methods of glazing, and yet the old wooden sash bar is still preferred by the commereial florist, while the sash hars m some of the best modern honses are identical in size and shape with those in nse thirty years agos Although the glazung should be so tight that no water can pass through into the house, there will be more or less condensed moisture on the under side of the glass, and to prevent drip as much as possible, it is well to have them with drip gntters on each side. Some florists, however, prefer not to have them.

Ordinary white pine makes a gond sasn bar, and, if kept well painted, will be found quite durable. The southern cypress, however, is generally preferred. It is straight grained, rather more durable than white pine under the best of care, and much more so if they are neglected. Cypress is also stronger and stiffer than white pine, and the sash bars can be made rather smaller on that account. For use with lapped glass, the best form of sash bar, if drip gutters are wanted, is shown at Fig. 18, while, if the drip gutters are not desired, a good form is shown in Fig. 19. When glass from fourteen to eighteen inches wide is used, the roof sash bars shoukt be from one and one-eighth by two inches to one and one-fourth by two and one-half inches, according to the distance between the purlins. The rabbets for the gliss 
should be about half an inch deep and fire-sixteenths of an inch wide. 'The rertical sash bars for the sides and ends shonld be about one and one-eighth by one and

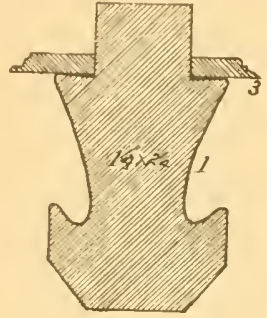

FIG. 18. SASH B.AR WITH INRIP GLTTERS ('́cetion).

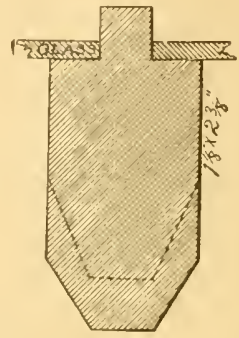

FIF. 19. PLAIN SASII

BAR (Section).

seren-eighths inches, the rabbet being of the same size as for the roof sash bars. For butted glass, whether used with or withont glazing strips, either of the abore forms

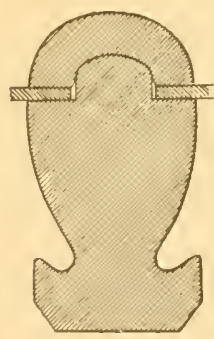

HI(i. : 20 .

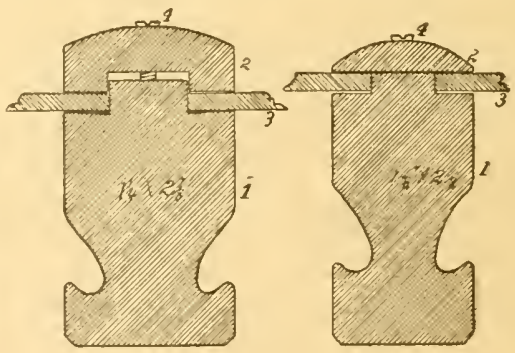

FIG. 21 .

FIG. ¿2.2.

S.ISH BARS FOR BUTTED GLASS.

(Figs. 18 and 19) may be nsed. The patterns shown in Figs. 20, 21 and 22 are, howerer, preferible for this kind of glazing. 'The sish bars (1) there shown are practically alike, and the difference lies principally in the form of 
the eaps (?), those shown in Figs. 20 and 21 being, perhaps, preferalule. In Fig. 23 is show a form of sash bar withont drij) gutters, for nse with butted glass.

As a rule, the lumber working factories do not hare machinery for working (sticking) the drip grooves, and it will be necessary to obtain them from some firm dealing in greenhouse material. There are sereral large concerns who deal in eypress, and finrnish ererything: required in the construction, inclnding gutters, ridge, plates, rafters, sash bars, ventilating sasn, doors, ete. all cut ready to FIG. 23. PLAIN SASH BAR FOR BUTput together.

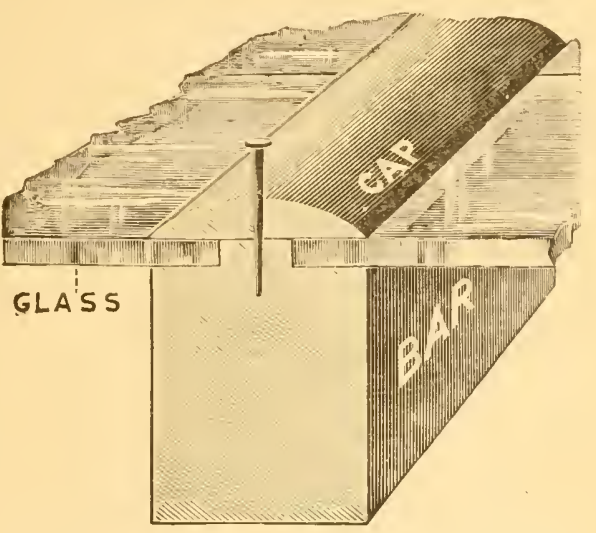
TED GLASS (Section).

This will be a great help to the small florist, as he ean secure his lumber of standard shapes and sizes, with plans that will enable any carpenter to put it together.

\section{PORTABLE ROOF.}

An old plan of construction is to make a framework for the roof, with two by six inch rafters and a heary ridge board (Fig. 24). The roof is eorered with movalble sash, similar to hotbed sash, from three by six to four hy eight feet in size. If the house is narrow, one sash on each side will enver it. The sashes may be serewed to the plate and ridge, and thus make a tight roof. To secure rentilation, some of the sash may he hinged, either at the top, bottom, or siles, or they may be provided with 
stops that will hold one end in place, while the other is raised (see hotbed Fig. 8ij).

In willer houses, in which the rafters measure more than eight feet in length, the space between the top of the sash and the ridge mas be covered with a smaller sash, the lower edge of which laps down upon the large sish bencath. Where two rows of sash are used in this way, it is customary to have all of the mpper row liung on hinges (Fig. 24), atthough if they are rery large, not more than erery third one will be repuired for ventilating purposes, and the others can be screwed down. One

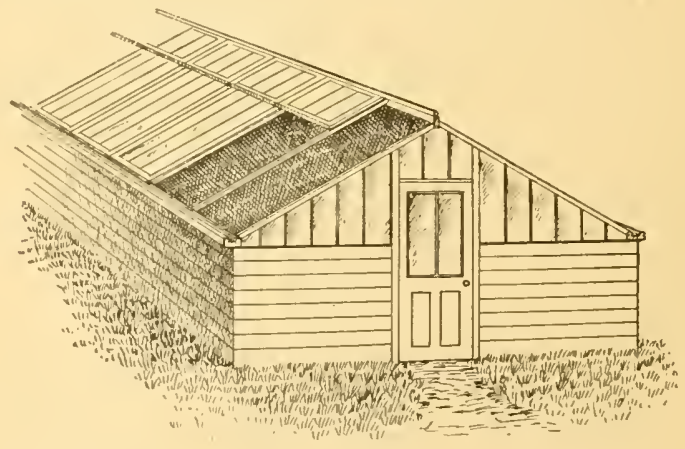

FIG. 24. GREENHOLSE WITH PORTABLE ROOF.

great objection to this kind of a house is that the rafter's obstruet the light and heat, and as the glass used for the glazing of the sash is generally quite small, the sash bars and the sash frame will also be a serious impediment. Where only one row of sash on a side is required, this tromble can, in a measure, be avoided, by dispensing with the rafters and fastening the sash to the ridge.

This form of a roof is desirable when the houses are of a temporary nature, and, to a certain extent, for houses in which crops are forced during a part of the winter ouly, as in growing hybrid perpetual roses. As 
a rule, however, this style of honse is not only more expensive to build, but, for the reasons given, it is less desirable than houses built, with

\section{PERMANENT SASH BARS.}

While many honses are bnilt without rafters, the sash bars being all of one size, the usual foreing house construction is to have every fifth sash bar of the natme of a rafter, either two by four inches, or, in large houses, two by fire inches. The rentilators are then placed in a continuous row on one, or both sides of the ridge, ocenpying a space from fifteen to thirty inches in width, each sash extenrling from one lafter to the next. When this construction is used, a two by four-inch header is mortised into the rafters just under the lower edge of the ventilator, and the sash bars are fitted into this, at their upper end, the lower end being nailed to the wall plate.

Another method of arranging the sash bars with a contimuous line of rentilators, is to have all of the sashbars run from ridge to plate, thus dispensing with the heary light-obstrueting rafters, with short healers between the sash bats, instead of the long ones between the rafters. 'T'hese short heuders should be grooved to reeeive the glass on the lower sicle. The bars in the rentilators should be arranged direetly over the sash bars, but even then, this method of construction is often oljected to, as obstructing too much light at the ridge. This fanlt ean, in a measure, be orereome by entting off every other sash bar, and supporting the header's between those that remain.

A modified form of the rafter construction restricts the rentilators to half the length of the ridge, and admits of sash bars rumning from ridge to plate in the remaining sections. One of the simplest methods of construction is to cover the entire roof with sash bars, 
and then cutting off every eighth sash bar four feet from the ridge, and inserting il grooved header to sup)port it. This will provide for a ventilating sash two to three feet wille, by four feet long, every eight or ten fect, aceording to the size of glass used.

\section{RIDGE.}

The ridge shomld be of either one and one-half or two-inch stuff, and from six to eight inches deep, according to the size of the house and of the sash birrs. It shoukl have a groove for the glass on one side, in case there is but one line of ventilators, or on both sicles if the rentilators are not continnous. The arrangement of the rilge is shown in Fig. 25. The rilge may be surmomnted by a calp, and, partienlarly if the building is a conservatory, an ornamental cresting, with finials at the extremities, shonld be added. Even in case of commercial houses, their attractiveness is so much increased by the addition of some simple forms of suroll finials, as shown in Fig. 5, that the expense shonld not be considered extravagant.

\section{DETIILS FOR ROOF.}

From Fig. 25 the details for the construction of an even span homse eighteen feet wide can be obtained, and, with slight modifieation, they can be used for any other form. In addition to an end view of the honse, the following sections are shown: A side wall with gutter; wall with side plate: ridge and ventilator; purlin; donble gntter for use when two houses are built, with a wall in common ; roof sash bar, and of end wall showing gable raller, end sash bar, and gable sill. The scale for the elevation is threesixteenths of an inch to the foot, and for the details one-sixteenth of an inch to the inch.

In constructing the roof, the sash bars and end rafters should be cut at such an angle as will make a 


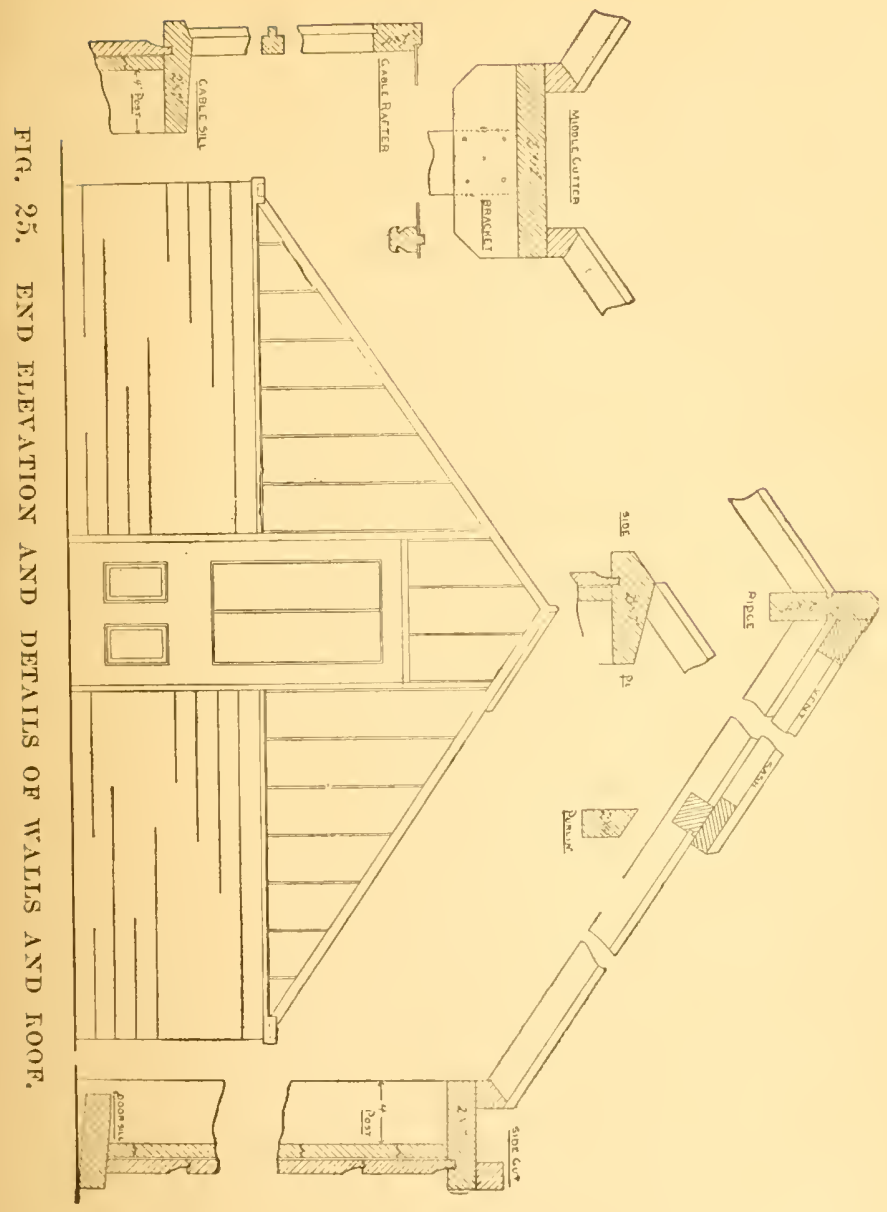


tight joint with the ridge ahove and the plate below, and then firmly nailed in place. If the plates are placed at the sanne angle as the roof, the lower ends of the sash bars should be let in to them about half an inch. As the panes of glass are generally of scant width, if the sash bars are spaced so that they are exactly as many inches apart, measuring from shoulder to shoulder, as the glass is supposed to be wide, a good fit will be obtained.

\section{CIIAP'TER VII.}

COMBINED WOOD ANI IRON CONSTRUCTION.

The unse of iron for posts and rafters has been referred to, and, as the growing opinion among greenhouse men is, that the question of durability should be considered more than it has been in the past, there can be no question but that, in the eonstruction of greenhonses, in the future iron will be quite largely nsed.

\section{IRON RAFTERS AND PURLINS.}

Varions methods of construction are now in nse, one of the best combining a framework of iron with wooden sash bar's. For forcing louses, the rafters are about three by one-half inch, as shown at (1) in Fig. 26, and are surmounted by a wooden rafter cap. The rafters (2) are fastened to each other and to the ridge by iron knees or brackets (3). The purlins are of one and one-half to two-inch angle iron, and are fastened to the rafters by means of iron lngs (4). If desired, gas-pipe purlins can be nsed. With large glass, and small satsh bars, the purlins shonld be quite near together, but as the size of the sash bars increases, or that of the glass decreases, they may 
be farther apart. While forr feet will be none too little, in one case, they may he as much als eight foet in the other. When the ventilators are in long rows, either side of the ridge, the uplex line of purlins should be under the lower elge of the sash, and should carry at wooden header, into which the npper encls of the sish bars are mortised. To the other prrlins the sash bars are fastened by means of wood serews.

When the distance between the rafters or other sup)ports is not over six ol seven fect, onc-inch gas pipes

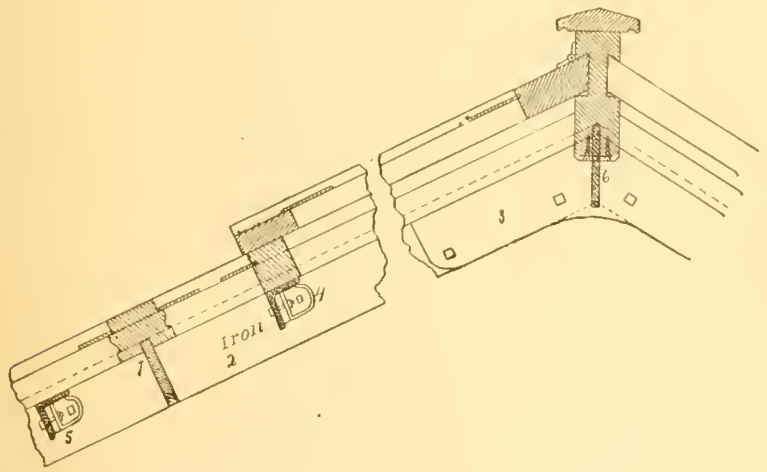

FIG. 26. DETAILS FOR COMBINED IRON AND WOOD ROOF.

will make quite a stiff roof. They can be inserted in holes in wooden rafters when these are used, or can be held "1) by means of small castings attatehed to irou rafters. When the roof is constructed of sash batrs, withont the nse of rafters, a contiunous line of pipe supported by posts, at intervals of six feet, will form a goot purlin. Fig. 2: A shows a gas-pipe purlin, and $l$ ' shows the clips for at taching the pipes to the sash hate. The pipe may be ent in lengths of six fect, and screwerl into the tees to which the posts are attached, or, what is perhaps casier 
to put np, the tees are reamed ont, so as to allow the pipe to slip through them. The lengths are screwed together, and, if desired, can be used as water pipes. If the purlin is connected by screw-joints with one or more of the posts on each side, a hose can be attacher,

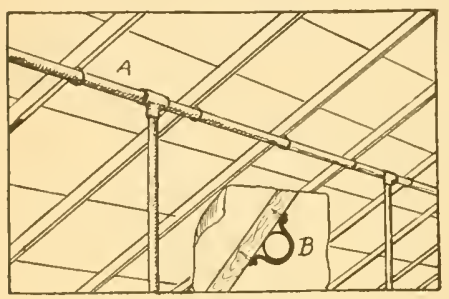

FIG. 2\% GAS PIPE PURLIN. apart, it does not give good satisfaction, as it is more or less likely to sag. In order to hold the sash bars firmly down on the purlins, iron clips can be used, which should be screwed to, at least, every other sash bar.

\section{CENTER POSTS AND BRACES.}

In narrow honses with a walk in the center, no center post need be nsed, as, if the wall posts are firmly set, and particularly if a truss bracket is used in the angle of the roof (Fig. 2S), there will be no danger of its sagging. As the width of the house increases, a necessity arises for either suplorting posts or truss rods.

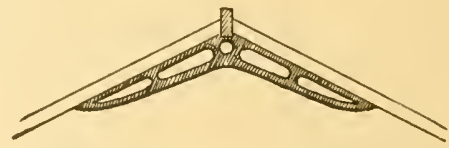

FIG. 2S. IRON BRACKET FOR ROOF.

In wooden houses over fifteen feet wide, where there is no center walk, it is necessary to have a row of gaspipe posts, either one inch, or one and one-fonrth inches in diameter, to support the ridge pole, and if rafters are more than eight feet long, another row should be used to support them in the center. 
In wirle houses the rows of supporting posts shonld be about six feet apart, we for each purlin. When the posts would stand in the walk, if placed rertically, they may be arranged as braces from the ecnter posts, either as shown in Fig. 29 or in Fig. 60. If the ridge is supported there will be no danger of the walls spreading, eren if diagonal braces are used.

In one or two houses of recent construction the posts hare been used as legs for the center bed, by inserting tees, into which the cross bearers for the bed are

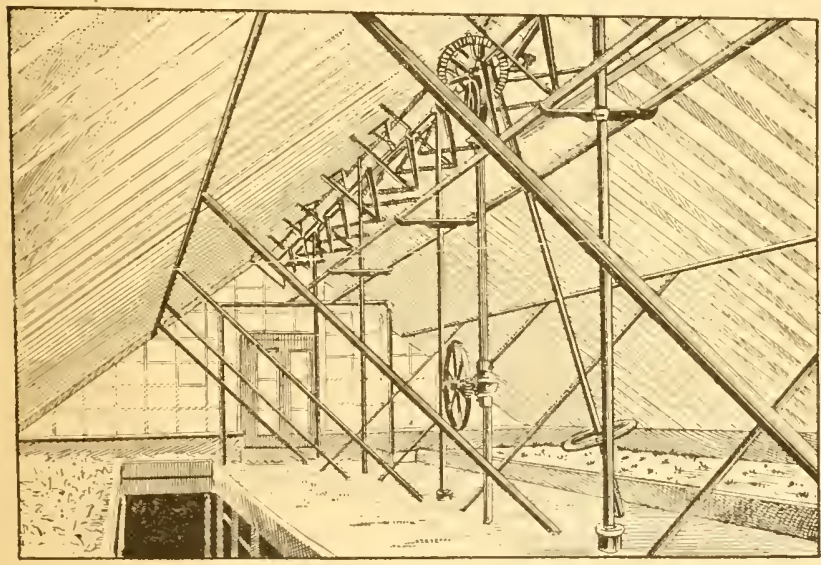

FIG. 29. IRON POSTS AND BRACES.

serewed. The upper ends of these posts are fastened, by means of top castings, to wood or iron rafters, or by means of the tees previously mentioned to the pipe purlins. 'The lower end of the posts may be inserter into ceclar blocks, or rest on masonry piers, either npon flat eastings (Fig. 14), or in beds of cement.

When irou rafters are used, particularly if there is a solid shoulder at the eares, or if the roof is strengthened at that point by a strong angle bracket, there will be no 
necessity for supporting posts unless the house is very wide; but a truss rod, if necessary, may be used to keep the roof from crowding the walls ont.

\section{CHAP'TER VIII.}

\section{ILON HOUSES.}

We have, thus far, only considered houses construeted of wook, or partly of wook and iron, but, for many years houses built entirely of iron and glass have been used in Europe, and they are now frequently seen in this country. In faror of these houses it is climed that they are almost indestructible, and that, if the iron is galvanized, there will be no necessity of painting the honses. In some cases, zine or eopler is nsed for the sash bars, and the same claims are made for those houses. For the most part, these claims are true, and, although one could afford to pay an increased price for iron houses that would need no outlay for repairs or renewal, provided everything else is equally desirable, there are sereral serious objections to iron houses, that have, for the most part, restricted their use to large conservatories, and, even there, the combined wood and iron construction is fairly holding its own.

The objections may be stated as follows: 1st. As iron is a rapid condnetor of heat, the amount thus taken from the louse by the iron sash bars will be, perhaps, three to five times as great as would be the ease were. wooden sash bars of the same size nsed, and this requires a notiecable increase in the amount of fuel consumed. Several builders of iron houses, however, have so reduced the amount of iron exprosed to the onter air, that, so far as ratiation is concerned, there is, perhaps, no great difference. 
21. With several of the methods of glazing, the packing nsed, although tight at first, soon becomes loose, and allows the heated air to escape through the eracks.

3d. Even if the roof is water-tight, there will be a large amount of water congealed on the under side of the sash bars at night, which, melting as the heat rises in the morning, causes quite a shower. Frequently, in systems where large glass is used, a metallic strip is placed between the panes to act as a gutter, to catch the moisture condensed on the glass. If it works all right there should be no drip from the glass, but they frequently become elogged.

4 th. Even if such is not the case in England, it is found, in our extremes of temperature, that unequal expansion and contraction sometimes cracks the large pames, unless everything is very carefully adjusted, so that there is more or less broken glass.

These objections lave most force with the sash bars nsed for skylight gliss, in conservatories, and do not hold true to the same extent when used with smaller panes in forcing houses. In conservatories, however, although the drip is not desirable, it does far less injury than in houses used for forcing and growing plants, and one will need to place the greater durability and cheapness of maintenance of the metal roofs against the acknowledger inerease of fuel required to heat the lionses. Thle use of iron sash bars with metallie glazing, for commercial forcing houses, has not become general, as the matter of drip and of fuel, to say nothing of the increased first cost of the honses, are questions of considerable moment with florists.

\section{METALLIC SASII BARS.}

Of the varions forms of sash bars and methods of metallic glazing, the two that have been longest and 
most extensirely used are the Ilelliwell patent system, controlled by the Plenty IIorticultural and Skylight Works, and those in the hands of the A. E. Rendle Co.

IIELLIWELL PUTTYYESS SYSTEM.

The Helliwell system makes use either of a steel sash bar, as shown in Fig. 30, or of a zinc or copper bar, as in Fig. 31. 'The glass is held in place by long

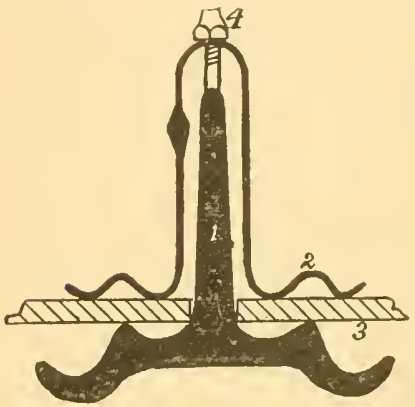

FIG, 30, STEEL IAIR.

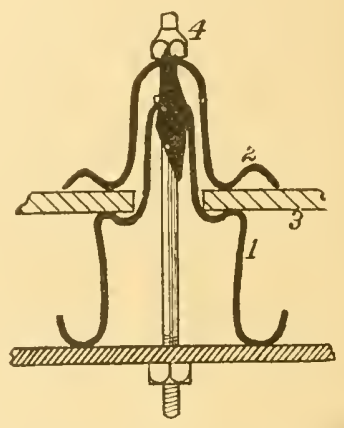

FIf. 31. ZINC BAR. IIELLIWELL PATENT GLAZING.

clips of zine or copper, drawn down upon the gliss by small bolts. It is claimed. by some, that the zine balrs are not stiff enongh. The steel bar does not have this oljection, but it is considerably more expensive. In Fig. 31 the sash bar is shown, resting mpon a purlin, to which it is attached by a bolt. Cande wicking is used instead of putty.

\section{PARADIGM PATENT GLAZING.}

The Paradigm system of glazing, nsed by A. E. Rendle Co., differs principally in the form of the sash bar and in the fact that the gliss is butted. The sash bar is shown at $A$. Fig. 32. It is fastened to the purlins by lugs, as shown in the section. 'T'he grlass rests 
upon the rertical sides of the sash har, and is held in place by a copper eap, $D$, which is drawn down upon the gliss by a small bolt, $C$. The sash bar serves as a gutter, to earry down to the plate any water that may enter between the cap and the glass. When sheet glass is used, all that is necessary is to put it in place and bolt down the eap. When large, rongh plate glass is nsed, cross gutters are inserted between the panes. Directly beneath the points where the panes meet a seetion is cut ont of the sash bars, and a piece of copper, bent as

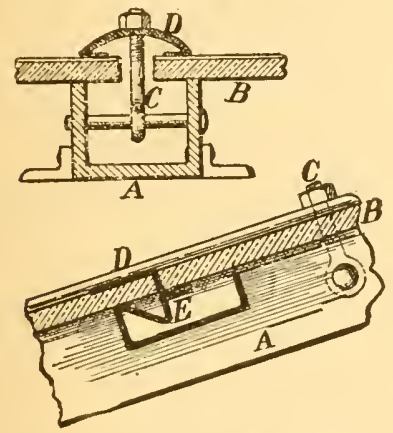
at $E$. is inserted. This not only eatehes any water that enters between the panes, but the condensed moisture on the inside of the pranes is trapped, as it runs down the glass, and is carried to the gutter in the sash bars. If desired, white lead can be nsed in the joints, and an airFIG. 32. PARADIGM GLAZING. tight roof secured. There should be no sag in this sash bar, and it seems to have several features that are valuable.

\section{GALYA YIZED IRON SASH BARS,}

Within the last fow years, galvanized iron has come into use for greenhouse roofs. The framework consists of angle and 'T iron, pit np in abont the same way as when wooden sash bars are used. The rilge cap, cornice, gutters, and all exposed parts of the roof, are of galvanized iron.

One of the simplest forms of iron sash bars is shown in Fig. 33. It is made and nsed in the erection of conservatories, by M. H. Crittenden \& Son, of Mimneapolis, Minn. As will be seen, it nuch resembles, in 
shape. some of the forms of cedar sash hars, and consists of heary galranized irom, bent als shown in the illustration. At the lower enge are broad drip gutters. which will not be likely to lecome clogged. 'The glass may be lad, in any way desired, with putty. A V-shaped cap (:) rests upon the top of the sush bar, and is held firmly down upon the glass (3) loy means of copper clips (4). Unless the purlins are plated quite close together, it would seem hikely that the sash bars would sag, although
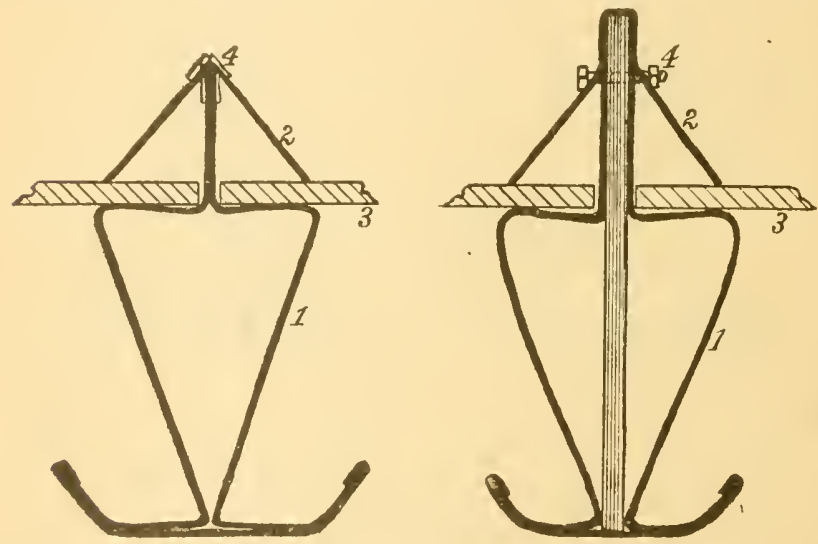

FIA. 33. WITHOLT CORE. FIF, 34, WITI STEEL CORE (TALANIZED IHON SASII BARS.

a nnmber of large lionses are put up in this way, and are saicl to be giving good sativfaction.

A form of sash har that differs from the above, ly haring a core of steel three-sixteenths of an inch thick in the center to add to its strength (Fig. 34), is also usect. The elip holding the glass is drawn down by a bolt. This. of course, is stronger than the other. lont the cost is more. From the form and method of putting 11) these sash bars, there can be but little heat lost, from 
radiation by the iron, and as the gutters seem to he arranged to eatch all of the moistmre condensed, there seems to be fower objections to these sash bars than to almost any of the metallie salsh bars.

\section{CHAPTER IX.}

\section{TIIE PITCII UF TIIE ROOF}

All plants require light, in order to assimilate their food; an optimum temperature is also desirable for the proper performance by the organs of the plants, of their functions. From the sum we obtain not only light and licat, but ehemical or actinic rays, whose effect on plant growth is not well muderstood. In the ease of greenhonse plants, the intensity of the sm's rays is greatly modified by the angle at which they strike the glass, as well as by the thickness and character of the glass itself. It has been found that about twelre per cent. of the light rays are intercepterl, in passing throngh ordinary sheet glass, and sixty per cent. in their transmission throngh opial gliss.

This shows that much can be done by nsing clear glass to present the interception of the rays, and as the additionil amount that is lost by reflection depends npon the angle at which the ralys strike the glass, the careful adjustment of the slope of the roof should not be neglected.

\section{REFLECTION AND REFRACTION BY GLASS.}

When rays of light fall upon slueet glass at a right angle, they pass throngh without being turned from their conrse, and there is no loss, exeept from absorption, which will amomnt to abont twelve jer eent. 
When they meet the glass at an obliqne angle, a portion of the rays are reflected, and the remainder, less those lost by absorption, pass through the ghass, and leave it in the same direction they had before entering.

Fig. 35 illustrates the effect of a pane of glass, $x: y$, upon rays of light falling mpon it at varions angles, $A$ having ninety, $B$ forty-five, and $C$ fifteen degrees. A passes directly throngh and emerges with eighty-eight per cent. of its original intensity. $B$, on meeting the glass, has four and one-half per cent. of its rays reflected to $b^{\prime}$; the balance, on entering the glass, are refracted, or bent from their course, and, on leaving the glass,

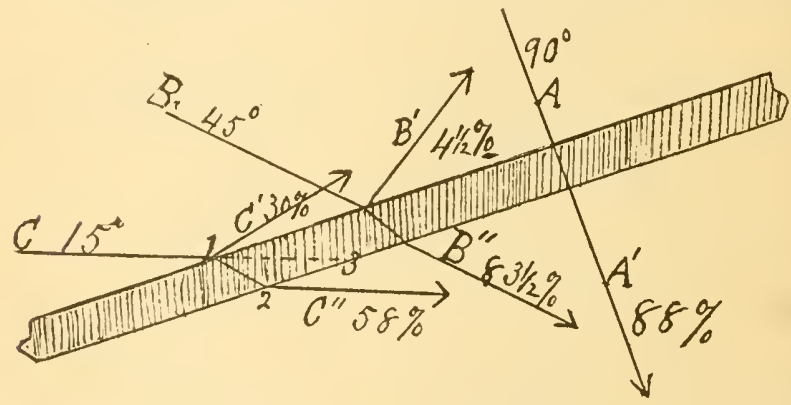

FIG. 35. EFFECT OF GLASS AT IIFFERENT ANGLES.

with eighty-three and one-half per cent. of their first intensity, are refracted, or bent back to their original direction at $B^{\prime \prime}$. The effect upon the rays at $C$, which meet the glass at an angle of fifteen degrees, is not milike that mpon $B$, except that thirty per cent. of the rays are reflected at $C^{\prime}$, while only fifty-eight per cent. emerge at $C^{\prime \prime}$. 'The refraction, if ansthing, especially in the case of very oblique rays, is a benefit. The absorption increases with the thickness of the glass, and it is evilent that there would be more loss were it obliged to take the conrse $1-3$ than there is in its refracted course 1-2. 
The following table gives the amount of light lost by reflection at different angles of incidenee:

Angle of ray 60 clegrees.

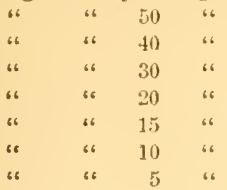

Light lost 2.7 per cent.

\begin{tabular}{|c|c|c|}
\hline 66 & 6" & 3.4 \\
\hline ، & “ & 5.7 \\
\hline "6 & is & 11.2 \\
\hline 66 & " & 22.2 \\
\hline ، & “" & 30.0 \\
\hline 6 & " & 41.2 \\
\hline & ، & 54.3 \\
\hline
\end{tabular}

During the short days of winter, when the sun is only above the horizon for less than ten hours, as many of the rays should be trapped as possible, especially previous to ten oclock in the forenoon, and after two o'elock in the afternoon. At the winter solstice, when the sun is farthest to the sonth, it rises abont twentyfire degrees above the horizon at noon, and the slope of the roof should be such that the amount of ligint reflected while the sun is between the horizon and the above altitude, should be the least possible.

When the pitch of the roof brings the glass at an angle of twenty degrees, the sun, at fire degrees above the horizon, will strike it at an angle of twenty-five degrees, and abont sixteen per cent. of its rays will be reflected, in addition to, at least, twelve per cent, of the remainder, which will be absorbed in passing through the glass. IIad the roof been given a piteh of thirty five degrees, the sun at five degrees above the horizon would strike the roof at an angle of forty degrees, when only five and seren-tenths per cent. of the rays wonld he reflected, or only about one-third as many as were lost by reflection when the roof had a slope of twenty degrees.

\section{THE OPTIMUA PITCH.}

It is evident, from this comparison, that there should be a slope of, at least, thirty to thirty-five degrees, to the roof, and that still hetter results in trapping the rays of light will be obtained if the roof has a 
slope to the south of sixty degrees, or more. The heat and actinie rays, in their passage through the glass, are subject to much the same laws of reflection and absorption as those of light; and in the ease of absorption, the effect produced by semi-npaque glass is eren greater. In determining the proper pitch for the roof of a greenhonse, in addition to considering the requirements for the transmission of the sun's rays in their full intensity, at the season when they are most needed, various practical considerations shonld be taken into account, among which wonld be the height of the side walls, the width of the house, the height of the roof above the plants, and the effect npon the heating of the houses, as well as upon the drip from the glass.

It will at once be seen that it is not a esirable to have a rove so steep as to greatly inerease the glass area, and, consequently, enlarge the consmmption of fuel; while, if it is understond that plants grow best when comparatively near the glass, it will be seen to be mwise, except in "short span to the sonth" houses, to have the roof at a very sharp incline, as it will bring the plants in the eenter of the house at a considerable distance below the glass. With flat roofs not only is the rain likely to beat in between the laps of glass, but the amount of drip, from moisture condensed on the under side of the panes, will be greatly increased. Then a roof has a slope of thirty degrees (seren inches in a foot), or more, there will be no tronble, but at anything nnder twenty-six degrees (six inches in a foot) there will be more or less chip, both from outside and inside moisture.

The use to which the honses are to be put should also be taken into aceount, as if to be used only for wintering over plants, no growth being desired, it will be cronomy, both in construction and heating, to have the roof as level as possible, and as good results will be obtained at a pitch of twenty-six degrees, as in a greater 
one. On the other hand, for crops that resnire an abundance of light for their quick derelopment, the slope should not be less than thirty degrees, and if it can be seenred without interfering in any way with the usefulness of the house in other respeets, thirty-fire degrees would be better.

\section{MEASLRING THE PITCH.}

The following table is given to show the angle that will be made by the sish bars for various wilths of houses, and for different heights of ridge. In using the table, it must be understood that the width is measured from the bottom of the sish bar to a point directly mmlex the ridge, while the height is measured on is plumb line from the upper end of the rafter to the level of the lower end.

ANGLE OF ROOF FOR DIFFERENT HEIGHTS AND WHTHS.

\begin{tabular}{|c|c|c|c|c|c|c|c|c|c|c|}
\hline $\begin{array}{l}\text { Winth } \\
\text { Feet. }\end{array}$ & \multicolumn{10}{|c|}{ Height-Feet } \\
\hline & 4 & 5 & \multicolumn{2}{|c|}{6} & \multicolumn{2}{|c|}{7} & \multicolumn{2}{|c|}{8} & \multicolumn{2}{|c|}{$!$} \\
\hline & 01 & , & 0 & , & & , & & , & & I \\
\hline 6 & $33 \quad 21$ & $3: 448$ & 45 & & 49 & 24 & & 8 & $51 i$ & $1 \%$ \\
\hline 7 & $2 ! 4$ & $35 \quad 32$ & 411 & 36 & 45 & & ts & $4 !$ & $5 z$ & $i_{i}$ \\
\hline 8 & 21633 & 32 & $3 t i$ & 52 & 41 & 11 & 45 & & th & 22 \\
\hline 9 & 2357 & 203 & $3:$ & 5 & 37 & $5:$ & 41 & 38 & 4.) & \\
\hline 10) & 214 & 2633 & 30 & EN & 35 & & $3 s$ & 39 & 41 & 59 \\
\hline 11 & & $24 \quad 26$ & 28 & 36 & 32 & 28 & 36 & 2 & $3 ! 1$ & 17 \\
\hline 12 & & 22 & $24 ;$ & 33 & 30 & 15 & 33 & 41 & $3 i$ & 5 \\
\hline 13 & & 212 & 24 & 47 & $2 x$ & is & 31 & 36 & 34 & $4^{\prime \prime}$ \\
\hline 14 & & & 23 & 12 & 26 & 34 & 29 & $4 t$ & 32 & 4 \\
\hline
\end{tabular}

From the table it will be seen that in an even span house twenty feet wide (ten feet from plate to a point plumb with the ridge), a slope of about thinty degrees $\left(30^{\circ} 5 \mathrm{~S}^{\prime}\right)$ can be olutained by raising the ridge six feet abure the level of the plate (the distanees for both height and width being measured from the ends of the sash bars), while, if it is placed at a height of seven feet, a slope of thirty-fire degrees will be obtained. In the same way, taking the figures for the width from the rerlical columm at the left, and the heght for the ridge above the plate from the upper horizontal row, the num- 


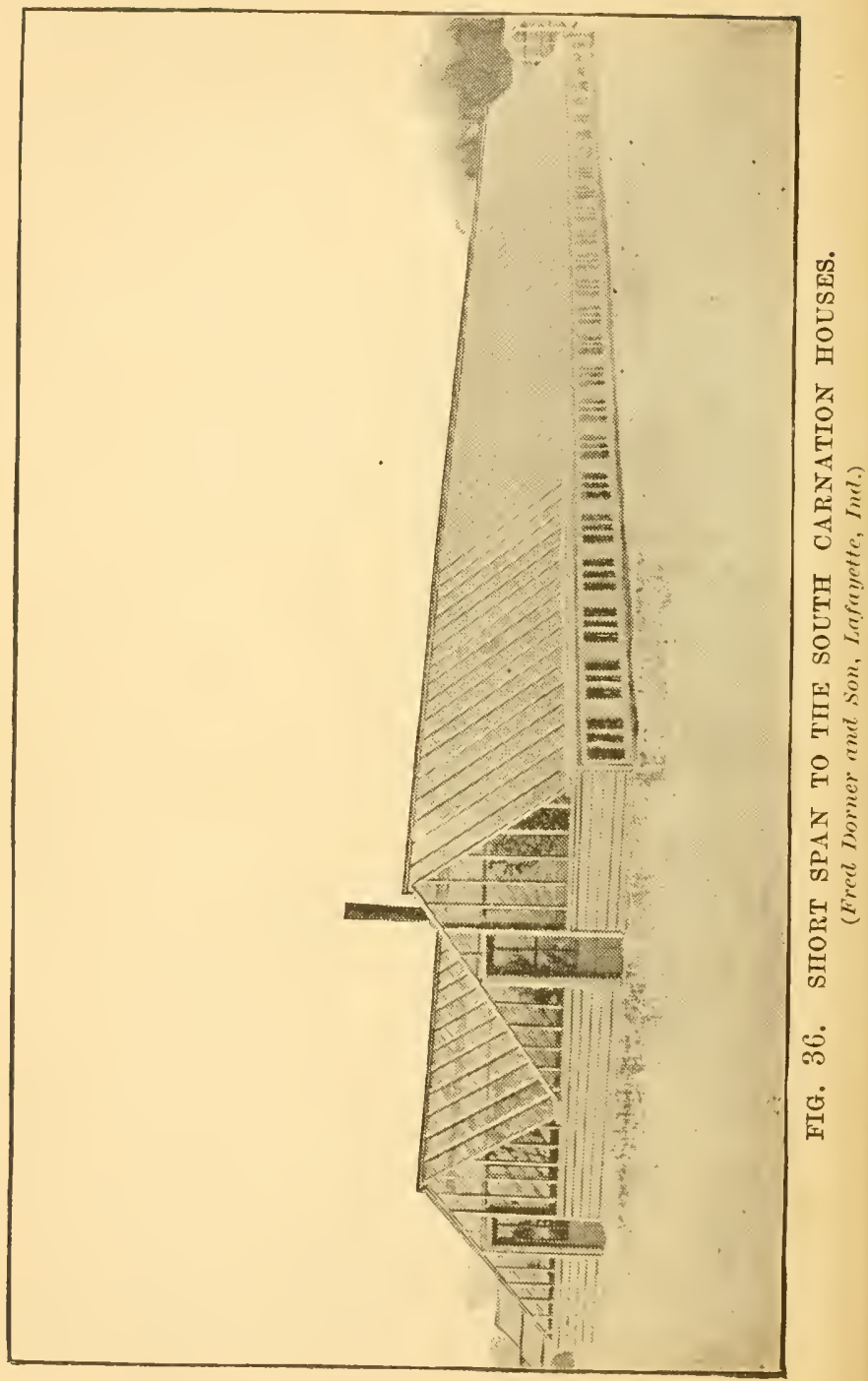


ber of degrees in the slope of the roof will be fouml where the corresponding lines intersect.

\section{SHORT SPAN TO TIIF SOLTII.}

The above remarks apply, for the most part, to the piteh of the roof in even span, or in three-quarter span houses, when the long slope of the roof is mpon the sonth side. It was stated, however, that if a slope to the sonth of sixty degrees could be obtained, more of the light and heat of the sun conld he trapped. During the past two years several houses have been erected with a short spin to the sonth and the long one to the north (Fig. 36), dhffering from three-quirter slatn honses turned half around only in haring both walls of the same height. As will be seen from the engraving (Fig 60), the louses are built with three walks and two wide bets, the north one being slightly lower than the other. It can be seen at a glance that the plants upon the sonth bench are in an extremely favorable locition, and can hatrily fail to do well. The plants upon the north hed, however, are from eight to thirteen feet from the glass through which the sun's rays come, and are more or less shaded by the plants in the south bed. In theory, therefore, as a foreing house this form seems desirable, so far as the south bench is concerned; but for the north bench it does not seem, in any way, preferable to the even span honse, except that the snow does not remain npon the steep south slope, so that there is less ohstruction of light during the winter. In practice, howerer (which shonld be the real test), excellent results are claimed by Mr. George W. Miller, of Hinsdale, Ill., and by others who have tried it. As a summer greenhouse it has long beeu known that this form is a desirable one. 


\section{CHAPTER X.}

\section{GL.LSS AND GLIZING.}

In no portion of a greenhouse have as great changes been mate, perhalys, ats in the glases and the method of setting it. A compraratively few years ago, glass as small ats five by evern, and six by eight inches was nsed; it wats nsually of only single strength, and was of such poor quality that the leaves of the plints were badly burned. The panes were often lappled for an inch or more, and the putty was placel over, rather than under the glass.

'The glats most commonly need to-day is known as sheet glass, either single or doulhle strength. 'The latter' costs somewhat more than the single strength, but it is less likely to burn the plants ausl as it will stand a much harder blow, the breakage from hail storms and by aceidents will be much less, so that it will be ehealper in the end. In selecting greenhouse glass, two points should he borne in mind; (1) it shonid be even in thicisness, flat, and free from imperfections that would cause sun buming; (2) the glass shonld be of good size.

\section{IIFFERENT GRAIUES OF GLASS.}

Glass is gruded as "Firsts," "Áeonds," "Thirds," ete, the grality growing pourer as the numbers cnlarge. 'The imperfections in glass are cansed by air bubbles, mmelted speckis, or varions impurities. As the glass is melterl, the impuritics settle to the bottom, learing the glass at the top yuite dear. From this the "Firsts" or "Ibests" are made; the "Seconds" come from a layer just bencath, and so on to "lifths" and "Sixths," 
which are of quite poor quality. The lower grades are made by less experienced workmen than the ". Firsts," and not only are they more likely to contain imperfections, but they are less 'ren in thickness.

In the past. "Sucomels" of French or Belgian sheet glass have been commonly used, ant are still preferred by most builders, but Americam natural gas glass is now being extensively used, and it cam be said that the "Firsts" are fully as good as French "Seconds," while the American "Seconds" make a rery satisfactory roof. The grade known as "A" quality American glass is suitable for almost any purpose, while "B" quality will answer for miny classes of houres. The natmril gits glass is thought, by some, to be fully equal to the same grades of Enropein glass.

\section{THE SIZE OF GLASS TO TSE.}

The size of glass has been on the increase, until to-day we find panes twenty, and even twenty-fonr, inches wide in use. While this extremely latrge glass makes a rery light house, well suited for growing ruses and lettuce, it is generally thought that a smaller size is preferable. For widths abore eighteen inches the price rapidly increases, and this extra cost will be an injortant question, both at the time of erection, and in case of breakage. When the glass is to be butted, square panes are preferable, as it is likely to hare straight edges at least one way. In sections of the country where the snowfall is heary, the danger of loss from breakige increases as the panes are enlarged, and althongh twenty inch glass may be nsed in the south, eighteen inches will be a maximmm width in the northem states, eren for foreing louses, while, for orlinary florists' houses, the sixteen, and eron fourteen, inch glass is regarded ats the best to nse, everything being considerect.

Unless there is a deciacd cliange, the above width: in lengths of from twenty to twenty-four inches, alle the 
ones most likely to be used. This applies, of course, only to sheet glass, as rough plate or skylight glass and fluted glass may be nsed of a much larger size.

FLUTED AXD ROUGH PLATE GLASS.

The fluted glass has, perhaps, a dozen ribs to the incli, and is used, to some extent, for large conservatories. For houses of this kind, built with metal sash bars, it is, perhaps, preferible to either sheet glass or rough plate. 'The lough plate or skylight glass, as used in greenhouses, raries from one-eighth to one-half an inch in thickness, and from twenty-four by thirty-two to perhaps thirty-two by forty-eight inches. While well alapted for palm, and even for stove houses, it is not desirable for growing houses of any kind, as these, during the winter, need all the light they can wring from the sin.

The amount of light and heat absorbed by glass varies with its thickness, as well as its clearness, and as the fluted and skylight glass are both semi-oparne and (puite thick, they will probably alsorb fully half of the light and heat that enters them, to sily nothing of what is reflected, and their thickness, althongh of advantage in giving them strength, is an objection in growing and forcing houses.

\section{DOUBLE AND SINGLE STRENGTH.}

On account of the increased obstruction to the heat and light lays by the donble strength sheet glass, as compared with thin panes, many prefer the latter for rose foreing louses, but it would seem that the amount lost by the neecssity of bringing the sash bars closer together would nore than comnterbalince it.

Thile double itrength glass costs somewhat more than the single, the greatly redneed loss in ease of hail storms, and the fact that the breakage by frost and other 
causes is less with the former than the latter, make it preferable. It is generally believed that, when in good condition, the danger from hailstorms is only from onethird to one-half as great. "The reports of the Florists" Hail Insmrance Association show that, although the amount of double strength glass insured is in excess of the single thick, the amount of glass broken is nevel more than two-fifths as much, and in some years the ratio is one to one hundred in faror of double glass.

\section{CHAPTER XI.}

GLAZING-METHODS AND MATERIALS.

In setting the glass, the end desired is to so arrange it as to have the roof as nearly air and water-tight as possible, and to have the glass held firmly in place. As usually laid, the glass is lipped, with the nuper pane extending about an eighth of an inch orer the one below it. For curvilinear roofs this is practically a necessity, and when the glass is straight and eren, and well laid, it makes a good roof. Nearly all panes are more or less curred, and if two panes in which the curves are not equal are placed together, there is likely to be a crack either at the corner or in the center of the panes. C'arc should therefore be taken to assort the glass and, if the curves are of different angles, it is well to select those of one angle for one row, and the others for another.

\section{PLTTY.}

For glazing on woorlen sash bars, if the glass is to be lapped, astrals should be selected with half iuch luthbets (Fig. 18), which should first receive a line of putt? sufficient to fill the shoulder. The best gracle of putty 
should be nsert. ant this should be mixed with pure white lead, at tile ratte of one jart of lean to fire of putty.

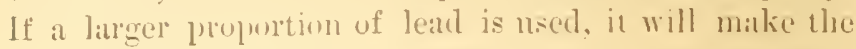
task of claning the batrs a diflenlt one, in cise of lorealiage, while, if the hats are kept properly panted, the mixture, as above, will bobld for many years.

The putty shomle be worlied rather soft, using linseed oil if necessary, and it will be found to stick to the wood best if it is as soft at can $h_{x} 11$ serl without sticking to the hands when they ane well conted with whitinge:

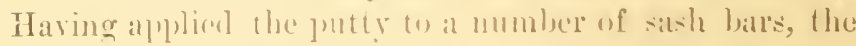
glass is ladid on and carefully puesiced inlo place, squeezing ont all surplu- juty until the mplex end of the jume rests on the hall, ambl the lower upun the pause belun. with al lap not cxceceliug an coighth of an inch. Care should be taken to hatre the curve of the erlatss mp, if

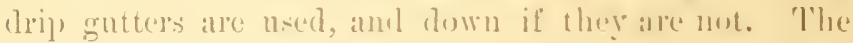
surplus putty, hoth inside and ont, is then scraped off, taling galins to fill ally cracks that may be left. With the old nethed of plateiner the putty on the "lpper sille wf the glass, it was fommel that in whe or two yeals the watter worked muder tlee putty and it scallul ofl, jeavinger a crack at the sirte of the jutm, ats well as molernealls. This

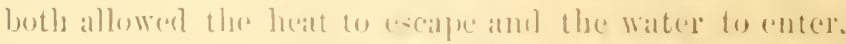
besides premiting the glase to sly down or ble off, if its other fastenings becante lousencul.

\section{(ILAZING POIATS ANI IBR.AIS.}

For holdine the glass in place there are a dozen w.

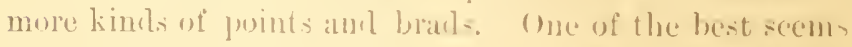

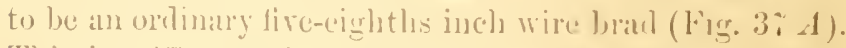
This is stiff cuough to hold the relas firmly in platee,

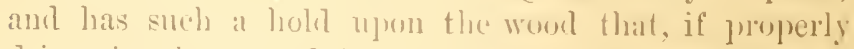
driven in, there need loe no fears of its loosening and

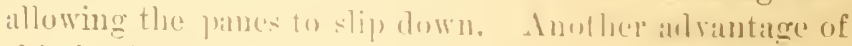
this lond is that it ls inconspicuous, and, conseguently, 
not meightly, and it offers little olstruction to the brusl] when the sish bils are paintert. Ono of the most enmmonly user golazing points is ent from thick sheet zine, and apprears ats in Fig. :3 l). In shape thoy lesomble three-lourths inch sho nails. which are also sometimes ased. When driven well in, this form of hrad has a firm lold, ank, moreorer, is quite stifl: the blunt end, lnomever, tears its waly into the wood, and, muless driven home, is rearlily detaterer. It is also more ennspicuoms than the wire brad, and is a slight himlance to the painting. 'J'wo of these buals are nocel to bold the lower' corners of the glass (lown in place. and two others ale plated about an cighth of an inch from the uppere edge. where they serve to holk the pime in place and to keep the pane above from slipping lown. Lareg pances repuire two other brids in the center.

Of the valioms points nsed for ghazing. nome is better than the zinc triangle. No. 000 (lig. $3 \% \mathrm{r}$ ). While

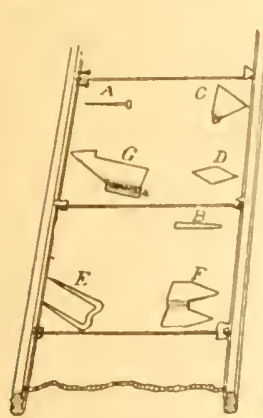

Frf. $3 \%$ the smaller sizes may lo used for the small pances of glass, ol for honse window sish. Where the putty is on the outside. they are not large (mough for lillege erreminouse glass. One of these points is plateed at areh of the lower cornes of the panes, with one angle lappring wrer the edge. After driving it in. this ancle is bent down orer the colge of the lane so that it (ammot slip down. 'Two other prints are used in the midelle of the panes. The diat-

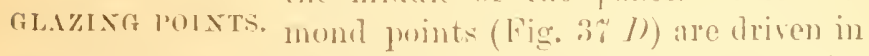
very lapidly with a machine, hut alde rather small for large panes, execpt when the ghiss is butted. Amother point that is sometimes mser is a domble-poinfod carpet tack. This holds the glass firmly in place, but it is not particularly ormamental. 
Tan lieyper"s glazing point (Fig. 3i $E$ ) differs from the above in being bent in the center, so ats to better fit the lower edge of the pane, and to this extent it seems to be an improvement. Eames' glazing point (Fig. 37 $F$ ) is double pointed, and is designed to both hold the panes down in place and to keep them from slipping, and it successfully accomplishes it. Ives' point (Fig. $3 \%(i)$ has a single point, with one corner bent to prevent the slipping of the pane. It is rather thick, and as it tears the wood when driven in, it does not have a very firm hold, even with the shonlder at the point. One objection to the last two kinds of points is that they are "rights and lefts," which leads to more or less confusion in using them, and another which applies to all doublepointed points, is that in order to hold the pane seeurely they must be very accurately driven into place.

\section{BUTTED GLASS.}

The methorl of setting greenhouse glass to which this term is applied, has been frequently adrocated, and has been useil, to some extent, for many years; but it lus never come into general use, principally on aceount of its being somewhat more diffienlt to reset broken glass and make a good joint, than when the glass is lapped. This kind of glazing has miny advantages orer the other, among the more important of which are, that a tighter roof can be malde, thus effecting a saring in fnel; there is less danger of broken glass, either from ice forming between the panes when lapped, or from accirlents, as, when a lappred pane is broken it frequently cracks the one beneath; more benefit can be derived from the smu, as with lapped glass soot and dirt collect between the laps, causing an opaque streak, and eren when this is not so, the donble glass at the lap obstructs more light than the single glass. Moreover, admitting the faet that it is sometimes hard to get a good fit in 
repairing butted glass, using the olel method of glazing, the labor of keeping a butted roof in good condition is less than for calring for one that is lapperl, as there will be fewer breaks to repair, and using the new styles of sash bars the panes can be very realily replacel.

The only oljection to butting the glass in grlazing is, that upon flat roofs, after the glass has heen sot a fow rears, water, in a driring rain storm, will fincl its way between the panes and canse a good deal of drip. On the other hand, upon roof's with an angle of $3.5^{\circ}$ or more, there will be sufficient adhesion between the water and the glass to cause it to run down on the uniler side of the panes to the plate, and thence to the gromnd, or, ats arranged in some houses, either into an insile grutter, or through the wall into the outside gutter.

In laying glass upon the old style of sash bars, a thin layer of putty, or a film of thiek paint, is placed on the sash bar, upon which the panes are latid and tacked in place, taking care to securely fasten the botton pane in each row, to prevent slipping. In order to make the roof both air-and water-tight, it is well to seal the crack with white lead. To do this mix pme white lead with equal parts of good pntty; spread this in a thin larer on a smooth board or pane of glass, and press the lower edge of glass against it before placing on the sash burs.

In setting the panes, crowl them together so ats fo force ont all supplus material, learing the leal to fill ally inequalities between the panes and act as a cement to mite them. When this is properly clone the rows of glass will virtually consist of a single pane, and will remain for several years, both air-and water-tight. In time the lead will work out of the larger eracks, but if they are so large as to prove troublesome they can be refilled with but little tromble. 'l'o make a good job in butting glass, all panes with rough edges should be rejected, or used only at top and buttom. 
IIaving tle panes nailed in place, the clacks at the sides slonlil be filled by applying thick paint with a brush, or, as is preferred by some, by nse of a putty

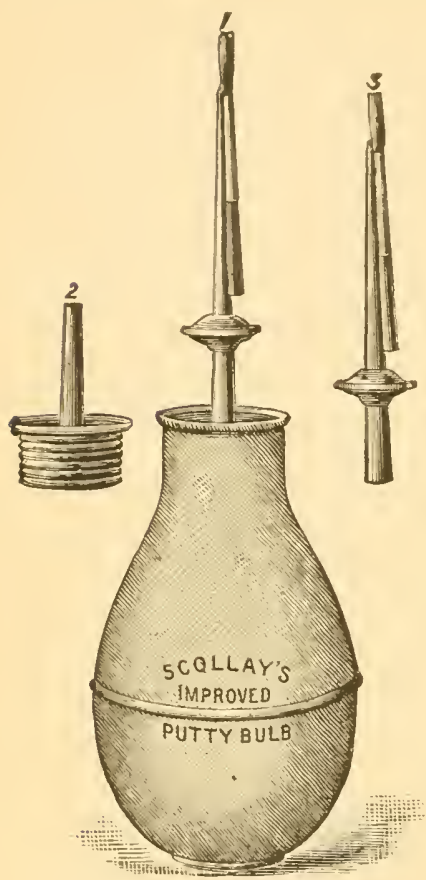

FIG. 38. PAINT BULB. bulb. The name of paint hulb would, perhaps, be as appropriate for the latest forms, which liave a small brush projecting beyoud the end of the tube, by which the crack is filled, and the surplus material hrushed off (Fig. 3S). If rerv much paint is used it will be necessary to sift on sand to keep it from running, but, when properly done, there will be little need of using sand upon it. If desired, the nse of paint or putty under the glass can be dispensed with, although muless the glass fits suugly it will lessen the amount of paint that runs down between the panes. Ires' puttr machine (Fig. 39) is rery convenient for back-puttring in reparing roofs. Upon the more recent forms of sasl bars the glass may be laid in paint or putty if desired. and the crack at the side filled in the same way; or both may be dispensed with, and the glazing performed by melely laving the pames in place on the sash bars (filling the eracks between the panes with white lead, if desired), and fastening the wooden strips in place by means of serews, thus holding them down. 
For use with this methoul of glazing, fiakser"s glat,ing strip is consitered very valuable by many who have tried it. It consists of a marmo strip of zine bent into the form of the letter $z$, as shown in Fig. 40, which is placed between the panes so that one leg of the $Z$ is monder the npper palles, and the other orer the nuter ones. The eracks between the glass and the strip slonuld be filled with white lead, or some other lasting eement, which will fisten them together.

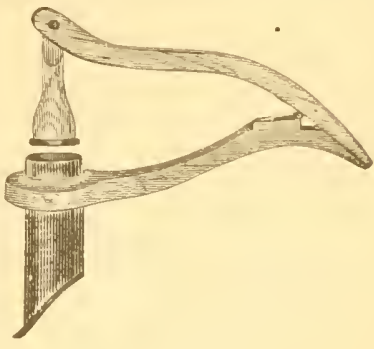

FIG, 39. ITES PITTY

ISACIIINE. and thus make a tight joint. 'This will make a loof water-tight much longer thin when the lead alone is used between the panes. If the strips are not promerly laid, or if they are not comented securely to the cliss,

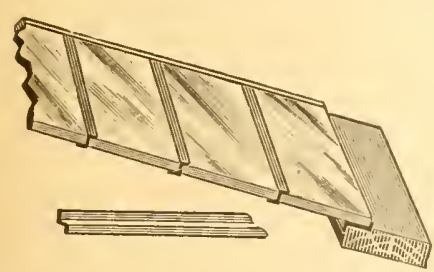

FIG. 40. GASSER'S GLAZING the leakage will be much greater than when no strips are nser. Asite from their cost, and the labor of putting them in, the strijs obstruct al small amonut of light, but with large panes none of these objections are of serious importanee.

From the present light that can he obtained on the subject, the best adrice as to glazing of greenlonses and foreing honses is, nse one of the sash bars shown in Figs. 20, 21 and 22 ; lave the roof with an angle of thirty-five degrees; butt the glass. closing the erack with white lead, or, if a roof that will remain water-tight for many years is desired, use the glazing strip. With glass of a 
width greater than sixteen eighteen inches, it will be best to lap, the panes. When butted glass, laid with the convex sille down, is used. there will be no necessity for drip grooves in the sash bars upon steep roofs, if

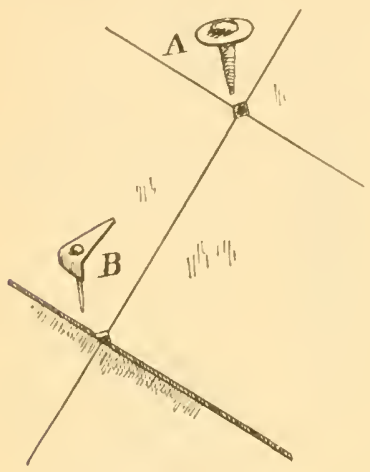

FIG, 41. NEW YETHODS OF GJAZING. there are no eracks at the sides of the panes. One important feuture of this method of glazing is, that when resetting broken glass, instead of bothering to fit the panes, as is necessary with ordinary sash bars, one needs only to loosen the serews that hold the cap, and, slipping up (or down) the remaining panes, place the new one in place at the bottom (or top), and screw down the cap; or, if the panes are cemented in place, one can be selected that will fit the opening.

To be used snccessfully, glass, to be butted, shonld be true and even; as. if panes with different curres are placed together, water will be collected and drip, unless the roof is quite strep. The difficulty increases with large pancs. and sizes over sixteen inches will need to be very carcully selected, if used in this way, even with the glazing strip.

\section{NEW METHOIS OF GLAZING.}

Twn other systems of glazing are shown in Fig. 41, one of which is for hutted glass, and the other for lapped glass. In hoth, the sash bar's are used witlout rabbets, which makes a lighter roof than can be obtained in any other way. In the first method, which was used by J. D. Raynolds, of Riverside, Ill., the glass is butted, as shown at $A$, and is held in place by a screw and washer, 
at the intersection of the panes. By breaking off a small corner from each, the serew can be insertul, and the washer will press the ghass into plare. Py the other method, which was described in the American frlorist, the glass is lapped, and heh in place by a piece of shreet, lead, bent as at $B$. The lower colner of the pances should be nipped off, and an opening makte throngh which a brad or screw ean be inscrted. If desired, a film of white lead ean be plawed between the panes to close up the joints, but no other painting will be necessury upon the exterior.

\section{CHAP'TER XII.}

\section{VENTILATORS.}

For all kinds of plants it is desirable, at some seasons of the year, that means he prorited for supplying fresh air, and for removing surplus lieat. It has been found that, if openings are provited for the egress of the air, fresh air can find its way in, and no necensity will exist for considering that side of the question, exrept during the summer months. As the alir of greenhonses is generally warmer than that ontside, it will naturally tend upward, and ventilation will he most effective if provided at the highest part of the building. 'The ventulators should be arranged so as to prevent direct dirats of cold air upon the plants. They are sometimes placert on both slopes of the roof, in order that the opening may be opposite to the direction of the wind.

In some houses large rentilators have been placed. at intervals, along the roof; lut better results are ob- 
taince when continnons lines of nanow rentilators on one or buth sicles of the ridge are nsed.

\section{CONTINEOLS VENTILATION.}

Then a continuons low of rentilating sashes is used, a small opening will provide the necessary rentilation; but, if they are scattered at interrals along the roof, the openings will need to be two or three times as large, and the draft of cold air npom the plants will be greatly increased. The openings at the ends of the sash invite sicle drafts. It is a poor plan to have a continnous row

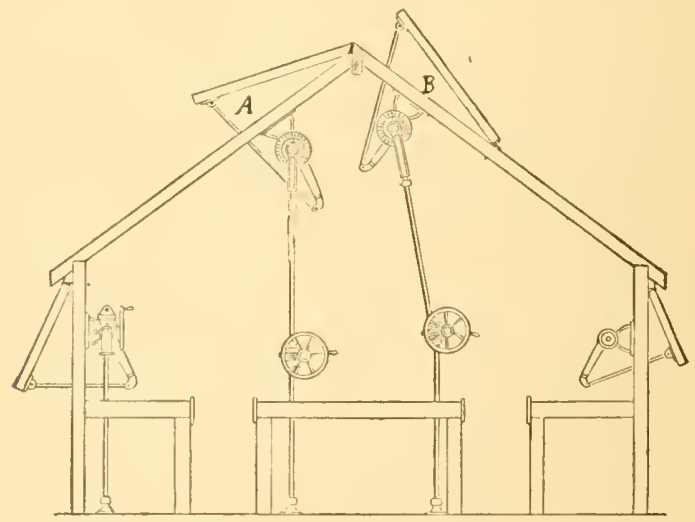

FIG. 4\%. ARRANGEIENT OF VENTILATORS.

of sashes, only part of which are nserl. Particularly if on a high roof, where shafting is necessary to work them, there will be constant tronble from the swelling and sticking of the salsh. Althongh not necessary, the continnous working sals may be fastened together with strijs of band iron.

TENTILATIYF S.ISIT.

The sash should be made in the same war as hotbed sash, with a thin strip for the lower elge. The 
joints should be loeated orer the middle of rafters or satsh bars. 'The glass used for the sasth should be of the same width as for the rest of the homse, except the rous at either end of each sash, which should be somewliat narrower, to allow for the increased width of the side strip of the rentilating sash.

\section{IIANGIXG TIIE SASIT.}

The old method of hanging the salsh was to hare the hinges on the mper side (Fig. 4? A), but as, for the same size of opening, a rentilat or will be nure eflicient when hinged at the lower vilge (Fig. $\left.4: I^{\prime}\right)$, that method will be generilly used, espocially when there is only one line of sash. When only one line is naed, they shonld be on the same side of the roof as the prevailing cold winds come from, when hinged at the bottom, and on the other side if hinged at the top.

\section{VENTILATING MACHINERT.}

In small honses, it simple method of opening the ventilators is by means of what are sometines called skylight fixtures, which are fastened to the lower odge of the rentilator by serew eyes. They have holes at intervals, throngh which a pin on the edge of the header is passed, thus holding the sash at any angle desired. One sash at a time ouly can be opened, and, for houses of any length, some form of apparatus that will open all the ventilators on a given line is lesirable.

\section{A SIMLLE APPARATLS.}

One of the simplest is shown in Fig. 4h. It consists of lifters made of one inch by one-fourth band iron $(B)$, abont two feet in length, fistened riginly to the lower edge of the rentilatur ( $A)$, and extencling down into the honse at right angles to it. 1 small wire cable rmos the length of the house, and near each ventilatur il cord $\left(C^{\prime}\right)$ is attached, which, after lmuning thrumgh a 
pulley, is fastened to the lower end of the lifter. The cable is arranged so that it can be readily drawn through the house, lifting all of the sash to any required height. The motive jower may be applied to a small rope running through pulley blocks, or by means of a small windlass. As first made, they were closed by their own weight, and, as they were not held down in any way, accidents often luaplened in high winds. An improrement (Fig. $43 \mathrm{D}$ ) is in an additional rope, attached to the hottom of each sash, and rumning through a pulley to a point beyond, where it is fastened to the main cable. If the cable at the farther end of the house is carried

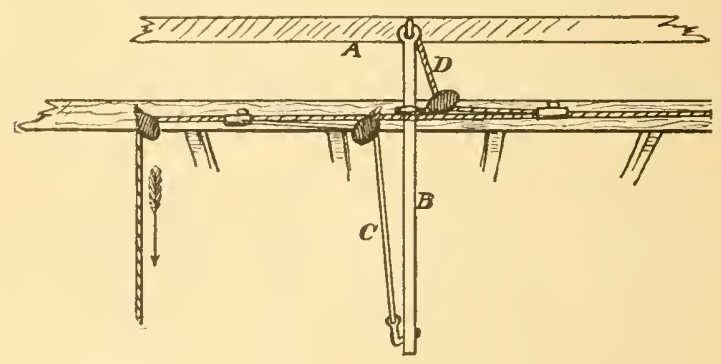

FIG. 43. A SIMPLE VENTILATING APPARATUS.

over a pulley, and has a heary weight attached to it, the cable will be drawn back, when it is desired to close the ventilators, and will hold them securely in place.

\section{SII A FT NG.}

In nearly all other ventilating machinery, the power is conveyer hy means of a gas pipe shaft ruming along nuder the rentilators. In some eases it passes throngh a cross placed in the ridge post, about a foot from its upper end, and in others, it is held in place by means of a clamp fastened to the post. The usual method of fastoning is by means of small hangers serewed to the 
rafters. When sashbars alone are used to form the framework of the roof, some method of hanging the shaft to the posts is desirable, but not necessary.

Varions methods of applying the power have been used, the most common of which is the common elbow

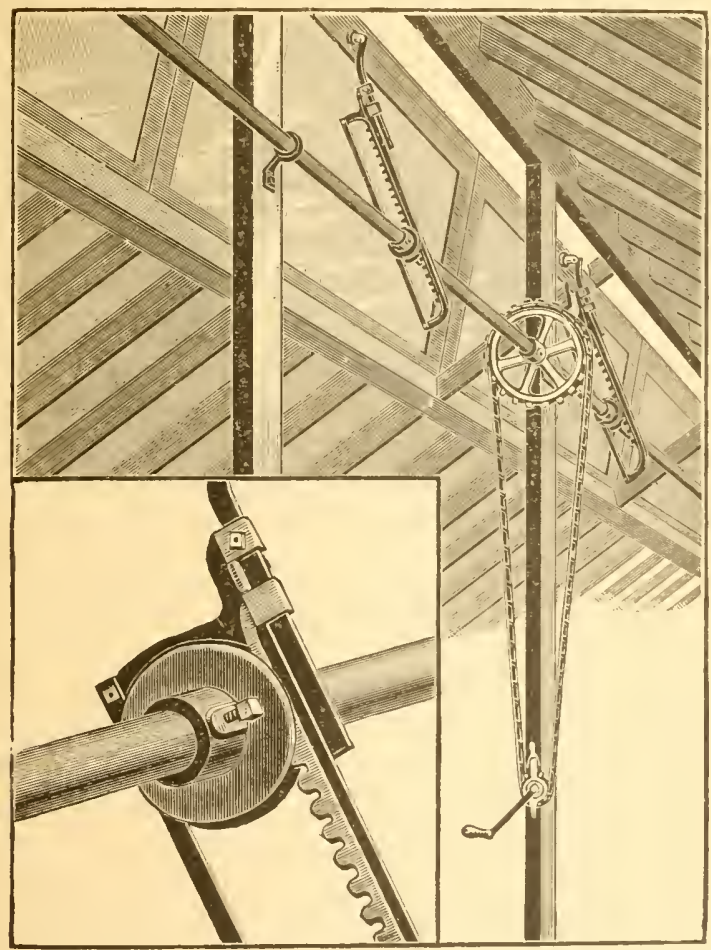

FIG. 41. NEW DEPARTUIE TEXTILATISG APPARATUS.

fixture shown in Figs. 42 and 46 . 'These are strong and do their work well, except that they are applied at a disadvantage when the sash is just heginning to open, and as this is the point at which they are most frequently 
used, it will luare to be regarded as a slight objection. Auother form of fixture is regarded as a "New Departure," by .J. D. Carmody, the inventor. It has much the slape of a meat suw (Fig. 44), and lifts the sash by the action of the cogs on the shafting, upon those on the fixture. It works uasily, and the same foree is

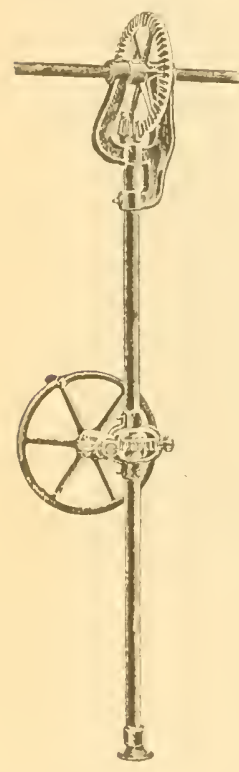

FI\%. 45. required to lift the sish, at whatever leight it may be. A form quite similar to this is used with the Little Victor machine, and is recommended by the inventor, E. P. Hippard, as valuable for small sash.

Tarious contrirances have been arranged, by which the weight of the rentilators, ill elosing, shall coil up a spring, which, when it is desired to open the sash, will furnish a large portion of the power. One of the best of these is known as the Ormsby Spring Jalanee. It has proven quite satisfac. tor'y, and works rery smoothly, opening, with the expenditme of very little power, i long line of sash. It is easy to put np, and the only objection to the system is that, after two or three years of use, the springs wear ont.

Of the machines used to work the STAXDARD. shafting, with its elboir fixtures, the simplest is the kind generally used by greenhouse builder's. It consists of a large wheel mpon the shist, worked by a worm upon the upper end of a rod, to which the power is applied by means of a crank, or a land wheel. It will be found in sereral of the illustrations. Among the more recent candidates for favor are the Standird and ('hallenge machines.

'The former, shown in Fig. 45, is manufactured by E. Hippard, Ioungstown, Ohio. It is a rery easy work- 
ing machine, but does not work quite as fast as some of the others. In the old mathines, the latroe whed on the shaft sometimes slipped, or was pmsherl awa from the surall pinion, but with the new donthle healue there

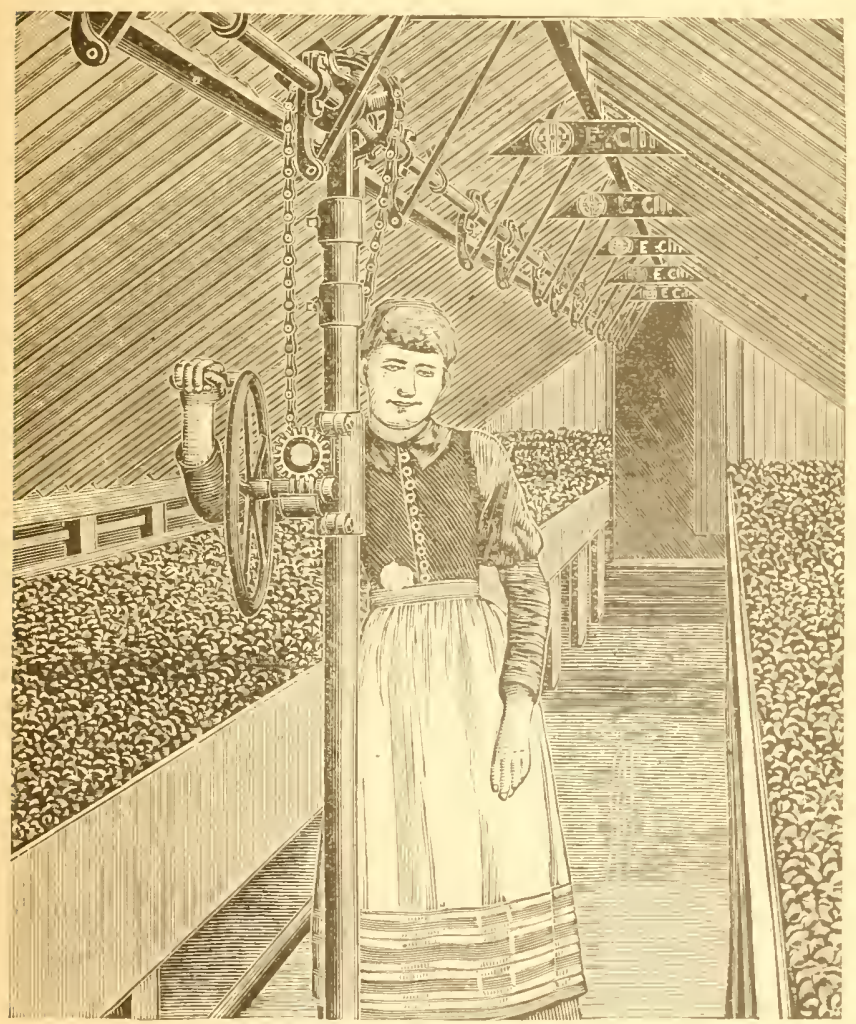

FIG, 46, CIILLENGE.

should be no troub]e. Ls will be seen from the ersgraving; the prower is applied, by means of a hand wheel and worm, to the rertical shaft which works inside the just. $\Lambda t$ 
the upper end of the shaft is a pmon, or hevel gear, by which the power is conveyed to the shaft. We have found it a very satisfactory machine.

'The Challenge machine (Fig. 46) is made by the Quaker City Machine Co., of Richnond, Ind. It differs

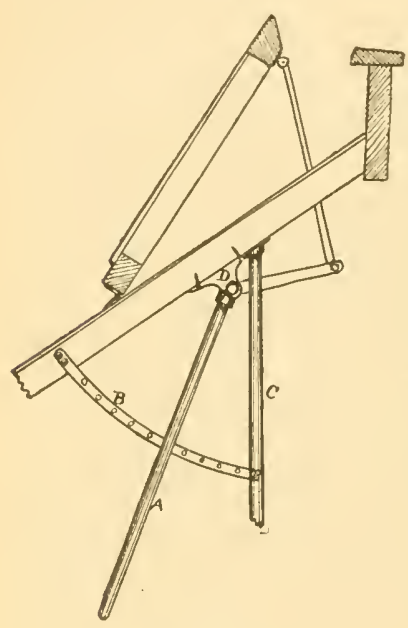

FIG. $4 \%$. from the Standard in using sprocket wheels and an endless chain, instead of a rertical shaft and gearing. The first machines made had sereral slight defects, but these have been corrected in the latest pattern, and the machine now does rery good work. While it does not work as easily as the Standard, it gives a more rapid movement to the sash, and to that extent is preferable to that machine; the latter excels in ease of operation, althongh either ean be

A SIMPLE FIXTURE. changed by varying the size of the gear and sprocket wheels.

\section{CHEAP VENTILATING MACHINE FOR LOW HOUSES.}

In low span roof houses a simple method of working the shaft is shown in Fig. 4\%. It consists of a lever of one inch gas pipe $(A)$, perhaps four feet long, fastened to the shaft $(D)$ by means of a ' $\mathrm{T}$. By means of this, a line of narrow sash fifty feet long ean be opened or closed, and can loe held in place by means of a pin passed throngh a strip of iron $(B)$, as shown in the sketch.

\section{OUTSIIE SHAFTING.}

When the ridge is too low to admit of running the shafting under the roof, it may be placed on the ontside, 
as shown in Fig. 48. In any louse, if, for any reason, the shafting is not desired on the inside of the lomse, this arrangement, which is msed ly Hijpard and otlers, may be emplozed.

While a single ride line of ventilators will answer, in honses less thin twenty feet wile, two natrow lines on opposite sides of the ruof will be preferable. In wide

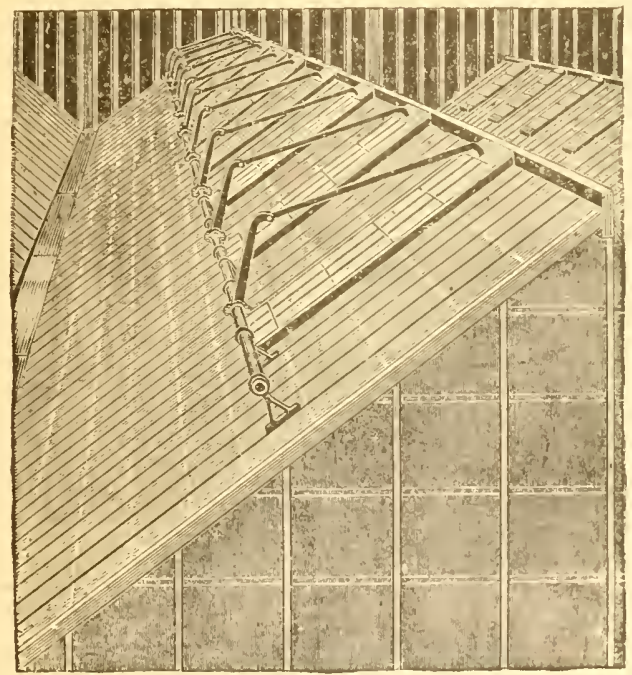

FIG. 48. OL'TSII)E SHAFTIYF.

houses rentiluting sashes in the vertical walls are desilable, and some builders of three-quarter span homses prefer to have one row at the ridge and one in the sonth wall, even in rose houses, to having the two rows at the ridge. In eren span house's there is less oceatsion fol' side rentilation, except in wide houses. In fig. 4 : is shown a variety of methods of arranging the rentilating sash, and of attaching the ventilating machines. 


\section{CHAPTER XIII.}

\section{GREENHOL'SE BENCHES}

The benehes used by the average florist are a constant source of trouble and expense. Built as they usually are, of cheap or waste lumber, their life is a short one, and they frequently break down while in nse, either ruining the plants, or so mixing the varieties as to make them of little value. A wooden bench generally has to be renewed within five years, and in some cases three years sees their period of usefulness at an end. Not only is the florist reyuired to pay for labor and material for constructing a new bench, but, as frequently the weakness is not discorered until the bed is being prepared for use, the deling necessitated ir planting the bed may greatly lessen the profits. The best materials for greenlıonse benches are iron and tile, or slate, but, as the average florist will think he cannot afford this kind of a table, let us consider the next best thing.

\section{WOODEN BENCHES.}

With a little attention in coustructing and caring for wooden benches, their durability can be donbled. When wooden legs are used, they should be raised above the level of the soil and walk, npon a brick or stone pier. 'l'his will not only furnish a firm support, and thus prerent the settling of the bench, but it will serve to keep' the lower portion dry, and check its decay. Red cedar or loenst will make the most desirable legs but, as they cannot always be readily obtained, cypress or pine will be generally used. When the walls of the lionse are of 
wood, the back ends of the cross hearers ean bo matiled to the posts. or to the studling, and in house's consitructol upou a brick or gront wall this cam roulily he userl fol supporting them. Measuring from the inner fares of the wall, the length of the cross bearer shomkl be two inches more than the width of the hench, thus anduitting of at free circulation of air in the reas. When the wall (annot be used to support the backs of the sisle benches, wooden legs cam be used, the same as for the fromts, and for the midalle bench. These shonld be aluont two liy four inches, and from two to five and a lualf feet in height, according to location and the eharacter of the house.

The cross bearers may liange from two by foul inches for narrow benches. to two by six, or eren two by eight inches for wide ones. fastened to the legs, as shown in Fig. $49 A$, there will be little danger of their becoming detached and letting the bench down. If these supports are placed once in three and one-half or four feet, the common six by one inch fence boards ean be placed longitudinally for bottoms, when shallow rose beds are desired, although the twolreinch boards are better for the staging of pot plants. 'To provide for thorough drainage, cracks three-

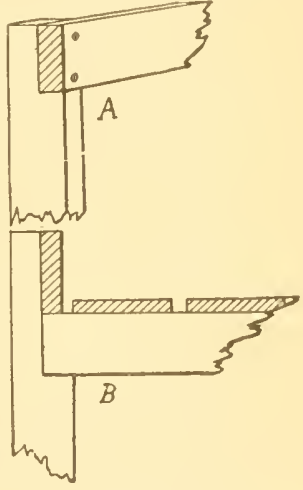
fonths of an inch wile should be WOODEN RENCIES. left between the hoards. If leep beds are to be used, or if large pot plants are to be placed on them, the distance between the supports may profitably be reduced to three feet, or one and one-half inch boards used. For the front and back of the henches strips of boarl from three to six inches wide, in accordance with the kind of 
plants to be grown on them, should be used. If the legs are extended to the top of the front boards, as in Fig. 49 I, they will be held firmly in place and will last mueh longer. 'The logs and cross bearers, as well as the

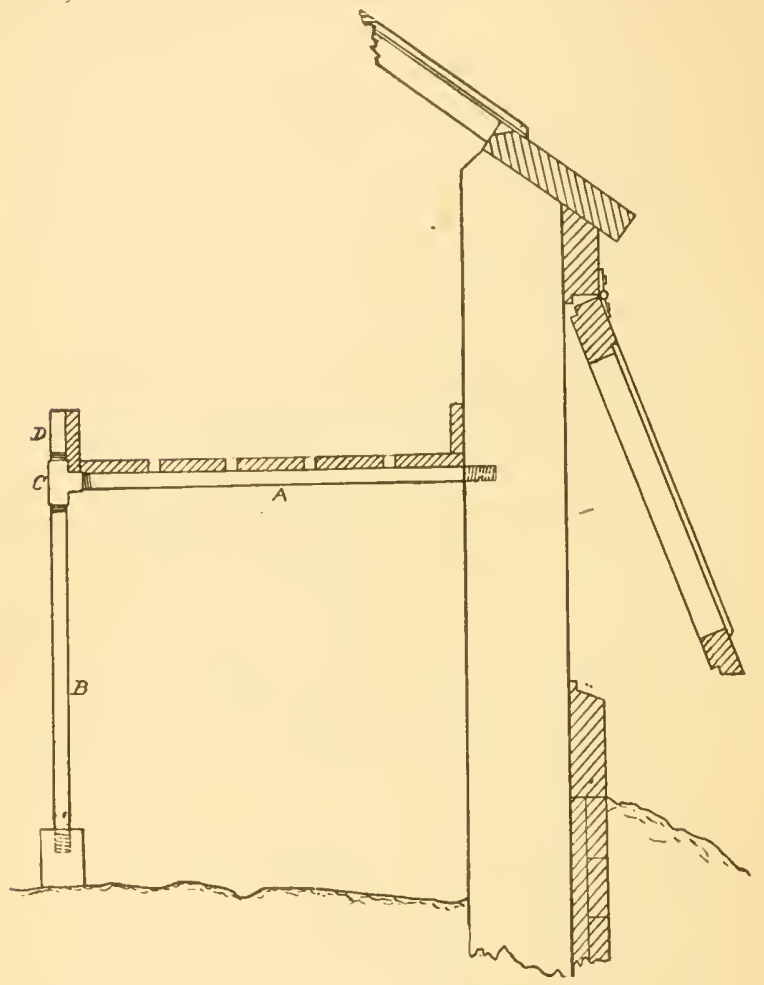

FIF. 50. G.IS PIPE BENCH SEPPORTS.

side pieces, shonld be thoroughly painted before they are fitted together, and this will often double their period of nse. After the bench is completed, it will pay to gire the inside a thorough eoating with Lonisville cement, of the consistency of thick paint. 
The width of greenhonse henches varies, to a large degree, with the width of the hollse, and the uso to which it is put. 'The side benches, in a rose house, are sometimes at narrow as two feet and six, or, perhaps, eight inches, and are seldom wider than three feet and six inches, which should be the maximum. 'T'he center' benches range from fire to-seven fect in width. Whon properly bnilt and well carerl for, benches of this description will be far more economical, in the end, than the cheap constructions generilly seen in greenhouses.

\section{IRON BENCIIES.}

Many florists who are not ready to try the irom and slate bench, are using iron legs and cross bearers. The simplest forms are made of one-inch gas pipe (Fig. 50), the lower end of the leg resting in a cedar block sunk in the gromnd, and the 1 pper end supporting the front end of the

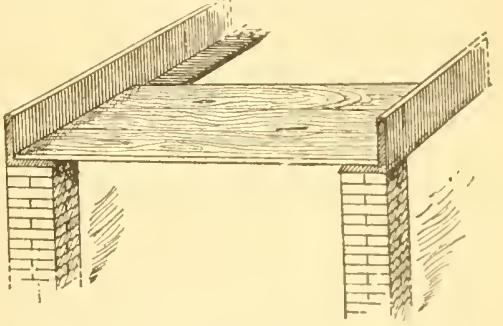
cross bearer, by FIG. 51. MEXDExHAL's BENCII. means of a malleable iron ' $\mathrm{T}$, from the top of which a short piece of pipe extends eren with the top of the front boards, thus holding it in place. 'The front boards can, if desired, be placed outside the pipe, and held in place by iron elips. The rear end of the cross beurer is screwed into the wall post, or set in the masonry, when possible, and if neithel of these methods of smpport cim be used, gas pipe legs can he provicled, the same as for the front. For center benches a somewhat huvier construction would be necessiry, the eloss bearers being uf one and one-fourth inch gis pipe. When houses are 
bnilt on the "ristge and furrow" plan, the cross bearers for the virle benches maly jass thongh the wall into the adjoining honse.

\section{AYGLE IROX BENCHES.}

One of the simplest forms of iron benches was recently figmed in the American Florist (Tol. VI, Page 983), as Mendenhall's bench (Fig. 51). It rested upon brick piers, and consisted of two or three inch angle irons, placed so as to form the front and the lack of the hench. 'The bottom was of slate or hoards, as desirect. By using intermediate strips of ' $\mathrm{T}$ iron, narrow strips of slate, or bench tile could be nsed.

Another form of greenhonse bench has been tried in the honses of E. C. Itill, Richmond, Int. The cross bearers and longitndinal strips are of a light street car $T$ rivils, with bottoms of slate and sides of narrow boards,

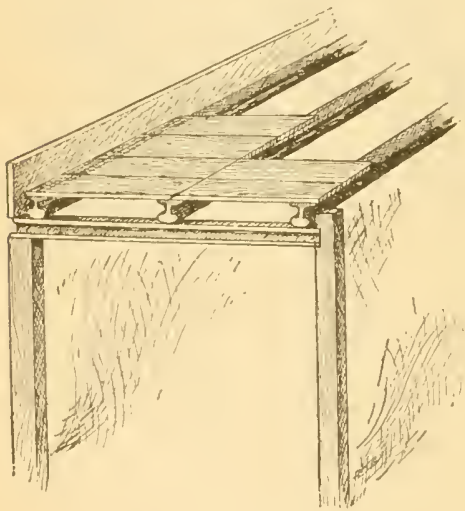

FIC. "). TILL'S TENCI. held in place by narow strips of irom. The bench is supported on cedar posts (Fig. 52). The cost of the jron rails is given as eleven and one-half cents per foot. 'This is consicterably more than the cost of the lighter grades of angle iron, but as the rails are mmch stronger, the number of legs and cross bearers is reduced, which might bring it down to the sime cost. 'The least durable portions of this bench are the sides and legs; the latter, however, conld be made of iron, if desired.

Perhaps the neatest form of iron bench is shown in Figs. 14 and 53. The size of the jron reruired is accord- 
ing to the width of the bench, and the nse to which it is to be put. Fur a rose house, the sirle henches ean be supported on one and one-half incle eross hearors of 'T' iron ( $D$, Fig. 14), placed once in fonr feet, with one and

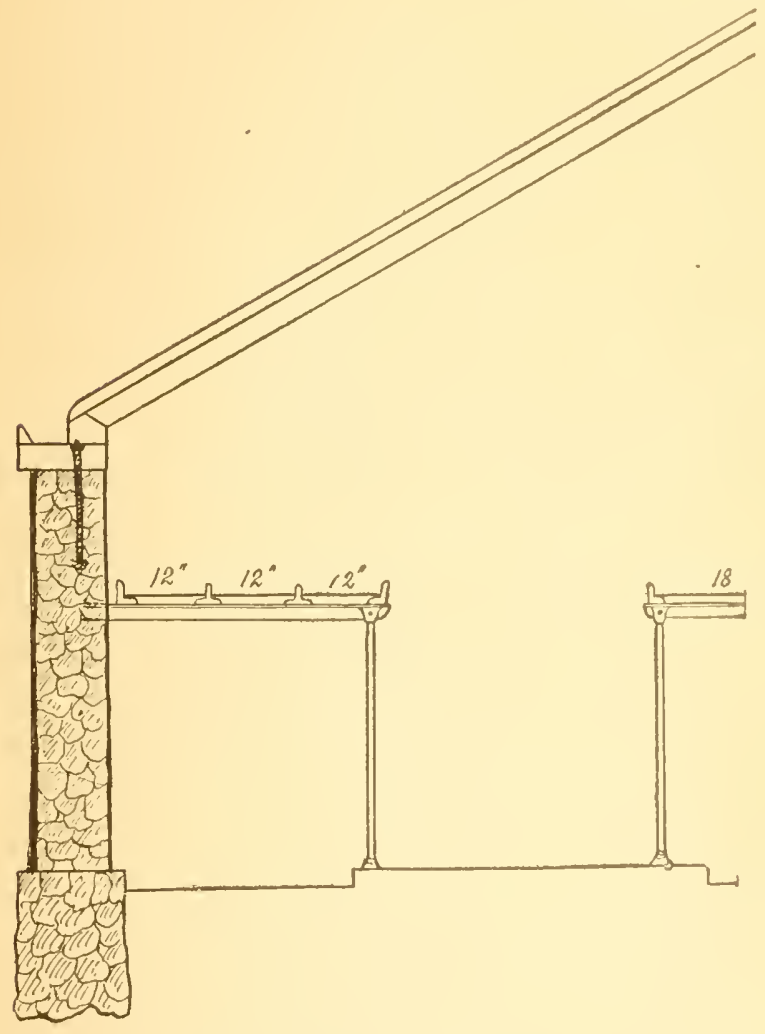

FIG. 53. ATGLE IRON BEXCH.

one-half inch angle iron $(G)$ for the front and back, and two intermediate one and one-fourth inch T iroms $(I I)$. Using twelre-inch slate, or tile, for the bottoms, the bench will be three fect and two inches wide. Fur the 
legs, one inch gas pije ( $E)$, or one and one-fourth inch 'I' iron can be used. 'The gas pipe ean be flattened at its mper end and bolted to the cross bearers, or it can be inserted into a casting (Fig. $14 F$ and $F^{\prime \prime}$ ), which can then he holted on. With snch a easting at the top, and a flat plate for the log to rest in at the bottom, a very neat hench can be made. If sides are desired to the benches, larger angle iron can be used for the onter elges of the benches, say three by two inches, or three to five-inch strips of bourd can be used, and held in place either ly the edges of the angle iron, or by means of serews jut through holes in the angle iron.

\section{BEXCII BOTTOMS.}

The bottom is, as a rule, the first portion of the bench to decay, and if any jart is to be of indestructible materials, this should be the one. 'The most satisfactory

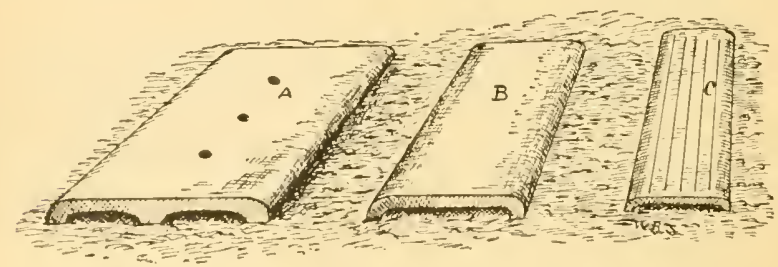

FIG. 54. TILES FOR BENCHES.

beneh bottoms, in erery way, are some of the forms of "bench tile." 'They are more or less porous, and provide botli for drainage and for a thorongh aeration of the soil. Those invented hy W. P. Wight, of Matison, N. J., seem partieularly desirable. They can be made of any size desired, although about twelve by six inches secus a good one, and differ from most of the others in luaring a row of holes along the center (Fig. 54 A). T'he form shown in Fig. $54 C$ is fire inches wide by twelve long, and Fig. $54 B$ represents a tile seven by 


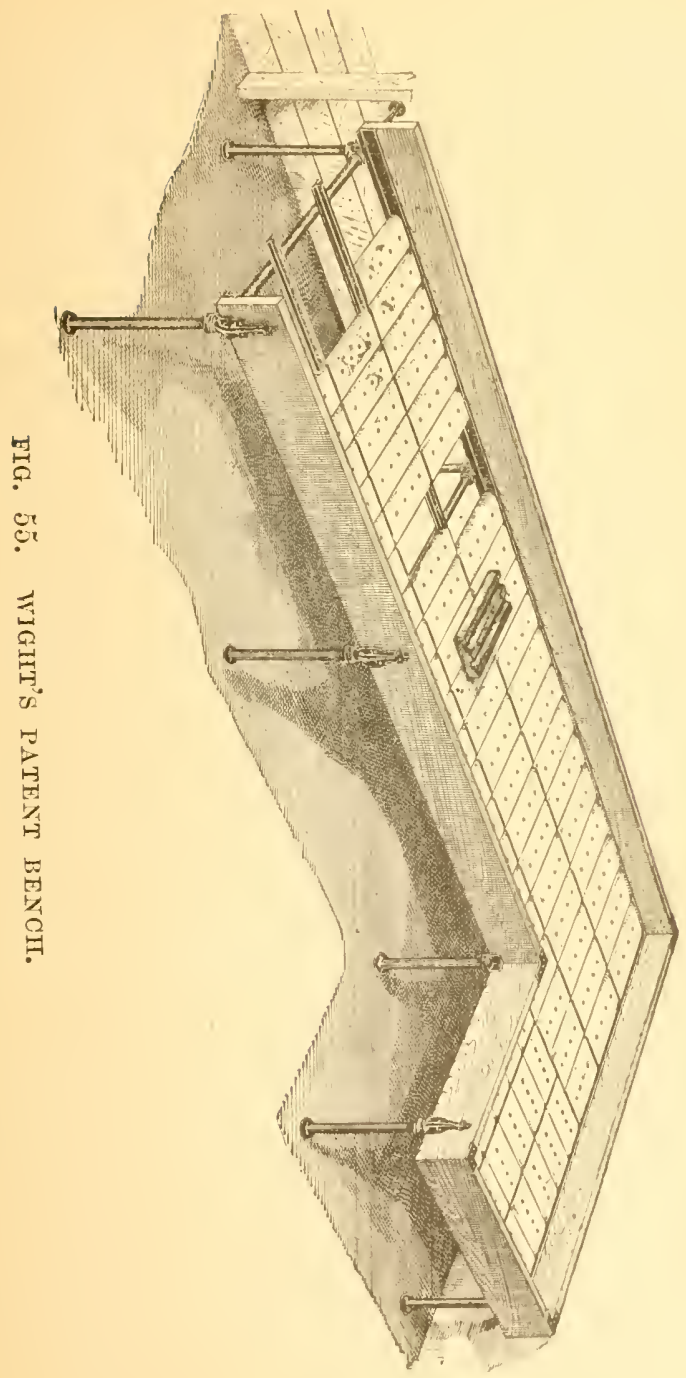


twelre inches, buth of which are manufacturerl for "fireproofing" the structnral iron in molem fireproof blocks, lut amswer very well for bench bottoms. By leaving spaces between the tiles, ample drainage ean be secured. Mr. Wight has inrented a bench (Fig. 5.5) to be used with his tiles.

For the talles in the show house, or conservatory, upon which lirge plonts only are placed, large slabs of slate, of the full width of the bench, may be nsed without ans covering. In the growing houses some corering for the slate is desirable, and smaller sizes mar be used. Heary roofing slate, about twelre by eighteen inehes in size. can be eheaply obtaincd, and, with a corering of coarse gravel, makes an excellent plant tab]e. When used as bottoms for the tables in rose lonses, and

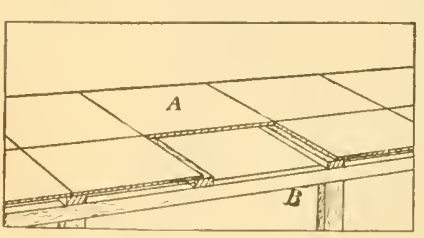
for entting beds, they are less satisfactory than bench tile, as they allow of but imperfect drainage and aeration, and the soil and sand soon become sonr. With careful watering the FIG. 56 .

WOOD AND SLATE BENCH. injury will be somewhat lessened, but the tile will be fonnd more satisfactory. In Fig. 56 will be seen a method of using sliete for bench bottoms, with wooden supports.

The use of boards for beneh bottoms may be eeonomical where lumber is cheap, and the other materials expensive, lut the more chrable materials will generally be preferialle.

SOIID IBEDS.

For growing many erops the so-called solicl bed will be resirable. These are of the same widthe and in the same places ats the raised beds, but, as a rule, are not as 
high above the walls. When the underlying soil is light and sandy, the application of alput six inches of prepared eompost will be all that is recpuiresl to malke them, except the erection of barricrs of wook or lorick to keep the soil in place. It is generally necessilly to provide some lind of drainage, and for this pmrpese threeineh drain tiles have been found exedlent. Jy placing them two feet apart and eight inches below the surfince, across the beds, ample drainage will be provided, and the warming and acration of the soil will be promoted.

\section{CHAPTER XIV.}

\section{PAINTING ANIJ SHAUING}

In order to preserve the wood from decay, and the iron work from rusting, the materials shond he covered with some substance that will render the woulwork water proof, and prevent the oxidation of the iron. There are on the market many patent praints that may be suitable for certain purposes, but very few of them will prore satisfactory for greenhouse painting. If pure white leatd and linseed oil, with a small amount of Tapan, are used, the results will be as satisfactory as can be obtained from any mixed paint, and as the (orering ol the framework of a greenhouse with sume print illat proved worthless for the purpose would lead to a large expense, it is better to talke sumething that is known to be good, than to experiment, with materials that, thongh apparently cheap, may prove dear in the cucl. 'T'here are sereral low priced brands of so-called "white leatl," that are composed. largely of zine and hatytil, and if these are used the paint will peel off within al year. 
If the houses are to be painted white, a little black shonld be added to take off the glare. Howerer, some other light color may be preferred to white, and a pleasing one can be made by adding yellow and a small amount of green, producing a very light shade of green. With darker trimmings upon the honse, this will be found quite satisfactory. While it is desirable to use pleasing tints for painting the greenhouses, preserration of the timber is the main object to be sought.

\section{PAINTING THE GREENHOUSE.}

The priming coat should be given before the house is erected. As soon as the parts hare come from the mill, the joints shonld be made, as far as is conrenient, and, if possible, the woodwork shonld then be soaked in hot linseed oil. A long tank should be made, and by placing the oil in it the parts can readily be dipped. If steam pipes can be run throngh it, all the better. When this cannot be done, the woodwork should be given a thorongh priming coat. The aldition of yellow ochre, or some similar material, to the oil, will be of adrantage.

In putting up the honse, too much pains cannot be taken in coating every joint with pure white lead paint. The arerage carpenter will not see the advantage of this, but a coat of thick paint shonld be insisted upon.

As soon as the framework is np, a second coat should be giren it. Our best greenhouse builders use two coats of paint for commercial, and three for private establishments. If only two coats of paint are to be given, every crack and nail hole shonld be filled with good putty before the second coat is applied, but, if a third coat is to be griven, the puttying should be delayed until the second coat is dry. When three coats are to be giren, it will he easiest to apply the last coat to the interior of the honse before the glass is set, althongh it would serve to hold the putty in place under the glass if 
it were applied after the glazing is completerl. I'batever the number of coats, the last one to the exterion should not be given until the glass has beens sot, ats then any crack that may remain at the sides of the panes can be filled. and the roof will he made water tight. 'The putty would also become softenerl, and womlel work ont were it not painted.

In drawing the salsh, on the exterior, the paint should be rather thicker than is used for ordinary painting, and it is an excellent iden if it is chawn out mon the glass for, perhaps, an eighth of an iuch. In this way, the paint will serve as a cement to holit the prunes in place, should the other fastenings becone displacert.

\section{IREPAINTIXYG.}

Whether two or three coats of paint are giren the houses at the time of erection, inother should be applied after one year, to the exterior, at any rate, although when three coats hare been nserl the painting of the interior may be delayed another year. In order to keep a greenhouse in the best repair, one coat shonk be grisen to all exterior wood work each year, and to the interior every second year. This frequent application of paint is made necessary by the fact that, if cracks open at any place, water will enter, and the rapid dccaly of the woorlwork will follow. If painting is long delayed, cracks large enough to admit water often open between the glass and the putty, and the latter, becoming softened, is washed ont. Through the openings thus formed, heat will escape, and water can gain entrance.

\section{PAINTING IRONWORK, PIPES, FTC.}

Iron houses also require frernent painting, not only in order to preserve the material, lunt to jurerent the rust that forms if the ironwork is not kept coated with paint, from discoloring plants, walks, woodwork, and 
auything else that it may fall upon, with the drip. All ironwork that forms part of the greenhouse structure proper, should be of the same color as the roodwork. When irom tables are used they should be kept well painted, using some color of asphalt or Japan paint,black asphalt being eheap and quite durable.

For the sake of the improved looks, to say nothing of increasing their durability, the heating pipes should also be painted. While asphalt will answer for this purpose, it is known that a larger amount of heat will be radiated from them if of a dull color, than if they are smooth and glossy, and the efficiency of the pipes will be increased by applying a mixture of lampblack and turpentine. The durability of the paint will be improved by using linseed oil, but it will have a glossy appearance, and if oil is used it should not form more than one-half of the mixture.

\section{SH.IDING.}

In order to keep down the heat and prevent the burning of the foliage of the plants, it is desirable to, in some way, obstruct the entrance of the heat lays. For some classes of plants a permanent sliading is desirable, and this can be secured by the use of fluted or rough plate glass. For most purposes, however, a temporary shading only is necessary, and some form of wash applied to the glass is commonly used to give this, when shading is necessary throughout the summer.

The application of lime or whitewash, either by means of a large brush or syringe, is a cheap way of shading the honse, and is commonly used by commereial florists; but it is lurdly satisfactory, as, when thick enongh to keep out the heat rays, it obstruets too mnch of the light. One reason for this is, that if a coat of the proper consistency is given, it frequently peels off in spots, and when a second application is made, to cover 
these openings, it is too thick upon the other purtions of the glass. 'This wash, too, has a glining applearance, that is not pleasing to the eye.

Perhaps the most satisfactory shading is made hy the nse of either white lead or whiting, in gasoline. i very small amount of lead,-porhaps a teaspoonful, will suffice for a gallon of gasoline, but the rumentity of whiting required will be much larger. It will be best to make a thin preparation, and, if fonnd to be too thin, more of the lead or whiting cam be added. This wash can be put on in a fairly satisfactory mamner with at syringe or small force pump, but it can be sprearl more evenly and with greater economy of material with a lirge brush, and, where the appearance is considered, this will be a better way. It is generally desirable to put on a thin coating early in the spring, and add a second one in May or June. If not put on too thick, the fall rains and frosts will loosen the shading, and it will disappear as winter comes on. If this does not take place soon enough, the roof can be wet down with a hose, and any surplus rubbed off with in stiff brush.

\section{TEMPOLARY SIIADITG.}

For orchid houses it is desirable to have a form of shading that can be regulated at pleasnre. Some of the roller blinds answer well for this purpose, as they can be lowered on bright, smmny days, and drawn up at night, or in dull weather, to suit the needs of the plants. Cloth shades of light canvas or fine netting are less desirable, but answer very well. 'They can be nsed either ontside or inside the house, and, if hmog on curtain or awning fixtures, can be raised or lowered at pleatsure.

When orehids are snspended from the sash bars, the shntters, canvas, netting or other material used for shading, must be placed above the glass, and, to allow a circulation of air above the roof, iron rods should be so 
arranged that the shading material will be supported at a height of twelve or fifteen inches. By means of ropes and pulleys, the awnings can be easily raised or lowered.

For shading eutting benches, there is nothing better than light frimes covered with eotton eloth, although lath sereens are very useful.

\section{CHAP'T'ER XV.}

GREENHOUSE HEATING.

In our climate, most of the plants grown in greenhouses rerpure artificial heat to he maintained from six to nine months of the year, in order that natural conditions may be seeured for them. While some plants are not injured by exposure to thirty-two degrees, and thrive best at forty-five to fifty degrees, the so-called stove plants should have serenty degrees, or more, and to secure these temperatures in greenlouses various methods have been devised.

The crudest method is by slowly decomposing vegetalle materials, and allowing the heat to radiate into the air; 2d, the Polmaise system, which consists in passing cool air over a hot iron surface, and directing it into the house; $3 \mathrm{~d}$, by burning wood or coal in a furnace, and directing the gaseous produets of combustion through the liouse in a brick or tile horizontal chimney, known as a flue; 4th, which differs only in the method of conveying the heat, as in this it is taken "up by water and earried wherever needed in the form of steum, or by the circulation of the water itself.

The first method is only employed in hot beds and similar structures; the second, known as the Polmaise system, is not adapted for greenhouse heating, although 
when combined with the flue, it is sometimes nlserl. I, some sections of the comntry the flue is still minle nse of in heating small greenhouses, but by most florists steam or lot water is preferred.

Whatever the method of heating nsel, th: arerage person would consider, in making a selection, the first cost and the durability, the economy of fuel and attendance, and the eflicieney, both as concerns the amount and the regularity, of the heat supplied. Among other things that would be taken into accomnt, are the ovenness with which the heat would be distributed, the length of time the systems will run without attention, and the effect of each mpon plant growth.

\section{IIEATING WITH HOT WATER.}

This srstem was one of the first to be used fol the heating of greenhouses in modern times, and it is elitimed that the cireulation of hot water, is a means of eonreying heat, was nsed by the old Romans in wurming their dwellings. It went out of use, however, until $1 \% \%$, when a Frenchmin, Bonneminn, reintroduced it. Ancient as the method is, the hot water heating systems of to-day are comparatively modern inventions, and bear little resemblance to those used eren fifty years ago; in fact, the chinge has been so recent that many of the systems in use to-day are built on quite different principles from those constructed according to the latest ideas.

\section{HOT WATER IN THE EARLI DAYS.}

The Romans are believed to have used bronze circulating pipes, and the first pipes used for heating greenhouses were of copper, and measmed four to five inches in diameter. The heaters used were also of copper, and generally resembled an open kettle, resting upon a hrick furnace. From the kettle two four-inch pipus ran to the other end of the house, where they entered al colyer 
reservoir (Fig. 3). The pijes were perfectly level, and one left the heater at the top, forming the How, while the return entered at the bottom.

For thirty years previons to 1850 , the nsual method of heating greenhouses was similar to the one described abore, except that closer cast-iron heaters were nsed, from which cast-iron pipes carried the water about the houses, ending in large open expansion tanks or distributing reservoirs.

\section{MODERN IOT WATER HEATING.}

Modern heaters are made in hmndreds of designs, and while each is generally claimed, by its inventor, to surpass all others, it is a hard matter to decide which one is really best. 'They are made of both cast and wronght iron (small ones may be made of copper, zinc, etc.), and here, at once, arises a dispute as to the merits of the two materials.

'The wrought iron is more likely to rust and, during the long summer months, when they stand nunsed in the damp greenhonse stoke-holes, they often snffer severe injury. 'The wronght iron is, also, more injured than cast-iron, by the sulphurous and other gases of combustion and, for these reasons, it is claimed by some that cast-iron boilers will list much longer than those of wrought iron. 'This has certainly been the case with some heaters, but it has been due, in part, to the fact that many heaters have been made of common gas pipe, instead of the donble strength pipe which shonld be used. When this thin pipe is threaded, and the threads are not male in, the surface exposed is quickly eaten throngh. When no pipes smaller than one and onefourth inch are used, and these are double strength boiler flue pipes, the durability of the wrought-iron heatcrs will be increased. 
POINTS FOR A TOT WATER II EATER.

Aside from durability, simplixity, and compatcotness of construction, the following points in the make-up of the heater should be consilered: 1. 'I'he anomnt and arrangement of the direct heating (lire) sllrfice, and its proper adjustment to the grate area. 2. 'The arrangement of the water sections, or tulbes, and the virculation of the water in the heater. 3. Fise of eleaning the flues, and the arrangenents for shaking, dumping, removing the ashes, regulating the draft, cle. 4. The character of the joints, and the ease with which leaks can be repaired, and breaks mended.

If the first and second requirements are met, we may have a heater that is efficient and economical of fuel, but the points noted in the thire have much to do with the ease of firing and earing for the heater, while those in the fourth will be desirable in case leaks occur.

\section{ARRATGEMEXT OF THE FIRE SURHACE.}

It is well known that a surface arranged at right angles to the fire is nearly twice as efficient as one that is parallel to it. Unless this cam be secured, it necessitates a corresponding increase of the area of fire surface, which will not only add to the cost of the boilcr, but will render it more cumbersome, and increase the amount of cirenlation of water in the heater. When the arrangement is such that horizontal surfaces cannot be secured orer the firepot, the sime effect can be, in jart, obtained, if the direction of the draft is such that the flames are drawn at right angles towarls perpendienlar tubes. When this can be brought about, it aflords very effective heating surface, and is not objectionat)le; on the contrury, it is desirable to so arrange the draft and flues, that the products of combustion are carried in as indirect a course as is possible, and yet secure a proprer draft for combustion, remoral of smuke, ete. By cloing 
this, and by repeatedly bringing this heated air in contact with the water sections, we ean finally lower the tempeliture down approximately to that of the water. 'The nearer we approach this, the greater economy shall we find in the heater.

While it is of importance that heaters have ample grate areas and a good draft, the amount and arrangement of the fire surface is of equal importance. To obtain the best results, the grate area and fire surface should be carefully adjusted; but for this no general rule ean be given, as some heaters have their surface so nicely arranged that the heat liberated upon one square foot of grate area can be taken up by fifteen square feet of heating surface, while in other heaters thirty-five or forty fect of fire surface will be insufficient. In a general way, a square foot of grate surface will supply two hundred and fifty square feet of radiating surface, but, as a lule, it will be more economical if two hundred square feet of radiating surface is taken as the limit.

2. IRRANGEMENT OF THE WATER SECTIONS AND TUBES.

The arrangement of the fire surface will, of course, determine the position of the water in the sections and tubes, but will not, necessarily, regulate the direction of the flow, the amount of water, ete. 'The eireulation of the water in the ordinary heaters is rertical, horizontal, in drop tubes, or a combination of two, or even all three of these ways.

The cireulation in the heater should be as short as possible, and it is better to have the water spread out in thin sheets, and with the arrangement such that the water is divided into a number of portions, each of which makes a single short circulation, than it is to have the entire mass of water that flows through the heater wamed by conveetion, or compelled to pass in a zigzag 
conrse throngh a number of different tubes and serofions. In this way, foo, the friction will be decreased and the cureulation improved.

So far as circulation goes, the rertical tulue touds to reduce friction, and to this extent it. is assirahle. (1)n the other hand, the friction proulneed by one rirenit of the water in a horizontal soction is so slight that it is often more than comnterbalanced by the incroased afficiency of the horizontal fire surface.

The drop tubes nsed in many boilers present a rery good fire surface, as the ends are directly wer the grate. and, as the water circulation is verticil, they form a very effective portion of the hoater. When large tubes are used there is little danger of their filling up with sadiment, and the principal objection that can lo urged against them is that the water cannot be drawn off from them.

Another thing that it is desirable to scenre, if possible, is the blinging of the prodncts of combustion, als they are about to leave the heater, in contart with tubes or sections containing the return water. It can be readily seen that water at $1,5^{\circ}$ coming back in the rotmons, can still take up heat from gases that hare been in contact with iron snrfaces that are $200^{\circ}$ or more. In this way considerable heat will be saved that would otherwise pass up the smoke pipe.

3. ARRANGIEIENTS FOR CLEANING ANB FIRING.

It is self-evident that anything that alils to the convenience of a heater will be desirable, and the matter of shaking, dumping, and regulating of clafts should he considered. Of especial importance, howerer, is the matter of eleaning the flues. Unless ther is a great loss of heat, a heater camnot be male in which there will not be, in some portion, an acenmulation of soot, and if this is upon any of the lieating surfaces it should ha 
frequently remored. A heater in which the flues cannot be kipt clean is of little vilne, and the greater the ease with which it can be done, the leetter. If the surface requiring deaning is small and easily cleaned, the actual tromble womid he rery slight, and althongh the flues of some heaters are practically self-cleaning, their heating surface may be less effective, which would more than comnterbatance the cleming required by the other.

\section{SIMPLICITY OF CONSTRLCTION.}

Many heaters are quite intricate in their construction, and the different parts are fastened with screw joints, or, as is more common, the joints are packed and the parts are drawn together with bolts. Everything else being equal the fewer joints there are, the less ehance there will be of leaks, and in selecting a leater this should be considered, as well as the character and location of the joints. The screw joint is perhaps the surest, but it has one ojection, particularly in wronghtiron heaters, as the threads tend to increase the corroding influence of the sulphur gases. Packed joints are fairly reliable, but it is desirable that they be easy of access, and so arranged that they ean he repacked should serioms leaks occur. Some of the sectional heaters are so constructer that, if one section is broken in any way, it can be cut ont of the circulation, and the heater can then be used withont it until the section is mended or an new one proenred. In ease the section has to be replaced by another, the arrangement should be such that the change can be readıly made.

While all of the points enmmerated above are deemed desirable in a heater, it can still be of great value if it does not prossess one or more of them; but in selecting a heater, while the fact that one or more important features were lacking might not prevent its being chosen, it wonk be well to talke the one which comes the nearest to possessing them all. 


\section{CHAPTER XTI.}

\section{PIPES AXD I'IJITH.}

In the old styles of hot water plants, the pipes were of four-inch cast-iron, put together with shoulders and packed joints, and with large expansion and distributing tanks at the ends of the runs, and at the points where the branches left the main lines. In the modern system two-inch pipe is the largest used for the coils, while one and one-fourth inch and one and one-half inch are fresferred for short runs.

Some of the adrantages of the modern system may be stated as follows: The lengths of pipe are from two to nearly four times as long, and can be sereweel together instead of haring to pack the numerons joints; there is less chance of leaky joints or of cracked pipes; althongh the cast-iron four-inch pipe has only twice the radiating surface, it is necessary to provide fonr times the amomnt of water for the circulation that the two-ineh contains: on accomt of the size and weight of the four-inch pipe it is necessary to lave them low down under the benches but little above the level of the heater, while the small wrought-iron pipe can be carried in the very angle of the ridge if desired, and thens a far more rapin circulation can be maintained than with large pipe; the large pipe carrying a large quantity of water and giving a slow cireulation, is at a much lower temperature, particnlarly on the retnrms, and a smaller radiating surface will suffice when small pipe is nsed. so that some flurists count a two-inch wrought-iron jije equivilent in heating capacity to a four-inch calst-iron pipe; from the 
large pipe the amount of heat given off on bright, sunny days when it is not needed, will be from two to four times as much as from small ones, and this will necessitate increased rentilation and perhaps cause serious injury from drafts of cold air, to say nothing of the loss of heat; finally, in addition to the points enumerated abore, the small pipes will give a much more economical circulation than the large ones, they can be carried to a much greater distance, and the heat will be far more eren.

It has been claimed that the large piping is safer to use, as it will hold the heat longer. This is undoubtedly true, if the fire is allowed to go ont; but, with a wellarranged system, a regular, cren temperature can be maintained with small pipes for ten to twelve hours, on mild winter nights, and seren to cight hours on sevcre nights, which is as long as it is desirable for the houses to go without attention.

The term "upwari pressure" is often nsed in speaking of hot water circulation; but although it is a convenient one to nse, it really has nothing to do with the circulation, as there is no pressure of the kind exerted. Hot water has a dounued pressure equal to its own wright, and the only reason for circulating is that the wright of the hot water is more than balanced by the weight of the cooler water in the pipe, and it passes upward, pressed out of the way by the heavice cool water which pushes into its place. The same thing can be scen in a kettle of water where the water in the center is warmed and is pushed to the top, while the cool water from above takes its place. The method of circulating in a hot water apparatus can be best understood by reference to one of the old styles, as shown in Fig. 3 (a represents the heater, o the expansion tank, and $g$ the flow and return pipe). Let us suppose that a fire is built under the boiler, and that the water contained thercin 
becomes warm, the same as in an wrdinary hettle. It is known that water when warmed from 3!' to "2l" increases in bulk one twenty-fonrth. If the watcr in " is warmed up to the hoiling point it has dereneast in weight, per cubir inch, one twenty-fourth. The watcer then in $e$ is one twenty-fourth heavier than in a, and, to establish an equilibrim, the water in $\rho$ will prass along the lower pipe to $a$, crowding the lighter water into the npper pipe.

If the heat is continned, other particles are set in motion the same way, and the rapidity of the cirenlation will increase nntil it is balaneed by the friction. 'T'he circulating force is governed by the eomparative woight of the warm water in the different parts of the system. The pressure of the water varies with the height of the colnmns, as well as the temperatmre of the water. If the height of the columns is increased, the diffurence between the weights of the two columns will be increased in about the same ratio, and as this difference in weight is what canses water to circulate, the reason for the success of the overnead system of piping can be readily seen. 'The same effect conld, howerer, be secured were it convenient to do so by lowering the heater.

There has been considerable discussion for many years as to the best way of rmming the pipes, but even now very few persons agree as to the proper method of arranging them.

\section{HOW SHALI TIIE PIPES SLOPE?}

Among the rarions methods are the "np-hill," "down-hill," and "level," and these are shown in Lig. 5\%" 1,2 , and 3 ; the last, however, is not desirable when small pipes are nsed. In each ease the height of the flow pipe at the point where it starts to make a cirenit of the house is six feet above the bottom of the boiler. but in the first case the pipe rises one fout in prasing through 
the honse; in the second it falls a foot, and in the third it does not change its level. In changing direction at the farther end, a foot fall is marle by each pipe, and on the return a fill of one foot is malle by the first and second systems, while the third remains at the same height mitil it has nearly reached the heater, when it drops to the level of the bottom of the heater.

The "pressure" is determined by the relative weight of the water on either side of the highest point of the

(1)

$(*)$

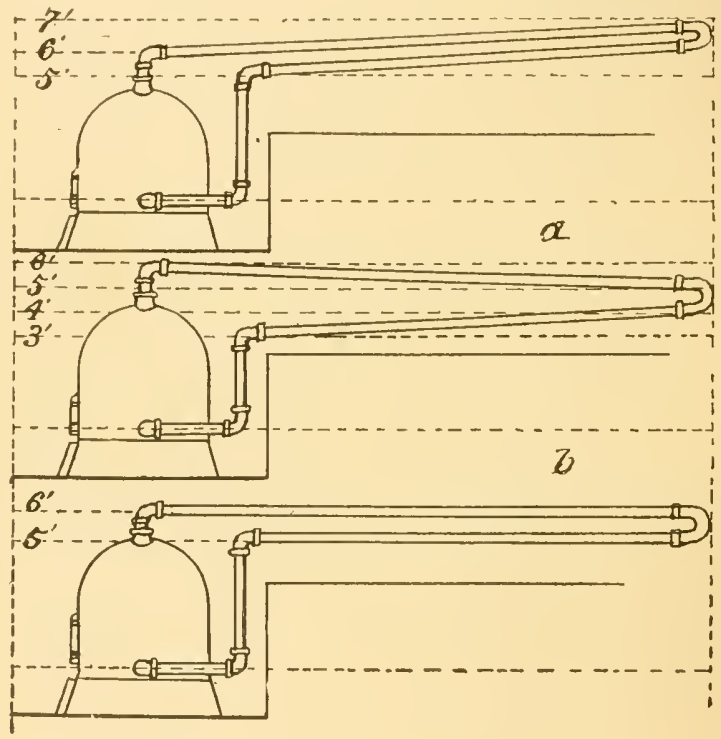

FIG. 5\%. THE SLOPE OF THE PTPES.

system, and it wonld have been a fairer comparison had the flow pipe fol the "mp-hill" system left the heater at a height of five feet rather than six, as the highest point in each system would then have been six feet above the bottom of the boiler. Trhen the size and the length of the pipe, the conncetions, ete., are the same, the system 
that is arranged to give the greatest differenee betweren the weights of the water on cither sille of the highest point, will have the best circulation, everything else being equal. For convenience let us consider that in cich system the "flow" pije extents from the beater to the highest point of the piping, and the returns extend from that point back to the boiler, entering at the botiom. To secure a good circulation, the water in the flow pipe should be as light (hot) ats prosible, and, that it maly not be subjected to cooling influences, the pipe should be as short as possible. If the flow pipe is short, then the highest point in the system must be near the heater.

In order that there may be a differenee in the weight of the two columns of water, that in the return pipes should be as heary (cool) as prossible, and this cam be best secured, everything else being equal, if the listance is considerable. Turning to the ilhstration we shall see that the highest point in ( $(2)$ and (3) is direetly orer the heater, while in (1) it is at the extreme end of the system ; the return in (1) is only one-half as long as in (:2) and (3), so that the cooling will be only aljout une-hait ats great.

As we wish to keep the water in the pipe hetween the heater and the highest point of the system from cooling, a large pipe should there be nsed, while, als it is desirable to conl off the water in the returns, the remainder of the system should be of small pipe. Considering the arerage temperatme of the water in the flow pipe to be $200^{\circ} \mathrm{F}$, and that in the returns $1 \% 0^{\circ}$, a culbe foot of the latter will be one-eightieth heariel than at cubic foot of water at $200^{\circ}$. If a pipe one foot high contains one pound of water at $200^{\circ}$, the same pipe will hold 1.0125 pounds of water at $1 ; 0^{\circ}$, aml were the two united there would be a "fressure" of .0125 of a pount. Were each pipe ten feet long, the water in one would weigh ten pounds and in the other 10.1\%5 pmonds, and there wonld be a pressure of an eighth of a lound, 
while at eighty feet there would be one pound pressure, or eighty times as much as at one foot.

It will thus be scen that the pressure increases with the height of the columus. As we wish to have as much weight as possible in the returns, they should be brought back to a point near the heater at as near a level as possible, and at the greatest convenient height. As just shown, if a flow pipe is filled with water at $200^{\circ}$ and we consider it to weigh one pound for each foot of pipe, there will be a pressure of .125 of a pound from a returu filled with water at $170^{\circ} \mathrm{F}$, if the pipes are each ten feet high. This would be the pressure then in a lot water apparatus nuler the above conditions, $i$. e., the flow pipe rises ten feet above the heater, and passing through the house returns to in point over the heater, without changing its height.

On the other hand, suppose that after passing to the farther end of the house it drops perpendicularly five feet and returus at that level to the heater. There will then be a head of five feet where the water has a temperature of $185^{\circ}$ and of fire feet when it has cooled down to $180^{\circ}$, and we should have

$$
\begin{aligned}
\left(185^{\circ}\right) 1.005 \% \times 5 & =5.0285 \\
\left(1 \% 0^{\circ}\right) 1.0125 \times 5 & =5.0625 \\
10.0910-10 . & =0910 \mathrm{lbs} .
\end{aligned}
$$

As compared with a pressure of 0.125 of a pound when the return was ten feet high, this shows a pressure of only .0910 of a pound, or a loss of .03t of a pound as compared with the other method. In order to allow the air to escape, the pipes camnot be carried on a level, and henee as the next best method they should be given a gradual fall thronghont their length, taking pains to keep them as high as possible in order to seenre pressure. While it will be best to have long straight luns, with the same slove throughout, if necessary there may be vari- 
ons chatuges in the leve] of the pipes, and cilroulation cinl

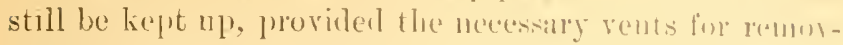
ing the air are provided, and the pressute, as explationd above, is sufficient to orereone all friction.

In some cares the down-hill piping (?), fig. is. cammot be used to anvantage, and the mp-litl sistem (1), will serve the purpose. With the slight allitence in level that can be secured in greenhonse huating, particularly if the pipes are under the bench, the diflerence in efficiency will hardly be noticeable. Theoretically, the lerel piping, as in Fig. $5 \%(3)$, gires the greatest plossure; the down-hill system comes next, and the mp-hill piping gives the least pressure, althongh, as piped in Fig. ji. (1), the pressure with a cuil soren fuct ligh is about the saune as with the level piping in a coil six fect hight.

\section{OTER TS. IXDER BENCH PIPN(T,}

It is muquestionable that if all the pipes are above the benches, the circulation will be better than if all. or even a part of them. are below. It ane or two pipes are placed upon each plate, and the others near the jurlins, the amomt of light obstructer will be comparatively small ; the heat, however, will not be as well distributed as if the pipes are spread out below the benches. Experiments to test the matter have shown little if any difference in the results, whether all of the pipes are albore or below the benche:, but with the feed pipe above the bench and the coils below, there is an imporovenent in ciremlation, and fully as good if not better growth of plants as when all are below, and this plan shonld be used whenever practicable.

The principal benefits from overhead piping are (1) the melting of snow atul ite on the roof, (:) talking the chill from cold drafts of ail and (3) dryiner otl the piants after syringing, all of which will he latrely donce by the orerhead main. 'The vrertead system, moreorer, 
earries the coils higher than they are in the underbench system and a more rapid circulation is seenred.

Some houses have been piped with the flow pipes under the side benches, and the returns above the benches. While this gives a good cirenlation, better results can he obtained if the pipes are placed in the same way except that the orerhear pipes are attached to the How pipe from the boiler, and those under the benclies to the returns. The returns under the bench can either be of the same size as those above, or of a larger sizc.

\section{CIIAP'TER XVII.}

SIZE LND AMOUNT OF PIPE.

The size of pipe best suited for the coils depends upon the length as well as upon the height of the coils. Considered as radiating surface only, one-inch pipe would be preferable, but, except for very short runs, since the friction increases as the size of the pipe decreases, a larger size should generally be nsed. Inch and onequarter pipe can be used to advantage in coils not orer forty feet long, and if the height is snfficient, the length may be considerably inereased. For coils up to serentyfive feet in length, one and one-half inch pipe will be entirely satisfactory. 'Two-inch pipe will work well up' to one hundred and fifty feet, but it is better in all houses over one hundred feet long to use two or more short eoils of one and one-half inch pipe. In this way, by having proper flow and return pipes connected with the evils, honses three lundren feet long can be heated with hot water.

If it ean be so arranged, however, it will be better to have houses one hundred and fifty feet long on either 
side of a potting shed and connecting passitere, which will really make houses three hundred foet long while, with the heater located at the eenter, they will be only one lunndred and fifty feet in length so far als the heating apparatus is concerned.

SIZE FOR MAINS.

In determining the size for the feer pipes the length of the house and the height that the coils will hatve, should be considered, ats well ats the number of sylure feet of radiation to be supplied. For houses of arerage length, and with the average leight of the coils six feet above the bottom of the licater,

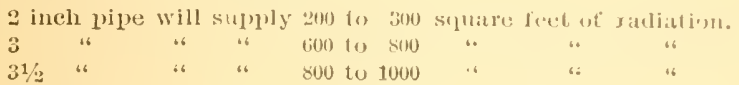

With long coils and light pressure these fignues will need to be slightly reduced, but if the runs are short and the coils elevated they may bo increased fifty per cent.

TO ESTIMATE R.IDIATION.

In computing the amount of radiation requirer for a house, the climate, exposure, construction of the house. and the amomnt of exposed wall surface shomld be considered, as well as the temperature to be milintained. When the walls are high or poorly built, or if the roof is not tight, allowance should be made for it by adding to the glass surfice one foot, for every five feet of exposed wall, and a corresponding increatse for the poor glazing.

In most parts of the country we call reckon that

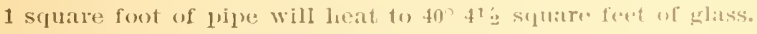

\begin{tabular}{|c|c|c|c|c|c|c|c|c|c|}
\hline 66 & if & 66 & 6 & 66 & E) & 1 & " & th & $\therefore$ \\
\hline 6 & 16 & 66 & " & 16 & $5 \%$ & $3^{1}=$ & $i$ & ." & $\cdots$ \\
\hline • & $\because$ & 16 & .6 & 16 & (j) & 3 & 66 & $\because$ & " \\
\hline 66 & .6 & .6 & 6 & 6. & $(i ;)$ & $21 ! 3$ & 66 & $\cdots$ & 66 \\
\hline 16 & 66 & 66 & .6 & +6 & To & 9 & 66 & 66 & 65 \\
\hline
\end{tabular}


While a slightly higher estimate would be safe, it is ceonomy to have an abundant racliation, especially for tropical houses.

In estimating the surface of wronght-iron pipe,

I inch vipe is ieckoned at .34 spuare foot per linear foot.

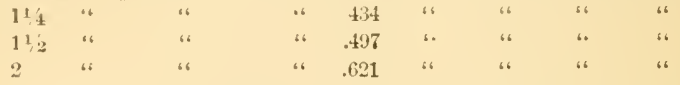

PIPING TIIE HOUSES.

In arranging the heating pipes we ean place them all muder the benches, have them all above the benches, or the flow pipes may be over the tathles and the returus underneath. If the under-bench system is used, the arrangement shown in Fig. 5s is a good one. When the honse is one hundred and fifty feet long a three-inch

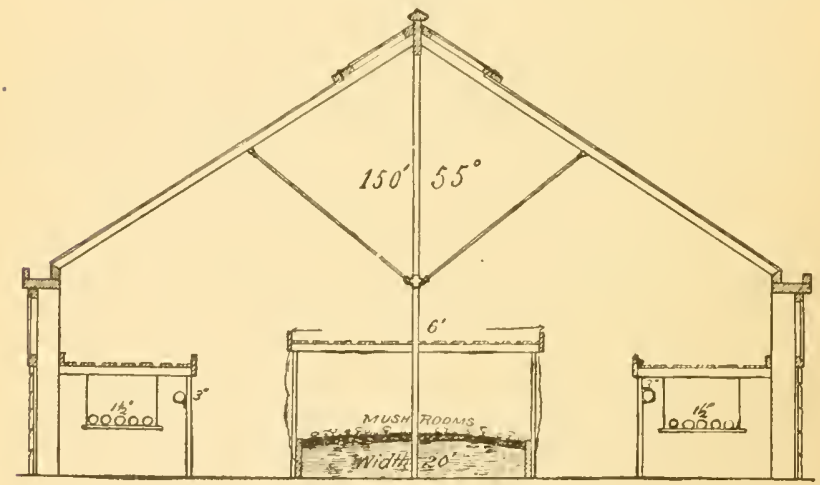

FIG. 58. UNDER BENCH PIPING, WIDE EVEN SPAN HOUSE.

flow pipe will be needed for each of the side benches. (A two-inch pipe will answer for a house one humdred feet long.) When the coils are of one and one-half ineh pipe there should be two, each serenty-five feet long, upon each side, or three of fifty feet each. With two coils 
the mains should enter the honse close to the bottom of the bench, and falling at the rate of one inch in twenty feet should pass to the midrlle of the honse, where al twoinch brameh shomld be taken off at the side by means of a hot water ' $\mathrm{T}$; the main should be contimed by mun of a two-inch pipe to the farther end of the honse, where it should connect with the coil.

In a house one hundred feet long the two-inch feed pipe should be rmu in the same waty its the above, except

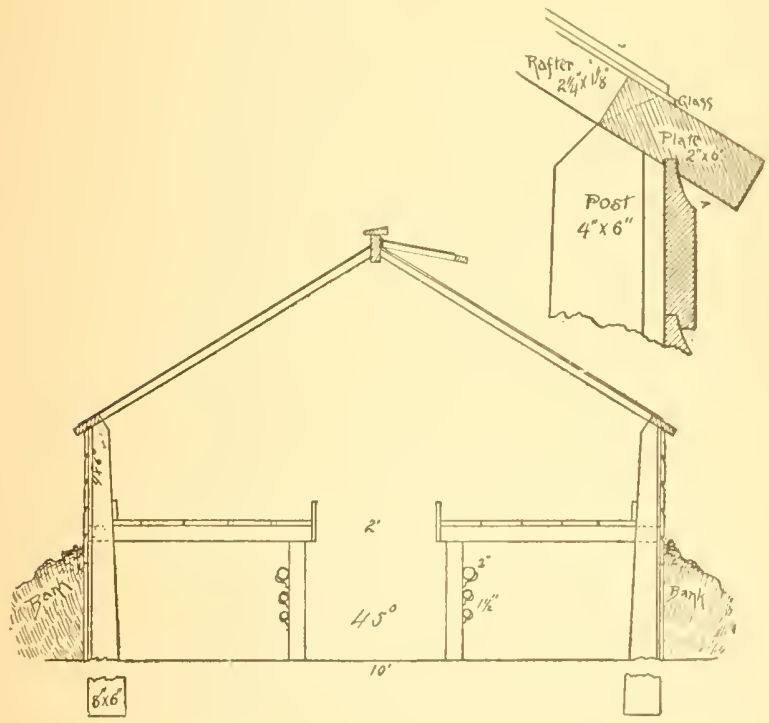

FIG. 59. UNDER BENCH PIPIYY TOR SIRROWV EVEX SPAN HOLSE.

that the branches should he of one and one-half inch pipe. If desirer, howerer, the coil can be of two-inch pipe, in one piece. The return pipes shonld fall towats the heater at the rate of one inch in ten or twelre fect. If the bench is too low to atmit of a morer fill of the 
flow pipe from, and of the return towards the heater, the flow may be given a gradual rise to the farther end, and thus a fall can be seeured for the returns.

Another method that will be preferable to either of the above when the beneh is high enough to give a fall, or if the return cam be placed below the level of the walk, is to attach the feed pipes to the coils at the end nearest the heater. 'The coils can then be given a

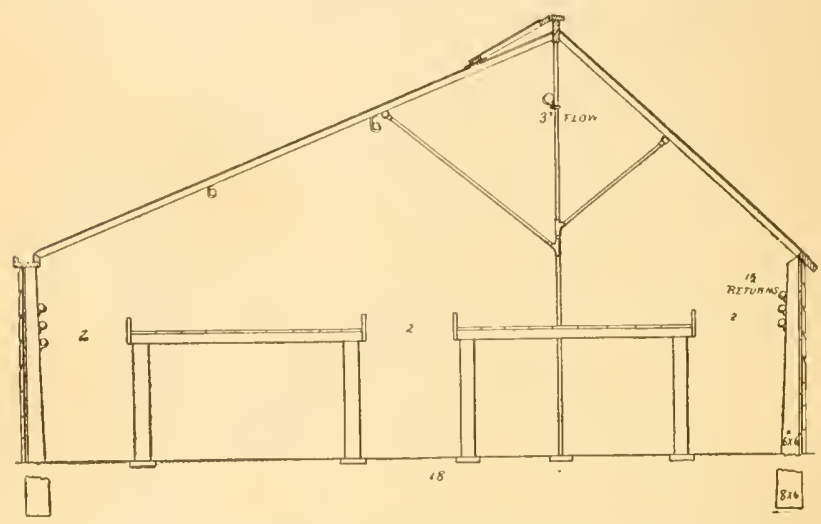

FIG. 60. OVERHEAD PIPINA, SHORT SPAN TO THE SOUTH HOUSE.

fall from the heater, and the returns can come back underneath. The arrangement of the pipes in a narrow even span house to be heated to forty-five degrees is shown in Fig. 59.

\section{OVERHEAD PIPING.}

In carnation and other cool houses where the amount of pipe is so small that it can be carried upon the plate and purlins, and particularly in "short-span to the south" honses, the overhead piping will perhaps be desirable. The feed ipe can be carried npon the ridge posts 
(Fig. 60), and the returns arranged as shown in the sketch, or the flows, as several small pipes, may he alonew, and the returns, as one or two large ones, below:

COMBINED OFERHEAI AND UNDER-BENCII PIPIAG.

For most eommercial establishments the alove arrangement will be preferable to having all the pines above, or all muder the benehes. One method is illustrated in Fig. 61, in which the main is carried near the ridge, and the returns in vertical coils upon the beneh legs. In the north-side propagating house, all of the

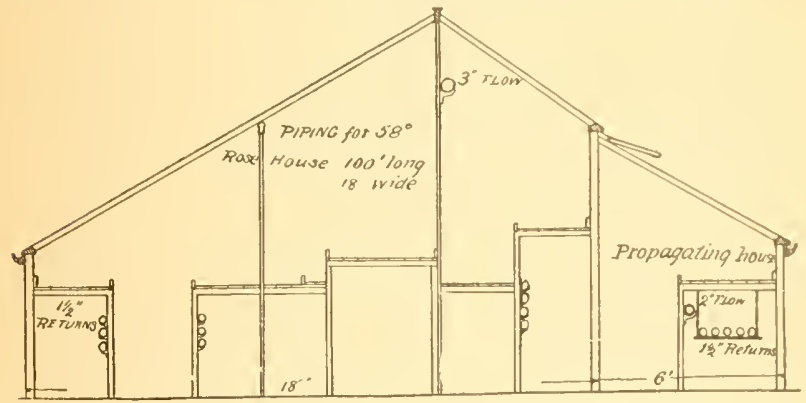

FIG. 61. COMBINED OTERHEAI) ANI TXUER-BENCI PIPING.

pipes are under the beneh. For an eren-span house one hundred fect long and twenty feet wile to be carried at sixty-five degrees, the arrangement illustrated in Fig. 6\% will give good results.

With a good fall, one and one-half inch pipes in the eoil can be nsed for a long rum, Jut it will generally be better to make two coils on al wille, each fifty feet long. At the middle of the homse, feed pipes (one and one-half ineh) ean be taken off to foed the first eoils, and the main can be extended as a two-inch pipe to the end of the house, where branch pipes can he connected with the other coils. Fig. 63 illustrates a methorl of piping a 
forcing house one hundred and fifty feet long and twenty feet wide that is to be kept at sixty-fire degrees. The coils, as in Fig. 62, are placed horizontally, which probably makes them more efficient than when they are arranged vertically. Fig. 81 shows a method of arranging the hoating pipes under the bezches that can be used when there is a bench across the farther end of the house. As the min is somewliat elevated, it has some of the merits of the combined system. It will be noticed that although Figs. 52, 63, and 81 are designed to illus-

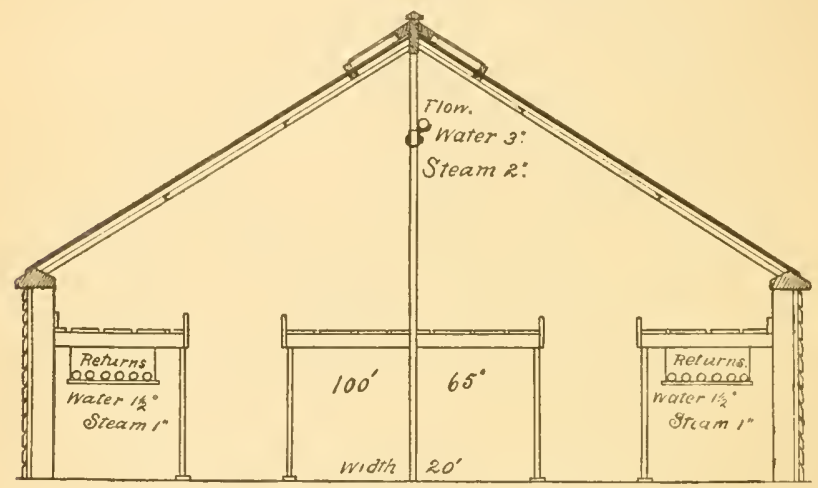

FIG. 62. COMBINED PIPINA, EVEN SPAN HOCSE, $100 \times 20$ FEET ; 65 1)EGREES.

trate methods of piping, they also show various ways of building the walls, ventilators, posts and braces, benches, ete.

PIPING NARROW HOUSES.

In low and narrow houses the same methods of pipung can be used, making proper reductions in the number of the pipes in the coils, and in the size of the main. 'Thus, for a span-roof house twelve fect wide and one hmudreil feet long, to be kept at fifty degrees, a twoinch pipe at the ridge will feed three one and one-half 
inch returns unter each beneh, or, if the muler-honch system is to be usod, a two-ineh flow on each sicle will feed two one and one-half inch ruturns. Sitill an.)ther method would be to use two one and onc-half inch flow pipes under each beneh, to feed the sime number of returns.

The heating surface will be most etheient if it is distributed evenly under the benches, but as they will then occupy eonsidemble space that could be occupied by mushroom beds (Fig. 5S) or for other purposes, it will generally be preferable to group them under the side benolies.

In building the eoils, cast-iron hearlers, or', better, manifolds built up of 'I's and nipples, can be used at one

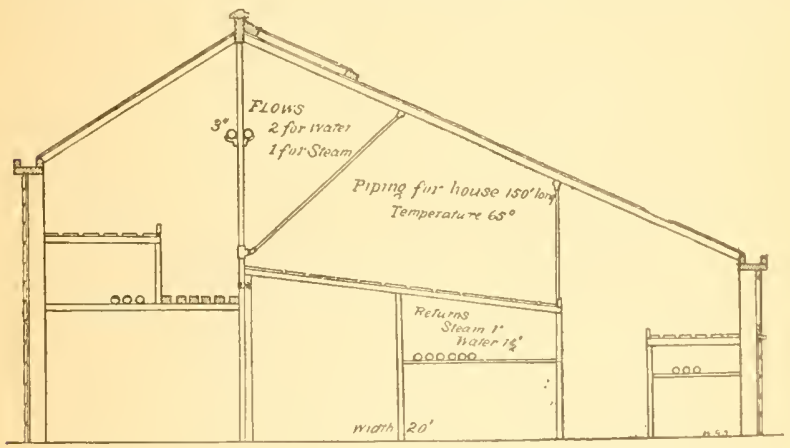

FIG. 63. COMBINED PIPINA FOR FORCING ILOLSE,

$$
150 \times 20 \text { FEET; 65 DEGREES. }
$$

end of straight runs, but on alccount of danger from the unequal expansion of the pipes, a mitre shomll be arranged if headers are to be used at both ends. 'T'he' coils can be carricd across the end of the house and and in headers at the center, to which branches from the feed pipe can be attacler, as in Fig. 64.

The orerhead mains can be fastened to the josts by means of cast-iron brackets, while unclel the bench they 
can be supported by pipe hooks mpon the hench legs. The rertical coils can be fastened in the same way, and the horizontal coils can be supporterl as in Fig. 63, or upon pieces of gas pipe suspended from the bench crossbearers by iron hooks, as seen in Figs. 58 and 62.

\section{VALVES AND EXPANSION TANK.}

In order to regulate the flow of the water through the coils, there should be angle or gate valves upon the returns, or "upon the branch feed pipes, and if it is desirable to arrange the honse so that heat can be shut off for

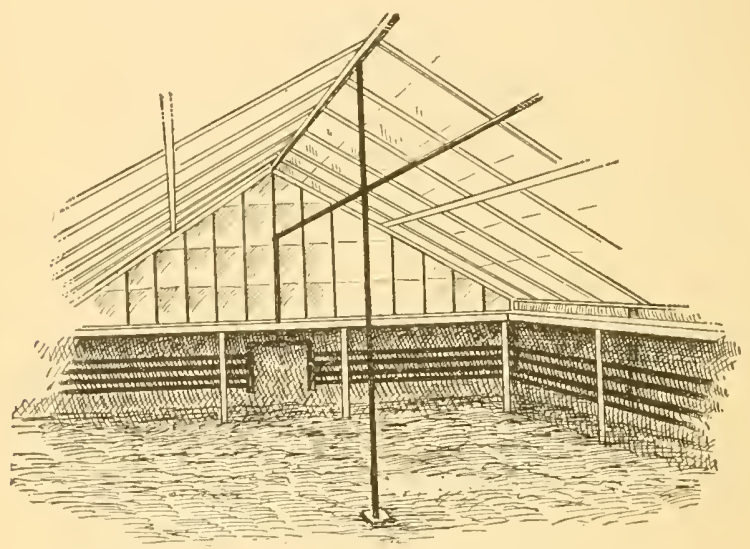

FIG. 64. ARRANGEMENT OF THE COILS.

a portion of the winter, there should be valves on both the flow and return mains where they enter the honse, with a draw-off cock so that the water can he removed.

The expansion tank should be raised as high abore the mains as possible, and connected with it (at the highest point, in case the piping is down hill), by a pipe from one to two inches in diamcter, according to the extent of the system. The elevation of the tank in no way affects the circulation, as it merely raises the boiling 
point of the water. The tank may he of galramizud irom. without a eorer, with the expansiom pipe rommerted with the bottom, and an orerflow pijo ittached abont fwothirds the way up the side, or a riveted boiler-iron chescre tank with the same connections and a water ganum om the sicle.

\section{HOT WATER TNDER-PIESSERE.}

When the down-hill system is mocel, many florists combine a closed expransion tank with it. The tank shonld be of boiler-iron with top and bottonn secrumly rireted on ; thus far it does not ditfor from those comimonly used in the open system. The only diflemen is that there is no vent in the top of the tamk, and that there is a safety valre on the orerflow, which, as in the open tank, earries the waste water to a dlanin.

The elosed tank has the same effect ats does the elerated one, and merely raises the point to which the water can be heated withont forming steam. One adrantage of this is that, When water is calrien at $22^{\circ}$. much less heating pipe is required than when it is only $160^{\circ}$, but a serious objection is that it nom has one of the faults of steam as, at this temperatmie, more heat will be carried up the chimney with the products of combustion, than when the watel is 180 ?. It is an excellent plan to have the honse supplied with suflieient radiating surface to maintain the required temperatule in the arerage winter weather with an open tank. but to hare the system protided with a safety-ralse, which conld be thrown on when it berame neessily, in order to keep np the temperature when the thelmometer erous down below zero.

Unless the dom-hill system, with the tamk at the highest point, is usel, air vents shomlil he providerl. wherever the pipe takes an npward tmpose at the highest

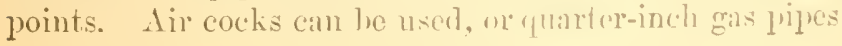


carricl abore the level of the expansion pipe will answer, and are preferable if the tank is not much elerated.

\section{NGES OF DIRECTION AND LETEL.}

If for any reason it becomes necessary to change the direction or the level of the pripes, it should be the least amount possible, and, in doing it, $45^{\circ}$ ells, redueing tees, etc., should be used. If necessary, the main pipes can be changed from their comse and rum orer or nnder an obstruction, and they can even be carried below the level of the heater, but it should not be done mnless there is an abmolant pressure. In all downward changes of lerel, the foree required to bring the water back to its original level will be in proportion to the cooling that takes place between the fall and rise. Every change in direction increases the friction and decreases the flow.

\section{CONNECTING THE DIFFERENT STSTEMS.}

If there is a range of honses to be comnected with one system, the arrangements will need to be such as will snit the conditions. If, as is rery convenient, the honses have a common head house, the heater can be situated in the center, and the feed mains can be carried along the wall of the head house, just above the doors that open into the greenhouses, and the branches can be taken off from this. The returns can be conneeted in much the same way, but the return main will be below the lerel of the coils.

\section{FOUR-INCII IIEATING PIPES.}

Althongh an expensive method of piping and heating greenhouses, many florists prefer to use four-ineh pipes. The pipes must all be nnder the benches, mpon substantial brick piers. If air vents are provided at frequent interrals the jipes may be level ; otherwise a slight down-hill arrangement will be preferalse. The joints should be packed firmly with oakum or tarred rope, with 
iron eement or l'ortlanel cement butwen the latyre. and at the onter alge of the joint. It the runs arre lung the pipes should rest on gils-pijpe rollers, that, explansion and contraction maly not break the joints.

\section{PIPING IN GENLRAI.}

The same generil rules as to the arrangement of the pipes apply to all kinds of houses, and will only need to be slightly modified to suit the rarions conditions. For large conservatories, particularly if the center of the house is filled with plants growing in the ground, it will be neeessary to have all of the pipes armangel in stateks along the sides, or, if desired, cast-iron rideliator's cin be used.

\section{CILAPTER YVIII.}

HOT WATER IIEATERS.

In the illnstrations of heaters presented, the selection was made with the illea of showing the construetion of different types rather than of alrocating the nse of

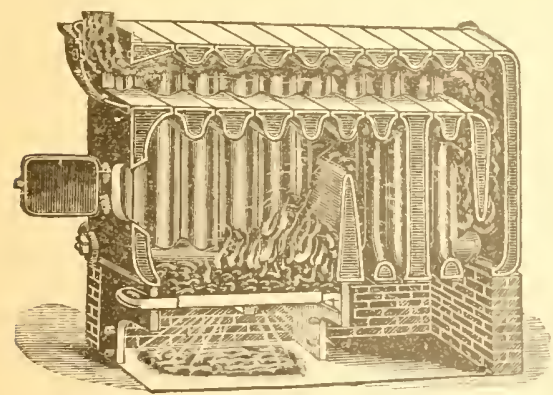

FIG. 65. CARMODY HEATER. any particular heater. While we can recommensl most of these from onr own experience, there are otleer heaters thit mily be fully als eflectire.

The Cimmody heater (Fig. (iij) is solected as the type of the verfiret sectional heaters. They are of a rery tmalle construction and, like others of the class, possces the importaut 
advantage of permitting the adrition of other sections, should it at any time become necessary. The water cir-

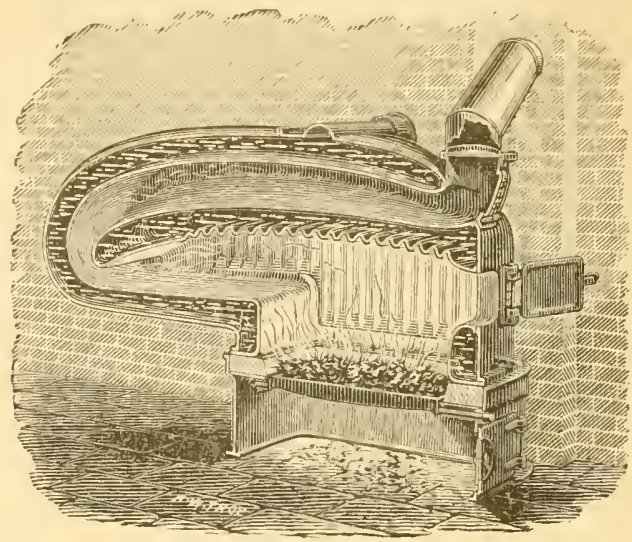

FIG. 66. HITCHINGS' HEATER.

culation, for the most part, is vertical, and the flues are arranged to give an effective heating surface.

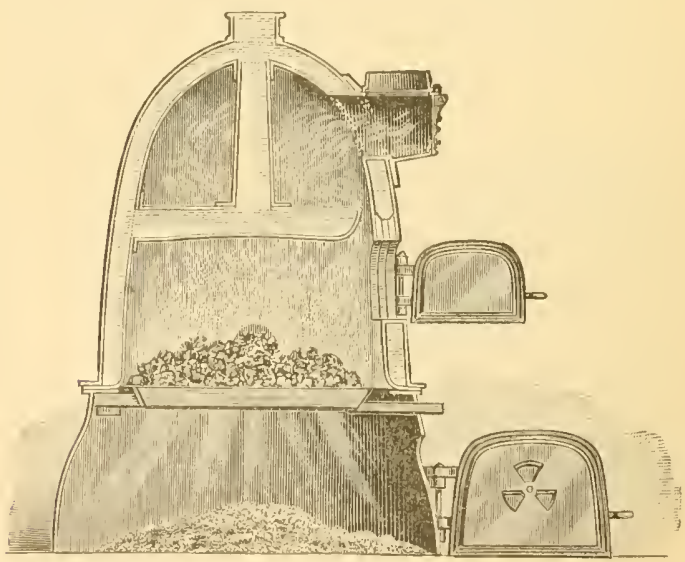

FIG. 6\%. WEATHERED CONICAT HEATER.

In some respects similar to the Carmody, but differing in being non-sectional, are snch well-known heaters 


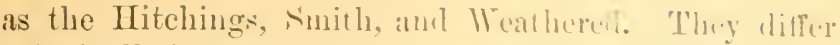
principally in the arringeunent of their firesurlares. In the Hitchings' corrugated leatter, of which al lomerimel-

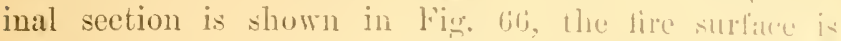
increased by meatus of ponderl communtions, while, in the Smith, the eorrugations are replaced by ' duite dere, square cells.

Few heaters, with equal grate arous, will surpuss those of this class in the annome of heat they will furnish, or in the economy of their coal consmmption. For cool houses, or when cill'ying about two-thirds of their full radiation, they give very satisfactory results. While their fire surface is rery effectively arranged, it is rather snall for the grite area, and, in cilse the heaters are working up to their full calnaty, in rery cold weather, there will be al cousiderable loss of heat through the smoke flue. Witl these heaters, as with others. it is economy to select one that is a size larger than would be really necessury. For small rrecnhonses the. Neatherod Conical Heater (Fig. 6i) or FI\%. 6S. SPE.TE IIEATER. others of sinilar coustruction will be found quite powerful and eflicient.

In Fig. 6s we present the spence as showing the general form of the horizontul scetional luaters. The fire-pot is surromulud with a water jurchet so that at fire-

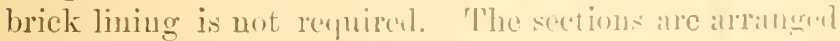
parallel, one above the uther, over the fire-1:at. "T'he construction of the flues is such as brings the proclucts 
of combustion repeatedly in contact with the heating surface, and if this is not snfficient to alsorb all of the leat, the difficulty can be corrected by the addition of more sections. The first, third, and fifth sections are shown in Fig. 69, and the second and fourth in Fig 70 . 'The water is spread out in a thin sheet in the sections and camnot enter the feed pipes mutil it has made a complete circuit of one section. By the arrangement of the water column in the,rear, the water haring passed through one section, is preventer from entering another. The points claimed for this heater are, economy of fuel, perfoct and ripicl circulation, readiness of cleaning, few and tight joints, and, in case of leakige or breaks, the readi-

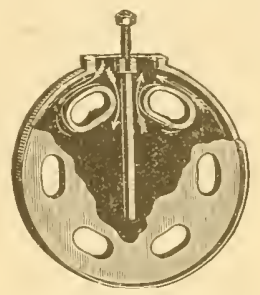

FIG. 69, SPENCE HEATER. (1st, 3el and 5th Sections.)

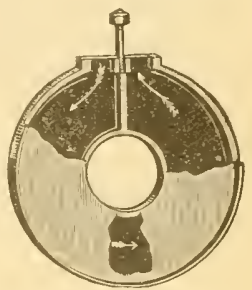

FIG. \%O. SPENCE HEATER. (?d and 4th Sections.)

ness with which repairs can be made. The Gurney, (No. 300 Series) and the Palace King have much the sume construction, and are, very likely, fully as efficient.

The Furman heaters may be taken as the type of the drop tule patterms. They are used either for steam or hot water, the small sizes generally being portable (Fig. 71), and the large ones brick-set (Fig. 72). The Furmam hot-water heater is coustructed on principles almost exactly the reverse of those found in the Spence. It is not sectional in the small sizes, and yet, as the parts are screwed together, they cim be taken apart if any of the tubes are broken. The cast-iron screw joints will prob- 
ably never leak. It will be noted that the heating surface consists of oral drop tnbes, with a diaphliagm in tho center, so arrunged that the water passes down on ono side and up the other. As previonsly stated, the rertical circulation, as secured in the Furman, is the correct one, as there is less friction than in lorizontal tubes or sections. It gives a very rapid circulation, which is of importance in taking up the heat and, also, in giring it off in the coils. A happy illustration of the effect of a rapid circulation upon the amonnt of heat taken up by the water, is the wind blowing over a muddy road, the faster it mores, the more water it takes 11 . The faster the water trarels past the fire, the more lieat will it absorb, and the less will pass up the smoke pipe.

In the Furman, the attempt is made to secure the direct action of the fire upon the tubes, by means of lateral draft between them; this also tends to secure perfect combustion to the very edge of the fire-pot.

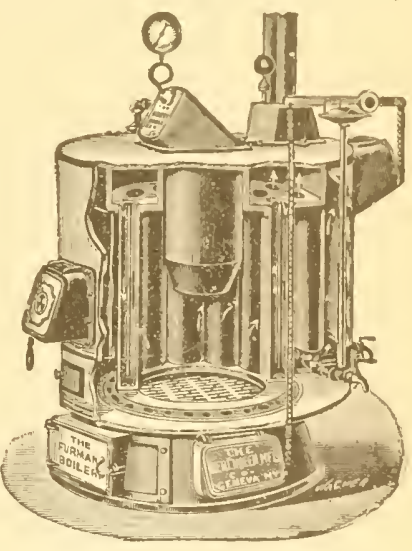

HIG. 71. FURMAN PORTABLE IIEATER (Steam). From their shape and arrangement, rery little cleaning of the flues is necessury.

Althongh constructed upon a general plan exactly opposite that of the Spence, from our trial of the two heaters here, it is not possible to decide which is the correct one; if anything, howerer, the spence is more economical of fuel.

Where the size of the plant will warant, it is better to have two heater's in a battery, than one very linge one, and where two large heater's will do the work on " pinith, 
it is desirable to have a third one to fill back on in serere weather, or in case of an accident to one of the others. If a siugle heater large enongh to do the work in the most serere weather is used, it will be twice as large as will be recnired in the mild weather of Spring and Fall, but, by haring two heater's in a battery, one or both can be need as may be necessitry.

For use in small conservatories, there are many forms of portable hot water heaters, of which that made by Hitehings of C $(0$. , shown in Fig. r.:3, may be taken as a sample. Must of them have coal magazines, and run for eight or len honr's withont attention. From the

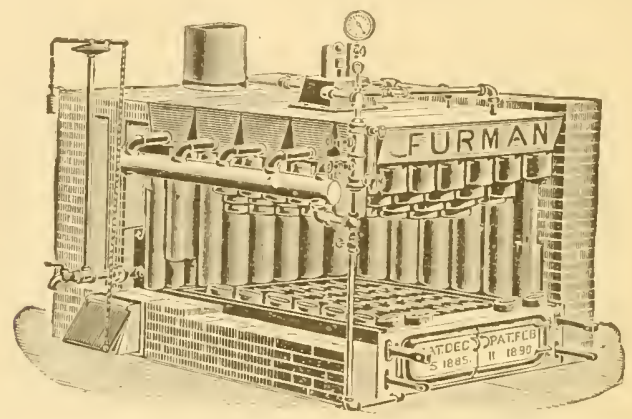

FItr. 72. FURMLAN BRICK-SET HEATER (S'feam).

simplicity of the hot water appratus as first uscel, it will be seen that good results can be obtained from almost any kind of a heater that provides for a proper comnection. A simple cau of copper, zine, or galvanized iron, resting over an oil stove, will provide heat for a small conservatory; but, if some arrangement can be made for increasing the heating surface, better resnlts will be ubtained.

TIIE SIZE OF TIEITER TO USE.

Having determined mpon the kind of heater to use, the size to obtain is of considerable importance. All 
greenhouse heaters are rated by the mannfacturers as equal to smplying a certain mumber of sprutre feet of radiation. Although most of them will do what is elaimed for them at a pinch, it will be at the expense of an exeessive amount of fuel and labor". 'T'he most economical results with hot water can only be obtained will a thin, slow fire in a large fire box, and as a rule it will be well to deduet at least twenty-five per cent. from the manufacturers' rating in estimating the eapacity of a heater.

The comparatice area of grate and fire surface in heaters raries with their arrangement to such an extent that, provided it is ample to absorb the lieat prodnced by the combustion, the latter may be left out of the question for the present. Basing the required grate area upon the number of square feet of radiating surface, it has been stated that for economy the ratio of one to two hundred should unt fIG. 3 . HITCHIxGS BASE be exeeeded. With large

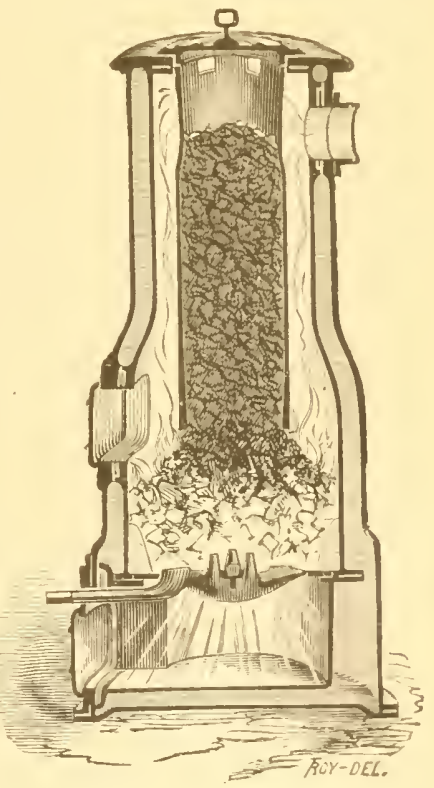

BUIAIYG HEATER。 heater's this should sulfice, provided the radiation itself was ample, lut in small establishments, with less than one thonsand feet of radiating surface, the proportion of one srumare foot of grate surfare to ome lumelred and fifty square feet of ladiating surface will he none too much for" the economical consumption of fucl. In establishments where cheap fucl is used and a night tiremau cwployed, 
one square foot of grate surface will burn enough fuel, with a good draft, to supply two hundred and fifty square feet of radiation.

Of conrse, the ratio of radiating and glass surface must be based, in addition to the temperature to be maintained, upon the elimate, the exposure, the construction of the liouse, ete., but, as a rule, the average temperature in a greenhonse may be taken as fifty degrees, and one foot of radiating surface will heat about four square feet of glass. For an establishment then of 2,400 square feet of glass, 600 square feet of radiating surface will be necessary, and a heater with a grate containing four square feet will be required. If it contains 8,000 square feet of glass, 2,000 square feet of radiation and ten square feet of grate surface will be necessary, and for 16,000 square feet of glass the radiation aud grate surfaces will be respectively 4,000 and sixteen square feet. In the first two cases the fires can be left at night without attention for eight hours in zero weather, but would require stoking once in three or four hours when the grate surface is as small as given in the last example. 


\section{CHAPTER YIX.}

\section{STELI HEATING.}

With the wonderful growth of commercial floril establishments during the past ton rears, a need arose for something more efficient and applicalble to larrer houses than the old-fashioned flue, or the hot water sy'stem with four-inch pipes, and it was found in the modern steam greenhouse-heating plants. In a general way, the same rules and method of piping would answer here as were given for hot water.

In steam heating we have the choice of two methods, high or low pressure. In the first it is rreferable to use wrought-iron boilers rather than the arerage one of castiron, although some cast-iron tubular boilers are clained by the inventors to withstand higher pressures than those of wrought-iron. This method of heating is partienlarly applicable in large plants with more than 12,000 square feet of glass, where a regular night fireman can be employed. The principal arcuments in its faror are that less radiating surface is required than with low pressure steam or with water, and that stean cam be carried to considerable distances, thus centralizing the boilers, and enabling the most extensive ranges of houre to be heated from one boiler-room. For small plants. the low pressure system, earrying a maximum of five pounds pressure, and generally not over two poundr, is preferable.

STEAM BOILERS AND TIIEIR LOC.ITIOX.

Some of the horizontal tubular hoiler's are gremerally used and give gencral satisfaction. For low pressure 
there are dozens of east-iron boilers; each of which has points that, if we ean believe the inrentors, makes his the best; really, howerer, the difference in their real efficieney is very slight. For small houses the locomotive boiler seems to be a cheap and economical heater. They are also used with suceess for hot water. $\Lambda$ s in the hot water heaters, the refuirements for a good steam boiler are ample grate surface, good draft, and a fire surfuce at right angles to the draft, with the flues so arranged as to absorb the greatest possible amount of heat.

In locating the boiler, pains should be taken to have it low enongh so that the water level will be at least two feet below the lowest heating pipe, but if this is not possible without sinking the boiler in dark, poorly drained pits, steum traps can be used, particularly with high pressure, that will remore the water from the return, and lift it to the water level of the boiler; with low pressure they work more slowly and are less satisfactory.

\section{ARRANGEMENT OF TIIE STEAM PIPES.}

The method given for the arrangement of the hot water pipes can be followed with few changes for steam, whether high or low pressure. 'The main for each house should be carried along under the ridge to the farther end, running on a slight decline, where it should be broken up to supply the eoils. If constructed with manifolds, a manifold valve should be used, or, if in separate lines, all but one pipe on each side shonld be arranged so that it ean be shnt off in mild weather. In making the coils, and in fact all comnections, great eare should be taken to allow for expansion.

For short eoils, one-ineh pipe may be used, but if of considerable length, one and one-fourth inch pipe is preferred by most florists. The slope of the coils shonld be towards the boiler, when the flow is carried orerhead, in 
order to return the contensed water. It the ent of the honse the returns shombl he eollected into one pripe, which shonld cuter the boiler below the water level.

There should be an antomatic air valve on eacle of the coils at the lower end, and on the return, near the boiler, it is well to have both a valve and a check valve.

As recommender for hot water, it is well to have the pipes somewhat distributed, and if, in adlition to the orerhead mains, one return pipe is earried along on the wall plate, it will tend to warm the cold air that enters throngh the rentilators, or eracks in the glass, before it comes in contact witl the plants. With plants like cucumbers and roses, that are susceptible to cold iraftz, this will be found a deciled adramtage.

\section{AMOTXT OF PIPE FOR STEAI.}

The amount of pipe, hoth for mains and coils, will be much less than when hot water is used. For the main it can be reckoned that a

\begin{tabular}{|c|c|c|c|c|c|c|c|}
\hline 2 & " & 4 & " & 400 & ." & $\therefore$ & $\therefore$ \\
\hline $21 / 2$ & " & ". & 6. & 800 & 6 & " & " \\
\hline 3 & " &.$:$ & " & 1.600 & .. & " & " \\
\hline 4 & "6 & " & ". & 3.200 & " & 6 & " \\
\hline
\end{tabular}

The surface of the steam pipes is from thirty to fifty per cent. warmer than that of hot water pipes. and a corresponding decrease of the necessary rathinting surface can be made. For low pressure steam, in aldition to the mains, a house will require for each 1,000 symure feet of glass, to warm it to

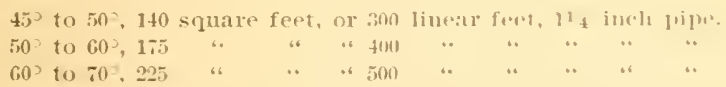

With high pressure, a considerable rednction can be made firom the above.

In figuring the capacity of a hoiler, athont fiftenn feet of lieating (fire) surface should be rectioned an one 
horse power, and in estimating the radiation that it will supply, from fifty to ninety square feet of radiation per horse power, according to the pressure, may be relied upon with a good boiler. If we consider that for a temperatmre of fifty degrees, which may be taken as about an average, one square foot of rarliating surface will take care of six square feet of glass, one horse power will be snfficient for 300 to $5+0$ square feet of glass. As in the case with hot water lieaters, a large steam boiler will handle more glass to a square foot of grate than a small one.

'The size of grate for a given glass area will also depend upon the draft of the ehimner, the skill of the fireman and the method of stoking used. With a poor draft a much smaller amount of coal can be burned, per square foot of grate, than when the draft is strong, and a grate area considerably larger than in the latter case will be required ; the sime is true of a dirty fire as compared with a clean one. For establishments with less than 10,000 to 12,000 square feet of glass, a night firemin can hardly be afforded, and a large grate should be nsed upon which a slow fire can be burned that will last from six to ten homrs. For this purpose the grate should have an area of from fifteen to eighteen or even twenty feet, aceoring to the climate and other modifying conditions. On the other hand, when a strong draft can be secured, and in large establishments, where a night fireman is employed, one square foot of grate can rearlily handie one thousand square feet of glass. In other words, a steam boiler with twolve square feet of grate can be marle to heat with economy 12,000 square feet of glass. Under farorable conditions, eight square feet of grate will heat a house containing the above amount of glass to fifty degrees.

The matter is so important that it is well to again mention the advisability of putting in a boiler with a 
capacity twenty-fire per cent. lingere than is reymired to do the work, and of arranging for ample rachiating surface.

The only other matter of real importance in atranging a system is to have the pigres with sulde a fall (1me inch in twenty feet will answere) that the water of condensation can readily drain ofl. 'This can hest los secured, if there is a gralnal desecnt in the pipes from

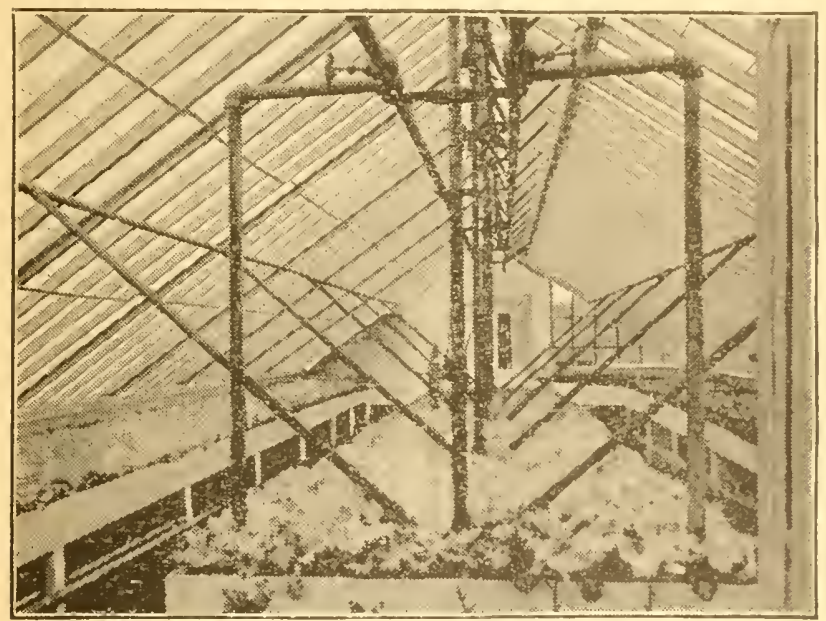

FIG. 74. INTERIOR OF STEIM-HE.TTEI HOLSE.

the point where the main enters the homse to where the return leaves. If it becomes nevesily to changere the direction of the slope, a one-inch hrip pipe shomld be comnected with the undersile of the main, at the proint where the direction of the pipe ahanges, amel joined to the returns.

A TOTHER METHOD UF I'HIXT'.

Although the orerliear main will generally give best satisfaetion, particularly in long loneses, it is sometimes 
preferred to have them all under the bench. The coil can commence at the end of the house nearest the boiler, and with a gradual fall to the other end, from which point the return can descend to the heater. 'These coils can be underneath the side benches or in the walk, and, if desired, in wide honses under the center bench, also. This method of distributing the pipes will be particularly desirable when the plants are placed ont on the benches.

In short houses the coils can rmu entirely around the house, although the short runs will be preferable. With low pressure it is not adrisable to lare coils more than two hundred feet in length. Even for houses of this length, it will be very convenient to have the different honses in the range comnected in the center by a cross gallery, in which the boilers may be placed, and through which the mains and returns can he rmn and connected with coils which will be half as long as the house. Fig. it shows one method of piping a small liouse for steam, the furnace-room being at the farther end of the house.

Various methods of arranging steam pipes are shown in Figs. 58-6?. As a rule, a two-inch steam main can be used instead of a three-inch hot water main, and a one-inch steam pipe will be equivalent to an inch and one-half hot water pipe in the coils for low pressure, and a two-inch pipe if the steam is under high pressure. 


\section{CHAP'TER TX.}

COMPARATIVE MELITS OF STEAM ANU HO' W.ITER.

The following are among the clatims marle by alrucates of steam for their farorite heating system: (1) A lower first cost: (:) ability to maintain a strady temperature; (3) realiness with which the temperature call be raised or lowered if tesireil: (t) economy of coal consumption; (5) ease with which repalirs can be matio.

The hot water men almit that these elaims holil to a large extent against hot water in fonr-inch pipes. lut they contend that the mon who make these claims have made no comparison with modern well-arrangerl hot water plants, and that, uncler proper conditions. the litter system is preferable. 'l'hose who firvol hot witur claim for that methed that at the most only the first claim of the stcam men will stand, and that on the other points, hot water can malie as gooul, if not better showing.

With regarel to the first enst, as stated before, the amount of radiation repuired for hot water with an open tank is about forty per cent. more than with steum. which will make the cost of the plant albont twenty per cent. more than the cost of a steam plant. Under pressure, however, the cost will be little if any more. lnit we shall lose in economy of fnel, as eompared with the open tank system, although it retains all of the other alvantages clamed for hot water. With a fireman giving constant attention to the boilers, a steirly presille cam be maintained, and of ennrse the pipes heing all of the time at the same temperature, there need be but littlo 
rariation in the honse, provided the pressure is raised or lowered, or the valres are used to regulate the amount of radiation, according to the ontside temperature.

In small plants, where regular firemen are not employed both for night and day, the pressure will vary to a greater or less extent. In well-arranged plants, boilers can be left in severe weather for six or eight hours, and pressure will be maintained, provided everything is all right: but if for any reason the water in the boiler drops below $212^{\circ}$, the steam pipes will cool, and serious harm may result. With hot water, circulation will go on so long as there is fire in the heater, and the water in the pipes will gire off heat eren after that, until they cool to the temperature of the house. It can then be claimed for hot water, and no one can deny it, that in small plants, hot water is safer than steam to use, and can be left for a longer time withont attention.

It is also urged in faror of steam, that in long rums the hot water becomes cooled, and that the temperature at the lower end of the coils will be less than at the other. In a short honse of one hundred and fifty feet or less, this can be comnteracted by using the overhead main and underbench returns, and even in long honses the difference, with this method of piping, shonld not exceed fire degrees in a house two hundred feet long. If the continuous coils of one and one-half or two-inch pipe rumning through the house and back are used, which may be done where a fall of one inch in ten feet can be secured, there may be even less difference than is fonnd in steam pipes.

There is, then, some ground for the claim of hot water men that, eren compared with large plants in which night firemen are employed, the temperature at the opposite ends of the houses will be as even as with steam, and that the hot wuter system properly arranged will maintain for eight or ten hours a temperature as even as will be secured from steam by the average fireman. 
The claim that stean eam be werl to better antrintage when it is desirest to latise or lowee the tempremature of the house, only applient against watere in liuger pijus. If desired, the entire cireulation in the hot water (wils can be shut off, and the ammont of heat in the water in the pipes if given off at once would mot raise the temperature of the house a single degree, and nistributed orer an hour or so, would not be noticed. With fonr-inch pipes eontaining ten times the guluntity of water, aml, especially as valyes were not always provided for shutting off the cireulation, the heat given off was suflicient to necessitate the early opening of the rentilators on bright mornings and a corresponding injury from cold drafts upon the plants wals eaused. With small pipes, starting with cold water or with a moderately low fire, a normal temperature of the pipes can be sucured is quickly as with steam. When the question of economy of fuel is considered, the general opinion of those who have earefully tested steam against the morlern liot water system, is that the latter is abont twenty-tive per cent. cheaper.

\section{EXPERIMENTAL TESTS.}

There are on recort a large number of so-called tests of the economy of steam and hot water, but in nearly every ease the hot water was in four-inch pipes. The only experimental tests that have come to the notice of the writer, where the houses and plants were of similar construction, and the tests were carried on at the same time, Was the one by P'rof. Marynard, at the Massachusetts Experiment Station at Amherst, and those of the anthor at the Nichigan Experiment Station. In each case piping was arranged in both honses with orerhead mains and underbench coils, amel although an attempt was made to have each plant at perfect as possible, the conditions for either system were no more firor- 
able than conld be secured in any forcing honse. The homses at Imherst were sereutr-tire by pighteen feet. and those at Lilnsing twonty by tifts feet each.

The tests were continued in eash place for two years with the following results:

\begin{tabular}{|c|c|c|c|c|}
\hline & \multicolumn{2}{|c|}{ AVERARE TEMPERATTRE. } & \multicolumn{2}{|c|}{ CDAL COSSEMED. } \\
\hline & Water Ilouse. & Steam Houss. & Water House. & Steam House. \\
\hline $\begin{array}{l}\text { Amlierst. } \\
\text { Libl sing. } \\
\text { trerige. }\end{array}$ & 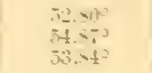 & $\begin{array}{l}511,010 \\
53.0= \\
51.21\end{array}$ & $\begin{array}{l}\text { lis } .54 \text { lbs. } \\
14 \ldots 3 \\
\text { s.2.14 }\end{array}$ & $\begin{array}{l}91.4 \mathrm{lbs} \\
114.23 \% \\
113.01 \quad *\end{array}$ \\
\hline
\end{tabular}

Or almost exactly twenty-tire per cent. more fuel was required for steam than with water. althowgh the steam houses areragel about two degrees cooler.

In both places the hot water honse wis more exposed to the cold winds than the steam house. and. at Lansing. where the results were less favorable for water than at Anherst. although the houses were piped for maintaining a temperature of forty-fire to fifty degrees. they were kept at a temperature of tiftr-fire degrees. necessitating a considerably higher temperature of the water than shomld have been carried for the greatest economy of fuel. Which rould make less difference with the steam system. In proof of this. additional pipes hare now been pnt in, and the hot water honse is now carried at sisty degrees with no more fuel than was used at fift -fire legrees.

COIPPARATITE COST OF FTEL.

Tith steam it is claimed that a cheapel grade of fuel can be used than with hot water. but boilers for hot witer are now made that can secure better results from soft coal than is obtained br steam. provided similar care is giren. It is also claimed for steam that it admits of the boilers being located in a battery at one point. rather than scattered in different houses as is generally the case with hot water. With modern srstems of piping, the 


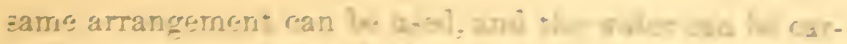

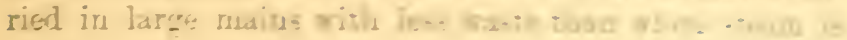
userd.

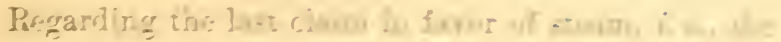

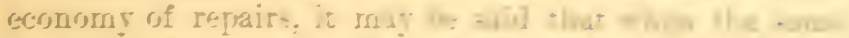

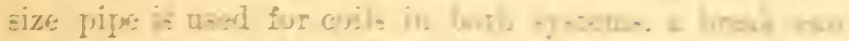

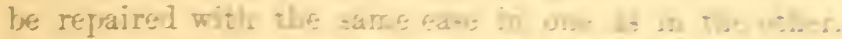

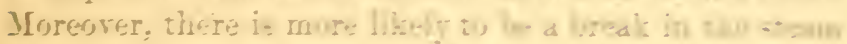

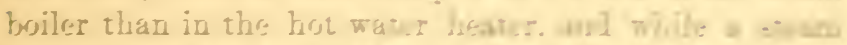

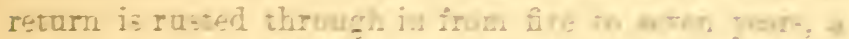

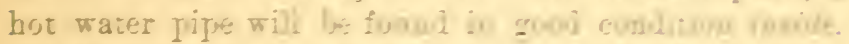

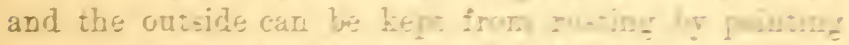

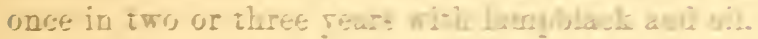

$$
\text { CNTCET:IN, IN }
$$

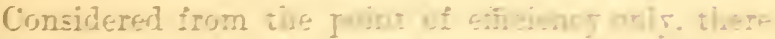

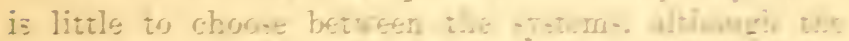

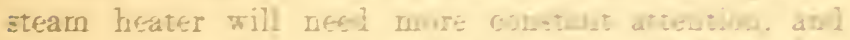

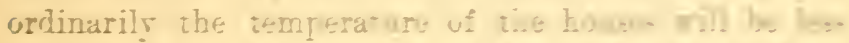

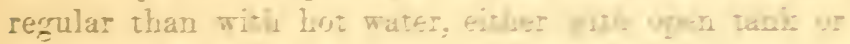
under pressure.

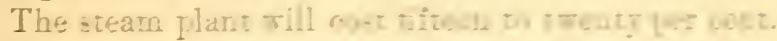

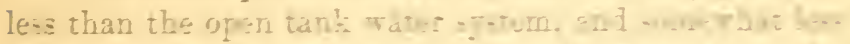

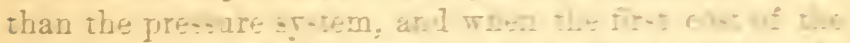

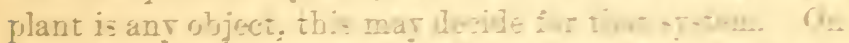

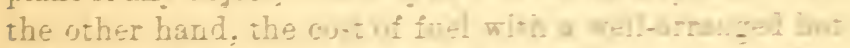

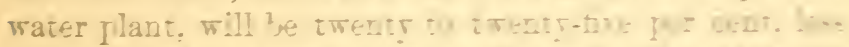

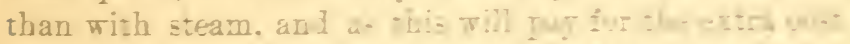

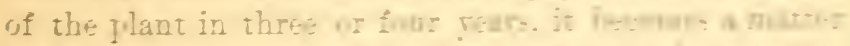

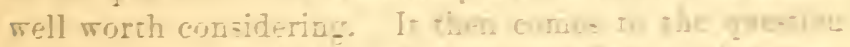

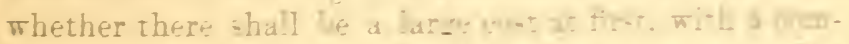

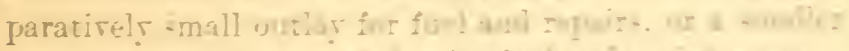

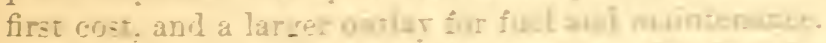

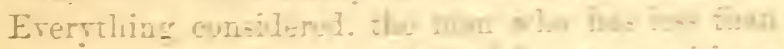

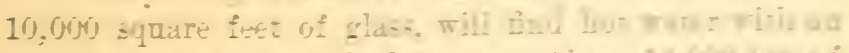

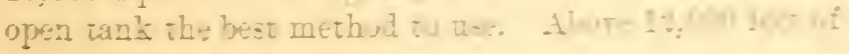


glass, it will pay to hare a night fireman, and, as the first cost for a plant of this size is considerable, the average florist will prefer to use steam, although hot water will give fully als good results, and the extra ex. pense of the plant will be saved in fuel within four years. So far as cxpense for fuel is concerned, hot water under pressure will be classed with steam; it gives more even results, howerer, and the eost of the system is little if any more. In arriving at these conclusions, no account is taken of the effect of the different systems upon plant growth, as we believe that when equally well cared for there will be little or no differenee.

\section{CHAP'TER XXI.}

\section{HEATING SMALL CONSERVATORIES.}

For amateur conservatories, with orer 300 square feet of glass, unless joined to a residence which is leated by hot water or steam, it will be found desirable to use some of the small portable hot water heaters that are manufactured by several firms. When these are used in connection with a well arranged system of piping, the care of the house is greatly simplified, and there will be little risk of injury to the plants by cold. It will be a desirable thing, if the dwelling is heated with stuves or a hot air furnace, to purchase a heater large enough to warm a part or all of the house, and put in pipes and radiators.

In arranging the heating system for the conservatory, the heater shonld be placed in the cellar of the house, and the feed pipes should pass up through the floor and connect with the radiating pipes, which are gemerally best if arranged in a wall coil, with mauifolds 
at each end. An air valve will be neenterl at the higher end, and an expansion tamk shonld be connectert with some part of the system. It should be of gulvinized iron, although an old paint keg would answer. It shontil hold a gallon for each hundred feet of one and one-fourth inch pipe, and a gallon for the heater and mains. If the tank is situated where liam to floor or walls will be done if it boils orer, it is well to have a tight corer on the tank and run an overflow pipe from half-way up the side of the tank to a drain.

For conservatories which are too large to leat with an oil store, a home-male water heater might be used. The radiating coil and attachments would be similar to those just described. A small heater could be made by using a small coil of one-inch pipe containing eight linear feet of heating surface, inside one of the large sized kerosene heating stores. This would wan one hundred and fifty linear feet of one-inch pipe, and would heat a conservatory six by ten feet with three sides sul roof of glass. Were the conservatory npoul at reraulil where only the roof, side and one end were exposed, the capacity would be sufficient to rarm about six by fifteen feet, and if the roof were of wood, it conld leat a space eight by twenty feet.

\section{THE BATAARD IIEATER.}

In 1890 Charles Barnard described in the Amrricen Garden a very simple heater that gave good satisfiction in a detached greenhouse. 'The heater wis of zinc: with four tubes of one-inch gas pipe (Fig. 75 .1); the diameter was six inches and the height twenty-seven inche'. From this, connections were male with the coils which were of two-inch pipe, although one and one-ginirter. inch pipe would be preferable. The heater wis plicerl over an oil stove or gas burner, and was surrounled ly it jacket of sheet iron (Fig. $15 \mathrm{~L}$ ) from which a small 1 1ipe 
ran to the ontside of the house to convey the smoke and gases. Another form of heater is made in the shape of a hollow truncated cone, nine inches in diameter at the bottom and six at the top, and twenty-four inches high. 'The water' is one inch in thickness and is confined between the inner and outer shells of the heater. This is placed over an oil stove and arranged in much the sime way as the one last described.

\section{HEATING BY MEANS OF FLUES.}

In small houses where one does not liave the means to put in hot water or steam, fairly good results can be

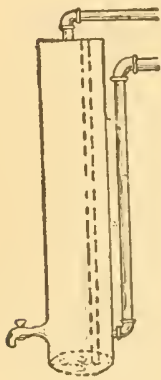

$A$

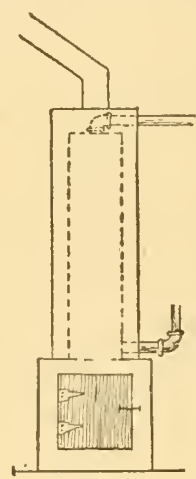

$B$ obtained with the old-fashioned flue. This consists of a furnace in which the fuel is burned, and a horizontal chimney passing through the house. If the house is not over fifty fect in length, and if a rise of two or more feet can be secured, a fair draft can be obtained by having the chimney at the farther end; but in longer houses, or where the flues must be run on a level, it is best to bring them back, FIG. $\% 5$. so that they can enter a chimBARNARD HEATER. ney built over the furnace.

A direct connection with the chimney can be made when the fire is first started, and then, after the chimney has become warm, a damper can be turned which will force the smoke to pass around through the louse, giving off its heat as it goes. The furnace can be constrncted for burning either coal, or wood cut in lengths of from three to five feet. A grate containing three to four square feet will answer for a house containing 600 square 
feet of glass. If wood is msed, the fnmace should be eighteen inches wide inside, and of the leypired lengtl, but no increase of the size of the grate will be necessary. There should be an ash pit of suitable size, and iron doors should be set in the masonry at the end of the furnate, for both the fire-pot and ash pit. The top of the furnace may be supported either by a brick areh or by heary iron balrs. 'The inner lining of the heater' shonld be of fire brick laid in fire clily, and the same material should be used for the first fifteen feet of the flue. Beyond this point, common stock brick will answer, forming a flue eight by twelve to sixtecn inches, or eight to ten-inch glazed tile may be used.

For a house twelve feet in width, one flue will answer; but if fifteen to twenty feet wide, it is well either to have a return flue on the other side, or to divide the flue and carry up a branch on each side, either under the walks or beneath the side benches.

A hot water coil ean be economically combined with a fluc by using cross-pieces of one and one-half inch pipe, comnected by return bends, across the side walls and. supporting the top of the heater, and connecting them with the radiating pipes. If a flue is nsed eare should be taken that no woodwork comes in contuct with the bricks within thirty feet of the furnatee. When houses are very long, furmaces may be placed at both ends and the flues can be carried lialf the length of the house and bronght back on the opposite side.

\section{THE POLMAISE SYSTEM.}

The Polmaise system wils so-ealled from the French town where it wals first used. The original system consisted in bringing a current of air orer a heated surface, and then carrying it intu the greenhonse, on its way passing through a wet blanket, that its drying effect might be lessened. The system itself is of no value, but 
a modified form of it may be used in connection with a flne. By building an air chamber around the furnace and admitting the air, much as in common hot air furnaces, it will be warmed, and can be earried through the house in tiles much as are the products of combustion.

The cost of a flue is less than half that of a hot water or steam plant, and especially if combined with hot water, as described, very satisfactory results can be obtained. The modified Polmaise system could also be employed with profit, if the coil is not used.

\section{FIPE HOTBEDS.}

In addition to warming hotbeds by means of decomposing manure, varions other methods of heating have been tried, the simplest being a modified form of the ordinary flue as just described. The beds can be single, for sash six feet long, or can be double span-roofed structures, with a row of sash on each side. For the single beds the arch or furnace neel not be over one foot wide inside, eighteen inches high, and four or five feet long. It should be arched over with brick and the whole then corered with soil. In order to secure proper slope for the flues, the hotbeds should be located on a hillside sloping to the south, and the fines should have a slope of about one foot in twenty, althongh more is desirable. The tile used for the flues should be giazed for the first twenty fect at least, and six inches in diameter, and should be laid in two lines, three feet apart; at the farther end the tile should be turned up at right-angles forming a chimney: An ordinary hotbed frame should be set over this. The soil at the furnace end shonld then be spread on, corering the arch to the depth of twelve to fiftecn inches, and the pipes at the chimney end about six inches. The draft can be regulated by a plate of iron resting against the end of the arch. The structure will last several years, and will prove a great 
convenience where one does not have at gremhouse in which to start regetable plints, and where wool is chealy.

For the span-roof hotbed, two arches of furnaces and four flues, arranged as in the other casc, will bx required.

STEAI ATI HOT WATER HEAT FOR HOTHEHS.

If it is desired to warm hotbeds by means of steam, it cam be done by running a one and one-ritarter incls steam pipe up in one line of four-iuch dlain tile, and back in another line laid as described for the flues with the narrow beds, while four lines wonld be required for a bed twelve feet wide. When exhaust steam is at hambl it ean be nsed withont the steam pipe by merely discharging it into the tile.

A frame ean be heated by lrot water or steam if a two-inch hot water or an inch and a quarter steam pipe is: rum around the inside, next to the plank. Boards shoulıl then be placed so as to shut ofi all direct heat from the plants. If a crack two inehes wide is lefic between the top of the boards and the glass, the heat will be diffused and will not dry out the plants.

\section{CHAPTER YYII.}

COMMERCIAL ESTABLISHMENTS.

A florist just starting in insiness mily lo compelled by lack of means to commence nuon a small scale. While he would find a lean-to lrouse the eheapest to erect-provided he built it against the south wall of a building - the excess of cost for a spin-roof house would be so slight, and the results obtained wonld be so much greater, that he would be wise in selecting that form for a house. The size for the house must be determined by 
the business to be done, but for most purposes a house of twenty feet in width is preferable to anything narrower, and an enterprising florist shorld be able to utilize one that is fifty feet long. It is desirable to have both

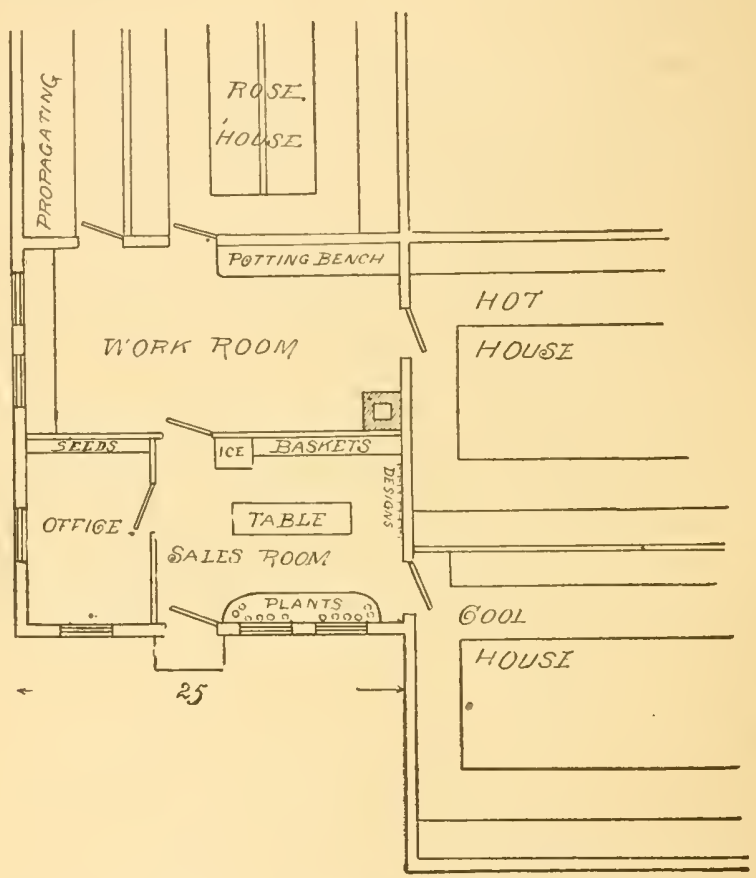

FIG. 76. PLAN FOR A SMALL ESTABLISHMENT.

a cool and a warm house, and this cau be secured by running a glass partition across the house.

If this amount of glass is not sufficient, a second house can be built similar to the first one, and then he will have one house to be kept at a temperature of fiftyfive to sixty degrees and another that can be kept at forty-five to fifty degrees. Although other houses are 
desirable, a good selection of plants can he grown in two such honses with fair success. If business fexcloper, ats it should, it will be clesirable to add a lone house. This shonld be of the three-quarter span form, eightem ans? one-half feet wide, and will give an opportmity for the erection of a north side propagating house, which can not only be used for propagating, hut will be excellent for ferns, violets, pansies, and for the starting of seeds ant bulbs. The even span houses conld rmu north and south with a workroom at the north end twenty-five by twentyfive feet, while the rose honse conld join the end of the workroom and run east and west, as shown in Fig. if. A convenient arrangement for the workroum and store is shown in the illustration, which can readily be understood.

If still other enlargement of the estahlishment becomes necessary, the additional buildings can be put up parallel to the present ones, or they can be run ont the other way from the workiroom. Another method would be by lengthening the buildings already put up, but for small establishments it will hardly be desirable to extend them beyond a length of one hundred and fifty fect.

In addition to the general florist and regetable grower, we find to-day engaged in greenhonse work many specialists, and among these the commercial rose grower and the lettuce grower, from the extent of their business, are especially worthy of notice. As in crerything else, we find, as a rule, that these specialists who have turned their every effort to the doing of one thing well, are masters of their business. and have been quick to avail themselves of all the latest inprovements. 


\section{CHAPTER XXIII.}

\section{ROSE HOUSES.}

The form and general arrangement of the houses used for forcing roses, is practically the same the country over, and when one speaks of a "rose house," he is - readily understood. A rose house may be briefly defined as a three-quarter span greenhouse, abont eighteen feet wide, with two narrow beds at the sides, and with two somewhat wider ones in the center. No form of house has been tried for this purpose that is on the whole as satisfactory as this, of which a good example of an $c x-$ terior will be found in Fig. $7 \%$

They are cheapest to build and easiest to heat if constructed with wooden walls up to the plate, as shown in Fig. 82, but mauy of onr best rose growers are of the opinion that the extra cost of erection and maintenance is more than repaid by the results obtained, when there is from eighteen to twenty-four inches of glass in the sonth wall and ends under the plate. There seems to be a dirersity of opinion as to the best width for rose houses, the range being from sixteen to twenty feet; but it is the general idea that in the honses sixteen feet wide there is a lack of economy of space, mnless the walks are made rather nilrow. With the side walks eighteen to twenty inches wide, and a walk between the center benches with a width of twelve inches, there will be room for four benches of arerage widths; but for convenience the walks at the side should not be less than two feet in width, and the center walk from fifteen to eighteen inches. A convenient width for the front bench is thirty inches, which 
will answer for three rows of plants; the center herls should be three feet and six inches, each holding four rows, and the back bed two feet in width with two rows of plants. If the front wall is made six inches, and the rear one eight inches in thiekness, with the bunches set out to prevent drip from the plate, a honse with the above widths for walks and benches will he alunt eighteen feet and six inches to the ontside of the walls. In locating the height of the benches, the tops of the eross bearers for the frout and back bench should be about twenty inches below the plates; the sontl center" bench should be at the same lieight as the front hench, and the north one abont eighteen inches higher. Some growers prefer to have hoth of the center benches level, but if careful attention is given to the watering, rather better results will be obtained if they are giron a slight slope to the sonth, say of eight inches in the width of one bench or of eighteen inches between the walks (Fig. 63).

It is quite desirable in arranging the roof to loave the ridge and purlin come over the walks. If an iron frame-work is used with a truss at the ridge, there will be no necessity for a support mnder the ridge; Jut if the roof is of wood, particularly if there are no principal rafters, a post should be used, and the ridge should he so located that the post ean pass down at the north side of the center bench. While one purlin with one row of posts-in addition to the one under the ridge-will sulport a roof of this wilth, lighter material cin lie employed, and there will be less tromble from drip) if two of each are used, with the josts coming (lown at the south side of each of the center hemelies.

Particularly in rose forcing lomses, it is clesirable to have the slope of the rouf armangerl to tralp als much ats possible of light and hat from the sun during the winter months, and, ererything else consicleren, the south 


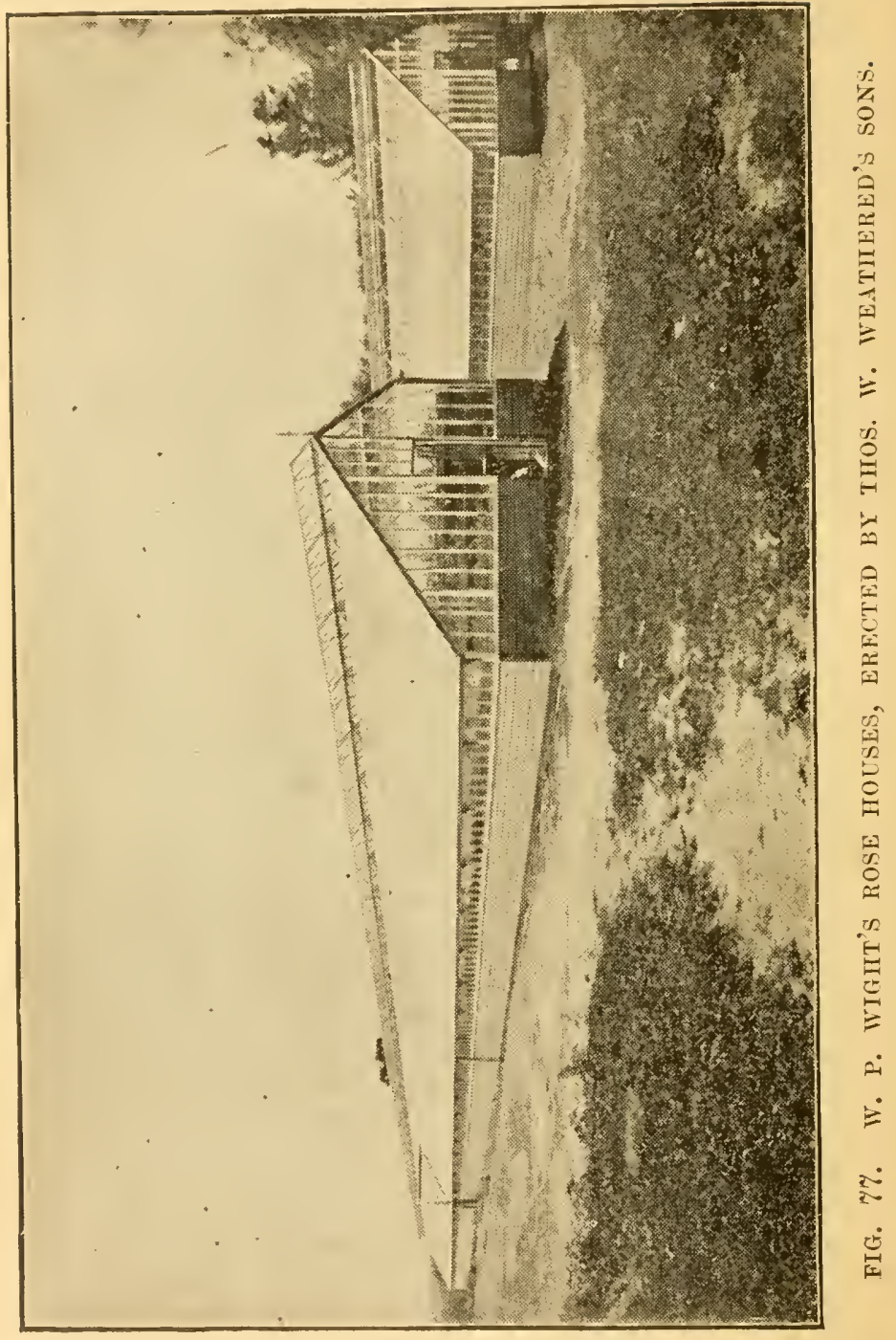




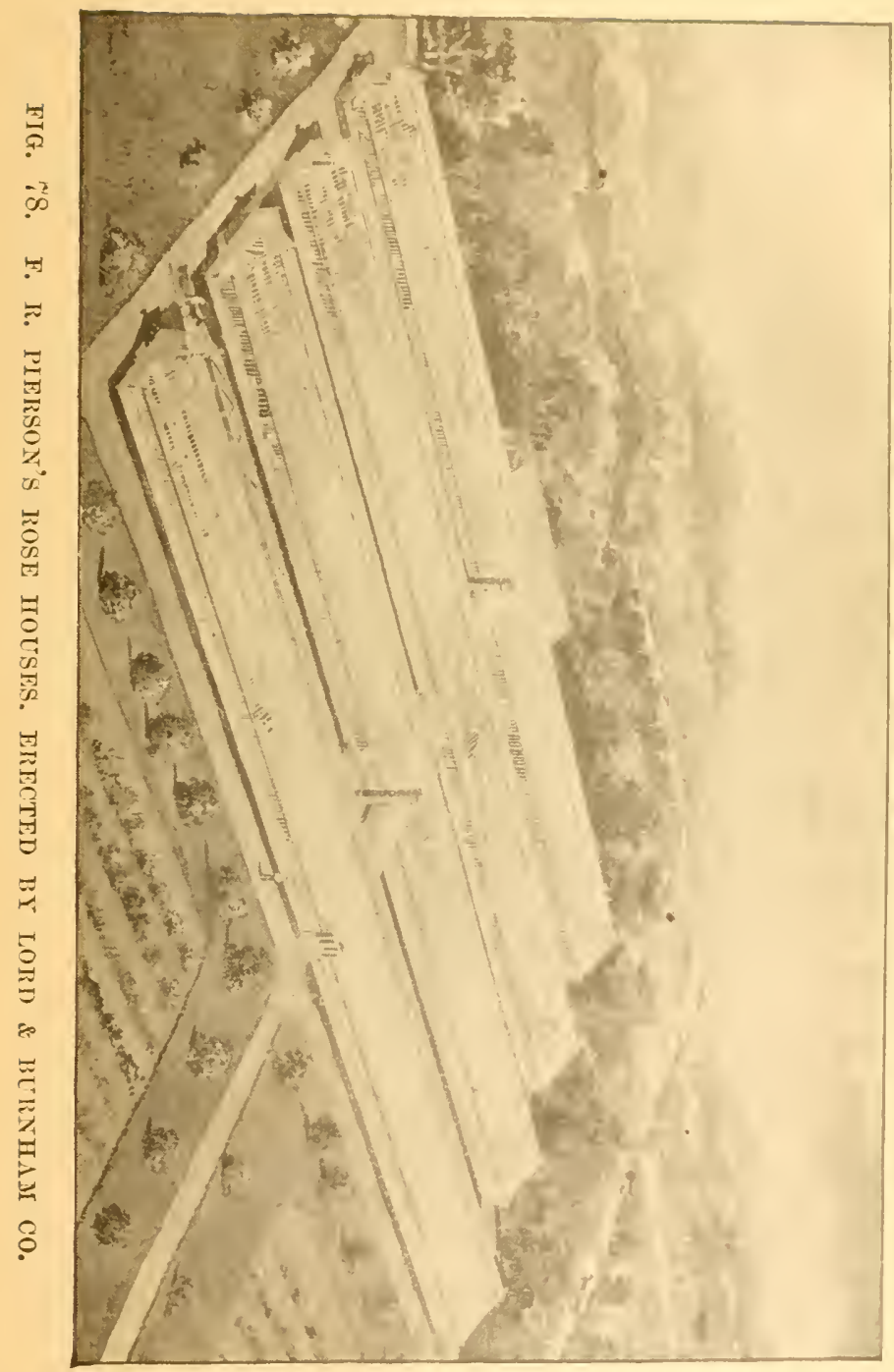


pitch of the roof should slope at the rate of about two feet for erery three feet in width of honse. With the ridge posts at a distance of fourteen feet from the ontside of the sonth wall, the bottom of the ridge shonld be abont eight feet higher than the top of the sonth wall, or twelve feet from the ground level, with the sonth wall four feet in height. 'This will require a rafter slightly less than sixteen feet in length on the front, and six feet on the rear slope of the roof, when the rear wall is eight feet in height. Another good form for a commercial rose house is the one described in Chapter III., with the sides of the roof fifteen and seven and one-half feet, and the height of the front and back walls five and seven feet respectively. In a house of this shape there shonld be a line of glass under the plate of the sonth wa!l (Fig. $\%$. $)$. While the even-span house is not as well adapted for rose forcing as the three-quarter span honse, it is frequently used, and will gire very fair results. These houses may be eighteen to twenty feet wide, with four benches, about three and one-half feet each, in width.

The best resnlts seem to be obtained from benehes not over four inches in depth, although this varies with the character of the soil, as three and one-half inches of heavy soil will be equal to fonr and one-half inches of soil of a sandy nature. In seleeting the material for the bottoms of rose benches, a first choice would be for tile, second slate, and third wood. In planning our rose houses everything has been arranged npon the presumption that shallow beds were to be nsed, as this seems to be the favorite methor of growing them.

When there is no glass beneath the plate on the sonth wall, the custom in the past las been to have a single line of ventilator's at the ridge, but many of the more recently eonstructed houses have a line of sash on each side of the ridge; if these are properly used, the draft of air upon the plants is greatly decreased. The 


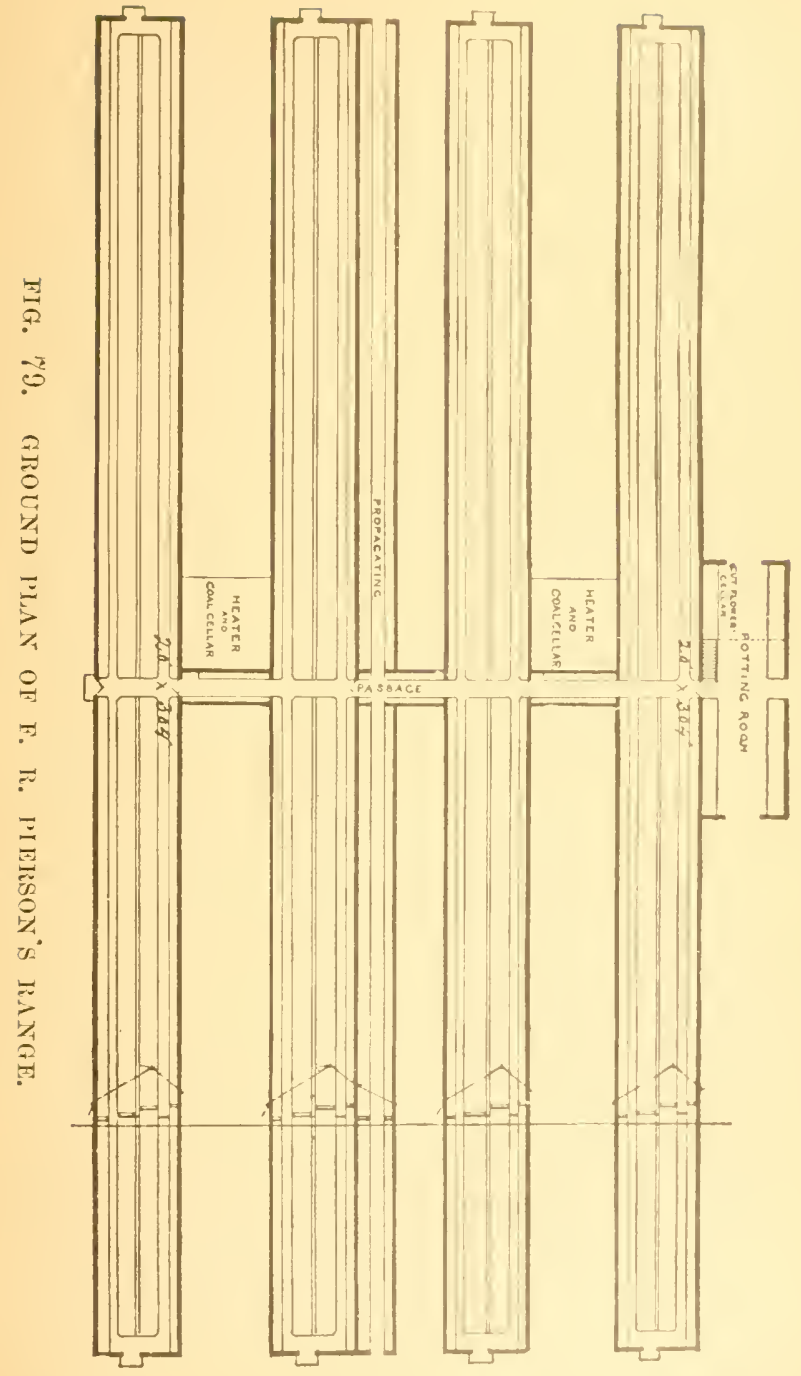


nse of rentilating sash in the sonth wall is also quite common.

During the last five year's many large and well arranged commercial rose houses have been erected, and we are glad to be able to show illustrations of two plants that contain many of the latest ideas. In Fig. ry will be scen a prerspective view of the rose honses erected for Wr. I'. Wight of Madison, N J., by 'Thos. W. Weath-

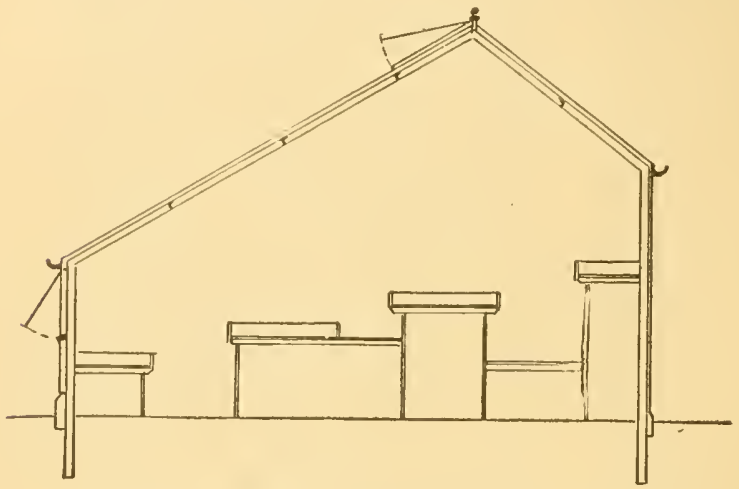

FIC. SO. SECTION OF IRON ROSE TOLSE.

ered's Sons of New Iork City. From this we ean get an idea of the general appearance of the better class of commercial rose houses. They are each alout three humdred feet long by twenty feet wide.

One of the best arranged and most thoroughly constructed commercial greenhonse plants in the comntry is shown in Fig. \%8. It was built in 1890 at Scarborough, N. Y., for F. R. Pierson, by Lord \& Burnham Co. As will be seen by the ground plan, Fig. 79, there are eight honses, each measuring one hundred and fifty by twenty feet. They are placed in pairs, end to end, except for a narrow passage way which affords a ready means of communieation with the different houses and with the

$$
\text { ' BOOPFRTY OF }
$$


potting sherl. At the rear of the seconnt line of houses is a propagating house, nine fuet wide and threw humblew feet long, or really two houses cach one humilerl and fifty feet. 'The construetion is the same as is recommended in Chapter VII., the rafters and posts being of iron, with the lower ends of the latter set in "'ment in the ground. The purlins and ridge are also of iron and all woodwork of cypress. The henches have an iron frame and slate bottom. 'I'he heat is fnrnisherl fiom steam boilers located as shown in the gromul plan. I cross section of one of these honses is shown in Fig. so, from which one can obtain a good illea of the slope of the roof and of the interior armement, while Fig. 81 shows another method of construction.

A house of this description can be erected for alont $\$ 25.50$ per running foot, including the stemm-heating apparatus. With hemlock benches the cost would not be orer $\$ 20 . \% 5$, and were the glass left ont muler the south plate, leaving only one line of rentilating appraratus at the ridge, the cost could be rednced to $8 ? 0.00$ 1er linear foot. This would gire double strength, French "seconds" or American "firsts" glitss, and two coats of paint. Reckoning the steam-heating apparatus at $\$ 4.50$ per linear foot, the honse complete ats ithore, with cheap wooden benches and without heating apparatus, would cost something over $\$ 15.00$ per foot. When iron benches with wooden bottoms are nsed, the house with one row of ventilating apparatus and steam-hating ipparatus, wonld cost not far from $\$ 2: .00$ per foot. If onc does nut care to use the iron construction. cypress lumber can be obtained for the erection of at rose, or, in fact, of any kind of a greenhonse, all gotten out in the mo:t alpproved sizes and shapes, reanly to be fitfed togethere.

There are a half-dozen or more firms who mike at specialty of cypress for greenhouse building, amung the oldest of which is the Lockland Lumber Co., of Luck- 


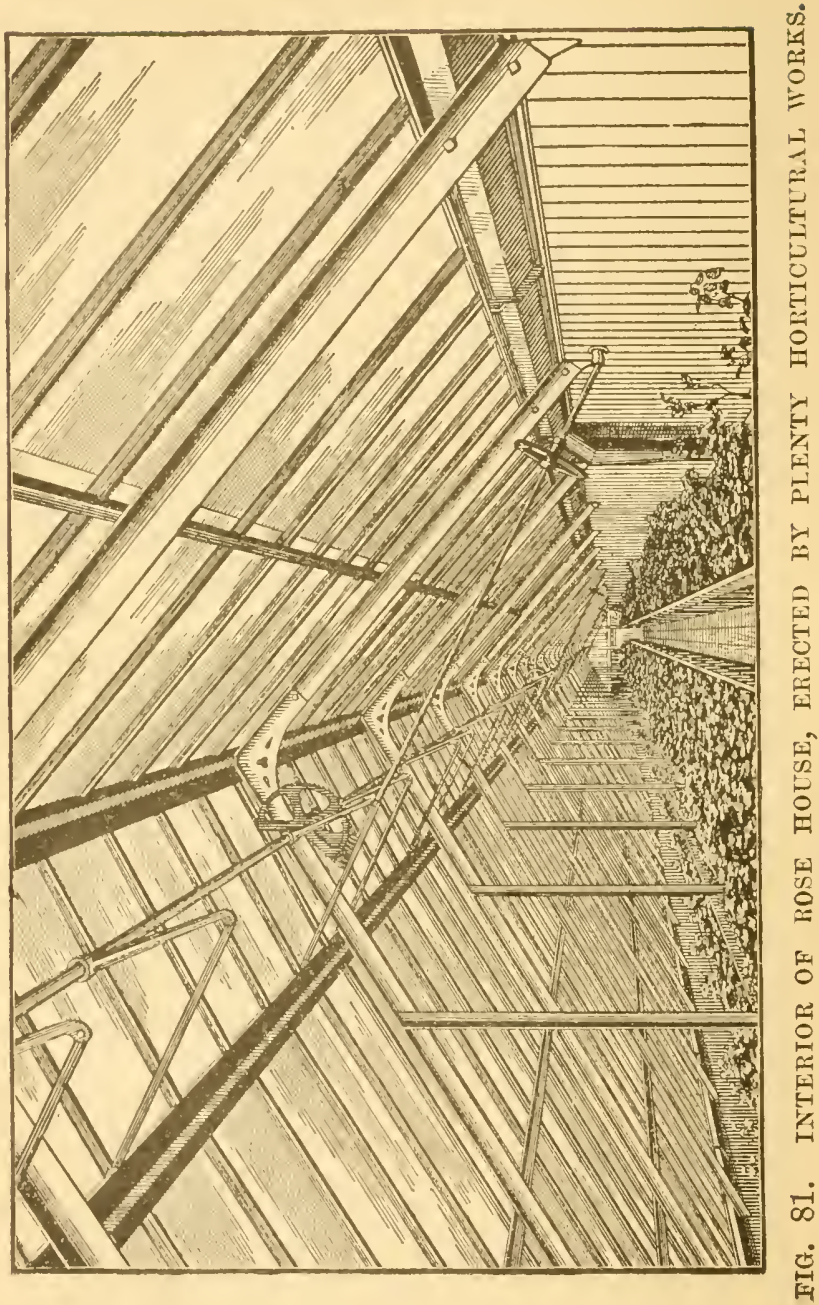


land, Ohio. By request they have prepured a gromud plan, cross section and details of a rose house such as they furnish, and they are here presented as sueren-tions to prospective builders. The eross section is stumn in Fig. S2 and is so clear that any carpenter conld jut the house together. The details are shown in chapter. II. and afford ns an idea of some of the best shanes for the different parts of a greenhonse, and the way to jut them together. The patterns do not differ materially from those used by other tealer's in greenhouse materials, and

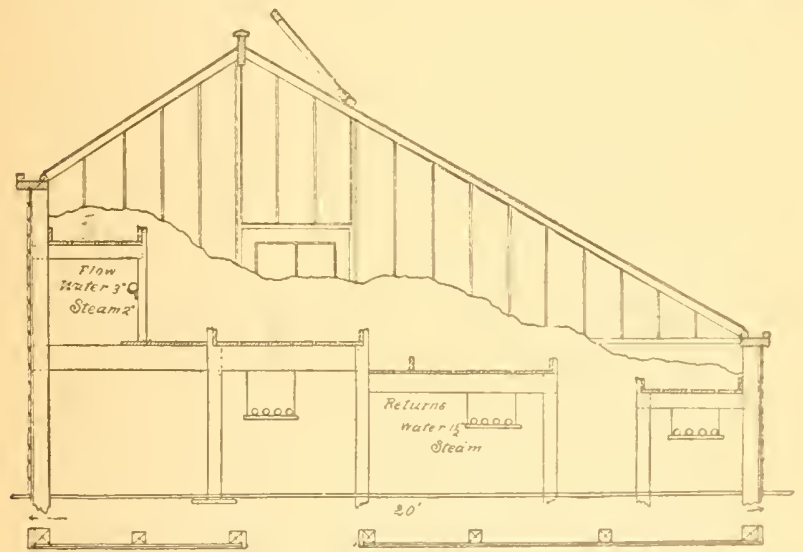

FIG. S:. SECTION OF ROSE IIOLSE (WOOH).

perhaps the best advice that could be given to a person intending to build a rose house would be, in calie one conld not afford to build a house witle an irom framework, to write to the nearest dealer in cypres lumber for plans and estimates for the proposed strueture.

As a partial guide in the matter, the following estimate is offered as the probable cost of cypress lumber for the erection of a three-quarter span rose furcing house. This includes all lumber required abore the walls for a house with one gliss gable; the lumber being 
dressed upon four faces and worked to proper shape with dimensions as given, including door and one row of rentilator's.

ESTIMATE FOR CYPLESS LUMEER FOR A THREE-QUARTEL SHAN FURCIXG IIOUSI, 100 FELT HI 20 FELT.

\begin{tabular}{|c|c|c|c|c|c|}
\hline Gable l'late, & $1^{3}{ }_{4}^{\prime \prime} \times 7 "$ & $20^{\prime}$ Jong & (11) & $0.071 / 2$ & $\$ 1.50$ \\
\hline Sitle fiutters, Bo & Bottoms and two sicles, & $200^{\prime}$ & « & $.11 \frac{1}{2}$ & 23.00 \\
\hline Rillge l'ieces, & $7^{1 / 2} 2^{\prime \prime} \times 1_{4}^{3}{ }^{\prime \prime}$ & 100 & (1) & .08 & 8.00 \\
\hline Riclge Cap, & $1^{1 /} / 8^{\prime \prime} \times 3^{1}{ }_{2}^{\prime \prime}$ & $100^{\prime}$ & $\bar{v}$ & $.021 / 2$ & 2.50 \\
\hline Purlin, & $1_{4}^{3}{ }^{\prime \prime} \times 3^{1} z^{\prime \prime}$ & $100^{\prime}$ & (i) & $.031 / \frac{3}{2}$ & 3.50 \\
\hline End Rafters, & $\left.\begin{array}{rl}13 t^{\prime \prime} \times 3^{\prime \prime} & 2 \text { of } 7^{\prime} \\
2 \text { of } 16^{\prime}\end{array}\right\}$ & $46^{\prime}$ & (ü & $.03^{1}{ }_{4}$ & 1.61 \\
\hline Gable Sasl IBars, & For one gable, & $80^{\prime}$ & (a) & $.01_{4}^{3}$ & 1.40 \\
\hline Roof Saslı Bars, & $\left.\begin{array}{l}82 \text { of } 7 \\
82 \text { of } 16^{\prime}\end{array}\right\}$ & $1,8 \times 6^{\prime}$ & a & $.02 L_{4}^{\prime}$ & .4 \\
\hline Heacler, & $1_{4}^{3}{ }^{\prime \prime} \times 21_{4}^{\prime \prime}$ & $100^{\prime}$ & 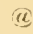 & $.021 \%$ & 2.50 \\
\hline Ventilators, & $3^{\prime}$ widle $13 / 4^{\prime \prime}$ & $100^{\prime}$ & (a) & .16 & 16.00 \\
\hline Dool and Frame, & \multicolumn{4}{|c|}{ Door $3^{\prime} \times 7^{\prime} \times 11_{4}^{3 \prime \prime}$} & 4.75 \\
\hline
\end{tabular}

For the construction of the walls twenty-six posts seven feet long, and costing abont twelve cents each for cedar, and twenty-one posts twelve feet long, which will cost abont twenty-five cents each, or abont ten dollars for posts, will be required. Red cedar will cost two or three times as much, and locust, which will be found very durable, will vary in price but will generally cost less than red celar. For sheathing the building 1,300 feet of matched hemlock, eosting from $\$ 10.00$ to $\$ 15.00$ per thousand, will be required, and the outside siding will take 1,500 feet, which will cost about $\$ 20.00$ per thonsand. A small amount of finishing lumber, building paper and nails will complete the exterior, with the exception of the painting and glazing. The interior will require tables and walks, gas-pipe posts and ventilating and heating apparatus, which, with hinges and other hardware fol door and rentilators, will cover the necessary materials for the election of a forcing honse.

The cost of the lumber will be about $\$ 230.00$; glass, 2,500 feet at \$3.50 per box for double strength B, $\$ 1 \% 5.00$; rentilating apparatus, $\$ 30.00$; nails and hard- 


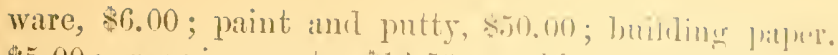
$\$ 5.00$; gals-pipe posts. \$1 12.50 ; making al futil rost of materials for the lonse, exclusire of lallor, uf albunt

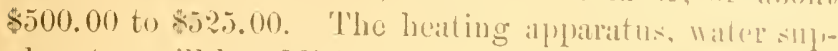
ply, etc, will be artilitional. 'T'he former will (nst, abont $\$ 400.00$ if hot water is llsed, and not fal from sito.(1) for steam, including labor. It the lunse is erected by hired labor the cost will be from s.250.00 to s.300.00 for the earpenters and painters, aleoroling lo the experience of the men and the wages paid.

Brictly summarized then, the cost of a three-ynarter span foreing house complete with louting alplatritus will be:

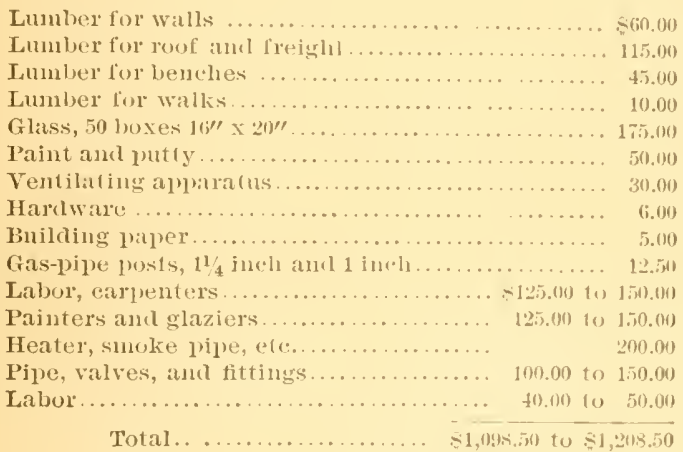

$0 \mathrm{r}, \$ 11.00$ to -12.25 per linear fonl.

In the above estimate, the grading, drainage, water supply, and the cost of a putting shed, funnce cellar, etc., are not considered. Of course, the cost of the lumber and the expense for latror, ete., wonld rary in different localities, so that no estimate can be mate that will apply in all catses, but where lumber ean be olftained at from $\$ 1 \% .00$ to $\$ 20.00$ per thousind, alecording to the grade, and labor of carpenters and painters is not orer $\$ 2.50$ per day, the albore will be sulticiently reliable to furnish a fair idea of the cost. The cost of an even- 
span house will be abont the same, and, if the back wall has to be built for a lean-to, it will cost fully as much as the other's for the same width of house. In this estimate orer $\$ 300.00$ is allowed for labor, and as many florists would do most of the work themselves, a considerable rednetion could be made in this item.

\section{CHAP'TER MXIV.}

\section{IETTUCE IIOUSES.}

Although we still find many growers of lettuce using houses of lean-to or narrow even span construction, the wide houses are rapidly superseding them. Perhaps the largest house ever erected for the purpose was constructed by W. W. Rawson of Arlington, Mass., who has been engaged in the growing of lettree and other garden produce for the Buston market for many years.

This house is three hundred and seventy feet long and thirty-three fect wide. It is of the three-quarter spim form, and measures fifteen feet high at the rillge, with a sonth wall three and one-half fect high, and the north one twelve feet in height. The glass is double strongth, twenty by thirty inches. The crop from this one house is abont two thousand dozen heads, which somctimes brings from $\$ 2,000.00$ to $\$ 2,500.00$. Three crops are grown in a year besides a crop of cucnmbers. While this is the largest house of the kind, there are many smaller ones construeted upon the same general lines, and they seem to be uniformly successful.

\section{LEAN-TO LETTUCE HOUSES.}

The lettuce is a plant that succeeds well in a lean-to lettuce house, such as is used by many of the lettuce 
grower's in the vicinity of Boston, of which a cross seetion is shown in Fig. S:). Like all leall-to hondes these are casily warned and are cheab)ly eomstructed, but lhey do not have a sufficient pitcle to the ronl to secule the most benefit from the sull. They ane (onmmonly groen at piteh of abont eighteen degrees, but even at this slope, a lean-to roof on a house thirty-three feet wille would require a north wall about fifteen fees high, while a three-quarter span louse can have a pitch of trenty-1 wo degrees, and the north wall need not be orer ten or twelve feet high.

With houses mp to a wiath of twenly-five feet, i proper slope can be secured without carrying the nortl:

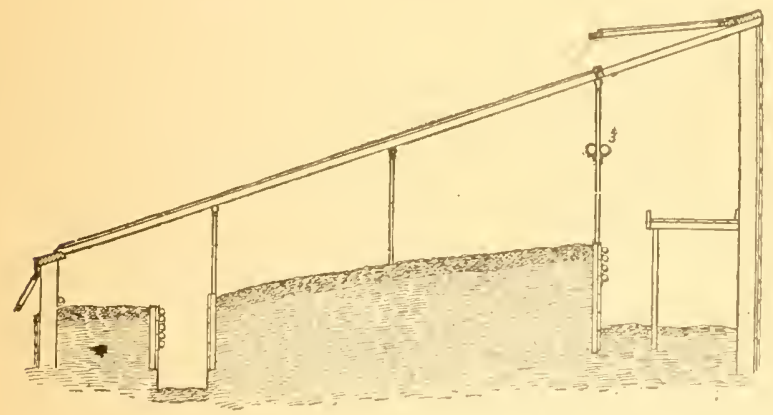

FIG. 83. LEAN-TO LETTUCE HutSE (Suction).

wall to an unche height, or ratiug the glass too lighl above the plants; muless njum a siclehill, this wilth cannot be rery much excederl with this style of luntse.

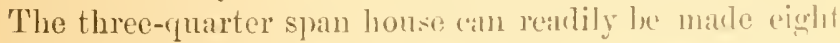
or ten feet wider than the han-to, without arrying the roof to a greater heighl, while the north wall will lu considerably lower than it would he in the lean-to. II alling determined npon the wilth and style of roof tor the house, the construction will be rery simple, if the sur- 
gestions given in Chapters V. and VI. as to the best methods of erecting the walls and roof are followed.

Lettuce houses should have from eighteen to thirty inches of glass in the sonth wall, and, on many accounts, it is desirable that the alternate sash at least be arringed as ventilators. Partienlarly in the wide houses with flat roofs, the sash bars should be somewhat heavier than for small houses with steep slopes, and should be rery carefully supported. For lean-to houses twenty-fire feet wide, there shonld be at least three rows of purlins and purlin posts.

A house of this description will require a back wall at least ten feet high, if built on level ground. A post and double-boarded wall will be fully as satisfactory as one built of brick or masonry of any kind. For convenience in handling the soil, and to assist in rentilation, it is well to have small windows, perhaps two and onehalf feet square, onee in ten feet, in this wall. When solid beds are used, the south wall should not be more than three and one-half feet high, although it may be somewhat higher if the lettuce is grown in raised beds.

The side-hill houses (Fig. 8) will also be found quite desirable for lettnce foreing, as they are nothing more than a number of lean-to lionses placed close together, and they will be found not only economical in construction and heating, but in land and in labor of handling the crops, althongh the three-quarter span houses are generally preferred to either of the above styles. 


\section{OILAPTER EXV.}

IROPAGATINY HOUSE.

In comnection with erery greenhonse there should be a bench for the rooting of enttings, and in large establishments one or more honses will be required for this purpose. 'The simplest method of ereeting a propagating bouse, when one hats a rose or other threc-purarter span house, is shown in Fig. 61. The strnetme is known as a "morth-side honse," and, if it is not entirely needec? for propagating purposes, can be utilized for ferns, violets, and other plants that thrive withont direct sunlight. In arranging some establishments, a narrow house, connecting the ends of the main houses, is often a convenience. If upon the north, or even on the cast or west ends, as it generally in, this head honse can he mide seven feet wide, with il lean-to roof, and will serve :m cxcellent purpose as a propagating honse. When any of these locations cannot be utilized, a narrow even-span honse can be used for this purpose, and will be well adapted for it.

The construction of the house will not differ from that of a similar honse for other purposes, lunt its interior arrangement should he somewhat different. As a table for a propagating house, an orlinary sreenhouse bench will answer, but, in order to secure and control the necessary bottom lieat, the front of the bench should be boarded ip), with one board on hinges so that it can be nsed to regnlate the temperature. For the projagation of most plants this bench will answer is well as a 
more elahorate construction. The heating pipes should all be muder the bunch, and shomld give a raliating surface about twenty-five per cent. reater than would be required in a growing louse for the same plants as are to be propagated.

\section{WATER BENCH.}

The use of the old-fashioned wooden water bench has been abandoned, although the galvanized iron water bench is quite common. If this is nsed the trongh should be about four inches deep, and of the width and length of the proposed entting bench. It should be well supported, so that there will be no danger of its settling at any point. The bottom of the entting bench, npon which the sand is to be placel, shonld be just above the tank. The tank should be commected at each end by means of one and one-fourth inch pipes with a lot water heating apparatus. When the heating pipes in the system are all below the level of the tank, no cover will be required, but, if at any point the piping is orerhead, a elosed tank will he necessary, or an independent heatel ean be used for the propagating house, in which ease the water tank will answer as the expansion tank for the system. When tanks are used, the heating pipes should be sufficient to maintain a temperature of forty-five to fifty degrees without the tank.

\section{PROPAGATING CASE.}

While cuttings of most plants require thorough ventilation, many stove species can only be struck with suceess in a close, moist atmosphere. When only a few are to be rooted, the roquired conditions ean be seenred by the use of a bell glass, or hand glass, but, if many are to be struck. a propragating case will be a necessity. This can readily be construeted npon the benel, preferably at the warmer end. 'The ends and frout can be 
made of sush bars and gliss. A portion of the fiont,

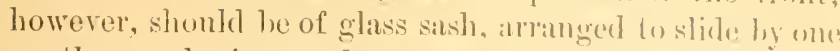
another and give ready alecess to all pards of the calse.

\section{CHIT'TER XXVI.}

\section{HOTBEIS.}

Among the movable plant structures, we have what are known as hotbeds and cold frames. "They difler only in the degree of heat they receive, the cold frame being withont artificial heat, while the hotber is heated by fermenting regetable sulustances, generally stable mamue, leaves, and other refuse. 'The hotbed, in some of its forms, is a very desirable, and, in fact, almost a necessary atjunct to the greenhouse, for all florists and market gardeners. On the other hand, while a large business can be carried on with

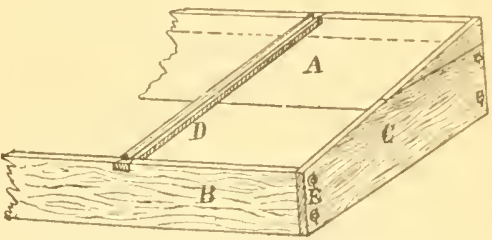

FIG. St, HOTBEI) FR.LME. hotheds alone. the possession of a greonhomse, small aml cheaply construeted thomgh it loe, will be al creat (onvenienee, particularly to the market gardener. for the starting of yomng plants during the serere wrillere of milwinter.

The simplest kind of a hotherl, and the one gremerally used, is about six feet withe and of any desireml length, with the sash shoping foward the south. While hotbeds are often macle of onc-inch bualds. wre are cheaply eonstructed of waste pieces of lnmbers they will be more satisfactory if comstructed of lumber that is ome 
and one-lualf or two mches thick, carefully framed together and painted. A rery satisfactory hotbed can be made from three pieces of two-inch hemlock lumber one foot wide and twelve feet long. In order to give the sash a proper pitch to the sonth, one side of the bed shonld lye made six inches wider thin the other. When planks with a width of twelve inches are nsed this can be readily secured, by sawing a strip three inches wide from the edge of one, and nailing it to the edge of another, Fig. S4. In this way we secmpe a plank nine inches wicle $(B)$ for the sonth sicle of the bed, while that for the morth side ( 1 ) will have a width of tifteen inches. The ends should be cut six feet long, and the proper slope can be given them by sawing off a triangular strip from one end, and nailing it npon the other end of the piece, as at $C^{\prime}$, in Fig. 84.

PORTABLE FRAMAES.

A portable hotbed frame is often nsed, and as it can be taken apart and stored out of the sun and rain for

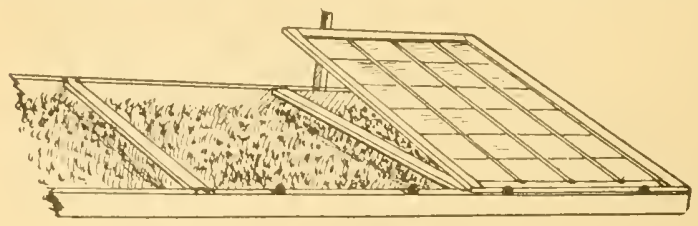

FIG. 85. FRAME IND SASII.

six months of the year, it will last for many seasons. By fastening irons of jroper shape to the ends of each of the side boards, and boring holes to correspond in the end pieces, the frame can be held together by washers and pins, as shown at $E$, Fig. 84. Cross bearers, D, four inches wide and one inch thick, dovetailed into the edges of the front and back boards. will keep the bed from spreading, and will serve as slides for the 
sash. If a strip of one-inch bourel is fistened to the

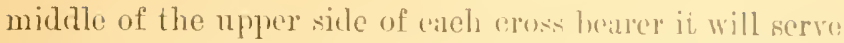
to strengthen it, and to hohl the sash in place. Another method of rentilating the hed is illustrated in lije. . . . For the prupose of retaining the heat in cold weallere, straw mats and wooden shutters are desirable.

\section{MATS AND SHITTLRS.}

For the mats, a supply ot long reve straw, tarred rope, and strong linen twine ale necessury. 'l'here alde various ways of making the mats, one of the simplest being upon a frame of two hy four incly lumber of the same size as the mats. With long siraw, a mat six and one-half feet square can be made, but the usual size is

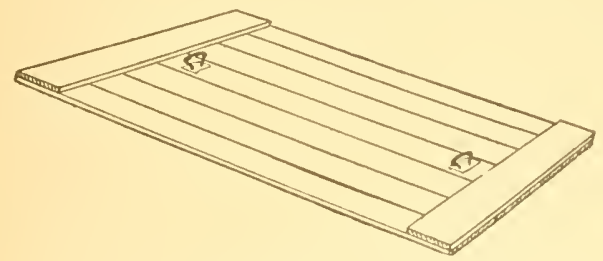

FIG. S6. HOTBED SHL"TTER.

about four, or five, by seren feet. 'The tarrerl rope is stretehed leugthwise of the frime, so als to loring the strands one foot apart and six inches from earh side, and fastencel to stout pegs. For a mat six and onc-lialf foct square, the stratw should be, at least, four feet long. Bundles of straw as large as cam be melosed by the thumb and middle finger, are placed on the frimne, with the butts even with the sides, and are tiod in place with stout hemp twine. The bundles thus litp in the ecnter about two feet, and the ends will kecp the center even with the sides. With striuw still longer tham this, a mat about fire feet wide can lee made without any lang of the straw, by placing the butts alternately to the right and 
left, one length of straw reaching across the mat. If the mats are kept eorered with the shutters, and are stored where the mice camnot destroy them, they can be used for many years.

'The shutters, Fig. 86, for corering the mats should be six and one-half feet long, and three feet to three feet and six inches wile. Made of half-inch matehed lnmber, with cleats at the ends and across the middle, and with handles. they form a useful addition to one's equipment.

\section{IIOTBED YARD.}

Unless they can be placed where they will be sheltered by buildings, a tight board fence upon the north,

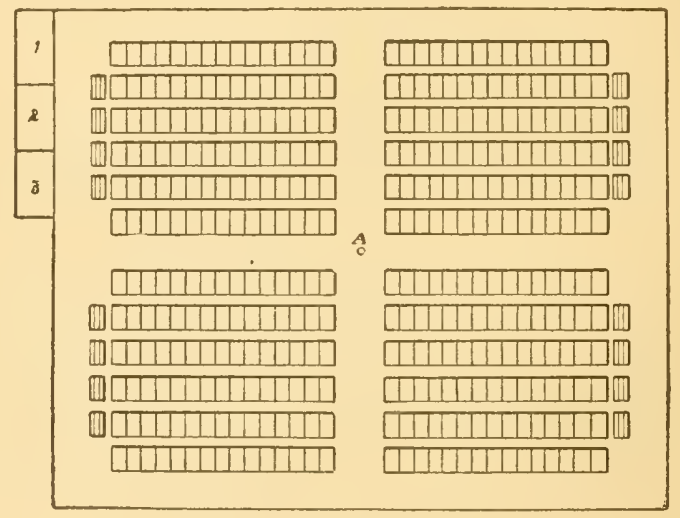

FIG. S\%. HOTBED TARD.

east and west sides will be desirable. The land shonld, if possible, slope slightly to the sonth, and the rows of frames shonld be regularly arranged. In Fig. s\% will be seen a conrenient arrangement for a frame yard. There is an opportunity for a team to pass entirely around the frames, and throngh the center in either direction. There should be a hydrant for furnishing water at the 
eenter of the plat, 1 , or at some of her andrendent puint.

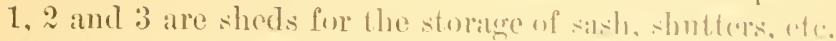
If one has but a fow frames it will be lesirable to halle them seven feet apart, which will give slatee for the silsh to be drawn off, and will allow a eatet lo dinmp ils loakl of mamure or soil between the frames. Whien a larere number of frames atre nsed, and esperoblly if tho lambl is raluable. it will be better to have the rows from two bo three feet apart. The shutters and siak wan llan be placed in piles at the cond of the rows. If only at small amount of rentilation is neederl, the satsh ean be slipped up or down, or can be raised, als serm in Figr. 8i.

\section{M.IKING THE BED.}

For a winter lotberl, the heating material should have a depth of from two to fwo and at lialf feet. While in the spring one-half that depth will answel. In ("xiatration two feet wider than the frame, and of the reppuires depth, should be mate, in orter to prevent the frost from working into the bed, although for spring uso the same result may be effected by piling fresh manure alout the frame. The heating material is generally fresh horse mannre. Unless it contains a liberal anumnt of straw, or similar bedding material. something of the kind shonkd be alded, so that it will mot be more tham one-half of clear manume. Oak leares, also, make a good material to mix with the mannere, at they will hiniler, and. eonsequently, prolong the decomposition of the mass, thus giving an cren heat.

About two weeks before the berl is wanted, the material should be placed in a pile aluent right feet will. and four feet high, with a flat, top and bertical sillw. The pile should preferably be male in a slede or matumer cellar, but may he in the open air, or eren in the frame itself. In three or fom days it will be formenting ralpidly, and should then be forkerl oret, throwing the ont- 
side portion to the center: at the end of two or three days the pile should be well rarmed up, and the bed may be made, or, if it has not warmed evenly, it should be again tmined orer, before being placed in the frame. In working orer the pile, all coarse lumps should be broken up, and the heap should be left as light as possible, to enconrage fermentation. If, when the material is placed in the frame, it is quite warm, it may be lereled off and firmly tramped down, filling it up to within six or eight inches of the glass. Should it not be as warm as is desirable, it may be bost to delar the final tramping for a comple of days.

'The bed is now realy for the soil, which shomld be a rich compost. For many crops the soil and manure

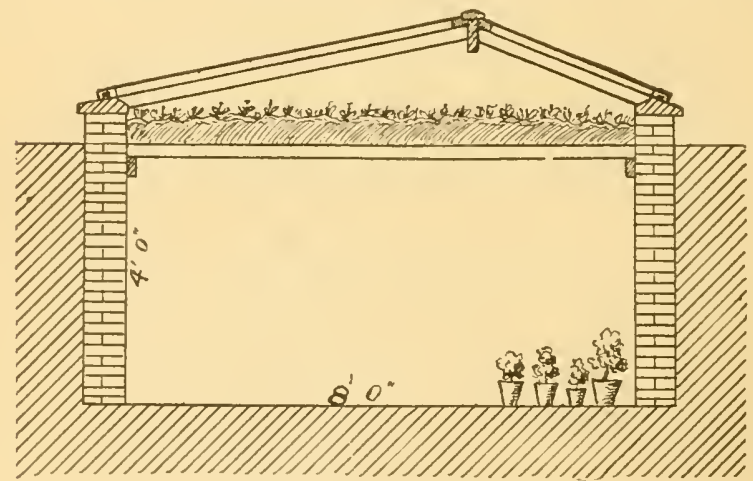

FIG. 88. COLD PIT.

from an old bed will answer. The best materials wonld be equal parts of pasture sods, decomposed manure, garden soil, and sand enongh to make a light mass and prerent baking, spread orer the manure to the depth of six inehes. For two or three dars there will be a violent heat in the bed. but this will soon go down and the bed will be ready for seeds or plants. If, while preparing 
the manure for the bed, it is formel to be dry, it slumlu be moistened with tepid water from a watering ran.

In earing for hotheds, the mats and shutters shonle! be taken off on pleasant days, as somon ats thes stm is well up, and on bright days the beds shonlel he given air about the same as in at foreing house. The berls should be elosed, at least, two hours before sinsel, and the onsers should be put on as the sun goes down.

While hotbeds are al great convenience after the first of Mareh, they are each year becoming leis user for the growing of winter crops. The cost of foreing honses is: but little more, and they are much more convenient and in every way more sitisfictory.

\section{DETACHED COLD FRAIEN AND I'ITS.}

The most common form of coll frame (a hotbud frame and sash withont any leating material) is a low structure used to carry through the winter pansies, violets and other half hardy plants, or foi the growing of vegetables and bedding plints, before the dinger of frost in the open ground is orer in the spring. For many purposes, howerer, a deep frame or pit is clesirable. In Fig. SS is a cross section of snch a structure. If made eight feet wide inside, five or six feet deep at the plate, and of any length, it will be fomd one of the most useful "rooms" in a greenhonse extablishment. The walls may be of wood, brick, stone or concrete, and the top should consist of plates, firmly anchored to the walls, a ridge, rafters and hotbed sish. For al pit right feet wide inside, the sash on one side shonld be abont six by three feet, and on the other fonr hy three feet, wr if ten feet wide, an eren spran roof cill be male, with salsh six by three feet on both sides. With mits and shutrexr, frost ean be kept out from at deep pit of this kind. L: in Fig. 88, a double use cin be male of surth at frimne. By placing a plank floor abme one fout helow the plite, 
the upper portion can be used for violets and similar plants, while bulbs for winter forcing can be plunged in sand upon the bottom. It can also be used for wintering a great variety of plants. In Fig. 10 can be seen a rery convenient frame against a greenhonse wall. By means of slides in the wall, a sufficient supply of heat can be admitted from the greenhouse if desired.

\section{UHAL'IER XXVII.}

CONSERVA'TORIES.

As usually inplied, this term refer's to small greenhonses attached to dwellings, in which, although plants may be grown, the real object is to have plants shown that are attractive, either in foliage or Hower. In a strict sense, however, a conservatory is a structure in which plants that have been developed in narrow and comparatively low greenhouses, known as growing houses, are shown during their period of flower. They may be attached to the dwelling or other building, Fig. 89, but are gencrally detached buildings surromed by the varions growing houses. In another ehapter descriptions will be found of various small structures adapted to the wants of amatenrs, but at present we shall consider varions combinations of glass structures, consisting of conservituries or show houses, with the necessiry subsidiary growing houses, snch as would require the care of a professional gardener.

In addition to the large number of public institntions where large conservatories are desirable, the number of private individuals who have the means to erect and maintain establishments of this kind, and taste to ippreciate the beanties of the flowers and plants grown 


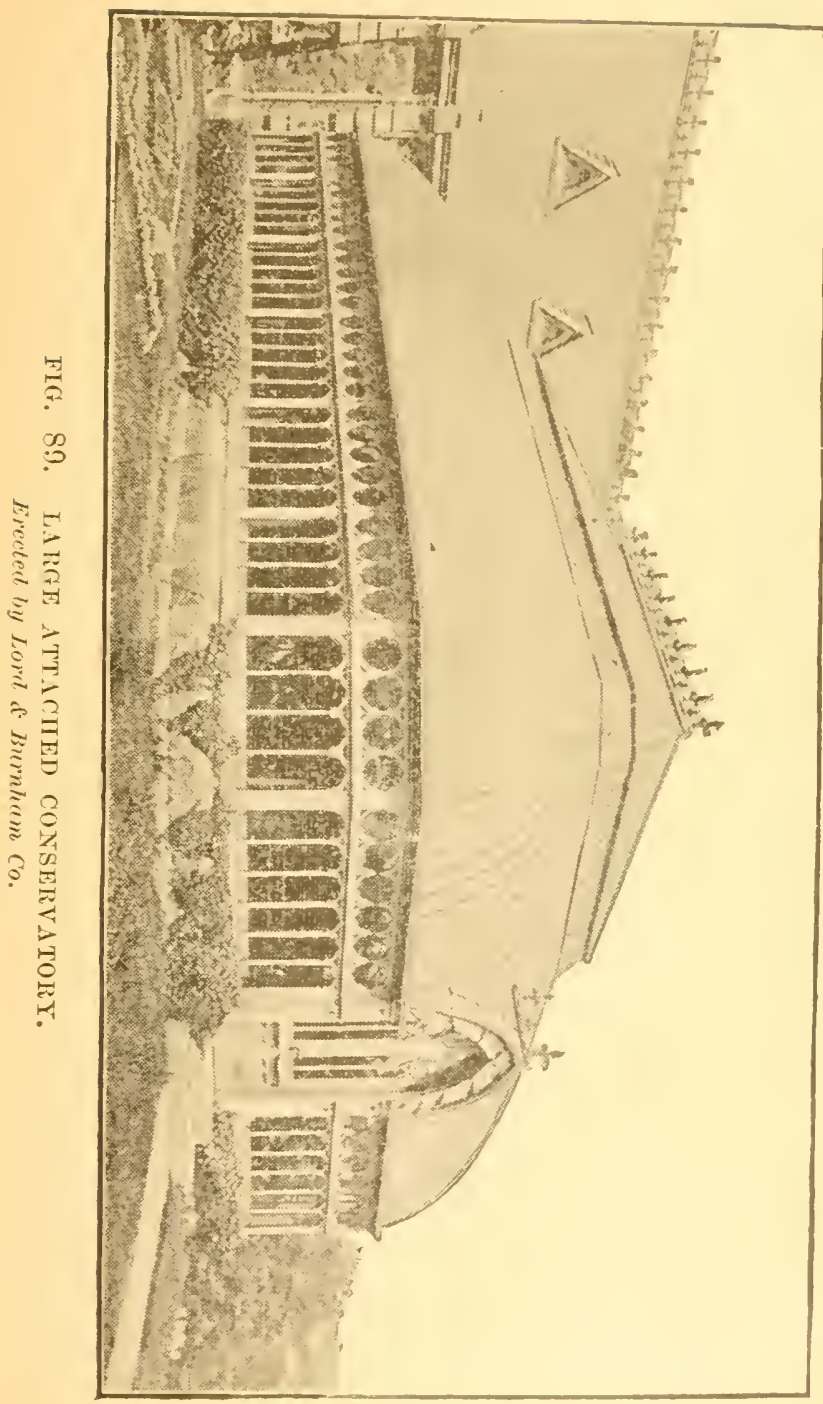


in them, is constantly increasing. 'The use of plants for purposes of lawn and honse deeoration, and of flowers for enbellishing the table, the parlor, or the person, has become so eommon that whele one can afford it, the possession of a greenhouse has beeome rery desirable, and almost a necessity in some cases.

Conservatories, in proportion to their length, are much wider and higher than the growing houses, and, in fact, there is practically 10 limit to their size, except the money to erect and maintain them. They are usually crected rpon a brick or stone fommation about two and one-half feet high, and with vertical glass sides above this to the height of from six to ten feet above the masonry. 'The wilth of the house may vary from twenty or twenty-five feet, to eighty or one hundred and even more, and the length may be as desired. For narrow honses, up to a width of thirty feet, the even span roof with straight rafters, continuous from rilge to plate, will be the least expensive ; it will grow the best plants, and, if made in proportion, will not be displeasing.

For a house of this kind the slope of the roof should be about thirty-five degrees. Twenty years ago it was the custom to surmount conservatories of this kind with a lintern top abont six feet wide, Fig. 90, two feet high at the plate, and three at the ridge, ruming the length of the house. 'These had ventilators in the side walls, which were desirable in summer, but during the winter they alled greatly to the consumption of fuel. 'The lanterns were so narrow that they were of little use, except to add, in a slight degree, to the appearance of the honse. They are now no longer nsed except upon very wille conservatories, where they are so constructed, as shown in Fig. 91, that they add from five to ten feet to the height of the house, and are of such a widtli that this space caun be utilized by tall plants. The straight sash bars can also be used in wide houses, but they will 


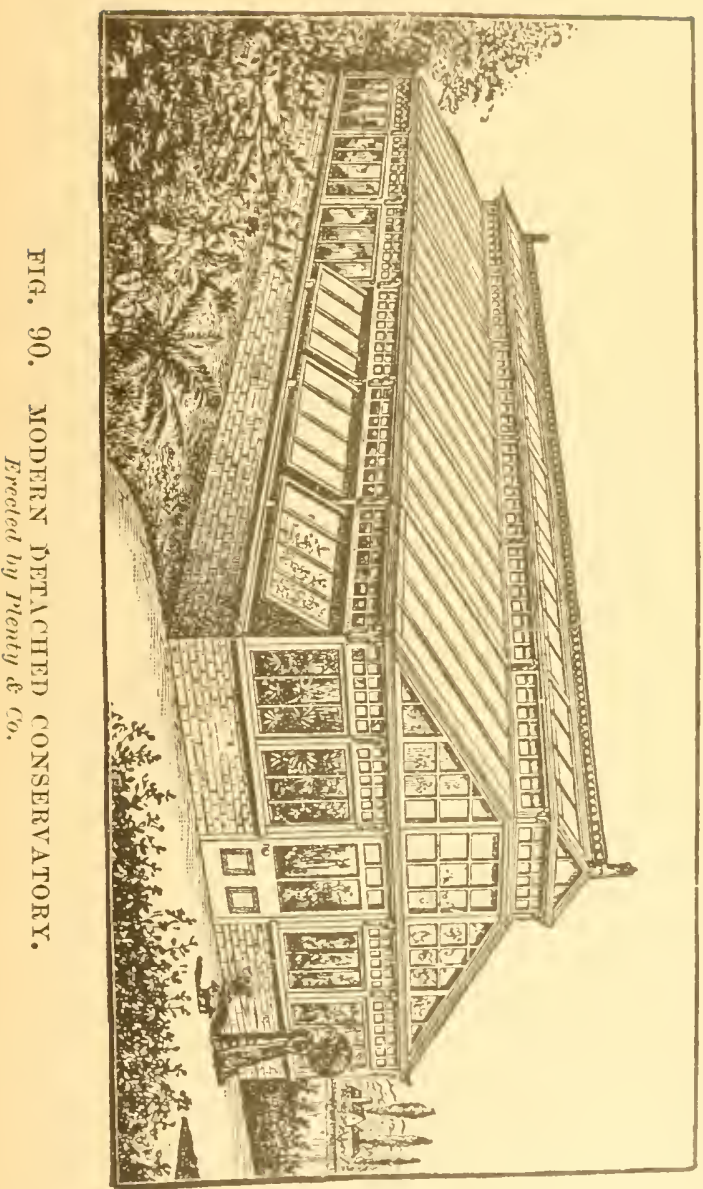


Lave a barn-like alpearance, mnless the roof is broken by gables and secondary slopes. This method of building greenhouses has many things in its firor, that are worthy of commendation. It is in the wide conservatories that the curvilinear roofs are particularly desirable. In themselves they are quite ornamental, and they moreover

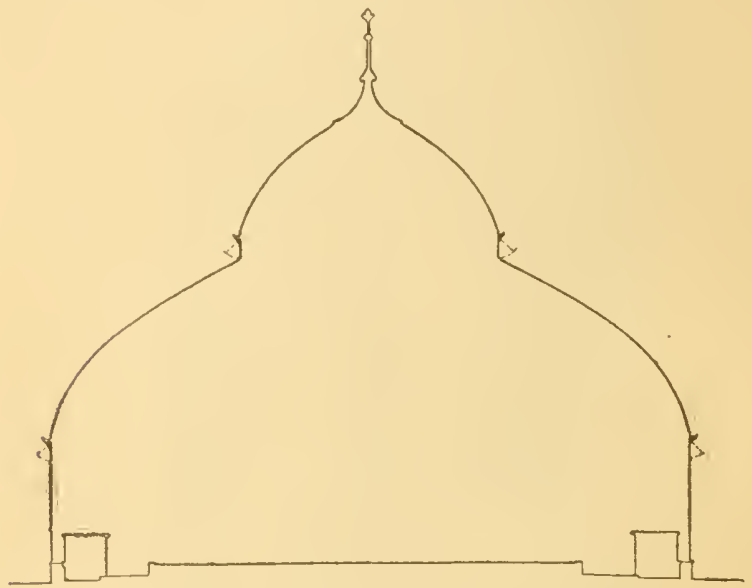

FIG. 91. Coxsertitory (Section).

form a convenient methor of arching orer any wide space, as shown in the eross section, Fig. 91, and in perspective in Fig. 105.

\section{ILON HOTSES.}

For any structure of this lind, wool is too perishable, and the necosiary strength could only be secured by the une of a heary framework. Of all materials at present availible, architecturil iron seems best adapted for this work, and all sills, posts, rafters, braces, ridges, purlins and supperts shonld he of this material. There scens to be but little choice between cypress and metal sash bars for large conservatories, aside from the larger 


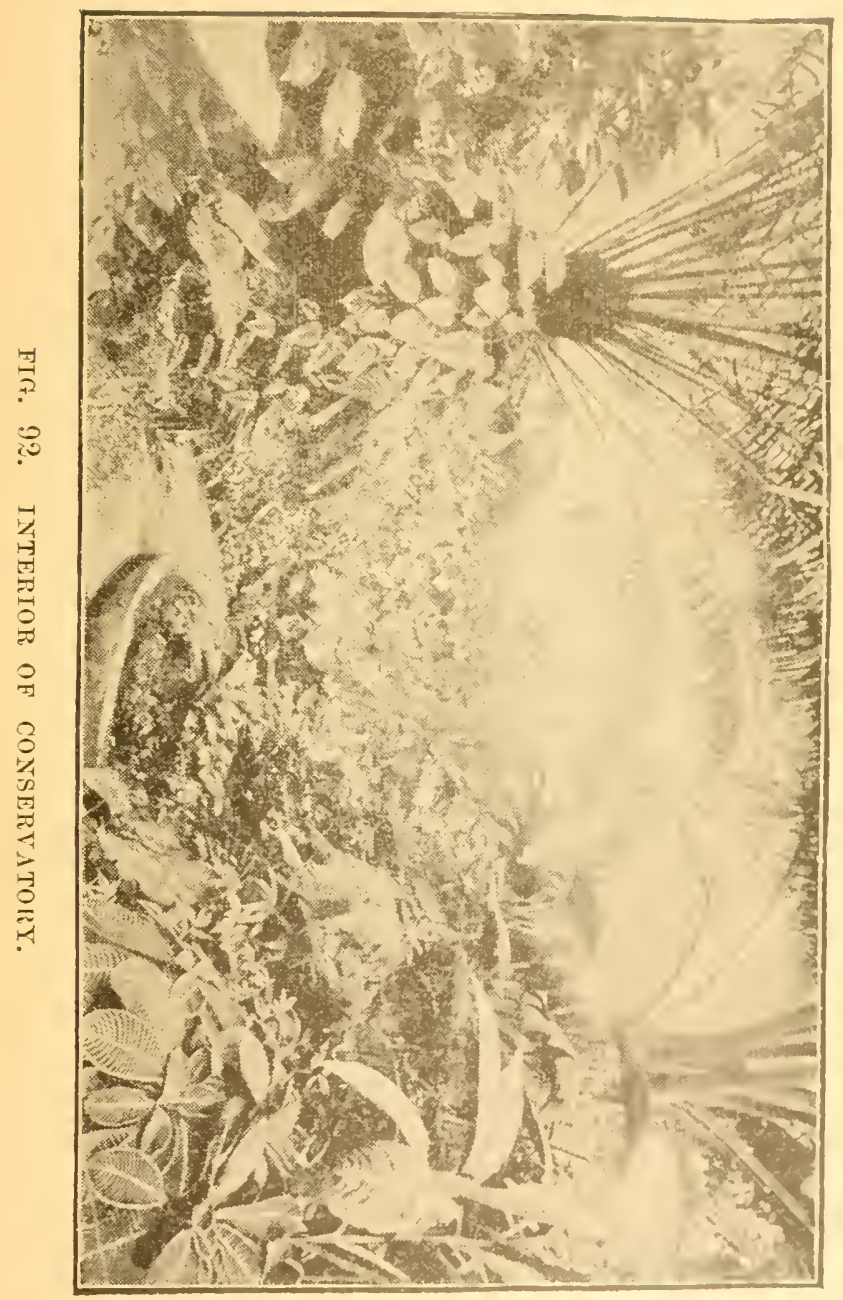


expense that must be incurred for the latter. If the latter are used, it is desirable that they shomld have a steel core, as, if constructed of copper, zine, or galranized iron. they are likely to bend and crack the glass.

'The first cost of the iron roof is considerably more than for cypress, and, in order to be lasting and frec from rust, it will need to be painted fully as often. A metallic glazed honse is harder io heat than a putty glazed one, and after a year or two is likely to leak heat from, and rain into the honse. With the same attention to painting and repairing al wooden roof at is necessary with an iron one, the house will be tighter, easier to heat, there will be less drip, and it will be in a good state of preservation at the end of twenty-fire or thirty years. Althongh practically indestructible, the glazing strips used in the iron houses will hare become so bent and ont of shape that many of them will require renewal even before this time.

\section{INTERIOR ARRANGEMENT OF THE CONSERTATORY.}

In arranging the interior of the conservatory, it will be well to use all of the center of the building for large palms, bananas, bamboos, tree ferns, and other tallgrowing plants, Fig. 92. They shonld be planted in the ground, and so arranged as to present as natural an appearance as possible. The walks shonld be of generous widths, and so arranged as to bring into view all parts of the house. The portion of the house next to the walls may be arranged in the same manner as the center, but it is desirable to lave a jortion of it, at least, supplied with tables, upon which plants in flower may be displayed. If they are combined with ferns and ornamental-leaved plants the effect will be very pleasing. This is really the purpose of a conservatory, since, as is uswally the ease, if it is kept at a temperature of fiftyfive to sixty degrees when plants are brought in from 


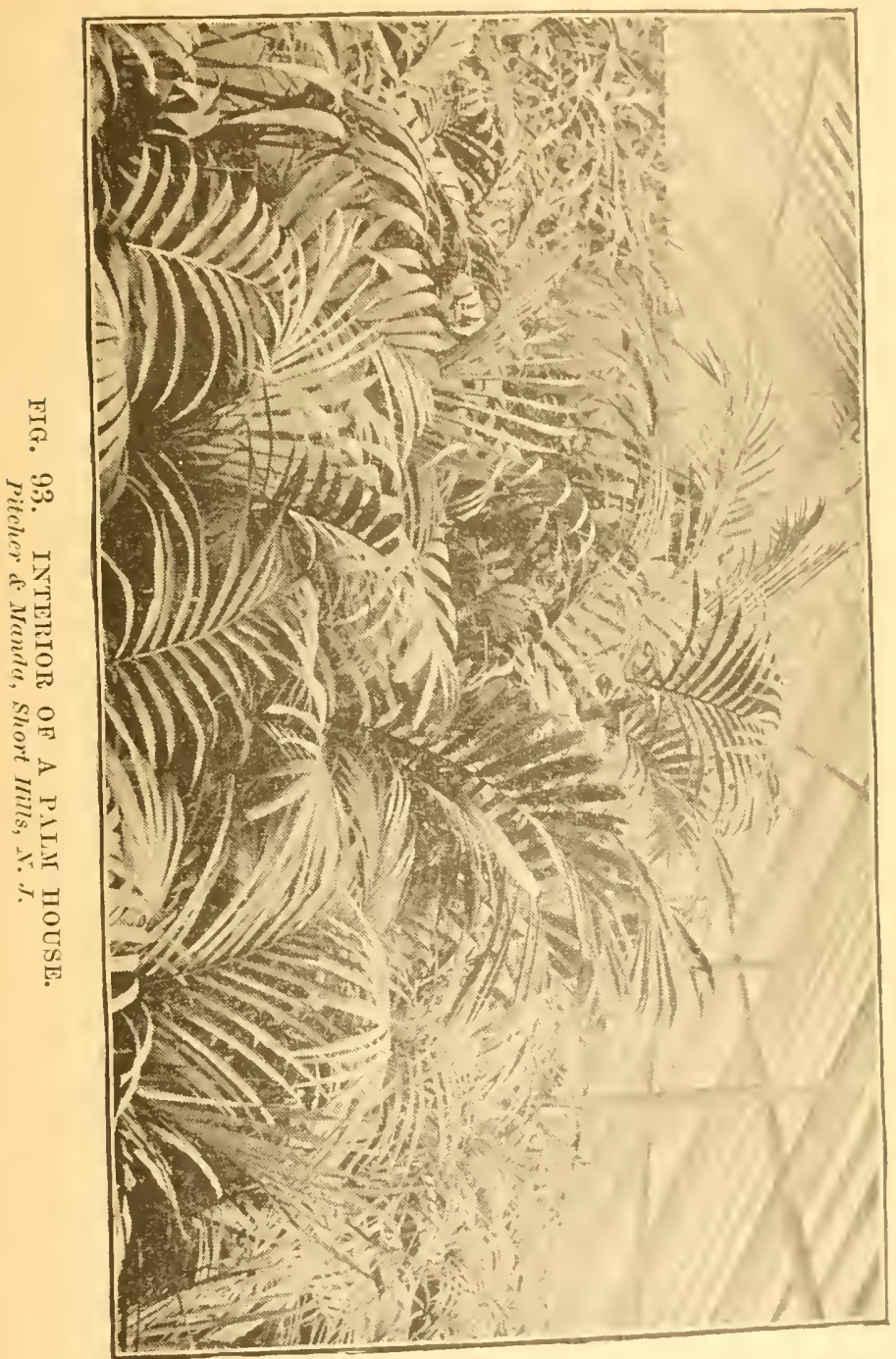


the stove and other wilm rooms, the flowers will be conserver, and will last must longer than if kept at a high temperature. Freenently the large rooms are used for growing collections of the more ornamental palms, and are known as palm lionses, Fig. 93.

\section{THE STOVE IIOUSE.}

As first nsecl, the term "store" was applied to greenhouses in which artificial heat was supplied by means of stures. As is frequently the case, the name of the object becime attached to the building in which it was used, and a store house to-day is merely a hothouse with a temperature of sixty-five to seventy-five degrees. As a rule, these are considerably narrower and lower than the eonservatories or palm honses. They are sel-

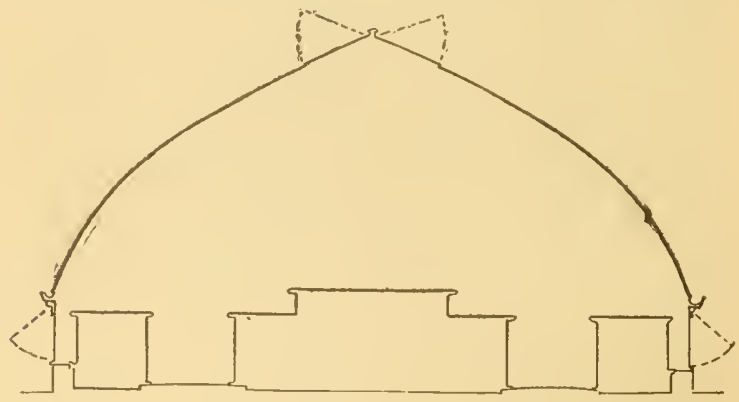

FIG. 24. STOVE room (Section).

dom wider than twenty or twenty-fire feet, and from twelve to twenty feet in height. If built njon a masonry fonmlation two and a half feet high, the vertical side walls are nsually abont two and one-half or three fect high, with side rentilators. The roof has an angle of thirty to thirty-five degrees, with rentilators on each side of the ridge.

This honse shomld have site tables, and a wide center table nay be used, or, if the plants are large. they 


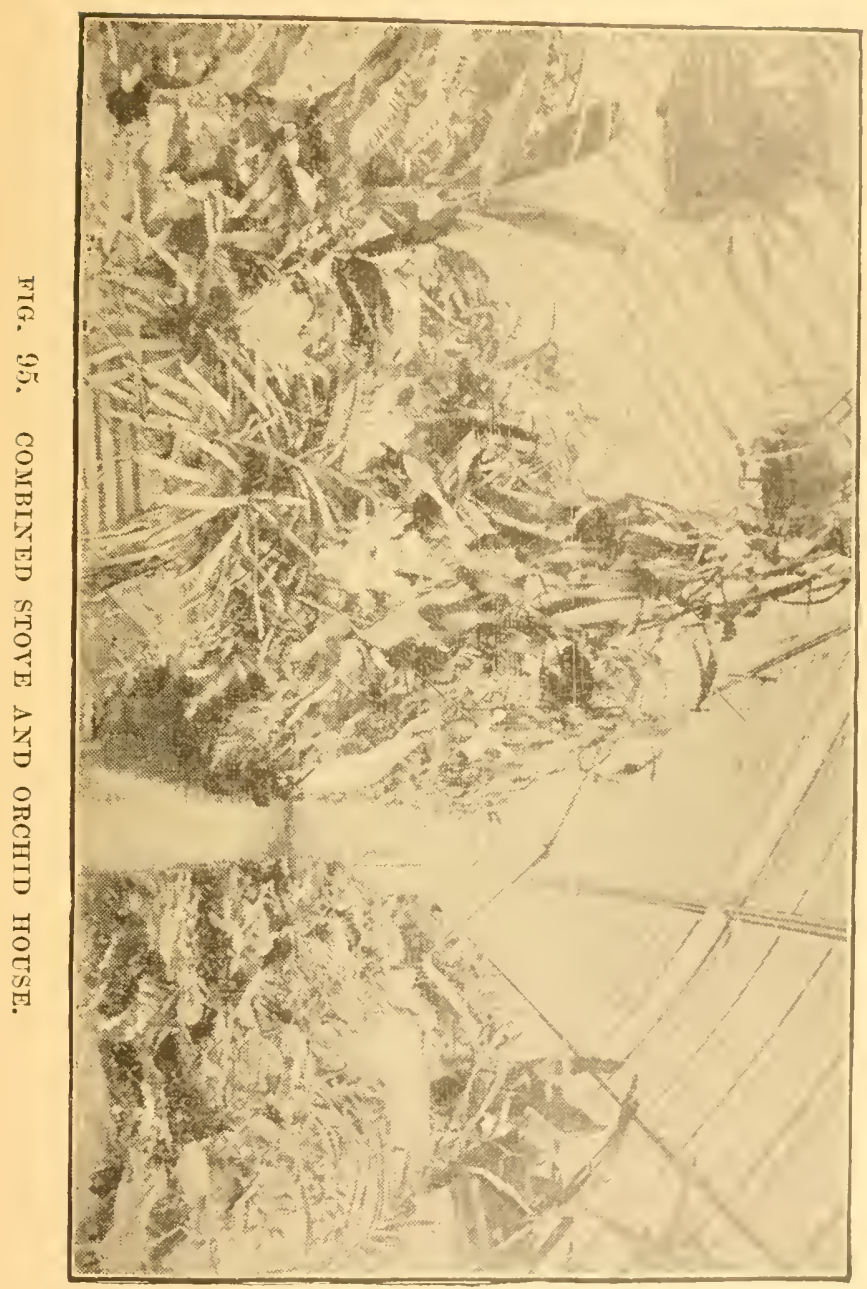


may be planted or plnnged. In Fig. 94 is seen a cross scetion of a store house with al curvilinear roof, while in Fig. 95 an interior riew of the same honse is seen.

When one does not desire the curvilinear roof for itself, a store room built with straight sash bars will give fully as gool results. A rery pleasing effect may be prodnced when stove plants and orehids are grown in the same room. So far as the construction of the house itself is concerned, a stove house does not differ from others of the same general style, except that to obtain the proper temperature, the radiating surface, provided in the steam or water pipes, must be considerably larger than for most houses.

\section{COOL HOUSES.}

In all establishments of this kind there should be, at least, one honse in which a maximum night temperature of fifty degrees is maintained, for such plants as do not require the stove room heat. In a general way, their construction would be the same as for a stove house, althongh, as a rule, a narrower house will answer. There many bedding plants are used for lawn decoration in the summer, a similar house will be rerpired for that purpose. If desired, a portion of this room could be used for propagating purposes, or a narrow house conld be erected especially for propagation.

When large palms, and other similar plants, are user upon the lawns during the summer, they should be stored in a cool house, and if no other place is at hand, a lean-to against a shed or other bnilding can be cheaply erected, and a proper temperature can be maintained at very little expense. For many of the broad-leaved evergreens, that should be kept in a dormant condition during the winter, a north sile lean-to house is quite desirable. 
ORFIIIT IIOTSE.

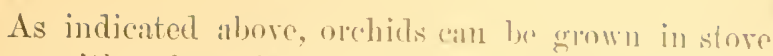
houses with other plants, and for many amatems nu special orehid house need ho provided, butit when the (o) lections are linloge, it will be well to have honsess sed alpalt for their use. It is generally artmitred that, no form of comstruction is better aliupted for orchid enlture than the span loof house. Miny growers have marle the mistake of erecting high and wille houses, while, hatrl they confined themselves to structures not over sixteren of eighteen feet wide, and ten or aleren foet high, they

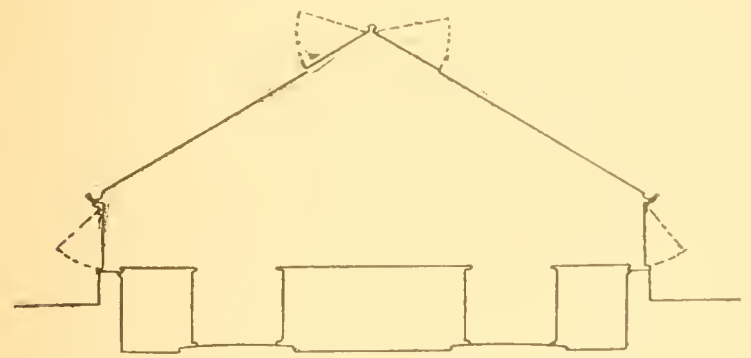

FIG. 96. ORCHID HOI'SE (Sertion).

would have obtained more satisfactory results. to say nothing of the loss in cost of construction and fuel.

The orchids are divicled into three groups,-stove. intermediate and cool house, - from the temperature in which they thrive best. and honses should be providerl accordingly. If an orrhid house sixty to serenty-five

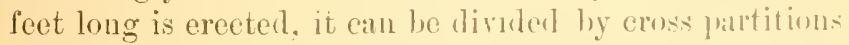
into three rooms, which can be inlapted for the ditferent classes of orehich by a proper aljustment of the heating pipes.

For small plauts, a homse only twolre fect wite and

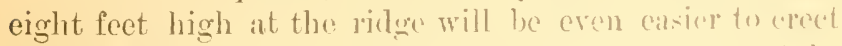
and heat, but the moisturo and temperatme camnot be 
controlled as well as in a wider honse. For some of the cool house orehids, a lean-to honse answers quite well, and where Cattleyas are grown in large quantities for market, the three-quarter span house will give good satisfaction.

In Fig. 96 will be found a section of an orchid house, showing the arrangement of the tables and ventilators. At least two feet of the side walls shonld be above the masonry, giving sixteen or eighteen inches of glass. There shonld be two lines of ventilators at the ridge, and some means of bottom ventilation should also be provided. In the intermediate and Mexican houses the rertical sash in the side walls may be nsed as ventilators, bnt in the stove or East Indian house all drafts of cold air are injurious, and it is preferable to admit the fresh air under the tables.

All orchids recunire very careful shading during the summer. A thin permanent shading may be given in the spring, but the main reliance should be upon blinds or curtains of canvas or netting, that ean be drawn up except while the sun is shining bright. In dull weather a thick permanent shading would be injurious to the plants.

\section{GRAPERIES.}

The large, choice varieties of Furopean grapes are not hardy in onr latitude, and some protection must be provided for them if we are to grow them. Many rarieties can be grown in a glass honse even withont heat, and to such a building the name of "cold grapery" has been given. Some varieties require heat to bring them to maturity, while others can be brought in quite early if started in winter with artificial heat, and for such purposes the "hot grapery" is used, althongh the name "foreing grapery" is also applied to it.

While almost any greenhouse will answer for growing grapes, experience has shown that certain forms are 
better than others. For the forcing gralery nothing seems to be better than the numow leant-to or two-third spam, such is is seen in cross section in lige. 9\%, as it furnishes a warm back wall aguinst which the vines an be trained, and, like all lean-to houses, it is cheally constructed and heated. The three-quarter span homses are also excellent for either foreing or cold graneries, but unless one has walls that can be used for this purpose it will be preferable to build span roof houses ruming

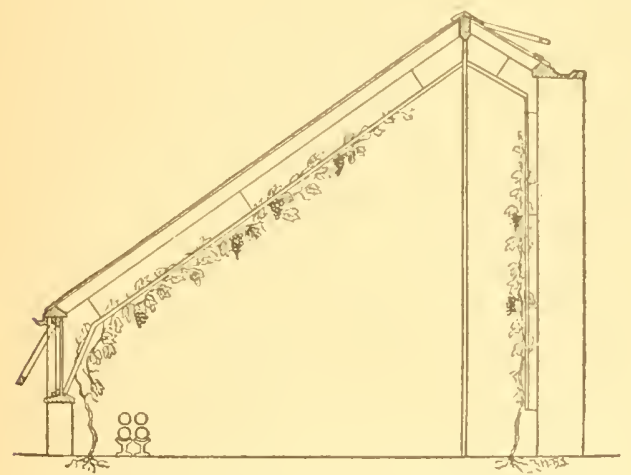

FIG. 9\% FORCLNG (iRAPElit (Section).

north and sonth, exeept when grapes are to be forcer in the winter. The span roof luonse, Fig. 98, cheluses a larger body of air than either of the other homses, and it will be easier to regulate the temperature and the moisture in sneh a house than in a narrow one. In addition to the above reason the wille louses are preferable, as they have longer rafters and afford more space for training the rines.

The enrvilinear roof is freqnently used for vineries, and in Fig. 99 is shown al section of a curvilinear house. Thes give somewhat longer rafter's for training the sinces, but they have no other alvantage, exeept, perhans, in 
appearance. and this will not comnterbalance the increased cost.

The even span greenhouses, with straight sash" bars, seem to be the farorite form for graperies. In their general construction they do not differ from even span structures of similar dimensions nsed for other purposes, and for the details of construction reference is made to Chapters V and VI. There are, however, certain points that shonld be considered in erecting a grapery. If the

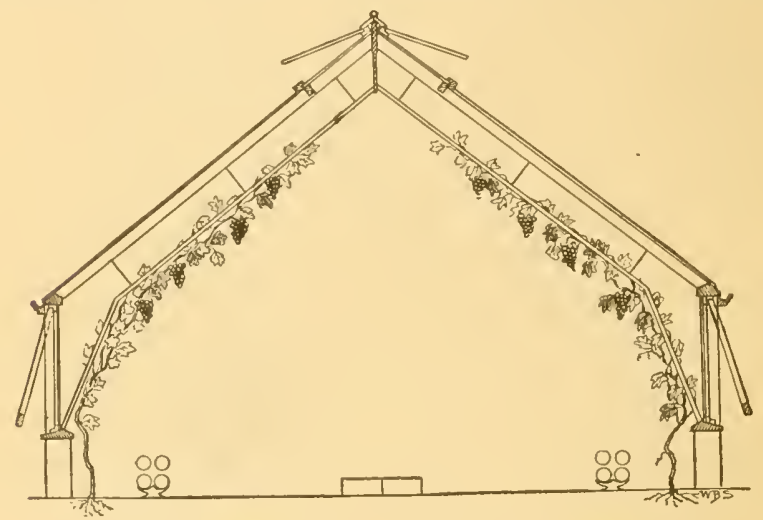

Fifr. 98. ETEN SPAN GRAPERT (Section).

honse is a wide one, the slope of the roof may be less than if it is comparatively narrow, and thirty-five, or even thirty degrees pitch will be sufficient in one case. while forty, or perhaps forty-five degrees, may be desirable in another.

In choosing a site for a grapery, it is well to have it somewhat sheltered from the north and east, and, by all means, it shonld be well drained to the depth of three feet, that the border may not become wet. The situation should be such that it will not be affected either by the shade, or the roots of large trees, which might get into the border and steal from the rines. 
I'he wall of brick of stone, if eillere he msinl, should extend for a foot or so above the level, and it a purtion of the border is to be on eitch sile of the wall, alleher-

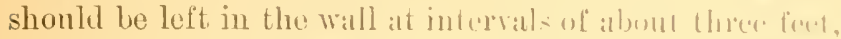
with openings at least one foot sefualle throngh which the roots ean make their waly. Upon this wall Hhere shoulel be one of woorl two foet high, with antinnoms side rentilation (sec Fig. 9s). If it is clesired fo malhe the first cost as low as possible, the sile walls may le bujlt of wool, withont the nso ol a stome fonmdalion, but in the damp borter it will not he rery durible, and the form of wall deseriber alowe is proferahle. The root

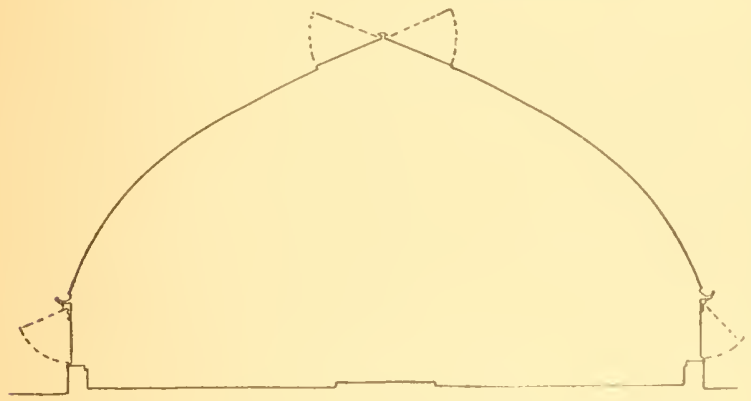

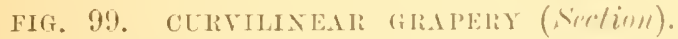

should be somewhat stiffer than for an orelinary erreenhonse, but it need not be different in eonsturetion from those described in ('hapter I'I. 'T'here shomlel he. at least, one line of rentilation at the riglese, and proferally two in a wille holse.

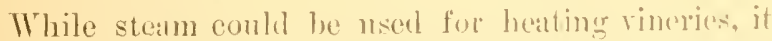
has not to any extent, hot water hemer relied on for the most part. The the is not sat isfiletory and is but little used. In arranging the pipes. it is best to ladte them three or four feet from the vines, as if in a dose provimits, they might unduly aly ont the border, and womli] tend to invite the development of the red spicler. 'I'he 
radiation should be ample, and so smpplied with valves that the amount of heat furnished can be regulated at pleasure.

Some arrangement should be made for training the vines, and perhaps the simplest form of trellis will be made of No. 12 galvanized wires, arranged one foot apart, and suspended about fifteen inches below the sash bars (Figs. 97 and 98).

\section{ORCIIARD HOUSES.}

1 many sections of the country some of omr choicest fruits, snch as peaches, nectarines, apricots, sweet cherries, etc., camnot be grown in the open air, and if their cultivation is attempted it must be under glass. In Enrope fruit honses are very common, and for many years have formed an important part of the greenhonses, not only upon the large estates, but in conneetion with the cottages of the middle classes. On this sicle of the $\Lambda$ tlantic, the ease with which these crops ean be grown in fivorable loealities, and the abnndance and cheapness of the sub-tropieal fruits from Florida and Califormia, have united to restrict the use of orehard homses. While it is donbtful if they can be made profitable as commercial ventures, except under unusually favorable conditions, many persons find them very desilable to furnish a supply of fresh fruit ont of season for their own tables.

In their construetion, orehard houses do not greatly differ from graperies. The walls are built in the same mamner, but shonhl have a height of six feet, at least one-half of which should be of glass. They may be constructed of wood or iron posts and boards np to a height of two feet, or they may have a masonry fommation with a brick wall above. The glass in the side walls should be fiom three to four feet high, and at least onehalf of it should be in the form of ventilators, hinged at 
the top. The roof may be cither of morable sash or of fixed sash bars, the latter lneing preforable if the homse is to be a permanent one. In this calse imon pusts, lailters, purlins and ridge, with rypuess sash balls, wan he used to alvantage. With the high walls, to ritu roum for the trees at the sides of tho honses, it will be desixable, particularly if the house is a wire one, to give the roof a comparatively low pitch, in orter to bring the glass down as near as prossible to the plants in the eontel of the house. I slope of twenty-six degrees will all-wer, and if the house is more that twonty-five foret wille, twenty degrees will be preferable. Ample means of rentilating the houses should le provided. In amblition to the row muder the plitte, there should be one, in nirrrow houses, and two in wille ones, at the ridge, and door's or ventilators in the ends are also derirable.

While any form of homse, lean-to, eren span, or three-quarter span, curvilinear' or straight, may he nsed, the wide even span will be most satistactory, as the light will be more evenly disibuted than in either of the other forms, and the temperature and moisture will be easier to regulate than in a lean-to or in a narrow house. While houses not orer twelve or fiften fect wide will grive fair results, a width of eighteen, twenty, or, better yet, trenty-fire feet will be preferable. The lean-to will be a cheap form to elect, when it an be built against the sonth wall of a building, but when this cannot be done, an even span house will cost no more, and will be much more satisfactory. With a lean-to construction, a honse about fifteen feet wide can be built when the sonth wall is five or six feet ligh and the north one fourteen or tilteen feet. While not really desirable, a martow lean-tn house six to ten feet wide "all he used. 'T'he (o) tion would be about the simne als that of a nallow lean-lo grapery. In this kind of a house the trees are gencrally trained upon the north wall. With proper cille in reg- 
11 lating the heat and moisture, and in ventilating, fair results will be obtained. If to be used as fruit-forcing houses, the three-quarter span house, with the long slope either to the north or to the south, can also be used.

While some growers plant the trees in the border, others grow them in pots or boses, and are then able to pack the trees away, and use the house for other purposes until it is necessary to start the trees in the winter or spring. In natrow houses there is only one walk, the trees being arranged npon either side, bnt in wide span roof houses, although this arrangement is often made, it is preferable to have two walks, one on either side, abont four feet from the walls, thus securing the peak of the roof as an allitional sprace for tall trees. When there is a walk in the eenter of houses orer fifteen feet wide, it is necessary to have a narrow walk upon either side, for conrenience in watering and earing for the plants.

\section{FIRE IIEAT.}

Even when ouly used as growing louses, it is desirable to have the lrouses provided with heating apparatus. While dormant it frequently happens that the temperature may drop so low that the buds will be injured, sinee, ats a rule, the buds are not as well ripened as when grown in the open air, and will be more susceptible to cold. It is after the buds start, however, that the danger of injury by cold is greatest, as, if the temperature falls below the freezing point while the trees are in bloom, the erop, will be lost and the trees greatly injured.

Althongh steam or hot air flues may be used for heating, lot water will be found more satisfactory. The piping shoukd be sufficient to keep the tenfperature of the house at forty-five degrees in the coldest weather that is likely to oceur after the trees are started. If peaches or other fruits are to be forced, they should be 
started as soon als Mancele 1 , and the foreing maly (rommence as early as Jantairy. In the forcind hotise at lentperature as ligh ats fifty of fifty-five derreses at night is necessitry for the best results, and in estimtating the radtiation this should be kept in mind.

\section{CHAP'TER IXVHI.}

THE IRRANGLMENT OF GHEENHOLSES.

When a large number of houses that are user for different purposes are to he (ombined, considerable shill is necessary in order to secure the best results. The arrangement depends largely upon the kind of hensis, as well as their size and shaje, and as there are, at loast, ten or a dozen houses that go to make up a commplete plant, in the very oclection of the houses for the establishment there would he opportunity for limulreds, and even thonsinds, of combinations. Wre have outlincer above the struetural peculiarities of seren or eight of the more important houses, and have alsowhore deseribert the rose house, propargating honse, forcing house, cte. and now offer for consideration perspective riens and ground plans of greenhouse establishments, designed by the leading horticultural arehitects and builders of the country.

The first illustration, Fig. 100, shows a liart of the greenlionses at the Michigran Inricultural Collecre, and in Fig. 101 a gromud plan of the honses is shomm. This range of houses is not an clathorate one, but it is wall arranged, and in connection with a grapery and two forcing houses makex a fairly complete establi-hment.

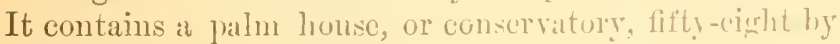
twenty-fire feet, a stove room twonty-fire ficet syluarce, 


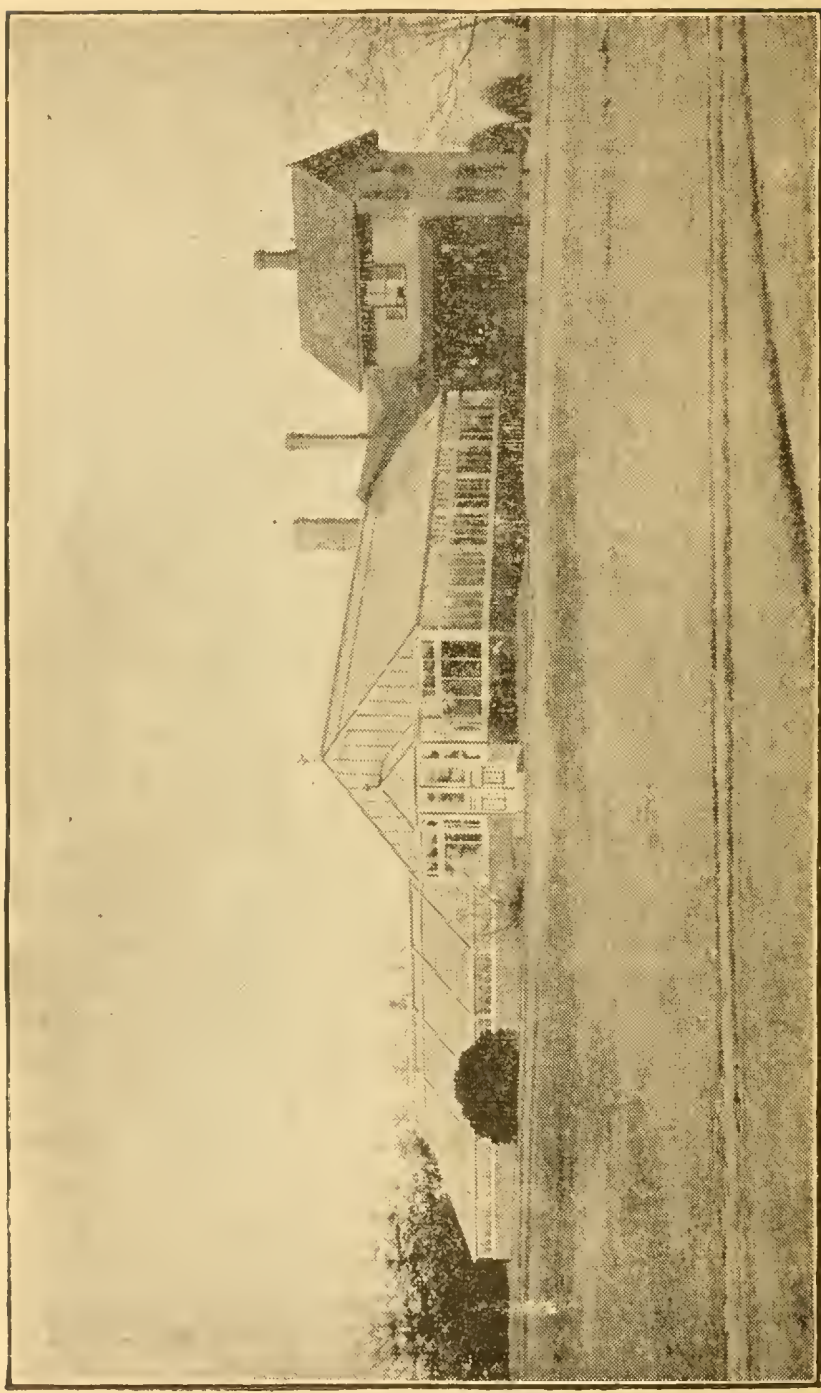

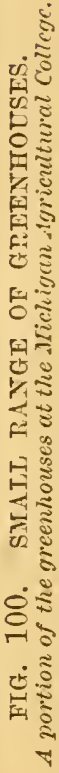


a cool honse of the same size, al rose room cirthtern lyy twenty-fire feet, two propagating (lut and cold) homses for the glowing of bolding plants, aach twelne by fifty feet, and another room twenty-five ly twenty-foul fret. that is nsed as oceasion demands. "Thle worklosm is twenty-five by fifteen feet, and is orel the leaters. 'T'he gardener's honse, ats shown in the illustration, is juincel to the comservatory.

The houses shown in perspective wore areeced in 189:, by Lord it Burnham ('o., and are of their irm

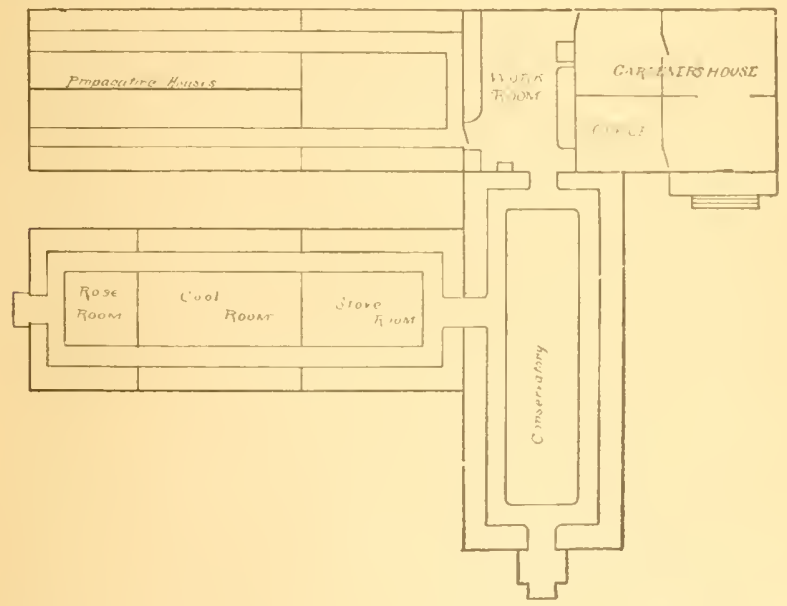

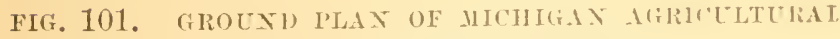
COLLEGE GRENHOLSES.

frame construction, with all outside work of cypres. The walks are of cement, the talbles of ande imon with gas pipe legs, and with slate tops in some ronms and tile in others. The howses are heated hy a No. s Furman hot water heater, put in by the IIerenclecu Mannfiretmring Co.. of Geneta, N. Y. 'The mothu I uf cumstrumetiun the walls, roof, benches, and the heating coils is shown 


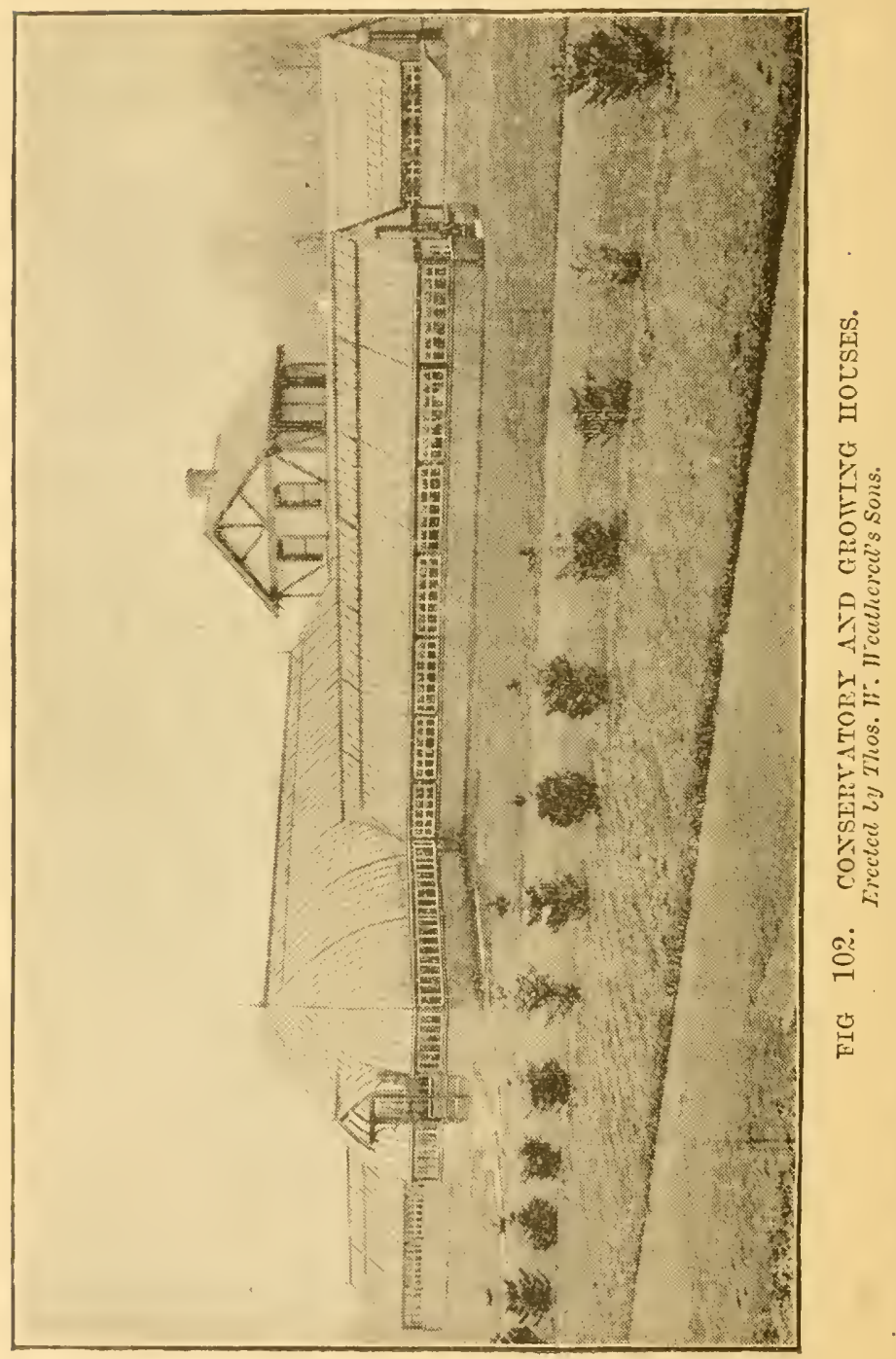




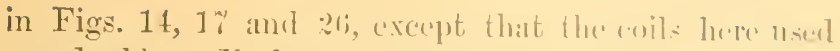

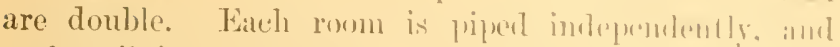

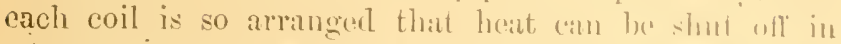
whole or in part from one renm withont atlerefing the others. In the rear of the now erenembenses als shem in the groumd plan, are three other honses, hlat were erecterl some fifteen years ago. 'They ane entimly (口) structer of wool, and although kept well paintid, are showing signs of decay in some places. 'T'hey alle heatrel by a spence lot water heater, and the ranliatiug surfare? is supplied by two-inch flow pipes and one amel onc-half inch returns.

Similar in construction, in many reperts, to the new greenhouses described above, are those shown in Fig. 10\%. The principal difference is in the form of tho roof of the conservatory. Which is cmrvilineale and in the arrangement of the growing honses. This ranger was erected by Thos. II. Wratherel's sons, at New 1)orp, Staten Island.

A larger and more expensive range of homses is shown in Fig. 103. The gromud plan of these housen is illustrated in Fig. 104, am! from this the size and uses of the different rooms cam be rseretainet. The expense uf such a range of honses. romplete with irom tilbles amel heating apparatus. will unt be far from sif.um. 'I'hey were erected by Hitchings d ('o., of Xew Jork ('ily. The range, as wili he secn, (o)nsists of an elongaterl heragonal palm house with a emrilinear rool. "Thu sirle walls are quite high. and, with the pitch of the rouf. affords room for growing quite larese julants. From calch side of the conservatory, faroug calst and west. istumb two span roof growing homses, which can he meerl for stove house, cool store, and hot and (4)hel propmating houses, of houses for calmations ame other flomerimer plants. At the end of the north honses will he seru at long three-quarter span lose homse and a linge work- 


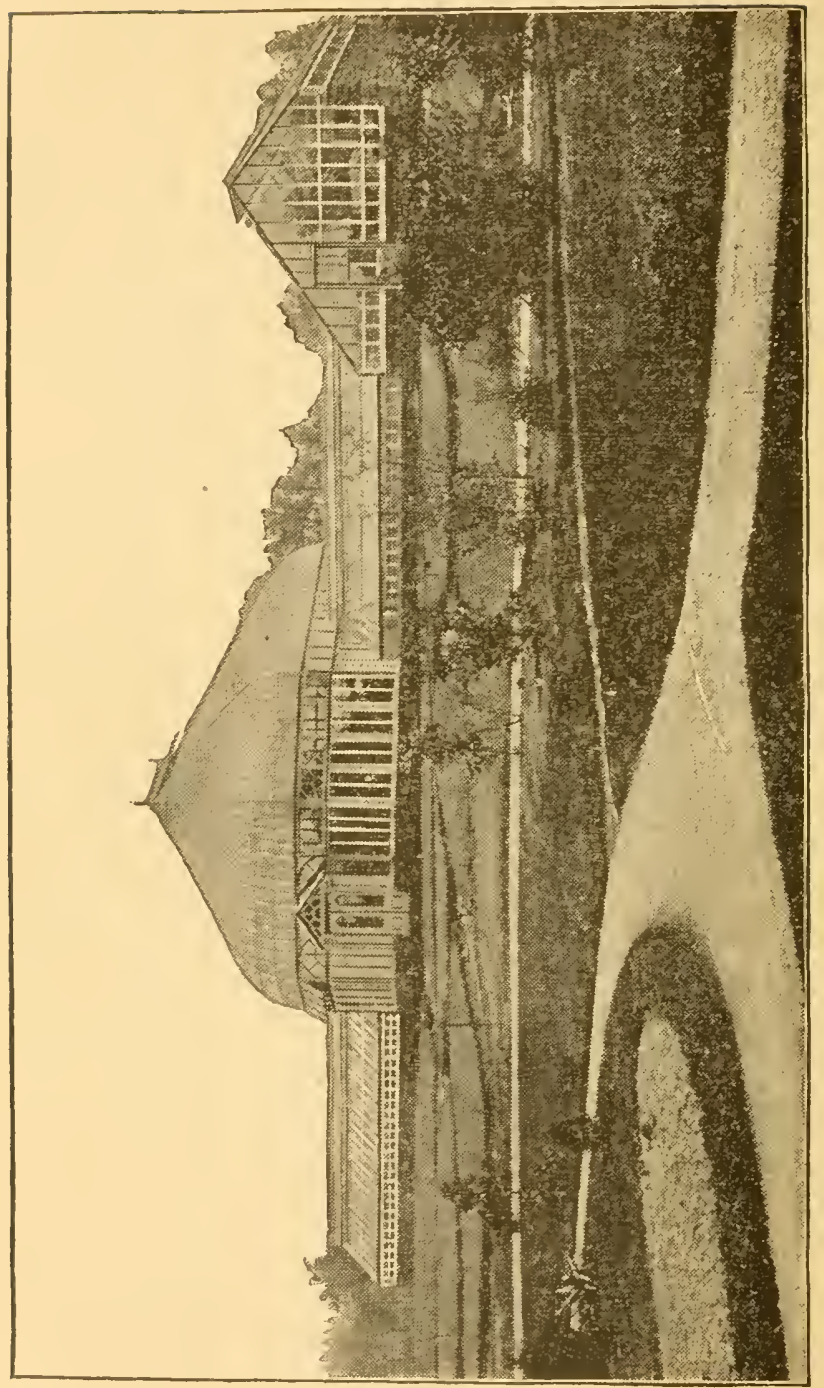

20

F

告

'́3

of

ह

F

韯

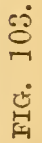




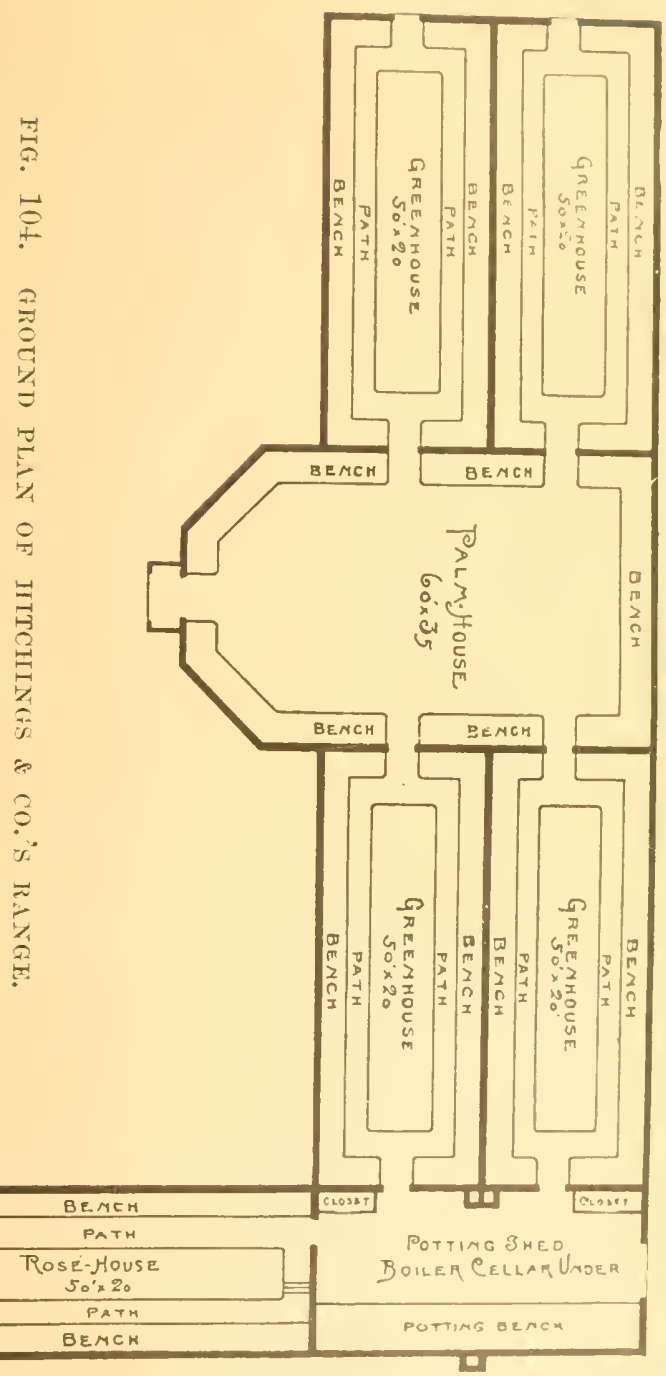




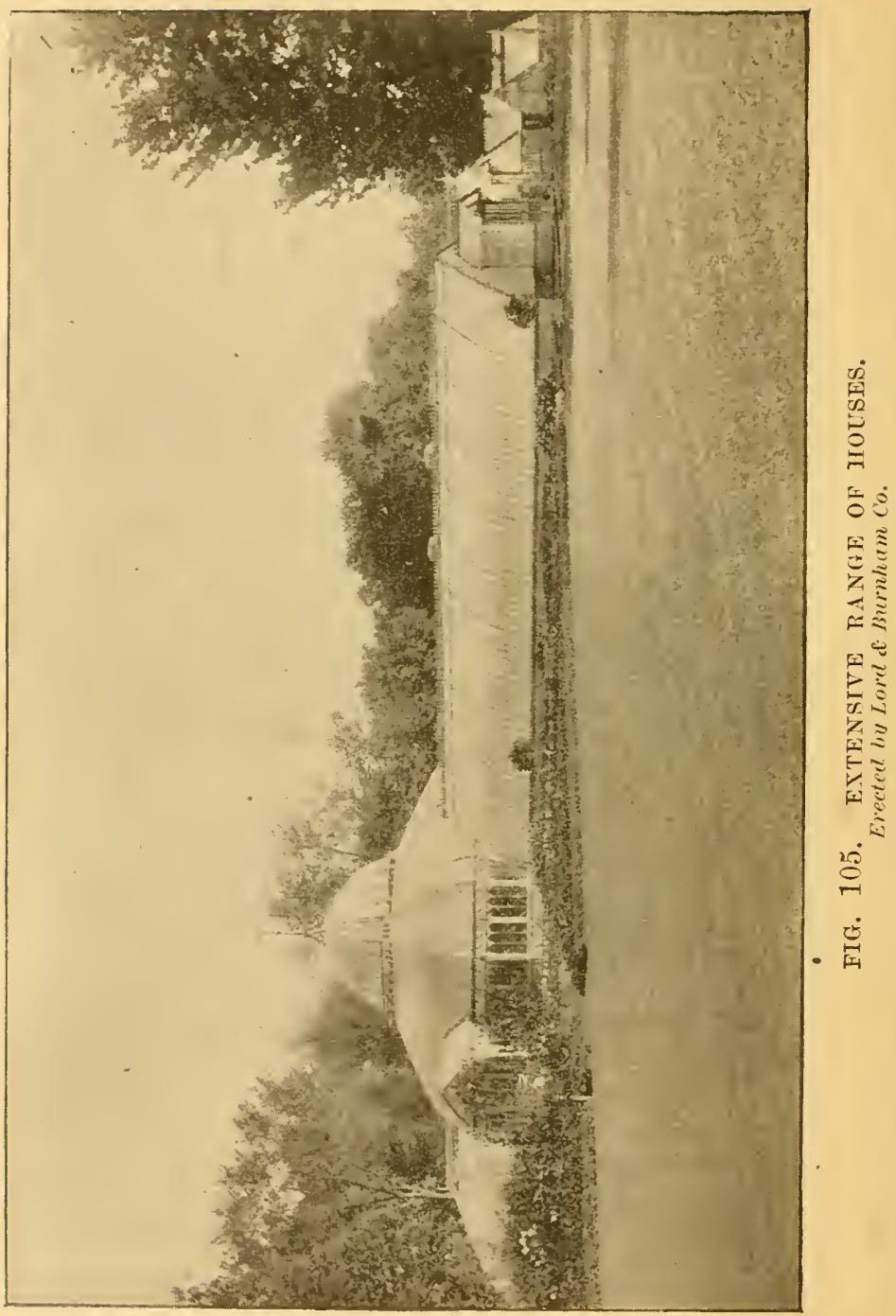


room. The method of construedion nserl by llitohings d Co. is not particularly different from the one used by Lord \& Burnlam ('o., the principal diflerence lyeing that the former generally make the raflices amel posts in separate pieres, which are elamplol together hy in imm bracket at the flate, and use iron guthers and rave

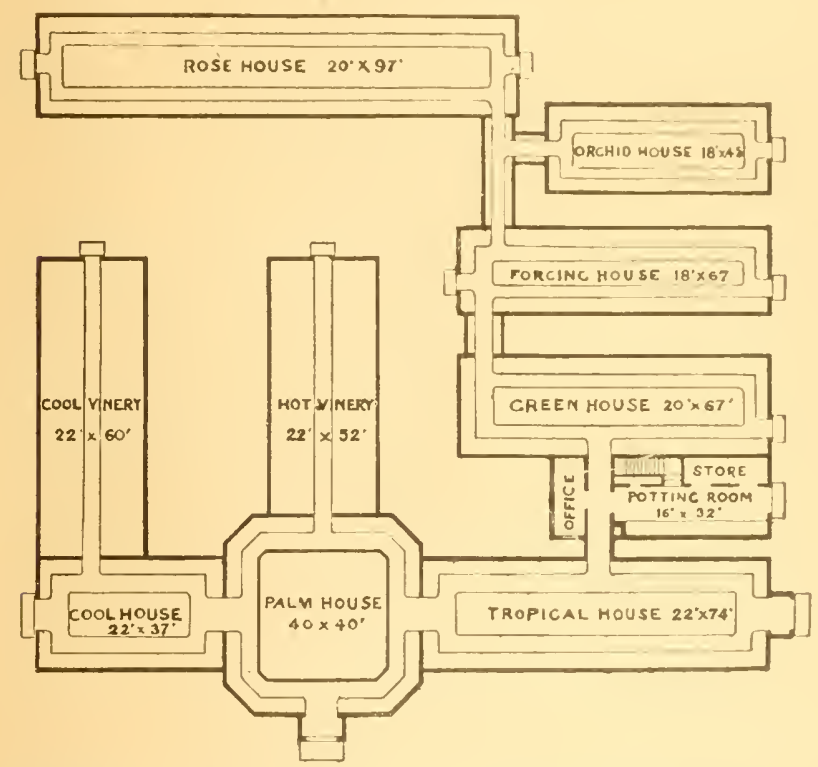

FIG. 106. GROUND PLAY OF LORD \& BURYIIII (o). R.INGE.

troughs, while the latter use wooden gutters, and forece the posts and rafters from one pioce.

If ansthing more claborate is desirest, it sill lu found in the range shown in Fig. 105, the cround plan of which can be seen in Fig. 10x. It wits desigmel

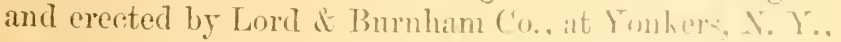
and, as will be seen from the illustratious, cursists of an 
octagonal currilinear conservatory forty ly forty feet, which is shown in cross section in Fig. 91; a stove or tropical house, with a curvilinear roof, twenty-two by serenty-four feet, Fig. 94: a cool house twenty-two by

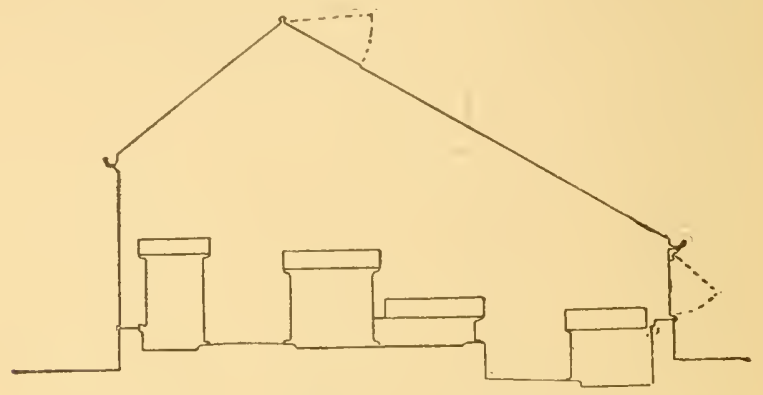

FIG. 10\% FORCING HOUSE (Section).

thirty-seven feet, also curvilinear; a span roof greenhomse twenty by sixty-seren feet; a foreing homse, with a three-ruarter span roof, eighteen by sixty-seven feet,

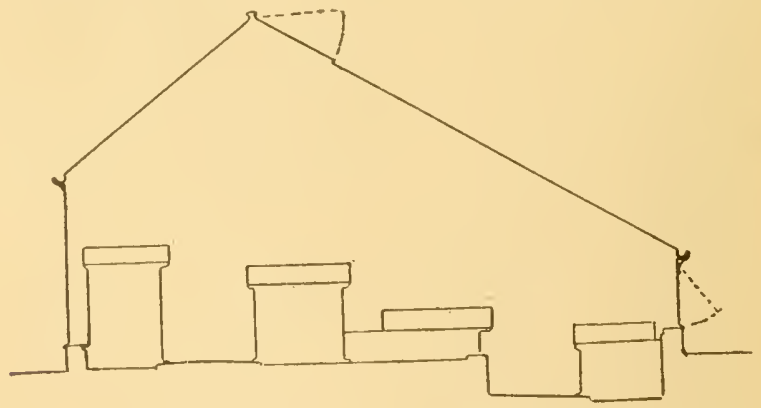

FIG. 10S. ROSE HOUSE (S'ection).

Fig. 10\%; an even span orchid house, Fig. 96, eighteen by forty-five feet; a three-quarter span rose house, Fig. 108, twenty by ninety-sercn feet; a cool vinery, Fig. 99, twenty-two by sixty feet, and a hot vinery, both curvi- 
linear, twenty-two by fifty-two tect, besides a patting room and oflice.

This establislment is very complete, and sorms in be well arranged. If plain cmrvilinear hollows atro 1lasired, the forms shown here larre been thorougrhly festerl, and lave been formel yuite satisfatetory.

\section{CIIAP'TER XIIX.}

GLASS STRUCTURES FOR MAATEURS.

Many lovers of gardening, who are restrained from indulging in their farorite pastime by oul long six months of winter, would gladly erect small glass structures in which to prosecute many of the lighter operations of gardening, but are deterred by what they imagine to be the excessive cost. In this chapter an attempt will be made to outline methods of constructing several forms of small greenhouses that can be cheaply erecterl, and which will be found very useful and entirely satisfactory. Upon many town, as well as country places, we often find suall cold frames, or cold pits. in which half hardy plants can be storel throngh the winter, and in which many of the harelier regetable and bucleling plants can be started and grown. At best, they are of little value in forwarding plants luring the sercre prarts of the winter, and are fal from satisfactory in every way.

For our present purpose al homse is meded, perhaph ten by fifteen feet in areal, comrenient to wr altarhed to the dwelling, that can be attended to in all wathers withont exposure, and that can he cheaply anstructerl and maintained.

\section{ATTACHED COFSERT ITORTES:}

It is frequently desirable to have, in emmortion with the dwelling, a room conclused with grlass, in which 
flowers can be grown or exhibited. The large structures that are sometimes scen do not differ, in their principal features, from detachel conservatories, and need no consideration here. Althongh the best results, so far as the growth of the plants is concerned, eannot be obtained in a lean-to structure, the fact that small conservatories can he placed in an angle of the dwelling, where the walls of the house will form the end and rear of the con-

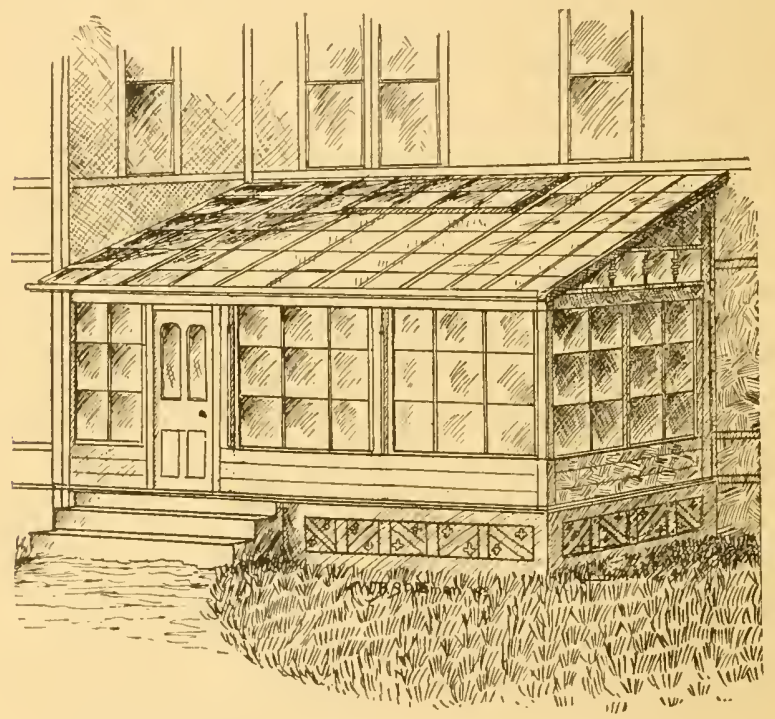

FIF. 109. VERANJA CONSERVATORY.

servatory, and thus greatly rednce the cost of construetion, leads to their nse when the first ontlay is considered. These attached conservatories, in the lean-to style, may vary in width from six to fifteen feet, but if anything wider than this is desired, it will be best to liave detached honses, or to use some other form of roof.

The simplest kind of a conservatory of this style is made from an ordinary veranda, in which the spaces 


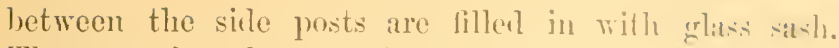
These can be taken out in the smmmer, if devirol, and the rerandit restored to its orlinitry usc. By the atdlition of a glases roof, far better results can be oftained, howerer, and if a veramlal eonservatory is (1) be built, it will be found cheaper than a wooden or a tin roof. It shonk be eight or nine feet wide, to secure the best results, although il verandil five feet wide will answer as a conservatory.

In constructing these reranda conserviltories, Fig. 109, at locttion on the sonth sicle of the house should be selected, as a rule, illthongh for ferns and similar plints, the eist, or even the north sisle is preferable.

'T he frimework of the conservatory should be put "1p in a permanent matlner, as should the entire roof, but it will he sonetimes found best, if the glass in the side

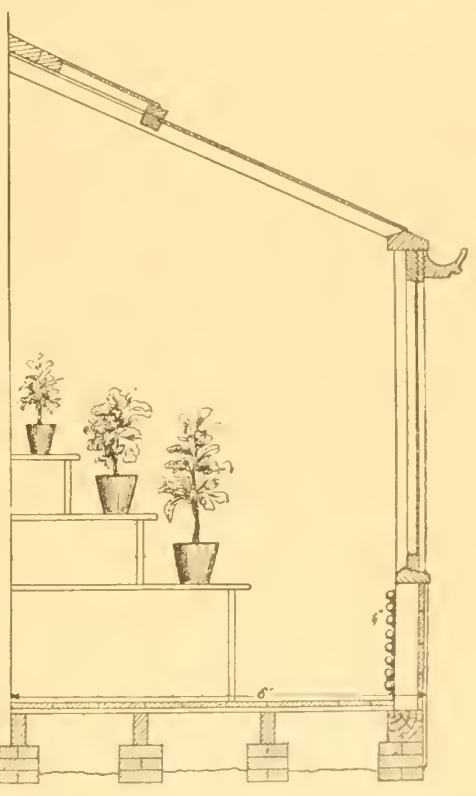

FIG. 110. VERIND.I ('ONSERVATORY (Fertion). and ends is of temporary sishers, so arrangerl that ther can be taken out, as seen in cross section. Fig. 110. Thic' floor shonld be at the same height, and construtedel in the same manner at fol an ordinary reranda, although at cement floor may be nsed if desired. In cals a wourlen floor is used, the verindia should be closerl in bolow, of ceiled against the floor joists. 
If designed as a conservatory for flowers, a doorway in the wall of the dwelling should be arranged in the middle, either of the side or end, and in ease the conservatory is a large one, it will be convenient to have an onter door. As a rule, these doors should be opposite each other. It is also an excellent plan to have the portion of the wall of the house adjoining the conservatory, of glass. The posts should be from five to seven feet high, and placed five feet six inches apart. At the height of two feet a sash sill should be placed, and the space beneath shonld be filled in to correspond with the finish of the house. The walls of the reranda above this sill may be of permanent sash bars and glass, or, as is better, unless it is to be used as a conservatory thronghont the year, the spaces between the posts may be filled in with glass sash that can be taken out dnring the simmer.

If a verunda is made eight feet high at the eares, this will admit of the placing of a rentilating sash in the front wall, but in low structures it will have to be placed in the roof. The conservatory roof should have rafters of two by four inch cypress rumning from each post to the wall of the bunse. The remaining framework of the roof will consist of two by one and oneeighth inch sash bars. In Fig. 110 is shown a cross section of a house six feet wide, from which the details for the construction of the walls and roof can be ascertained, while Fig. 109 gives an idea of the exterior appearance of the same conscrvatory.

If the :momnt of glass exposed is not too large, neeessary lieat can be supplied from the adjoining living room for so-called cool house plants, but it will be desirable to have heat directly supplied to the room. Hot water or steam heating pipes, arranged as in Fig. 110, will be desirable, but if nothing letter is available, one or two large kerosene heating stoves can be used, pro- 


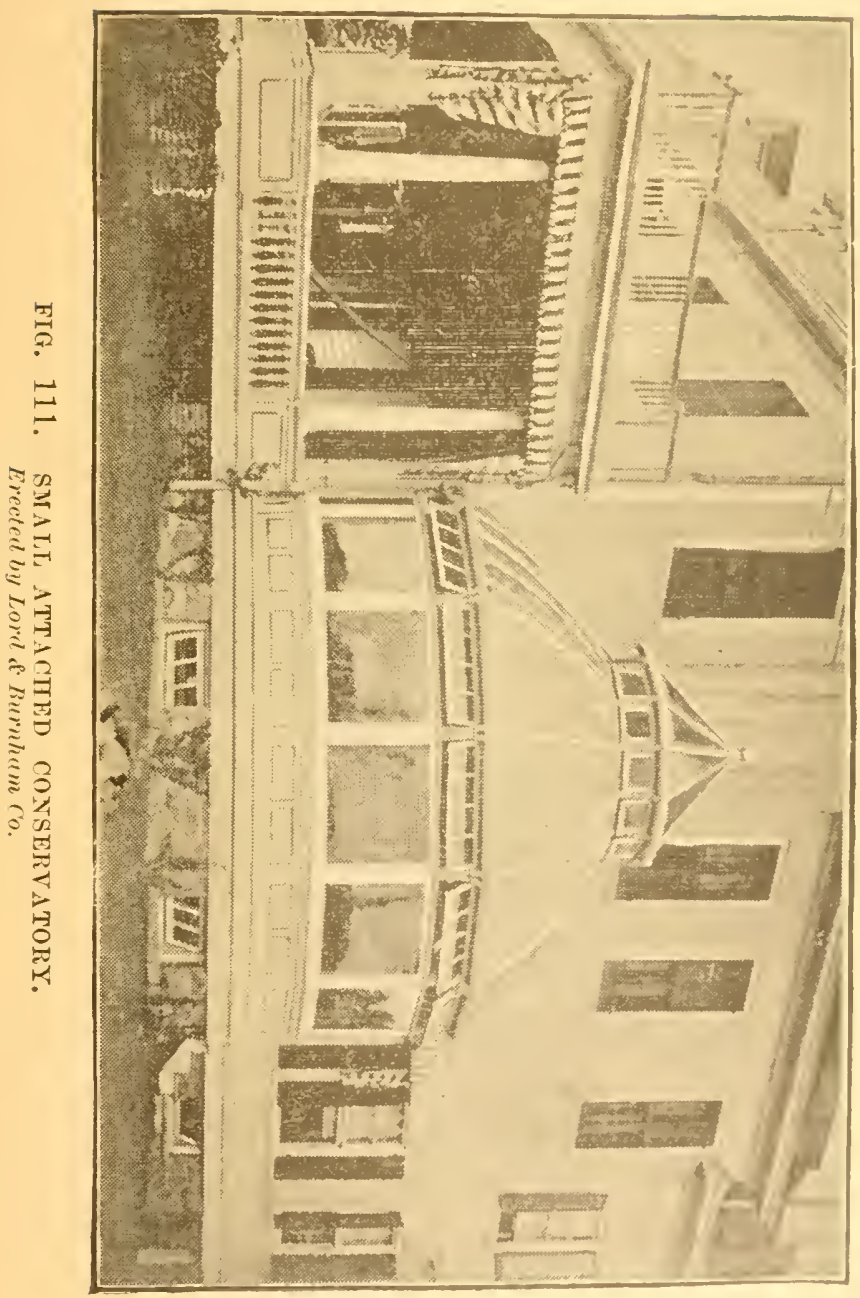


vided pipes are arranged to carry off the gases of combustion.

If more elaborate structures are desired, they should be of a style that will correspond with that of the residence. The location at the colner of the house, as seen in Fig. 111, is desirable, as light can lie obtained from three sides, and better results can be obtained than in a rerandia conservatory.

\section{DETACHED FREENHOUSES FOR AMATEURS.}

It frequently happens that for some reason it is not desirable to have the conservatory attached to a building, in which case there will be a great variety of structures from which to select. Ifere, again, the lean-to form

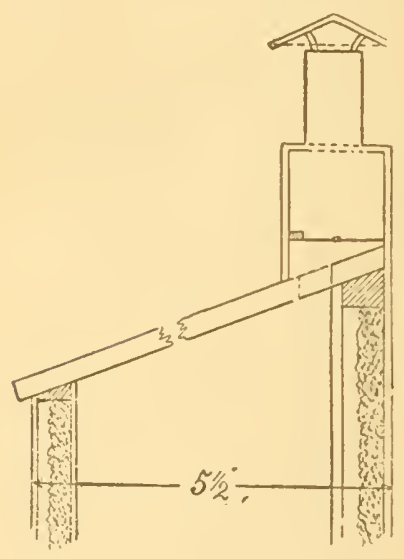

FIG. 112. A CIELP HOUSE (Section). will be found a cheap one to erect, and the same directions apply here as in a large house. In Fig. 112 is presented a cross section of a lonse built by Chas. Barmard, and described in the Ameriran Giarlen, October, 1890.- The walls were built as shown in the engraving, sheathed on both sides, and with a layer of hair felt inside. A cheaper wall could be erected by double boarding the ontside, and having a layer of heary building paper between the boards. The outside boarding of the north wall cxtends one foot abore the roof, to act as a wind-break. The walls measure five feet six inches outside, and the roof is formed of hotbed sash, the juints being made tight with battens. Tentilation is secured through a cupola in the center of the ridge. 
The base of this is twelve inches square, and the circulation of air is controlled by a dimper, ats will be seen from the engraving. If other forms of honses are desired, they will only be miniatures of the large ones described in previons chapters.

\section{PORTABLE CONSERTATORIES.}

Sereral builders make a specialty of supplying houses of the kind. Fig. 113 shors one of these houses put up by Hitchings \& Co, and in Fig. 114 is seen the same house with a portion of the sash remored. As will be seen, the honses are bnilt with an iron frame, sinilar to that used in lirge honses. and corered with sash that ean be rery pnickly put in place. They are supplied with hot water heating apparatus, and rentilating machinery. Besides being portable, the homses are extensible, and another section can be added with little trouble at any time. A louse eight by sixteen feet, with heating and rentilating a]plaratus, costs abont $\$ 360$. It makes a very durable honse, and is, in every way, first cliss.

If one camnot ifford so expensive a homse, al very satisfictory conservatory can be built by using four by four inch posts for the walls, set four feet apart, and with every other post four feet high, the others being cut off at the height of two and one-half feet; sash, sills, plates. end rafters and ridge pieces can be obtained, eut in the desired shipes, at any wood-working finctory, or from dealer's in greenhouse materials. The roof may be mate of fixed sash batrs or of tempolary sash.

The heating apparatus for a narrow honse will cost from four to five dollars per linear foot, and the rentilating apparatus from ten to fifty cents, according to the kind used. 'The lmmber can be estimated at about $\$ 3.00$ per linear foot, and the glass will not be far from $\$ 1.50$ per foot, while the labor of uarpenter's and painters will 


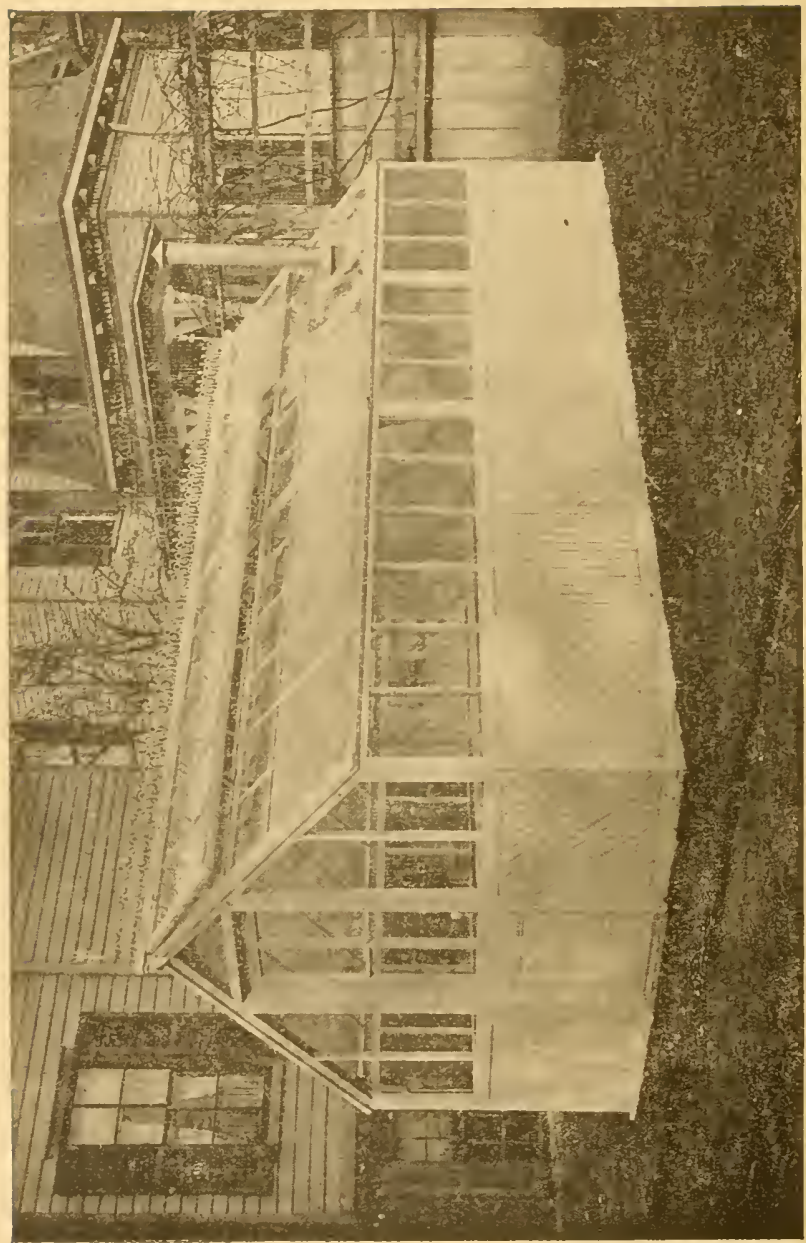

㢳

ت 


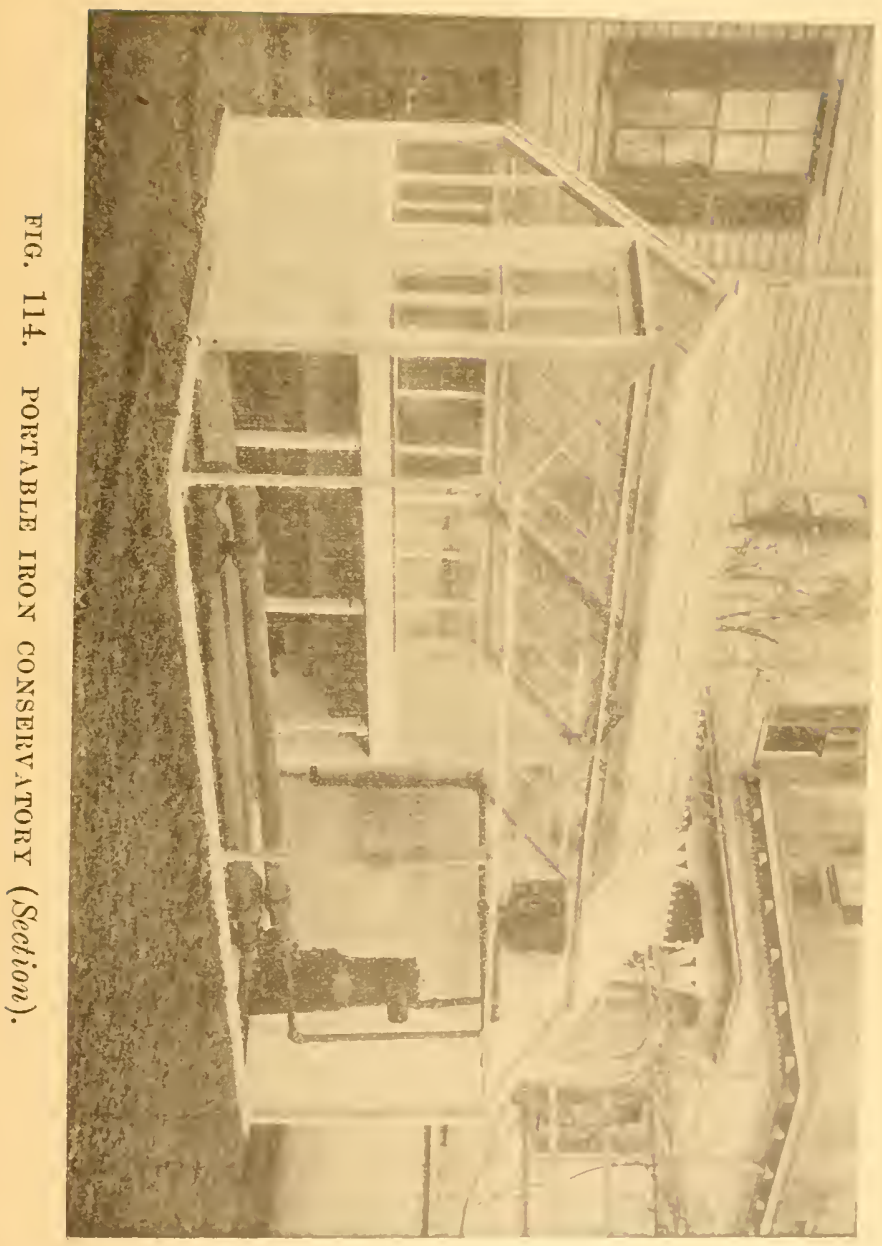


be about $\$ 2.50$ per foot, or a total of $\$ 225$ to $\$ 250$ for a substantial honse fifteen by twenty feet, with heating apparatus and benches.

\section{THE BASEMENT PIT.}

There are some objections to the structure to which the above name has been given, the principal ones being that it is somewhat rifficult of access, that it is inconspicuous, and that the plants grown there do not give the pleasure they would, were it entirely above ground

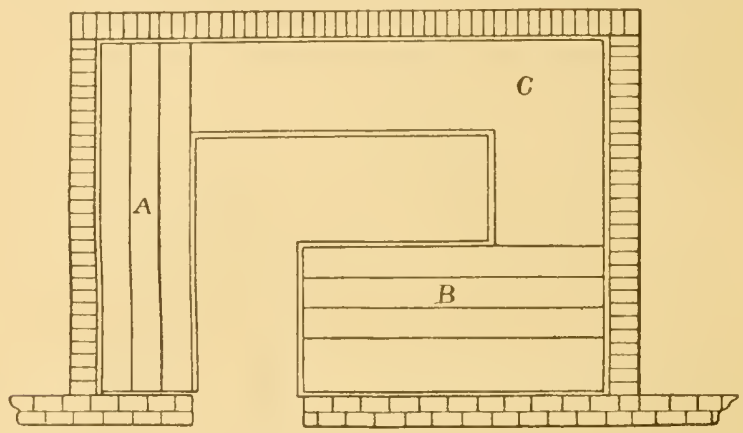

FIG. 115. GHOUND PLAN OF BASEHENT PIT.

and separated from one of the living rooms by a glass partition. The points claimer for the basement pit are, that it is very easily heatel, owing to the comparatively small area of exposed glass, and its cheapness of construction, and every one of the objections urged against it conld be overeome by raising the structure to the ground level and supplying the needed glass partition and door.

For the location, it is best to sclcet the sonth side of the dwelling, if possible, although the west, or east, or a point between would answer. If it can be situated where a cellar window is located, all the better. 'The wall is torn away so as to aflord an opening three feet 


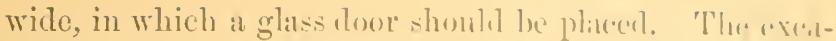
vation is then made, and the wall of masmm latil mp

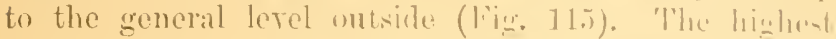

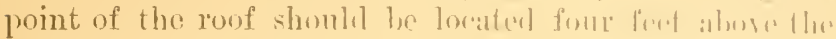

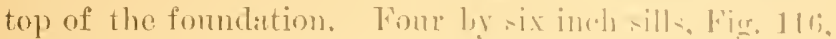
(a) should then he put down, and mpen these fonr liy four inch posts (b) twenty inchus light, and with rabluts for glass, shomld be placert at the corruers and at interTals of five feet along the side and ends. The two by five inch plate is then placed, as seen at $(c)$, and a four by two inch fascia $(d)$ should be set into the tops of the pusts along the front, and two by four inch rafters (f) should extend fiom the top of the posts to the wall of the hons? where they should be supported by a fomr by one incli riclge board. A gutter (o), if desired, will complete the exterior of the structure, with the exception of the sals bars, purlins, rentilators, and gratz.

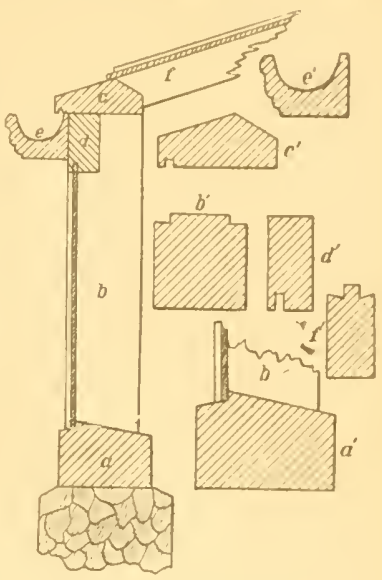
ing, which will not differ from the same parts of a greenhonse. The interion arrangement will repend mon the nes to which it is to he put. 'T'he doolwar may be in

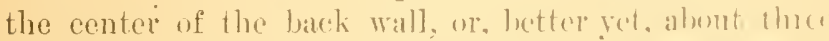
and one-half feet from the cast end. if clesined. a flat table $(C)$ three feet wirle. for slatrting cuttings and soretlings, and for the growing of vergotalse and herldiug plants. cam extend aloug the wert and sonth vildes, and

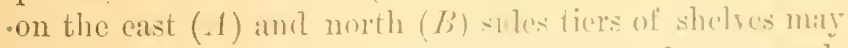
be placed, on which the latrere plants can ho artangerl. The amount of heat Jerguinecl for sisch al homser will 
depend consiterably upon the kinds of plants to be grown, as for many greenhouse plants a temperature of forty-five to fifty degrees is ample at night, and if it occasionally drops below forty degrees 110 harm will be done, while most of the so-ealled store plants would be injured if the temperature reminins below sixty degrees for any length of time. If the pit npens into a large cellar, particularly if it contains a hot air furnace, or other heating apparatus, there will be little danger of frost, except in severe cold wcather, when an oil stove placed in the room will be all that is necessary. For

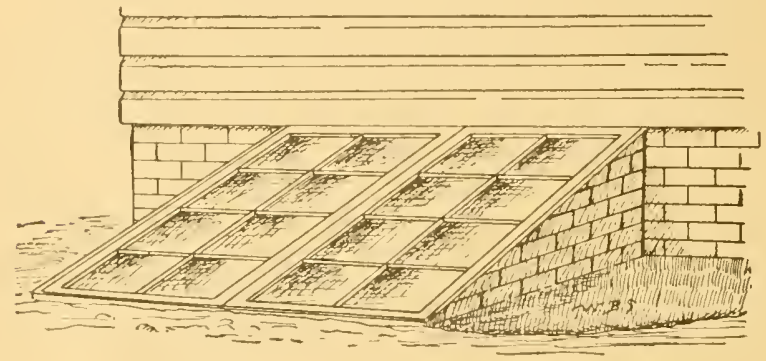

FIF. 11\%. CELLAR-WAT CONSERTATORY (Perspective). stove plants, the use of a second stove in severe weather would probably be required. If the dwelling is heated by hot water or steam, of course the matter of heating would be very simple, and, if not, the next most satisfactory plan will be to nse a small hot water heater, or to obtain heat by placing a coil in a lot air furnace and connecting it with hot water heating pipes in the conservatory. Directions for arranging the pipes, etc., will be fomnd in the chapter on Heating Greenhouses.

Where only a small cold frame or hot bed is wanted, it can be arranged just outside a cellar window. If a frame four by two feet is sunk in the ground and covered with a hothed sash, the pit thus made can be used for 
growing quite a variety of greomhonse plant-, and for starting plants in the spring. Jnserere wath are al lishl

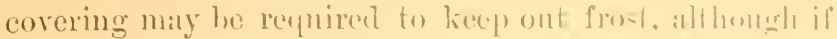

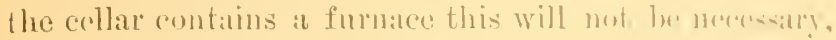

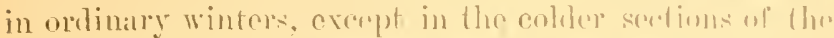

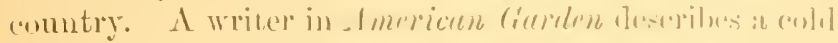

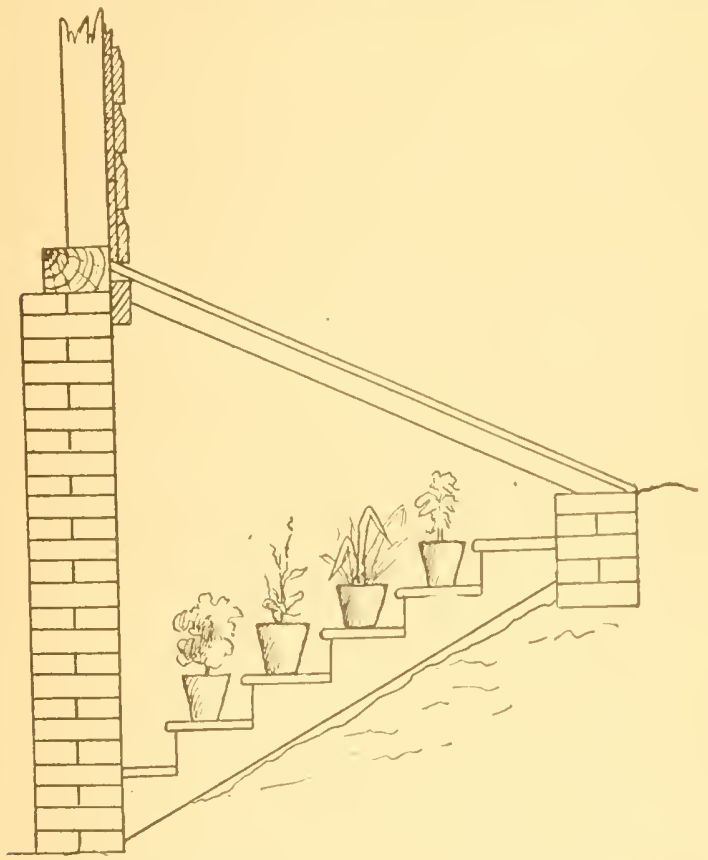

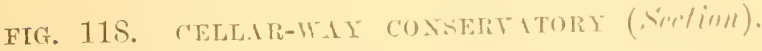

pit arranger in the outside cellith-llity of at hollec. The doors shombd be remorert and replaterel liy hothert sash, as in Fig. 11i, which thows the appeatrame of the

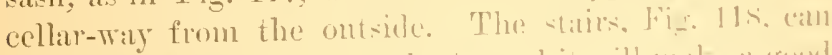
be nsed as shelves for the plants and it will malke at eromel

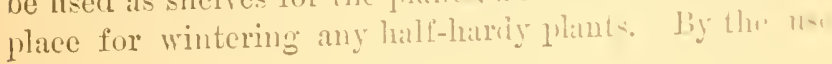


of shntters and mats the frost can be kept out, even without opening the inner doors. If artificial heat can be provided, a variety of plants can be grown.

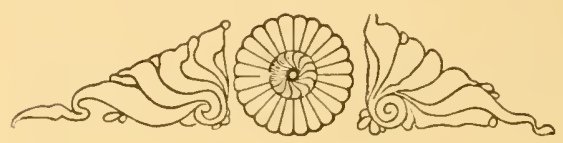




\section{N D E X .}

Amateurs, greenhouses for ... 1!5

Arratugenent of lumses.........

bitluard healer.............. 13

beneh botturus, slate ........... st

Bellel buttoms, tile..........

bencli bottoms, wooden......

Bencli frame, angle irolı...... sil

liench frane, gals pipu for..... t!

beliel frame, weolem........ ti

benclies, greenlıuse ........ ti

Boiler, size ol, 10 use......... $\{: 4 ;$

Builers, steam, and their loea. tion.................. 123

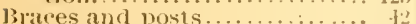

bracket brafe for root ......... 4.

Brals aut points lol glating... (i)

Brirk walls, eonstruction of.... 23i

Builhers, greenlunse........ \&

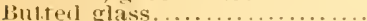

"Clnallenge" ventilating maeline

Clianras of ilreftion and level in lieating pipes........... 111

Clotap, ventilating machitue... - it

Cold frames and pis.......... 11ij

Cumbined wot and irm loumses................ 40

Commereial estahlislments... lis.

Consecliug different sistems.. IIt

Conservatories, iltarlitel...... 1!

Conservatories, inul frame.... 170

Conservat ories, jortable.......

Comservatories, small, lieating

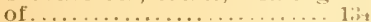

Comservaturies, nse and (9omstruftion of ............... 1ifif

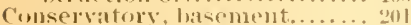

fonservatory, cellatrwal ... . . 20 20;

Continums ventilation........ fis

Cool liomses................. 1iti

Curvilinear houses........... Is

Dealers ingremhumse material 3.

Details for irou aul woul ruof 41

Details for woolen roof ........

bouble and single sirengll

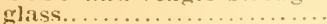

Drip gutters in sasil bars......

Evej span luouses........... t;

Fire heat fur oreliarol jousts... lxi

Fire loutbeds................. 13k

Fire surface, arrangentent of . $9:$
F Jul+al aud rouglı plate glass.. 5x

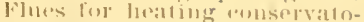
ries

Fol

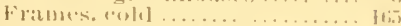

lialvani\%ed i mul sitsl l)ar 4 .... 1\%

filiss illel rlizing.............

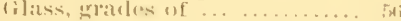

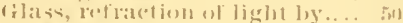

lilalss, si\%e $u f \ldots \ldots \ldots \ldots \ldots \ldots \ldots$ in

lijass, stremoll of ........... 5

filazing, m1.1 hots of ......... $5 ! 1$

filazing strip .............. this

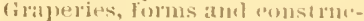
i ion ol.

lircenlublse, a clieap, lor antallemis:

Givertulutist lot

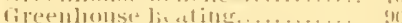

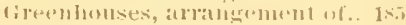

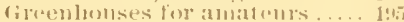

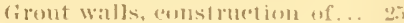

fillters, womlen............

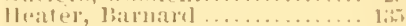

lleatre, f:urumely............ 11.

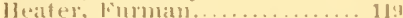

1leater. Ilitchings batio burnilly ................. 121

IIeatel, Ilitehings' enrrugated, 11ti

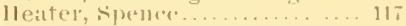

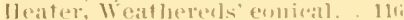

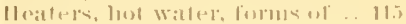

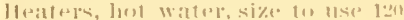

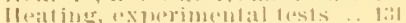

Healingr, llues for . . . . . . . . l:iti

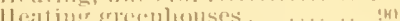

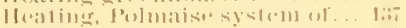

lleatiur witl lut wallur ...

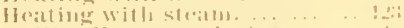

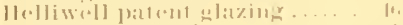

llistury ut erremlumst.s. .

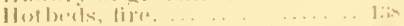

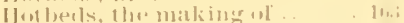

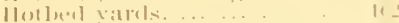

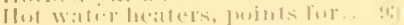

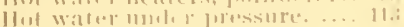

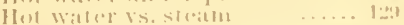

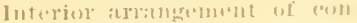

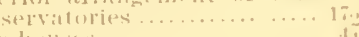

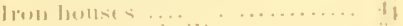

lrum pusts and sills .......... il 
Iron rafters and purlins....... 40

loun sasli bal's, galvallized .... 47

Jean-to louses.............. 12

Jeftuce liouses, romstruction of 154

Location and arrangement uf

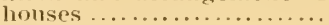

Maclinery, ventilating........

Masomly walls.............. 24

Nlats and sleuters............ 16il

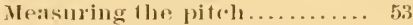

Nitrow lunses, piping for...... 110

New departure ventilating machine.

New methods of glazing........

North side propagating house's 157

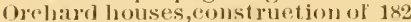

())

Jutsicle shatling............ 7t

overlieat piping.............. 108

Over vs. under beneh piping... 103

Paint bulb................. 64

Painting aud shacling........ 85

Paradigm patent glizing...... 47

Pejumanent sash bars......... 37

Pipe, amount and size of, for lot water................ 104

pipe, amolut amel size of, for .

I'ipes, slope of...............

ripes and piping for hot waller 97 lipes and piping for steam ... 124

liping, arrangement of, for hot

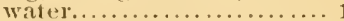

$P$ iping, allangement of, for steam ................... $12 t$

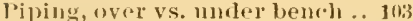

J'its, lousenemt .............. 204

I'its, colel.................. 16.5

I'itch, the optimum......... 51

I'iteli of tlie roof ............ 49

I'lan for pommereial establishment ................... 141

Jlales and gutters ............ 29

l'oints and brads, glazing......

Polmaise system of glazing ... 137

l'ortalile comservalories........ 201

J'ortalile frames.............. tifo

Portable roof ................ 35

Post.s and brices, irom ......... $4: 3$

Posts and sills, ilon.......... 32

Polting room, arrangemenl of. 22

Propagating case............. 158

Propilgating houses, eonstrue-

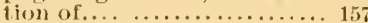

Purlin, gas pipe........... 42
Purlins and rafters, iron..... 40

['utty aur] its applieatiou....... 59

F'uty luulbs and maclines .... 64

Rafters and purlius, irou...... 40

Refraetion of liglit by glass... 50 50

liephimliug greenlmuses....... 87

Riclgis and tulvow livuses...... 11

lidge, size anul formu of........ 38

licefs, comstruction) of ......... 33

Roofs, detilis for............

lisofs, pitel of ............... 49

Rose houses, benr.luss for ...... 140

Rose lumses, coustruciou of... 142

Rose liousas, eost of........... 149

Sash, ventilatilig............ 68

Sasl bars, forms ol ........... 34

Sash bars, melallie........... 45

Shating greenhouses......... 88

Short. span to tlue south........ 55

Shmt.ters and mats ........... 161

Side-hill houses.............. 14

Sills and posts, 1 ron............. 32

Size and amount of pipe for liot water..................... 104

Size and amount of pipe for

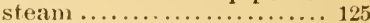

Size of glass .................... 57

Slate for benches............. 84

Slope of pipes.............. 99

Solid beds .................. 84

Spall root lumses.............. 6

"Stauclard" velitilating appa-

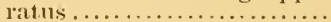

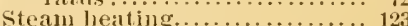

Siteam vs. luof waler .......... 129

Sitove lomser................ 17t

Strip, filss(')'s glazing........ 65

Three-quarter span houses.... 16

Tile for benulues............. 8

Valves and ('xpansim tank .... 112

Ventilating machine, al cheap.. T4

Veutilating machine, "Challenge" ................. 74

Ventilating machine, "New Depatrule, ............. 72

Ventilating machine, "Standard",

Yentilating sluafting..........

Ventilators .................. 67

Veranda conservatory....... 196

Walls for gropellionses......... 24

Watcr belleli for propagating houses................... 158

Woolen walls, constrietion of 27

Work room, arrangement of... 22

\section{PHOPERTY LIBRARY
N. C. State College}

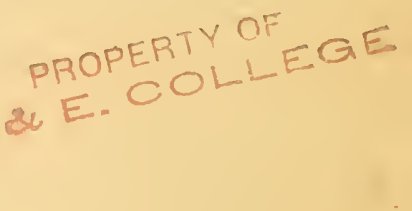


SENT FREE; ON APPLICATION.

\section{DESCRIPTIVE CATALOGUE} - $\mathrm{OF}-$

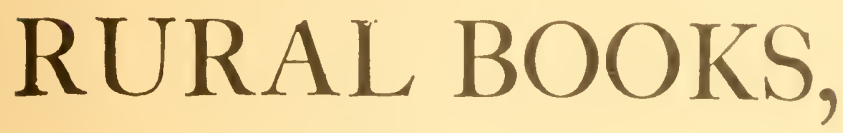

CONTAINING 116 8vo. PAGES,

PROFUSELT ILLT'STRATED, AND GIVING FULL IDECRIPTIONS OP Nearle 600 Wollis oN THe Following SUBJects.

Farm and Garden,

Fruits, Flowers, Etc.

Cattle, Sheep, and Swine,

Dogs, Horses, Riding, Etc.,

Poultry, Pigeons, and Bees, Angling and Fishing,

Boating, Canoeing, and Sailing,

Field Sports and Natural History,

Hunting, Shooting, Etc.,

Architecture and Building,

Landscape Gardening,

Household and Miscellaneous.

PUBLISHERS AND IMPORTERS:

\section{ORANGE JUDD COMPANY, 52 \& 54 Lafayette Place, New York.}

Books will be Forwarded, postpaid, on receipt of Price. 


\section{Mushrooms: How to Grow Them.}

Any one who has an ordinary house cellar, woodshed or barn, can grow Jushrooms. This is the most practical work on the subject ever written, and the only book on growing Mushrooms published in America. The anthor describes how he grows Mushrooms, and how they are grown for profit by the leading market gardeners, and for home use by the most successful private growers. Engravings drawn from nature expressly for this work. By Wm. Falconer. Cloth. rice, postpaicl.

\section{Land Draining.}

A Handbook for Farmers on the Principles and Practice of Draln. ing, by Manly Miles, giving the results of his extended experience in laying tile drains. The directions for the laying out and the construction of tile drains will enable the farmer to avoid the errors of imperfect construction, and the disappointment that must necessarily follow. This manual for practical farmers will also be found convenient for references in regard to many questions that may arise in crop growing, aside from the special subjects of drainage of which it treats. Cloth, $12 \mathrm{mo}$.

1.00

\section{Allen's New American Farm Book.}

The very best work on the subject; comprising all that can be condensed into an available volume. Originally by Richard L. Allen. Revised and greatly enlarged by Lewis F. Allen. Cloth, 12mo. 2.50

\section{Henderson's Gardening for Profit.}

By Peter IIenderson. The standard work on Market and Family Gardening. Thesucessful experience of the anthor for more than thirty years, and his willingness to tell, as he does in this work, the secret of his success for the benefit of others, enables him to give most valuable information. The book is profusely illustrater. Cloth, 12mo.

2.00

\section{Henderson's Gardening for Pleasure.}

A guide to the amateur in the fruit, vegetable and flower garden, with full deseriptions for the greenhouse, conservatory and window garden. It meets the wants of all classes in country, eity and village who keep a garden for their own enjoyment rather than for the sale of products. By Peter Henderson. Finely Hlustrated. Cloth, $12 m o$.

2.00

\section{Johnson's How Crops Grow.}

New Edition. A Treatise on the Chemical Composition, Structure and Life of the Plant. Revised Edition. This book is a guide to the knowledge of agricultural plants, their composition, their structure and modes of ilevelopment and growth; of the complex organizations of plants, and the nse of the parts; the gemination of seeds, and the food of plants obtained both from the air and the soil. The book is a valuable one to all real students of agriculture. With numerous illustrations and tables of analysis. By Prof. Samue1 W. Johnson of Yale College. Cloth, $12 \mathrm{mo}$. 


\section{Johnson's How Crops Feed.}

A Treatise on the Atmospluere and tho Soll, as related In the Nutrition of Agriulunal l'ants. This volume-the rempanion and

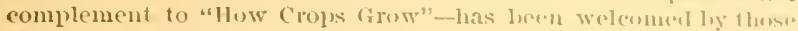
who appreeiate the sejentific asperts of agrieulture. 1llustraterl. By Prof. Sammel W. Jolnsun. Cloth, 12no.

\section{Market Gardening and Farm Notes.}

By limmet Landreth. Jxperienees and Observations for loth North and South, of interest to the Amateur fardener, Truelier amel Farmer. A novel featme of the book is the "alendar of farm and garden operations for each month of the year; the chapters in fertilizers, transplanting, succession and rotatiun of (r)pes, flws paeking, shipping and marketing of vegetables, will be especially useful to market gardencrs. Cloth, 12mo.

\section{Forest Planting.}

A Treatise on the Care of Woodlands anct the Restoration of tho Demuded Timber-Lancls on l'lains am Mountaius. liy H. Nirholas Jarehow, LL. D. The autlur has fully deseribed those Europan methods whieh liave proved fobe most useful in maintaining the superb forests of the old worla. This experince has been alapted to the different climates and trees of 1 merica, full instructions being given for forest planting on our various kinds of soil and subsoil, whether on mountain or valley. Illustrated, $12 \mathrm{mo}$.

\section{Harris' Talks on Manures.}

By Joseph Harris, M. S., author of "Walks and Talks on the Farm," "Harris on the Pig," efe. Revised and enlarged hy the author. A series of familiar aud putetical talks betwern the author and the Deaeon, the Doetor, aml other neighbors, on the whole subjert of manures and fertilizers : including a chapter espeeially written for it, by Sir John Bennet Lawes of Fothansted, England. Cloth, 12110 .

1.75

\section{Truck Farming at the South.}

A work which gives the experience of a successful grower of veretables or "trnek" for Norther"n matkets. Essential to any one who contemplates entering this promising field of Agrieulture. liy 1. Oemler of Georgit. Illustrated, eloth, $12 m 0$.

\section{Sweet Potato Culture.}

Giving full instruetions from starting the plants to harvesting and storing the erop. With a chapter wn the clanese vam. liy dames Fitz, Keswich, Va., author of "Southern Apple and Peach Culture." Cloth, 12mo.

\section{Heinrich's Window Flower Garden.}

The author is a practical florist, and this enterprising volume cm-

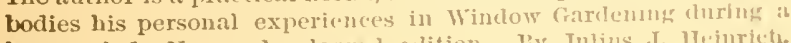
long period. New and enlargal edition. Ly Julius J. Heimrict. Fully illustrated. Clotl1, 1:mo, 


\section{Greenhouse Construction.}

By Prof. L. R.Taft. A eomplete treatise on Greenhouse structures and arrangements of the various forms and styles of Plant Houses for professional florists as well as amatenrs. All the best and most approved struetures are so fully and clearly deseribed that anyone who desires to build a Greenhouse will have no diffieulty in determining the kind best suited to his purpose. The modern and most sucessful methods of lieating and ventilating are fully treated upon. Special chapters are devoted to houses used for the growing of one kind of plants exclusively. The construetion of hotbeds and frames receives appropriate attention. Over one lundred excellent illustrations, specially engraved for this work, make every point elear to the reader and add considerably to the artistic appearanee of the book. Clotl, $12 \mathrm{mo}$.

1.50

\section{Bulbs and Tuberous-Rooted Plants.}

By C. L. Allen. A complete treatise on the History, Deseription, Methods of Propagation and full Directions for the sueeessful eulture of Julbs in the garden, Dwelling and Greenlouse. As generally treated, bulbs are an expensive luxury, while, when properly managed, they afford the greatest amount of pleasure at the least cost. The author of this book lias for many years made bulb grow. ing a speeialty, and is a reeognized authority on their enlivation and management. The illustrations which embellish this work have been drawn from nature, and have been engraved espeeially for this book. The enltural directions are plainly stated, practical and to the point. Clotli, $12 m o$.

2.00

\section{Henderson's Practical Floriculture.}

By Peter Tenderson. A guide to the suceessful propagation and cultivation of florists' plants. The work is not one for florists and gardeners only, lut the amateur's wants are constantly kept in mind, and we have a very complete treatise on the cultivation of flowers nnder glass, or in the open air, snited to those who grow flowers for pleasure as well as those who make them a matter of trade. Beautifully illustrated. New and enlarged edition. Cloth, $12 \mathrm{mo}$.

\section{Long's Ornamental Gardening for Americans.}

A Treatise on Beantifying Homes, Rural Distriets and Cemeteries. A plain and practieal work at a modelate price, with nmmerous illustrations and instrutions so plain that they may be readily followed. by Elias A. Long, Landscape Architect. lllustrated, Cloth, 12 mo.

\section{The Propagation of Plants.}

By Andrew S. Fuller. Illnstrated with numerous engravings. An eminently practical and useful work. Jeseribing the proeess of hybridizing and crossing species and varieties, and also the many different modes by which cultivated plants may be propagated and multiplied. Cloth, 12mo, 


\section{Parsons on the Rose.}

By Samuel B. I'arsons. A treatise on the propagatlon, culturo nncl histury of the rose. New and revised calition. In his work upm the rose, IIr. Parsons has gatlered up the curious legends concerble ing the flower, and gives us an iclea of the esteen in which it was

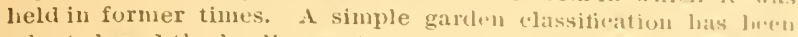
adopted, and the leating varieties under each elass cumunratal and brietly deseribed. The elsapters on multiplication, (nhlivation and training are very full, and the work is altogether onc of the most complete before tlie public. Illustrated. Cloth, 12mo. 1.0u

\section{Henderson's Handbook of Plants.}

This new edition eomprises about fifty per eent. more genera than the former one, and embraces the botanieal name, derivation, matural orter, ete, together with a short history of the dirferut genera, coneise instructions for their propagation and enlture, and all the leading locil or eommon Englislı names, together with at comprehensive glossary of lBotanical and Technical terms. I'lain instructions are also given for the cultivation of the principal vegetables, fruits and flowers. Cloth, large Svo.

4.00

\section{Barry's Fruit Garden.}

By P. Barry. A standard work on Fruit and Frut Trees; 1lie antlior having had over thirty years' practieal experience at the heal of one of the largest nurseries in this comntry. New edition revised up to date. Invaluable to all fruit growers. Illustrated. Cloth, 12 mo.

2.00

\section{Fulton's Peach Culture.}

This is the only practical guide to Peach Culture on the Delaware Peninsula, and is the best work upon the subject of peach growing for those who would be successful in that eulture in any part of the eountry. It has been thorougluly revised and a large jortion of it rewitten, by Hon. J. Alexander Fultum, the author, bringing it down to clate. Cloth, 12 mo.

\section{Strawberry Culturist.}

By Andrew S. Fuller. Containing the Hlstory, Sexuality, Ficld and Garden Culture of Strawberries, foreing or pot eulure, low 10 grow from seed, hybridizing, and all inforuation necessary to enable everybody to raise their own strawberries, together with it description of new varieties and a list of the best of the old sorts. Fully illustrated. Flexible eloth, 1'mo.

\section{Fuller's Small Fruit Culturist.}

By Andrew S. Fuller. Rewritten, enlargerl, and hrought fully" up to the present time. The look covers lhe whole gromul of projagatise Small Fruits, their culture, varieties, paeking for market, che. It is very finely and thoroughly illustrated, ancl makes an acluijablo companion to "The Grape Culturist," by the same rell known author. 


\section{Fuller's Grape Culturist.}

By A. S. Fuller. This is one of the very best of works on the Culture of the Hardy Grapes, with full direetions for all departments of propagation, culture, etc., with 150 excellent engravings, illustrating planting, training, grafting, ete. Cloth, $12 \mathrm{mo}$.

\section{Quinn's Pear Culture for Profit.}

Teaching How to Raise Pears intelligently, and with the best results, how to find ont the eliaraeter of the soil, the best methods of preparing it, the hest varieties to seleet moler existing eonditions, the best modes of planting, pruning, fertilizing, grafting, and utilizing the ground before the trees eome into bearing, and finally of gathering and packing for market. Illustrated. By I'. T. Quinn, practical lorticulturist. Cloth, 12mo

\section{Husmann's American Grape Growing and Wine-Making.}

By George Husmann of Talcoa vineyards, Napa, California. New and enlarged edition. With contributions from well know grapegrowers, giving a wide range of experience. The author of this book is a recognized authority on the subjeet. Cloth, 12mo. $\quad 1.50$

\section{White's Cranberry Culture.}

Contents:-Natural History.-History of Cultivation.-Choiee of Location.-Preparing the Gromd.--Planting the Vines.-Management of Meallows.-Flooding.-Enemies and Difficulties Overcome. -Picking.-Feeping.-Profit and Loss.-Letters from Praetieal Growers.-Insects Injurious to the Cramberry. By Josepl J. White, a practlcal grower. Illustrated. Cloth, 12mo. New and revised edition.

\section{Fuller's Practical Forestey.}

A Treatise on the Propagation, Planting and Cultivation, with a deseription and the botanieal and proper names of all the indigenous trees of the United States, botls Evergreen and Deeiduous, with Notes on a larg'e number of the most valuable Exotic Species. By Andrew S. Fuller, autlor of "Grape Cułturist," "Small Fruit CuIturist," ete.

\section{Stewart's Irrigation for the Farm, Garden and Orchard.}

Thls work is offered to those Ameriean Farmers and other cultivators of the soil who, from painful experience, can reacily appreciate the losses whieh result from the scareity of water at eritical periods. liy Henry Stewart. Fully illustrated. Cloth, 12mo. 1.50

\section{Quinn's Money in the Garden.}

By P. T. Quiun. The author gives in a plain, practical style, instructions on three distinct, althongh elosely conneeted branehes of gardening-the kitchen garden, narket garden, and field euIture, from sueeessful practical experience for a term of years. Illustrated. Cloth, $12 \mathrm{mo}$. 









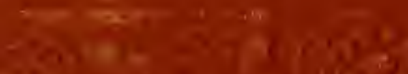

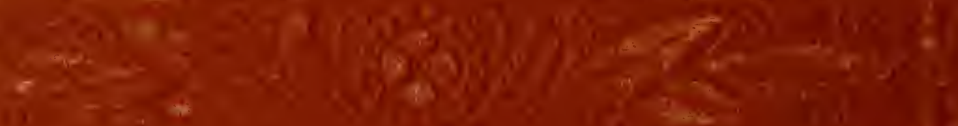

$1,-2.4$

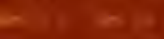

$\cos$

1

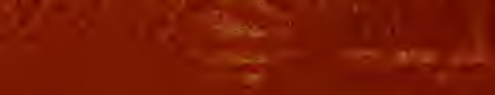
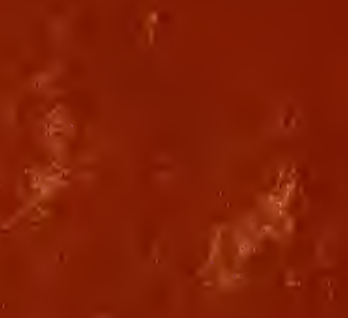

$2+2$

$\frac{1}{3}$

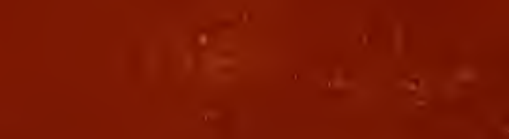

$c$

i.
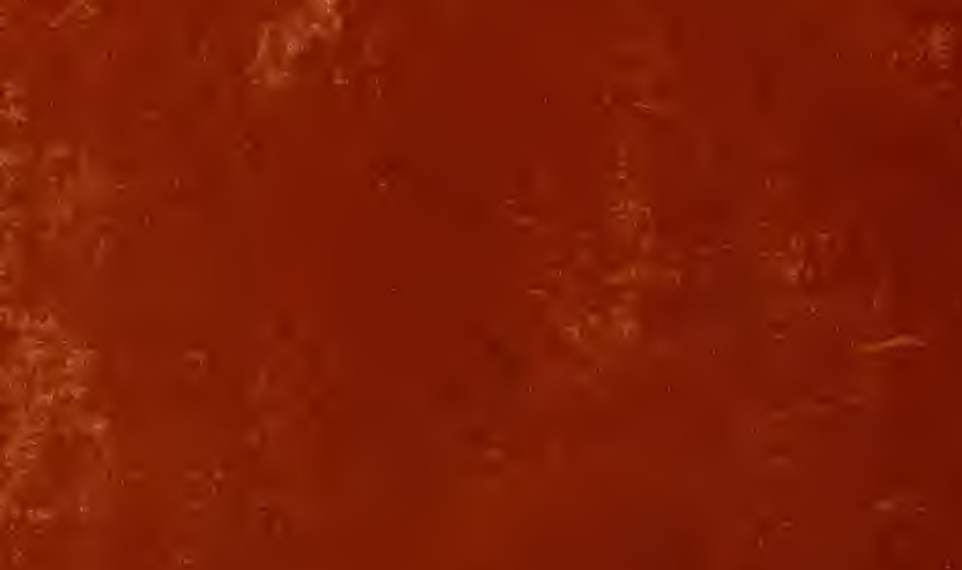

$\frac{3}{3}$

$-$

7

$=0$

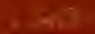

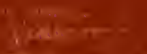

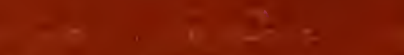

$2 \pm 0$

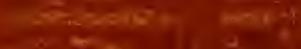

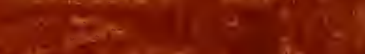

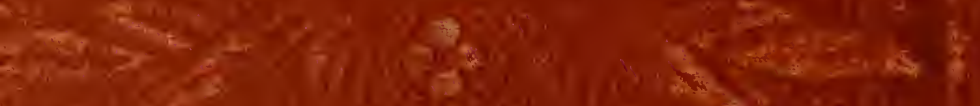

